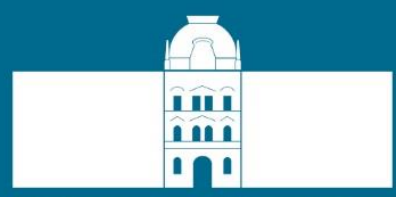

Univerza v Mariboru

\title{
Poslovno komuniciranje
}

Avtor:

\section{dr. Marko Ferjan}




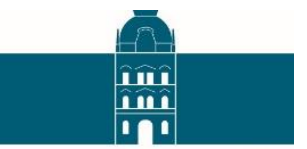

Univerzitetna založba

Univerze v Mariboru 


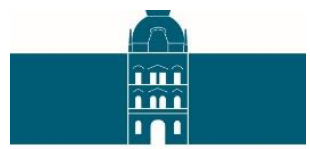

Univerzitetna založba

Univerze v Mariboru

\section{Poslovno komuniciranje}

Avtor:

dr. Marko Ferjan

September 2017 
Naslov: Poslovno komuniciranje

Title: Business communication

Avtor: red. prof. dr. Marko Ferjan (Univerza v Mariboru, Fakulteta za organizacijske vede)

Strokovna recenzija:

\section{Jezikovna recenzija \\ Tehnična urednika:}

red. prof. Vlado Dimovski, (Univerza v Ljubljani, Ekonomska fakulteta) red. prof. dr. Eva Jereb (Univerza v Mariboru, Fakulteta za organizacijske vede) izred. prof. dr. Janez Stare (Univerza v Ljubljani, Fakulteta za upravo)

\section{Doroteja Piber}

Jan Perša (Univerzitetna založba Univerze v Mariboru)

Armin Turanović (Univerzitetna založba Univerze v Mariboru)

Oblikovanje ovitka: Jan Perša (Univerzitetna založba Univerze v Mariboru)

\section{Grafične priloge: Avtor}

\section{Izdajateljica:}

Univerza v Mariboru, Fakulteta za organizacijske vede

Kidričeva cesta $55 \mathrm{a}, 4000 \mathrm{Kranj}$, Slovenija

tel. +38642374200, faks +38642374299

http://www.fov.um.si, dekanat@fov.uni-mb.si

\section{Založnik:}

Univerzitetna založba Univerze v Mariboru

Slomškov trg 15, 2000 Maribor, Slovenija

tel. +38622504242 , faks +38622523245

http://press.um.si, zalozba@um.si

\section{Dostopno na: http://press.um.si/index.php/ump/catalog/book/269 \\ Izid: September 2017}

\section{(C) Univerzitetna založba Univerze v Mariboru}

Vse pravice pridržane. Brez pisnega dovoljenja založnika je prepovedano reproduciranje, distribuiranje, predelava ali druga uporaba tega dela ali njegovih delov v kakršnemkoli obsegu ali postopku, vključno $s$ fotokopiranjem, tiskanjem ali shranjevanjem v elektronski obliki.

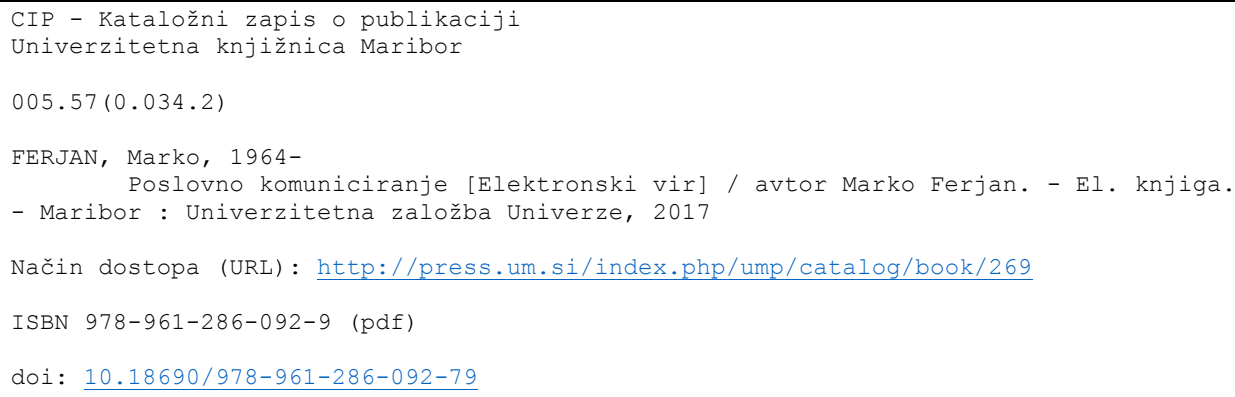

ISBN: $\quad$ 978-961-286-092-9

DOI: https://doi.org/10.18690/978-961-286-092-9

Cena: Brezplačen izvod

Odgovorna oseba založnika: red. prof. dr. Igor Tičar, rektor Univerze v Mariboru 


\section{Poslovno komuniciranje}

\section{MARKO FERJAN}

Povzetek Človeško telo s svojimi čutili vsako minuto zazna okoli 10.000 senzoričnih zaznav. Zaznave imajo različne pojavne oblike in so: vizualne zaznave, zaznave zvoka, vonja, temperature, okusa, bolečine in prostorskega položaja telesa (ravnotežja). Na osnovi zaznav iz fizičnega sveta v človekovih možganih nastanejo percepcije, kognicije in čustva. Pri sprejemanju in oddajanju sporočil sodeluje človekovo telo kot celota.

Knjiga izhaja iz konceptov percepcijske organizacije. Tako, kot pri človekovem komuniciranju sodeluje telo kot celota, je tudi komuniciranje percepcijske organizacije treba obravnavati kot celoto. Vsebina komuniciranja se $\mathrm{z}$ vidika organizacije nanaša na vse atribute identitete organizacije. $Z$ vidika okolja pa se nanaša na norme, potrebe, pričakovanja in želje do organizacije. Pojavne oblike komuniciranja organizacije $\mathrm{z}$ okoljem so: interpersonalno komuniciranje managementa in zaposlenih $\mathrm{z}$ okoljem, komuniciranje organizacije preko spletnih kanalov, marketinško komuniciranje, odnosi z javnostmi, odnosi z vlagatelji, pogajanja, lobiranje in krizno komuniciranje.

Ključne besede: $\cdot$ poslovno komuniciranje $\cdot$ organizacija $\cdot$ image $•$ identiteta $\bullet$ percepcija $\bullet$

NASLOV AVtROJA: dr. Marko Ferjan, redni profesor, Univerza v Mariboru, Fakulteta za organizacijske vede, Kidričeva cesta 55a, 4000 Kranj, Slovenija, e-pošta: marko.ferjan@ fov.unimb.si. 


\title{
Business Communication
}

\author{
MARKO FERJAN
}

\begin{abstract}
Who are we as an organization? « Organizational identity is the answer to the question. This book explores norms, needs, expectations and wishes from environment and the behaviours that bring solutions in the world of constant changes, high competition and need for constant development. From the beginning of modern buissness, the key for survival has always been communication, and it still is today.
\end{abstract}

Communication is a process of exchanging verbal and non verbal messages. As a human body reacts to stimulations it gets thru feeling, seeing, smelling, tasting and hearing, so the organisation shoud have an awareness of the internal and external environment. After detections from the physical world, the human brain develops perceptions, cognitions and emotions. In this process, the human body participates as a whole.

Similarly, the communication of an organization should be considered as a whole. The content of business communication refers to all the attributes of the organization's identity.

The forms of business communication are: interpersonal communication, marketing communication, public relations, investor relations, negotiations, lobbying and crisis communication; in context of organizational identity.

Keywords: • business communication $\bullet$ organization $\bullet$ image $\bullet$ identity $\bullet$ perception $\bullet$

CorRespondence AdDress: Marko Ferjan, Ph.D., Full Professor, University of Maribor, Faculty of Organizational Sciences, Kidričeva cesta 55a, 4000 Kranj, Slovenia, e-mail: marko.ferjan@fov.uni-mb.si. 


\section{Kazalo}

PREDGOVOR

TEORETIČNE OSNOVE KOMUNICIRANJA ................................................. 5

TEORETIČNI SISTEMI KOMUNICIRANJA …................................................ 7

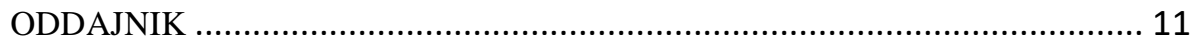

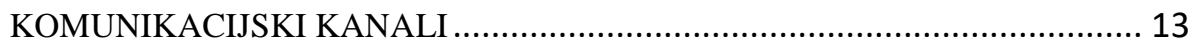

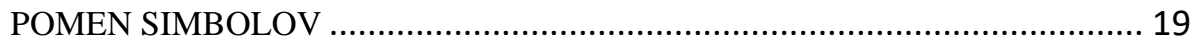

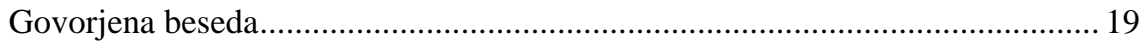

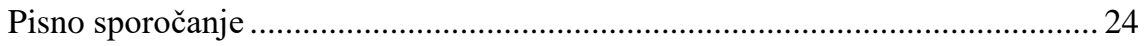

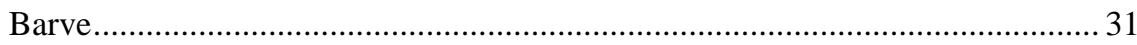

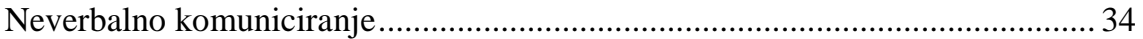

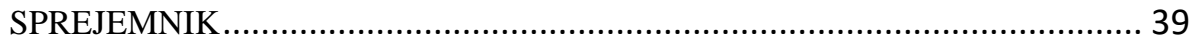

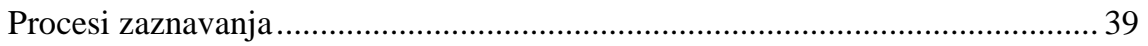

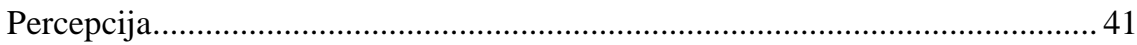

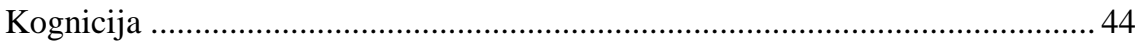

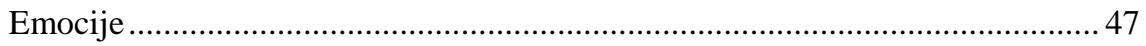

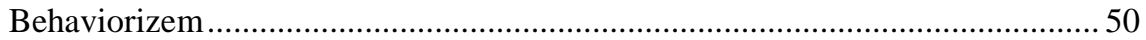

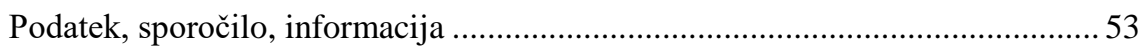

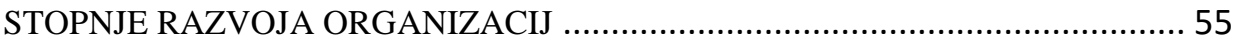

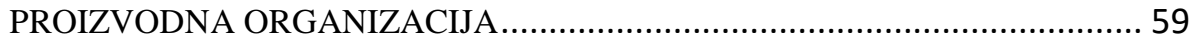

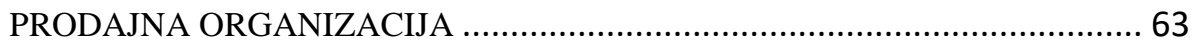

TRŽENJSKA (MARKETINŠKA) ORGANIZACIJA .........................................67

DRUŽBENO ODGOVORNA ORGANIZACIJA ……................................... 75

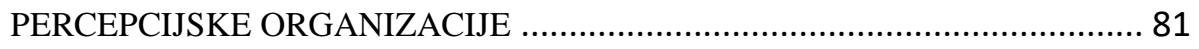

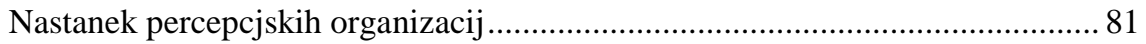


ii $\begin{aligned} & \text { PosLOvNO KOMUNICIRANJE } \\ & \text { Kazalo }\end{aligned}$

Identiteta organizacije ........................................................................ 83

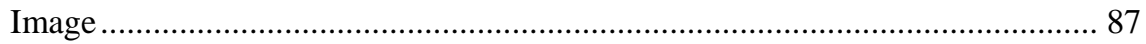

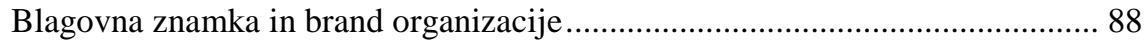

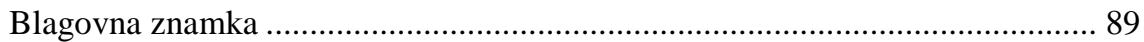

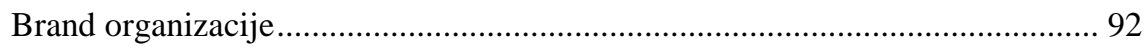

KOMUNICIRANJE PERCEPCIJSKIH ORGANIZACIJ .................................. 95

ZAPOSLENI IN MANAGEMENT ....................................................... 105

POSLOVNO OBLAČENJE .......................................................... 111

Pomen vizualne zaznave............................................................................ 111

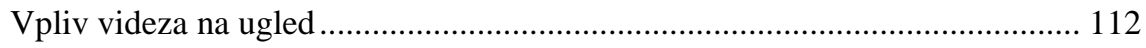

Pravila poslovnega oblačenja ................................................................ 114

KOMPETENCE ZAPOSLENIH ................................................. 123

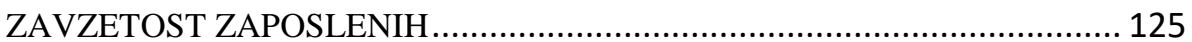

NOTRANJA KOHEZIVNOST ....................................................... 127

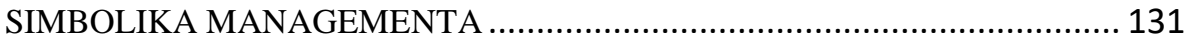

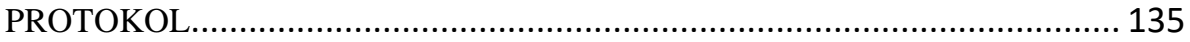

SPLETNO KOMUNICIRANJE ORGANIZACIJ..................................... 137

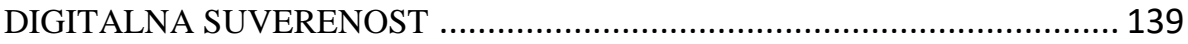

ODLOČITEV O POSREDOVANJU VSEBINE ................................... 143

KANAL, VSEBINA, FORMAT .................................................. 145

OBJAVA ALI ODDAJA .............................................................. 149

ODZIVANJE NA POVRATNE INFORMACIJE .................................... 151

MARKETINŠKO KOMUNICIRANJE .................................................. 153

MARKETINŠKI KOMUNIKACIJSKI SISTEM .................................... 155

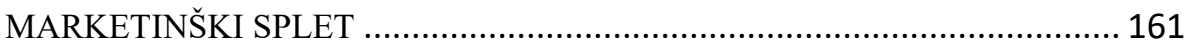

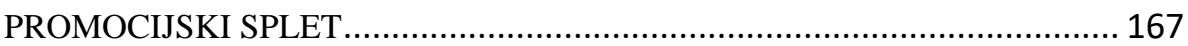


OGLAŠEVANJE 171

DIGITALNI MARKETING 179

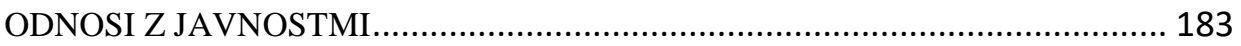

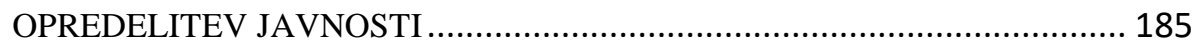

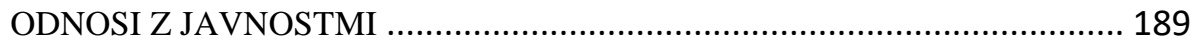

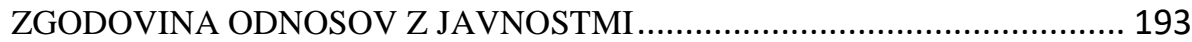

MODELI IN STRATEGIJE ODNOSOV Z JAVNOSTMI.............................. 195

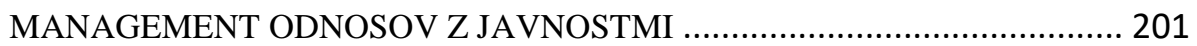

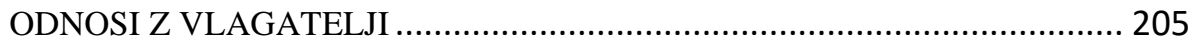

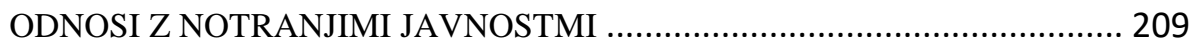

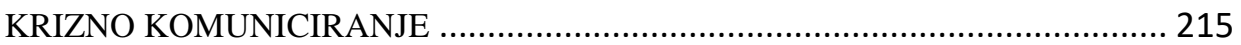

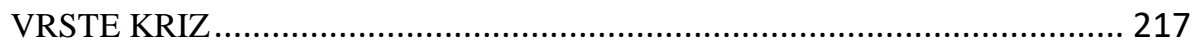

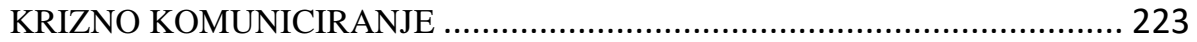

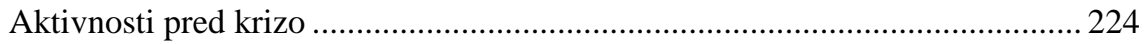

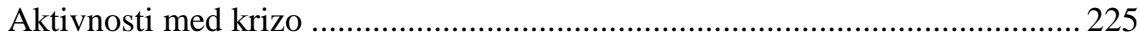

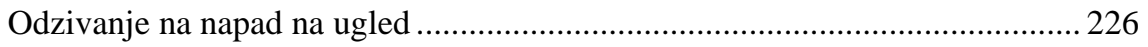

Komuniciranje ob nesrečah.............................................................................. 230

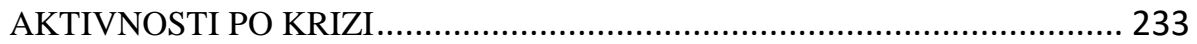

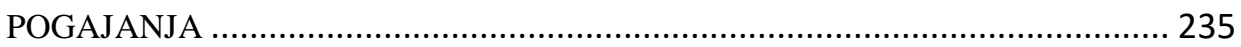

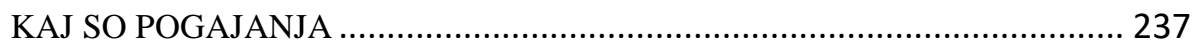

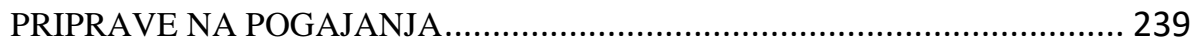

Spoznavanje konteksta in strukture problema …………................................. 239

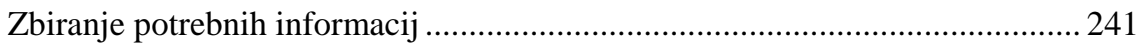

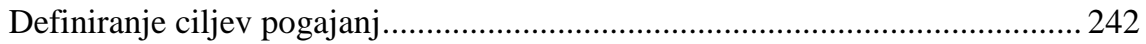

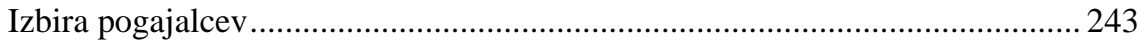

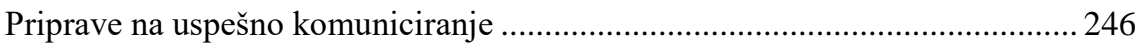


iv $\mid \begin{aligned} & \text { POSLOVNO KOMUNICIRANJE } \\ & \text { Kazalo }\end{aligned}$

Načrtovanje poteka pogajanj ................................................................... 246

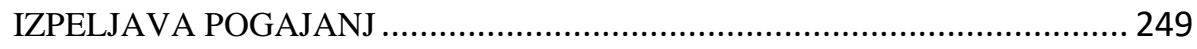

POGAJALSKE TAKTIKE .......................................................... 251

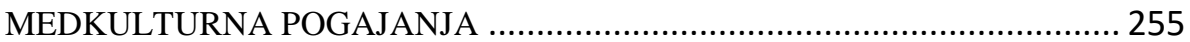

LAŽNA POGAJANJA ................................................................. 257

ZAKLJUČEK POGAJANJ .............................................................. 259

LOBIRANJE ......................................................................... 261

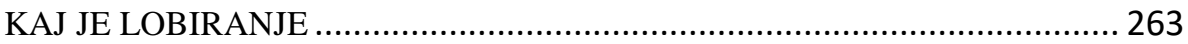

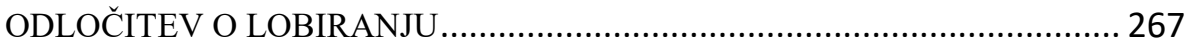

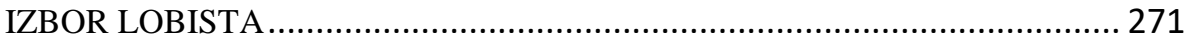

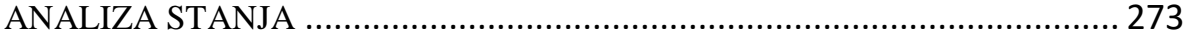

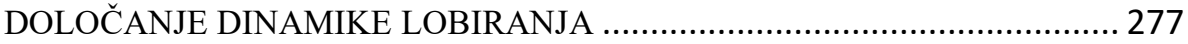

IZBOR METOD LOBIRANJA ..................................................... 279

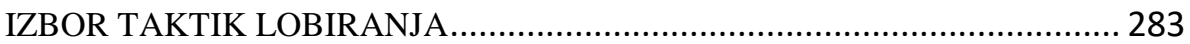

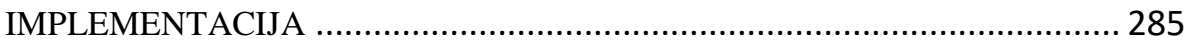

VREDNOTENJE REZULTATOV .................................................... 287

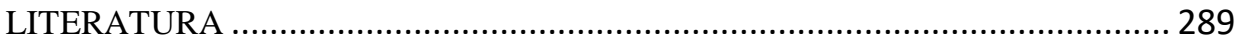

ELEKTRONSKI VIRI..................................................................... 303

STROKOVNE RECENZIJE ............................................................ 307

STROKOVNA RECENZIJA V. DIMOVSKI ............................................. 309

STROKOVNA RECENZIJA E. JEREB .................................................... 313

STROKOVNA RECENZIJA J. STARE ............................................... 315 


\section{PREDGOVOR}

Človeško telo s svojimi čutili vsako minuto zazna okoli 10.000 senzoričnih zaznav. Zaznave imajo različne pojavne oblike in so: vizualne zaznave, zaznave zvoka, vonja, temperature, okusa, bolečine in prostorskega položaja telesa (ravnotežja). Na osnovi zaznav iz fizičnega sveta $v$ človekovih možganih nastanejo percepcije, kognicije in čustva. Percepcije so mentalne podobe realnosti kot rezultat stimulacije čutil in živčevja. Odziv možganov in telesa na zaznave so tudi čustva in razpoloženja. Kognicija pa je proces spoznavanja, v katerega je poleg fizičnega vključeno tudi socialno okolje. Človekovo obnašanje je odvisno od notranjih reprezentacij posameznika, ki so: percepcija, kognicija, spomin in razmišljanje ter od vplivov zunanjega sveta. Človek pa simbole tudi oddaja. Skozi evolucijo je razvil sposobnost komuniciranja z drugimi. Komuniciranju je fenomen, pri katerem sodeluje človekovo telo kot celota. Prav sposobnost komuniciranja je tista, ki je ljudem omogočila, da so si kot člani človeških skupnosti skozi vso zgodovino med seboj delili delo.

Skozi evolucijo so stopnje tehnološkega razvoje prišle od enostavnih ročnih del do stopnje, ko avtomatske naprave same opravljajo proizvodne procese. $\mathrm{V}$ razvitih državah je v proizvodnji zaposlena manj kot ena tretjina delovno aktivne populacije, govorimo pa o »Industriji 4.0«. Vzporedno s procesi razvoja se je spreminjala tudi organizacija. Stopnje razvoja organizacije so: proizvodna, prodajna, trženjska, družbeno odgovorna in percepcijska organizacija. Pri razvrščanju gre za vprašanje, kateremu atributu organizacija namenja prevladujoč pomen.

Proizvodna organizacija prevladujoč pomen namenja proizvodnji dobrin.

Prodajna organizacija se osredotoča na prodajo, ključni atribut pa je izdelek ali storitev.

Bistvo koncepta marketinške organizacije je v zadovoljenju potreb kupcev. Organizacija mora storiti vse, da bodo kupci zadovoljni.

Družbena odgovornost pomeni, da podjetja prostovoljno prevzemajo odgovornost za različna družbena, gospodarska, ekološka in kulturna vprašanja.

Za percepcijsko organizaciji je pomemben odnos do ljudi v širši skupnosti. Percepcijska organizacija je organizacija, ki pri izvrševanju namena svojega obstoja sistematično upravlja s svojo identiteto. Identiteta organizacije je vse tisto, kar organizacija v resnici je. Dejanska identiteta organizacije odraža sedanje vrednote organizacije in ima številne elemente: lastništvo oziroma ustanoviteljstvo organizacije, management, stil vodenja, organizacijsko strukturo, izvajanje poslovnih funkcij, kakovost in ostali pomembni atributi proizvodov in storitev ter poslovne rezultate. 
Knjiga izhaja iz konceptov percepcijske organizacije. Tako, kot pri človekovem komuniciranju sodeluje telo kot celota, je tudi komuniciranje percepcijske organizacije treba obravnavati kot celoto. Namen, vsebine, uporabljeni kanali, dinamika in usmerjenost komuniciranja percepcijskih organizacij izhaja iz poslanstva organizacije in namena obstoja organizacije. Poslanstvo organizacije mora odgovoriti na vprašanja: kaj je dejavnost, kdo so partnerji, kaj se ceni, kdo so partnerji ipd. Namen obstoja percepcijske organizacije je kompleksen. Vključuje poslovni izid, rezultate, povezane z odjemalci, rezultate povezane $\mathrm{z}$ zaposlenimi in rezultate povezane $\mathrm{z}$ okoljem.

Za udejanjanje poslanstva in izvrševanje namena obstoja katerekoli organizacije so potrebne neprestane interakcije $\mathrm{z}$ okoljem. Naloga funkcije komuniciranja je, da ob upoštevanju namena obstoja organizacije in norm okolja zagotovi kontinuirano in uravnoteženo interakcijo med organizacijo in okoljem $\mathrm{z}$ namenom medsebojne uskladitve.

Objekt, na katerega se komuniciranje percepcijske organizacije nanaša, je identiteta organizacije.

Vsebina komuniciranja se $\mathrm{z}$ vidika organizacije nanaša na vse atribute identitete organizacije. $Z$ vidika okolja pa se nanaša na norme, potrebe, pričakovanja in želje do organizacije.

Proces komuniciranja percepcijske organizacije je dvosmeren, kar pomeni, da so naloge komuniciranja: pošiljanje sporočil o identiteti organizacije $\mathrm{v}$ okolje, sprejemanje sporočil o organizaciji iz okolja, ter usklajevanje atributov identitete organizacije.

Komuniciranje organizacije z okoljem poteka: pred dogodki, med potekom dogodkov in po dogodkih, ki so pomembni tako za organizacijo kot za okolje.

Pojavne oblike komuniciranja organizacije z okoljem so:

- interpersonalno komuniciranje managementa in zaposlenih z okoljem;

- komuniciranje organizacije preko spletnih kanalov;

- marketinško komuniciranje;

- odnosi z javnostmi;

- odnosi z vlagatelji;

- pogajanja;

- lobiranje;

- krizno komuniciranje.

Naštetih pojavnih oblik ni mogoče obravnavati parcialno, tako kot je bilo v preteklosti. Treba jih je obravnavati kot enoten proces dvosmernega komuniciranja organizacije $\mathrm{z}$ okoljem.

V tej knjigi so zbrana spoznanja dolgoletnih raziskovanj na področju poslovnega komuniciranja in osebne izkušnje ter spoznanja, da katerih sem prišel. 
Hvaležen sem neštetim neimenovanim entuziastom iz vsega sveta, ki so s svojim znanstvenim preučevanjem komuniciranja in strokovnim delom na področju informatike sedanji generaciji ljudi omogočili privilegij, da imamo vsi dostop do množice impresivnih znanstvenih spoznanj.

Posebej se zahvaljujem Vesni, ki mi je bila pri pisanju knjige v veliko pomoč.

Knjigo posvečam Maruši in Karmen. 

PosLOVNO KOMUNICIRANJE

M. Ferjan 



\section{TEORETIČNI SISTEMI KOMUNICIRANJA}

Komuniciranje je proces oddajanja, prenosa in zaznavanja vzajemno sprejetih simbolov. Sprejetost simbolov v skupini pomeni enako razumevanje simbola pri vsakem udeležencu komuniciranja. Pojem "komunicirati" je zelo širok, saj zajema številne, med seboj zelo različne pojavne oblike komuniciranja: od običajnega vsakodnevnega pogovora med ljudmi, do izmenjave podatkov med napravami. Beseda "komunicirati" izvira iz latinske besede "communicare«.

Sposobnost oddajanja različnih simbolov ter zaznavanja in razumevanja simbolov iz okolja je ena od najpomembnejših zmožnosti, ki se je skozi evolucijo razvila pri številnih živih bitjih.

Interpersonalna komunikologija je veda, ki se ukvarja s primarnim, to je neposrednim komuniciranjem med ljudmi. Komuniciranje je fenomen, ki je v evoluciji človeštva še posebej pomemben. Pri ljudeh so se skozi evolucijo razvili telesni organi, s katerimi človek oddaja različne simbole. Vzporedno so se v procesu evolucije človeka razvili tudi organi, ki omogočajo zaznave in mentalno obdelavo zaznanega. Oddajanje simbolov in zaznavanje potekata tako na zavedni, kot na nezavedni ravni. Oddajanje nekaterih simbolov je posledica delovanja vegetatitvnega živčevja. Nekatere oblike komuniciranja, npr. govor, pa niso prirojene in se jih človek $v$ procesu odraščanja mora naučiti. Komuniciranje ljudem omogoča vzpostavljanje odnosov z drugimi ljudmi in prenos družbene dediščine človeštva. Brajša (2014) pravi, da človek postane socialno bitje šele, ko razvije sposobnost zavestnega komuniciranja z drugimi ljudmi. Pravi, da se človek, preden postane »človek«, mora »roditi štirikrat«:

1. Prvo rojstvo je biološko (v ožjem pomenu besede somatsko, telesno). Telo se rodi z nedozorelimi možgani.

2. Drugo rojstvo je cerebralno. Možgani se dokončno razvijejo šele v prvem letu otrokovega življenja. Proces razvoja možganov je za človeka tipičen. Dokazano je, da je psihomotorični razvoj otroka (sedenje, prvi koraki, govorjenje, ...) odvisen od neposrednega interpersonalnega komuniciranja med otrokom in tistimi, ki ga negujejo. Interpersonalno komuniciranje je povezana tako z razvojem, kot z delovanjem možganov.

3. Tretje rojstvo je personalno (osebnostno). Otrok se osebnostno razvije med tretjim in petim letom starosti. Tudi razvoj osebnosti je povezan $\mathrm{z}$ interpersonalnim komuniciranjem

4. Četrto rojstvo je socialno (družbeno). Človek socialno dozori šele po petnajstem letu starosti. Identiteto razvijamo in udejanjamo s pomočjo nekaterih osnovnih življenjskih spretnosti: sprejemanje in dajanje, delo, sodelovanje, sprejemanje samega sebe. 
Komunikologija je veda, ki se ukvarja $\mathrm{s}$ komunikacijo občil; $\mathrm{z}$ medijskim, organizacijskim, javnim, skratka množičnim komuniciranjem.

Klasični model komuniciranja sta razvila Shannon in Weaver. Model odgovarja na pet vprašanj:

- Kdo?

- Kaj?

- Komu?

- Na kakšen način? (Oziroma kako?)

- S kakšnim učinkom?

Elementi sistema komuniciranja: so: oddajnik, sprejemnik, sporočilo in komunikacijski kanal. Enostaven sistem komuniciranja ima en oddajnik in en sprejemnik. Pri enostavnem sistemu komuniciranja še ne moremo govoriti o povratni zvezi. Da bi ugotovili učinek poslanega sporočila je potrebna povratna zveza. Ni nujno, da ima vsak sistem komuniciranja povratno zvezo. Enostaven sistem komuniciranja s povratno zvezo prikazuje slika 1.

Oddajnik je oseba ali naprava, ki oddaja sporočila.

Sprejemnik je oseba ali naprava, ki sporočilo sprejme.

Komunikacijski kanal je pot, po kateri poslano sporočilo potuje.

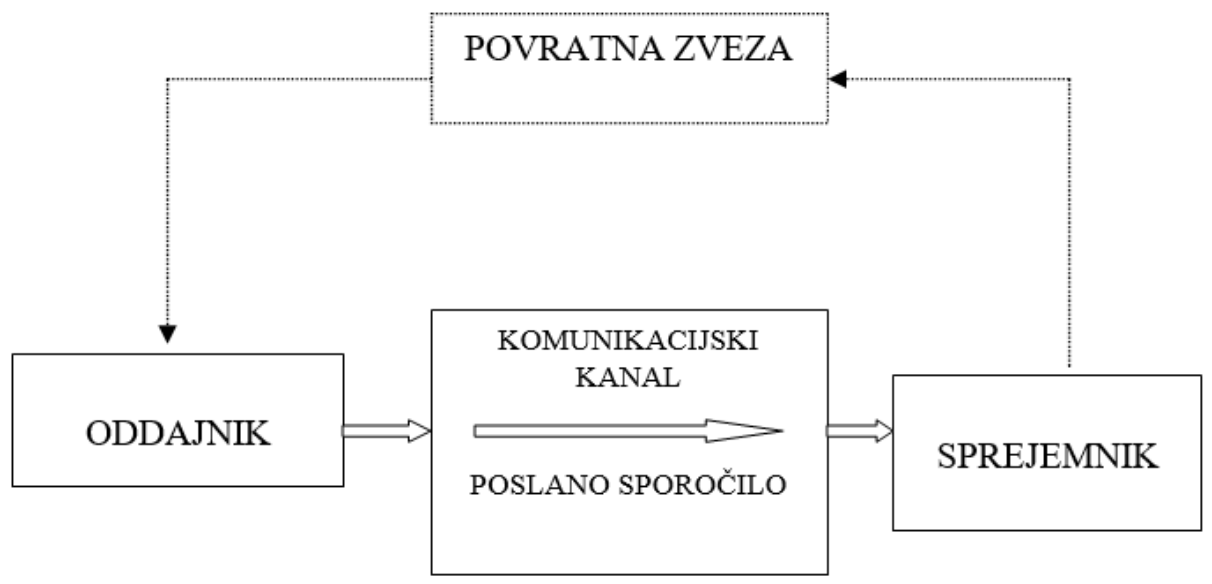

Slika 1: Sistem komuniciranja s povratno zvezo ${ }^{3}$

\footnotetext{
3 Povzeto po: Harrison, 1995. Naslov originala: Shannon, C. and Weaver W. (1948): "The
} Mathematical Theory of Communications", Urbana, University of Ilinois Press 
Pogoj, da proces komuniciranja lahko poteka je, da so prisotni vsi elementi sistema komuniciranja. Pomembno je, da so elementi prisotni v časovnem intervalu, v katerem naj bi proces komuniciranja potekal; lahko so prisotni hkrati, ali pa tudi ne. Med procesom komuniciranja namreč obstoji možnost, da komunikacijski kanal poslano sporočilo tudi shrani za določeno časovno obdobje, tako da ga sprejemnik sprejme $\mathrm{z}$ določenim časovnim zamikom.

Poznamo enosmerne in dvosmerne sisteme komuniciranja. Za enosmerne sisteme praviloma velja:

- Sprejemnik vrši zgolj funkcijo sprejema.

- Oddajnik vrši zgolj funkcijo oddaje.

- Komunikacijski kanal prenaša poslano sporočilo le v eno smer.

Pri enosmernem komuniciranju ne pride niti do medsebojnega reagiranja, niti do medsebojnega vplivanja.

Za dvosmerne sisteme komuniciranja pa velja:

- $\quad \mathrm{Na}$ obeh straneh sistema komuniciranja sta sprejemnik in oddajnik.

- Komunikacijski kanal prenaša poslana sporočila v obe smeri.

Poznamo dvosmerne sisteme komuniciranja, pri katerih na obeh straneh komunikacijskega kanala lahko hkrati potekata proces sprejema in oddaje in dvosmerne sisteme komuniciranja, pri katerih hkratna sprejem in oddaja na isti strani komunikacijskega kanala nista možna.

Poleg enostavnih sistemov komuniciranja poznamo tudi bolj kompleksne sisteme z enim ali več komunikacijskimi kanali. Sestavljajo jih lahko:

- en oddajnik in več sprejemnikov;

- več oddajnikov in en sprejemnik;

- več oddajnikov in več sprejemnikov.

Komuniciranje, pri katerem obstajata en oddajnik in en sprejemnik, kateremu je poslano sporočilo namenjeno, imenujemo usmerjeno komuniciranje. V takih sistemih se lahko zgodi, da obstaja še eden ali več sprejemnikov, ki je poslano sporočilo sposoben sprejeti in razumeti njegov pomen, sporočilo pa mu ni namenjeno. Če imamo enega ali več sprejemnikov, je mogoč tudi selektiven pristop sprejemnika do oddajnika. Selektiven pristop pomeni, da mora sprejemnik poznati tudi zaščitno kodo, ki mu omogoča sprejeti poslano sporočilo. Zaščitna koda je del poslanega sporočila oddajnika, ki določenemu sprejemniku omogoči, da proces komuniciranja z dotičnim oddajnikom lahko poteka. Hkrati pa onemogoči sprejem poslanega sporočila sprejemniku, ki zaščitne kode ne pozna. To uporabljamo pri nekaterih sistemih komuniciranja, kjer imamo en oddajnik, en 
komunikacijski kanal in več sprejemnikov, vsebina poslanega sporočila pa sme biti dostopna le sprejemniku, kateremu je namenjena.

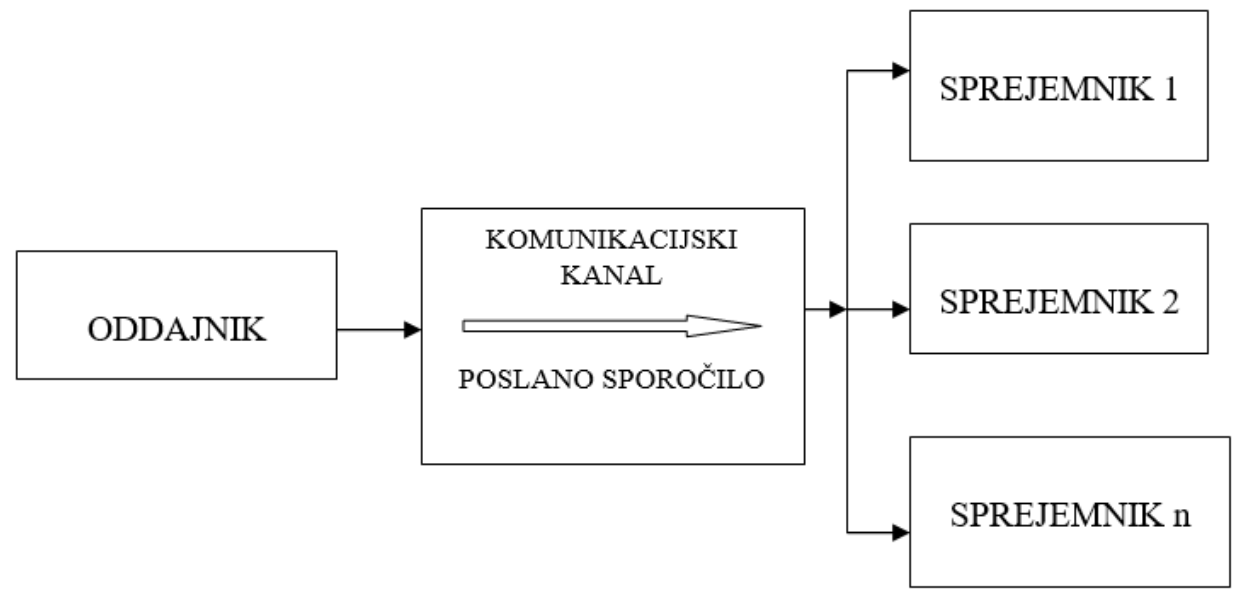

Slika 2: Sistem komuniciranja z enim oddajnikom in več sprejemniki.

Slika 2 prikazuje sistem enega oddajnika in več sprejemnikov, vezanih na isti komunikacijski kanal.

Poznamo tudi take sisteme komuniciranja, kjer je zaželeno, da bi poslano sporočilo enega oddajnika zaznalo čim več sprejemnikov. Če je sporočilo namenjeno več sprejemnikom, katerih oddajnik ne pozna, to imenujemo neusmerjeno komuniciranje.

Glede na naravo sprejemnika, oddajnika in komunikacijskega kanala ločimo:

- neposredno komuniciranje med ljudmi;

- komuniciranje s pomočjo tehničnih sredstev, kjer je začetni oddajnik in končni sprejemnik človek;

- medsebojno komuniciranje tehničnih sredstev;

- druge oblike komuniciranja.

Vidikov proučevanja komuniciranja je več:

- vidik vsebine komuniciranja;

- vidik odnosa oddajnika do sprejemnika in do vsebine;

- vidik odkrivanja lastne osebnosti oziroma lastne identitete;

- vidik vplivanja na sprejemnik.

V nadaljevanju se bomo pretežno ukvarjali s komuniciranjem med ljudmi. Pri tem se ne bomo omejili zgolj na interpersonalno komuniciranje. Oglejmo si najprej značilnosti oddajnika, sprejemnika, simbolov in prenosnih kanalov pri komuniciranju ljudi. 


\section{ODDAJNIK}

Človek komunicira tako na zavedni, kot na nezavedni ravni. V vsakem primeru pri nastajanju sporočila morajo sodelovati možgani. Kadar človek komunicira na zavedni ravni, na strani oddajnika potekajo procesi: razmišljanje, kodiranje in neposredna oddaja sporočila. Zaporedje procesov na strani oddajnika prikazuje slika 3.

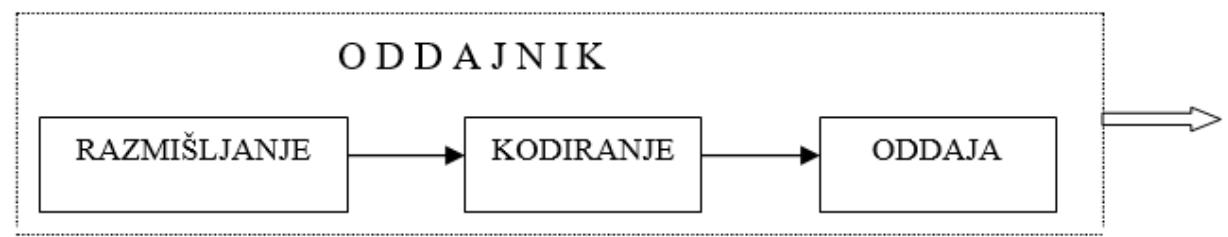

Slika 3: Zaporedje procesov na strani oddajnika

Vsebino zavednega komuniciranja človek običajno najprej zasnuje na miselni ravni. Med procesom komuniciranja človek kot oddajnik sporočila razmišlja:

- o tem, kaj s sporočilom želi doseči (se pravi o ciljih komuniciranja);

- o vsebini komuniciranja;

- o časovni dimenziji in dinamiki pošiljanja simbolov;

- o simbolih, katere namerava poslati in o njihovem pomenu (o semantiki, to je pomenu besed);

- o tem, ali naj bo sporočilo »minljivo« ali »neminljivo«;

- ali je kanal sploh sposoben prenesti sporočilo v želeni obliki do sprejemnika;

- ali je kanal komuniciranja za oddajnik in za sprejemnik »zaupanja vreden«;

- ali bo poslane simbole sprejemnik pravilno razumel;

- o lastnem ravnanju in čustvovanju med procesom komuniciranja;

- o tem, ali bo poleg potrebnih simbolov podzavestno poslal še kakšne druge;

- o morebitnih motnjah v komunikacijskem kanalu;

- o drugem.

Da pa bi bilo vsebino sporočila sploh možno prenesti do sprejemnika in da bi sporočilo oddajnik in sprejemnik razumela na enak način, mora biti že zaradi fizioloških principov komuniciranja vsebina izražena $\mathrm{v}$ simbolih. Pretvorba vsebine v simbole se imenuje kodiranje. Koda je način sporazumevanja s simboli, znaki in pravili oziroma protokoli. Simboli morajo biti take narave, da se lahko prenašajo po komunikacijskem kanalu. Oddajnik jih mora biti sposoben oddati, sprejemnik pa jih mora biti sposoben sprejeti. Ljudje se običajno sporazumevamo verbalno, to je z besedami, oziroma z jezikom. Jezik je množica besed. Ljudje, ki govorijo isti jezik, istim besedam običajno pripisujemo enak pomen. Poleg besednega oziroma verbalnega sporočanja med procesom komuniciranja ljudje zavestno ali podzavestno oddajamo tudi druge simbole. Tudi ti imajo nek pomen, 
Teoretične osnove komuniciranja: Oddajnik

vendar nebesednim simbolom sprejemnik in oddajnik neredko pripisujeta različen pomen. Ti simboli bodo obdelani v enem od naslednjih poglavij.

Fazi kodiranja sledi oddaja sporočila v komunikacijski kanal. V procesu komuniciranja sodeluje človekovo telo kot celota. Simbole oddajamo hkrati na zavedni in na nezavedni ravni. Kadar ljudje komuniciramo s pisano ali govorjeno besedo, zavestna oddaja pomeni zavestno izgovorjavo ali zapis besede. Oddajo simbolov na nezavedni ravni se ne zavedamo. 


\section{KOMUNIKACIJSKI KANALI}

Vrsta uporabljenega komunikacijskega kanala je odvisna od načina komuniciranja. Najbolj pogosta oblika komuniciranja med ljudmi je pogovor. Govorjena beseda zvok. Ta se po zakonih fizike prenaša po snoveh do sprejemnika. Pri interpersonalnem komuniciranju človeštvo $\mathrm{v}$ zadnjih desetletjih uporablja avdioakustična in telekomunikacijska sredstva. Uporabljamo ozvočenja, telefone, pošljemo elektronsko pošto ali sms. Med procesom komuniciranja tako poznamo:

- komunikacijske kanale, ki takoj prenesejo poslano sporočilo k sprejemniku, oziroma čas prenosa poslanega sporočila lahko zanemarimo;

- komunikacijske kanale, pri katerih prenos poslanega sporočila od oddajnika $\mathrm{k}$ sprejemniku traja nekaj časa.

Nadalje poznamo komunikacijske kanale, ki sprejemniku omogočijo večkratno sprejemanje istega sporočila. Poslano sporočilo se med procesom komuniciranja na tak ali drugačen način nekje shrani. Poznamo pa tudi takšne kanale, pri katerih je mogoč samo enkraten sprejem. V tem primeru se poslano sporočilo med procesom komuniciranja ne shrani, torej je minljivo.

Kot vidimo, komunikacijski kanali niso vedno tako preprosti, kot se zdi. Karikirano povedano, komunikacijski kanal je lahko zrak, lahko pa zelo zapleteno in drago tehnično sredstvo.

Kot navajata Cantoni in Danowski (2015), se sredstva komunikacijske tehnologije uporabljajo šele zadnjih 200 let, kar predstavlja komaj 0,1\% časa v človeški zgodovini.

Cantoni in Danowski (2015) prelomne dogodke v zgodovini kanalov komuniciranja povzemata takole:

- 8.000 let pred našim štetjem so nastale prve stalne naselbine. Ljudje v različnih naselbinah so se med seboj obveščali z dimnimi signali in bobni.

- 3.100 let pred našim štetjem je nastal prvi znan sistem pisave v Mezopotamiji in Egiptu.

- 500 let pred našim štetjem se je pojavila prva abeceda.

- 443 let pred našim štetjem je nastal Herodotusov zapis o vojni med Grki in Perzijci, ki je prvi znan zapis v zahodni civilizaciji.

- 59 let pred našim štetjem je Julius Caesar v Rimu odredil, da se o delu senata morajo pisati obvestila na forumu.

- 45 let pred našim štetjem je bil $\mathrm{v}$ starem Rimu odprt forum $\mathrm{z}$ dnevnimi novicami.

- Leta 1041 je Bi Sheng na Kitajskem izumil sistem tiskanja kitajskih črk.

- Leta 1450 je Johann Gutenberg izumil tisk.

- Leta 1609 je v Nemčiji začel izhajati prvi tiskan časopis. 
- Leta 1789 so v ZDA uzakonili svobodo govora in tiska (Bill of Rights).

- Leta 1833 so v ZDA časopis The New York Sun začeli prodajati za 1 peni, s tem so časopisi postali masovno dostopni.

Zgodovinski razvoj kanalov komuniciranja ni pomenil zgolj razvoja tehničnih sredstev za prenos simbolov, pač pa je imel tudi druge pomembne posledice. Vplival je na razvoj gospodarstva in odnosov v družbi nasploh. Povečala se je pogostost komuniciranja med ljudmi. Čas enega komunikacijskega stika se je skrajševal. Izumi so povzročili, da so se začela pojavljati tudi druga vprašanja:

- Kaj in kdo z izumom pridobi?

- Kaj se z izumom izgubi oziroma kaj postane zastarelo? Kdo in kaj z izumom izgubi?

- V kakšnem smislu izum pomeni spodbudo za nadaljnji razvoj?

Posledice so se nanašale na razvoj družbenih, političnih in ekonomskih odnosov ter na razvoj človeštva kot celote. Vprašanja so postala še posebej aktualna sredi 19. stoletja, ko je razvoj tiskarstva omogočil masovno uporabo tiska. Časopisi so začeli izhajati dnevno. $\mathrm{V}$ povezavi s časopisi se je v ospredje postavila državljanska razprava o širših javnih zadevah in začela se je izpodbijati avtoriteta oblasti. Cantoni in Danowski (2015) pravita, da so bili sredi 19. stoletja ameriški časopisi zgolj servis političnih strank. Tiskani mediji pa vendarle niso bili zgolj kanal za razširjanje informacij o politiki, pač pa so postopoma postajali tudi kanal za razširjanje informacij o podjetjih in o produktih. Prav razvoj tiskanih medijev je bil eden od pogojev za kasnejši pojav koncepta marketinga. Prvi plačani oglas v časopisu je bil objavljen že leta 1704. S tem se je spremenil poslovni model podjetij. Toda sprememba poslovnega modela podjetij, ki je bila posledica razvoja medijev, je imela povratni vpliv tudi na razvoj medijev. Lastniki časopisov, ki so se sredi 19. stoletja prodajali za 1 peni, so objavljali oglase za ceno 1 dolar. Oglaševanja je bilo sčasoma vedno več in več. Tiskani mediji so se posledično začeli komercializirati. Interes je bil povečati število bralcev in s tem število oglasov. Mnogi založniki so se trudili, da bi našli načine za hitro povečevanje naklade. Novice v tiskanih medijih so postale tržno blago.

Vzporedno z razvojem tiskanih medijev so se razvijale tudi telekomunikacije. Telekomunikacije so prenos vsebin na daljavo z uporabo tehničnih sredstev. Balbi in John (2015) opredeljujeta štiri obdobja razvoja telekomunikacij:

- obdobje optičnega telegrafa;

- obdobje električnega telegrafa;

- obdobje žične telefonije;

- obdobje brezžične telefonije.

Optični telegraf je omogočal prenos optičnih simbolov na razdalji do $30 \mathrm{~km}$. Prvi ga je demonstriral Claude Chappev leta 1792 v Franciji. Kot simboli so se uporabljala svetlobna oziroma optična znamenja. Oddajniki in sprejemniki so bili locirani na stolpih. Za sprejemanje so se uporabljali teleskopi. 
Leta 1844 je Samuel Morse izumil električni žični telegraf. S tem se je začelo povsem novo obdobje telekomunikacij. Simboli Morse-jeve abecede so bili sestavljeni iz kombinacij električnih signalov dveh različnih časov trajanja (iz »pik« in »črt«) ter »presledkov« med njimi. Električni žični telegraf se je najprej začel komercialno uporabljati kot pripomoček pri železniškem prometu, nato pa tudi širše. Do začetka II. svetovne vojne je bil glavni pripomoček za distribucijo şporočil na daljavo.

Obdobje žične telefonije se je začelo po letu 1870, komercialna uporaba pa po letu 1900. Žični telefon je bil prvo tehnično sredstvo, ki je omogočilo interpersonalno komuniciranje na daljavo.

Obstoj elektromagnetnega valovanja je med leti 1880 in 1890 odkril Heinrich Rudolf Hertz. Za izumitelja uporabnega komuniciranja s pomočjo eletromagnetnega valovanja (radijskih valov) pa velja Guglielmo Marconi, ki je leta 1909 za svoja odkritja prejel tudi Nobelovo nagrado. Pomembno delo na tem področju je v istem časovnem obdobju opravil tudi Nikola Tesla. Radio Ljubljana je začel oddajati leta 1928.

Prvi delujoč mobilni telefon je bil predstavljen leta 1977. SIM kartica je bila predstavljena leta 1990.

Balbi in John (2015) pravita, da je razvoj telekomunikacij potrebno preučevati iz treh vidikov:

- iz tehničnega vidika;

- iz vidika vplivov na ekonomijo;

- iz vidika vplivov na socialne in politične odnose ter na kulturo družbe.

Iz vidika komuniciranja organizacij z okoljem v 20. stoletju je treba vsaj omeniti komercialno uporabo filma in nosilcev zvoka. Začetek množične uporabe filma in nosilcev zvoka časovno sovpada z pojavom koncepta marketinga, zato so ti nosilci takoj postali tudi kanal za promocijo.

Konec 20. stoletja je zaznamoval internet. Začetki interneta so sicer začeli nastajati že v šestdesetih letih in konec sedemdesetih let prejšnjega stoletja. Eno od najpomembnejših odkritij za razvoj interneta je odkritje hiperbesedila (Hyper-Text) hipermedijev (HyperMedia).

Hiperbesedilo je sestavljeno iz dveh enot: iz blokov besedil (tekstov) in elektronskih povezav (linkov) med njimi. Kot navajata Tardini in Cantoni (2015) je besedo »HyperText« prvič omenil Theodor Holm Nelson leta 1965, korenine koncepta pa segajo še v leto 1945 , ko so se že začeli uporabljati mehanski iskalniki dokumentov oziroma besedil. Prvi računalniški prototip iskalnika je leta 1968 izdelal Douglas Engelbar. Najpomembnejše pa je odkritje aplikacije HTML (HyperText Markup Language), ki je skupaj s protokolom HTTP (HyperText Transfer Protocol) postala ena od osnov današnjega svetovnega spleta. 
Hiperbesedila lahko v grobem razdelimo na statična in dinamična. Pri statičnih je videz vsakega posameznega bloka besedila $v$ celoti vnaprej določen s strani avtorja oziroma oblikovalca, pri dinamičnih pa so določena samo pravila za njihovo ureditev.

Internet je mreža računalnikov in povezav med njimi. Prva delujoča mreža računalnikov in povezav med njimi je bila vzpostavljena leta 1969. Izmenjava podatkov med računalniki poteka po protokolih. Protokol TCP (Transmission Control Protocol), ki je bil osnova sodobnemu internetu, se je začel uporabljati leta 1983.

V zadnjih 20 letih so se s pojavom interneta pojavili tudi novi kanali komuniciranja med ljudmi. Gre za pojav družbenih oziroma socialnih omrežij. Za razvoj današnjih družbenih omrežij je potrebno vsaj omeniti razvoj iger na srečo in video-igric. Video igrice so bile predhodnice spletnih igric. Prav okoli spletnih igric pa so nastale prve internetne skupinepredhodnice današnjih socialnih omrežij.

Siitonen (2015) pravi, da so igre na srečo in igre na splošno družbena dejavnost. Za tiste, ki so motivirani za sodelovanje, igre na srečo, video igre, digitalne igre in spletne igre ponujajo neskončno načinov za izražanje samega sebe in za druženje.

Young (2015) lastnosti socialnih omrežij povzema v naslednjem:

Participacija: Socialna omrežja spodbujajo prispevke in povratne informacije od vsakogar, ki ga neka vsebina zanima. To briše mejo med konceptom medijev in občinstva.

Odprtost: Socialna omrežja so odprta za povratne informacije in sodelovanje.

Konverzacija - medtem ko tradicionalni mediji »oddajajo", vsebine, so socialni mediji mnogo bolj dvosmerni.

Skupnost: Socialna omrežja omogočajo hitro oblikovanje »skupnosti« na podlagi skupnih interesov.

Integriranost: Prek povezav socialna omrežja združujejo različne vrste medijev na enem mestu.

Aakhus-a in DiDomenico (2016) je preučevanje še družbenih omrežij še posebej zanimalo zato, ker družbena omrežja omogočajo interakcije med okolji, s katerimi brez novih medijev to nikakor ne bi bilo mogoče. Družbena omrežja omogočajo svobodo izbire iskanja vira in svobodo objave informacije. Svoboda po drugi strani seveda omogoča tudi manipulacije in posredovanje lažnih novic. Vendar si uporabnik na podlagi različnih virov lahko ustvari svoj kritičen odnos tako do kanala kot do vsebine. 
Po letu 2004 se je začel uporabljati internet 2.0. (Web 2.0). Tardini in Cantoni (2015) navajata tri bistvene lastnosti interneta 2.0:

- velika širitev možnosti, da uporabniki na spletu objavijo svoje vsebine;

- možnost, da si ljudje vsebine delijo oziroma si jih izmenjujejo;

- možnost objave in izmenjave multimedijskih vsebin.

Internet 2.0 je še vedno osredotočen na dokumente in na iskanje dokumentov. Bodoči internet 3.0 (Web 3.0) ali semantični splet se bo najverjetneje osredotočil na izdelavo dokumentacije za naprave, ki omogočajo avtomatsko obdelavo in na informacijsko podporo avtomatskim napravam. 
Teoretični osnove komuniciranja 


\section{POMEN SIMBOLOV}

\section{Govorjena beseda}

Skozi evolucijo človeka se je govor pojavil dokaj zgodaj. Vendar pa pogovor ni bil prva oblika interakcij med ljudmi. Z govorom človek izraža vsebino, izrazi svoja čustva in odraža svojo identiteto. Bržkone govor ostaja temeljna oblika komuniciranja. Pravi pomen besednega simbola dobimo šele s stavkom. Govora ne moremo obravnavati ločeno od drugih simbolov. Vsak človek ima svoj značilni glas. Človeka lahko identificiramo z glasnostjo govora in z barvo glasu. Če bi človekov govor neposredno pretvorili v električno napetost, bi se ta spreminjala v frekvenčnem območju od $16 \mathrm{~Hz}$ do $20 \mathrm{kHz}$. Vsak človek ima drugačen frekvenčni spekter svojega glasu. Barva glasu je človeku prirojena. Glasnost in barvo glasu človek zavestno ali podzavestno tudi spreminja. Energičen ali jezen človek bo npr.: govoril glasno, ravnodušen monotono. $Z$ višjim tonom ljudje poudarjamo. Če v delu govora želimo posebno pozornost poslušalstva, z glasom naredimo sekundo ali dve trajajoč premor. Iz karakteristik človekovega govora lahko razberemo skoraj vsa čustvena stanja. Razberemo lahko tudi številne napake in tudi odlike govora.

Jezik je sistem medsebojno povezanih zvočnih simbolov, značilen za skupino. Je družbeni pojav, ki ima formalna pravila in pomen. Najbolj so jeziki razviti z glasovnimi znaki. Vsak jezik pa ima tudi elemente, ki jih ni mogoče reducirati na glasovne oblike (npr. ritmika, poudarjanje, mimika).

Jezik je sestavljen iz dveh komponent:

- vsebinske, ki jo proučuje semantika,

- formalne, ki jo proučuje gramatika.

Vsak jezik ima besednjak ali zbirko besed. Jeziki se po po pomenu zvočnih simbolov precej razlikujejo. Besednjak je odvisen od človekovega načina življenja in dela (npr. samo v znanstveno in kulturno razviti deželi se razvije bogata terminologija.). Posamezniki uporabljajo le del besednjaka svojega jezika.

Govor je že tisočletja predmet številnih proučevanj. Veda, ki proučuje govorništvo, je retorika. Retorika (Knaus, 2014) je praktični niz navodil za učinkovito besedno komuniciranje. Starodavno retoriko je moč proučevati od obdobja, ko se je pojavila pisava. Ker so stari Grki že poznali pisavo, je dokazano, da je retorika kot veda stara vsaj 2500 let.

Prvi opis govorniškega nastopanja sega v Homerjevo Iliado. Homer je opisal dialog med Menelaosom in Odisejem. Opisuje govornikovo zunanjost, glas, obnašanje in ideje... Kot je razvidno iz Homerjevih zapisov, so njegovi junaki že razvili potrebno znanje za 
govorništvo. Zavedali so se, da sta retorično znanje in spretnost nepogrešljivi za uspeh v katerikoli družbi.

Za očeta govorništva velja filozof Empedokles iz Akraganta na Siciliji (živel približno od leta 495 do 435 pred našim štetjem). Bil je prvi, ki je ustanovil šolo govorništva.

Še vedno je aktualna Aristotelova definicija retorike, ki pravi: "Retorika je veščina odkrivanja in uporabljanja vseh dosegljivih sredstev prepričevanja pri katerikoli zadevi." Retorika je že od Aristotela uvrščena v praktično filozofijo. Aristotel (živel približno od leta 384 do leta 322 pred našim štetjem) je predvideval, da se ljudje med seboj zgolj obtožujejo in branijo. Po Aristotelu so najpomembnejši dejavniki, ki vplivajo na uspešnost prepričevanja: etos, logos in patos (ugled govornika, logično dokazovanje in izkoriščanje čustev).

Etos ali ugled govornika si lahko predstavljamo kot vnaprejšnje prepričanje poslušalcev o njegovi poštenosti, etičnosti in dobronamernosti. Nekaterim govornikom ljudje že vnaprej verjamejo vse, kar povedo, ker uživajo velik ugled.

Logos ali razumsko dokazovanje pomeni vplivanje na razumsko sklepanje poslušalcev. Dokazovanju pravimo tudi argumentacija. To je najtežje področje retorične veščine. Za uspešno logično dokazovanje ima govornik samo dve možnosti: prehod od splošnega $h$ konkretnemu ali prehod od konkretnega $\mathrm{k}$ splošnemu.

Patos pomeni ustvarjanje čustvenega vznemirjenja med poslušalci. To je mogoče na več načinov:

- govoriti tisto, kar poslušalci želijo slišati;

- z elokvenco.

Elokvenca pomeni govorniški stil. Stilistična sredstva so: ritem, rime, prispodobe, primerjave ipd.

Med govornikom in poslušalci, je Aristotel identificiral: čustva zadovoljstva, nezadovoljstva, ljubezni in sovraštva.

Po Aristotelu obstajajo tri vrste govora: politični, sodni in epideiktični.

$\mathrm{V}$ politiki ima govor poseben pomen; politika opozarja, od česa odvrača in spodbuja $\mathrm{k}$ splošnemu dobremu (pri čemer politik sam definira, kaj je dobro). Politični govornik predvideva prihodnost za razliko od sodnika, ki ima ob svojem govorništvu v mislih preteklost.

Sodnik govori o pravici in krivici.

Epideiktični govorec po mnenju Aristotela hvali ali graja; govori pa o sedanjosti. 
Po propadu grških polisov se je znanost preselila v stari Rim. Eden najpomembnejših retorikov starega Rima je bil Marcus Julius Cicero (živel od leta 106 do leta 43 pred našim štetjem). Bil je teoretik in tudi praktik, saj je bil znamenit govorec in politik. Ohranili so se tudi njegovi zapisi. Septembra 1416 so v kleti neke opatije menihi Poggio Bracciolini, Cincio Romano in Bartolomeo Montepulciano odkril rokopis celotnega besedila dela Quintilian's Institutio oratoria. Približno stoletje kasneje je škof Gerardo Landriani našel celotno besedilo Cicerovega dela De oratore. Ti dve deli bržkone v Evropi ostajata temeljni vir znanja o retoriki.

Knaus (2014) povzema, da se je retorika po svoji poti ločeno razvijala tudi v nekaterih drugih delih sveta; ločeno od evropske civilizacije na Kitajskem in pred letom 1492 tudi v Ameriki.

Ne glede na to, da je retorika stara že tisočletja, se praktično ista pravila uporabljajo še danes. Pravila retorike je potrebno upoštevati pri vseh oblikah komuniciranja, od pogovora, pa vse do oblikovanja vsebin spletnih strani.

Kot navaja Esposito (2007) so predmet sodobnega preučevanja interpersonalnega komuniciranja predvsem: mimika, razlike med formalnimi in neformalnimi načini komuniciranja; kulturne razlike in posamezne in družbeno-kulturne razlike; stabilne osebnostne lastnosti in njihova stopnja izraznosti kot tudi individualizacije čustvenih in psiholoških stanj sogovornikov.

\section{Sodobna retorika je tako znanost kot veščina.}

Poznamo več stilov govorništva, kot npr.:

- zapleteni stil (uporaba tujk in odmaknjenost od vsakdana);

- začetniški stil (nesproščenost, napetost, nezaupanje vase);

- širokoustni stil (pretirano samozaupanje, poudarjanje svojih sposobnosti);

- stil dejstev (prepričevalnost in praktični primeri);

- enolični stil (enoličnost po vsebini in temperamentu govora);

- čustveni stil (izbrano izrazoslovje, povezano s primerno gestikulacijo).

Za učinkovit govor moramo združiti vsebino in obliko povedanega. Svoj govor izboljšamo z zavestno uporabo neverbalnih oblik sporočanja (npr.: govorico telesa, pogledi, mimiko, gibi, držo) in z glasovnimi elementi (višino, jakostjo, barvo, tempom, razločno izgovorjavo). Poslušalce pritegnemo tudi s čustvi (govorimo navdušeno, prepričljivo, zavzeto, uporabljamo retorične presledke, idr.).

Pri zbiranju podatkov, ki bodo pomagali pri oblikovanju govora je pomembno, da se vprašamo:

- Kdo so poslušalci (množica ljudi, mladina, strokovnjaki)?

- Kaj želimo doseči (prepričati, obveščati, zabavati, podati v presojo...)?

- V kakšni vlogi bomo nastopili (kot učitelj, vodja, prodajlec, kupec, ipd.)?

- Kakšno je dejansko stanje stvari, o kateri bomo govorili? 
- Kaj je bistveni problem (ocenimo ga $\mathrm{z}$ več vidikov)?

- Katere podatke potrebujemo za razčlembo in oblikovanje lastnih argumentov?

- Koliko časa bomo imeli na razpolago?

- Kako bomo izpeljali nastop (si pripravili oporne točke, govorili na pamet, kako bomo uporabljal gibe, poglede, poudarke, kje bom delal premore.)?

- Kakšne presentacijske pripomočke bomo uporabljali?

Enkelmann (1996) podaja naslednja navodila za izvedbo dobrega govora:

- Z občinstvom miselno vzpostavite stik!

- Povejte tisto, kar mislijo in čustijo poslušalci!

- Začnite z mislijo, o kateri lahko vsakdo reče "da"!

- Vaš interes naj bo jasen drugim!

- Odloča učinkovitost, ne količina besed!

- V središču govora navedite tri osrednje točke (začenši z najšibkejšo)!

- Zaključna poved naj bo formulacija, ki spodbuja $\mathrm{k} u k r e p u !$

- Vaditi je treba toliko časa, dokler ne dosežete mojstrstva!

Ob obravnavi retorike smo težišče obravnave namenili oddajniku. Toda za uspešno komuniciranje je pomembno tudi poslušanje sogovornika.

Obstajajo številni priročniki z navodili in vajami za pridobivanje govornih spretnosti. Priročniki so navadno napisani na podlagi osebnih izkušenj avtorjev. V nadaljevanju iz teh priročnikov povzemamo nekaj praktičnih nasvetov. ${ }^{4}$

Čas, ki je na voljo za govor, naj bi razporedili v uvod, jedro in zaključek. Ljudi je treba najprej navdušiti. Šele potem jih je mogoče tudi prepričati. V uvodu pojasnimo vzroke in povode za govor, motiviramo poslušalce, opredelimo problem in poiščemo aktualne interakcije. $Z$ uvodom želimo pritegniti poslušalce $\mathrm{k}$ poslušanju. Predstavimo se lahko sami, lahko pa nas predstavi nekdo drug. Posredujemo tiste podatke o sebi, za katere želimo, da so omenjeni in ki bi utegnili zanimati poslušalce. Pomembno je, da v uvodu spodbudimo pozitivne predstave pri poslušalcih. Ne začenjamo z dolgim pozdravljanjem ali opravičilom. Govor lahko začnemo na naslednje načine:

- $\quad \mathrm{z}$ vprašanjem;

- s pripovedjo kratke zgodbe, anekdote;

- z opisom skupnega problema;

- z opisom pomembnega dogodka.

V nobenem primeru ne poudarjajmo, kako na govor nismo pripravljeni.

\footnotetext{
${ }^{4}$ Viri so navedeni v literaturi. Pravega avtorja posameznega nasveta je zelo težko ugotoviti, ker se posamezni nasveti $v$ različnih virih pogosto ponavljajo, pogosto pa v priročnikih niso navedeni izvorni viri.
} 
V jedru opredelimo problemsko stanje, opišemo situacijo, želeno stanje, zastavljene cilje, načine za njihovo dosego in alternative. Osrednjo misel moramo podrobneje pojasniti in razložiti. Začnemo lahko s splošnim opisom in pri tem uporabljamo nazorne primere.

Vrhu govora naj bo argumentacija. Poslušalcem pojasnimo, kakšne povezave imajo argumenti z njihovimi željami, potrebami, problemi, razmišljanji. Nikoli ne govorimo o argumentih, za katere že vnaprej vemo, da jih poslušalci ne bodo sprejeli. Uporabimo podatke, ki pritegnejo pozornost.

Po razlagi problema lahko najprej navedemo tiste argumente, ki govorijo $\mathrm{v}$ prid dejanskemu stanju, šele nato argumente proti. Lahko pa začnemo z lastnim mnenjem, ki ga utemeljimo.

Prepričljivi bomo le, če bo jedru sledil dober zaključek govora. Zadnji vtis je tisti, po katerem ostane poslušalcem govor najbolj v spominu.

Vse, kar smo povedali, strnemo $\mathrm{v}$ kratek in jedrnat povzetek. Ta naj bo poziv $\mathrm{k}$ akciji, določenemu dejanju, želja, opomin, svarilo, predlog. V zaključku povemo, kaj lahko prispevamo, $\mathrm{k}$ dosegi želenega, pozivamo $\mathrm{k}$ dejanjem, poslušalce spodbudimo, da se še naprej zanimajo za to področje. Lahko tudi povzamemo bistvene poudarke govora.

Za poslušanje se praviloma ne zahvaljujemo.

Govorimo na pamet. To ne pomeni, da se govora moramo naučiti na pamet. Če se ga namreč naučimo na pamet, poslušalci to opazijo.

Poslušalci pripisujejo velik pomen tudi drugim, neverbalnim simbolom, katere pošilja govornik. Pomembno je, da poleg vsebine naredimo dober vtis. Poslušalcem se poskušamo iskreno nasmehniti. Nasmejan obraz je povsod po svetu znak sreče, jokajoč pa odsev bolečine in žalosti.

Ko govorimo, govorimo občinstvu, zato med govorom gledamo občinstvo. S pogledom se ne ustavljamo pri posameznem poslušalcu. Pogleda tudi ne obračamo preveč sunkovito.

Med govorom stojimo pokončno. Ramen ne povešamo. Dober govor mora biti primerno podkrepljen s kretnjami rok.

Govorni nastop lahko močno izboljšamo z obvladovanjem intonacije, barve glasu, jakosti ter tempom in premori. Premori ustvarjajo napetost. S pomočjo svojega glasu moramo doseči živahnost in napetost.

Seveda nas bo pred govorom mučila trema. Trema pred govorom se navzven kaže kot: zardevanje, tresenje rok, vročica, potne roke, "cmok v grlu", v hujših primerih pa celo kot prebavne motnje. Avtorji literature navajajo številne nasvete, kako premagati tremo. Pomagajo govorne vaje. Z izkušnjami se trema manjša. 
Omeniti velja, da smo si ljudje pri poslušanju in še zlasti pri odzivanju med seboj zelo različni. Schmitz (1993) sogovornike razvršča takole:

- klepetulje (bi radi govorili o vsem, le o vsebini ne);

- zgovorneži (vejo vse in tudi govorijo o vsem);

- impulzivni (zelo hitro reagirajo);

- nestrpneži (pogosto skačejo v besedo);

- zaposleni (navadno počnejo več stvari hkrati in nimajo veliko časa za pogovor);

- neodločni (vidijo vse, vendar svoje videnje lahko spreminjajo);

- mirni (so zadržani);

- koleriki (se pogosto "izdivjajo" nad sogovornikom);

- ciniki;

- drugi.

Za uspešen pogovor je pomembno, da prepoznamo tip sogovornika in mu pristopimo na primeren način.

\section{Pisno sporočanje}

Med izgovorjeno in zapisano besedo je nekaj pomembnih razlik:

- Napisano sporočilo je največkrat bolj brezosebno, medtem, ko je govorec $\mathrm{v}$ stalnem besednem in nebesednem stiku s poslušalci.

- Govorčev položaj je fleksibilen, saj lahko spremlja odzivanje poslušalcev in odzivom prilagaja svoj govor, zapisanega pa ni več mogoče prilagajati odzivu bralcev.

- Napisano sporočilo lahko ostane arhivirano, za izgovorjeno besedo pa to ni nujno.

Evolucijo razvoja pisnega sporočanja lahko razvrstimo v več obdobij:

- obdobje pred pojavom ročne pisave;

- obdobje ročne pisave;

- obdobje tiskanega sporočanja;

- obdobje elektronskega sporočanja.

V razvoju pisnega sporočanja so bili nekateri dogodki prelomni:

- 3.500 let pred našim štetjem so Sumerci znali zapisovati simbole na glinaste ploščice.

- 3.100 let pred našim štetjem je v Mezopotamiji in $\mathrm{v}$ Egiptu nastal prvi znan sistem pisave.

- 500 let pred našim štetjem se je pojavila prva abeceda.

- Leta 1451je Johannes Gutenberg odkril tisk in natisnil prvo knjigo v Evropi. 
- Leta 1565 je bilo izumljeno nalivno pero.

- Leta 1867 je bil izumljen pisalni stroj.

- Leta 1963 je bil razvit ASCII format (American Standard Code for Information Interchange), ki je postal osnova za razvoj elektronske pošte.

- Leta 1968 je bil predstavljen sistem tipkovnice in miške.

- Leta 1969 je bil izumljen princip laserskega tiskalnika.

- Leta 1982 je bil poslan prvi »sms.«

S pojavom elektronskega načina pisnega sporočanja, star način izmenjave pisnih sporočil na papirju seveda ni zamrl. Kljub temu, da danes ljudje mesečno pošiljajo tudi tisoč ali celo več sporočil v elektronski obliki, še vedno kakšno sporočilo zapišemo tudi na list papirja.

Prav tako kot govor, je tudi pisno sporočanje del identitete posameznika. Psihologija je skozi stoletja razvila grafologijo kot nauk o preučevanju ročne pisave. Izkušeni grafologi iz atributov ročne pisave znajo razbrati, kakšne so dimenzije osebnosti avtorja. Vendar identitete posameznika ne nakazuje zgolj ročno zapisano besedilo, pač pa tudi tiskano, še posebej pa elektronsko sporočanje. Iz izbire kanala, jezikovnih značilnosti, uporabe »smeškov«, okrajšav, simbolov, dinamike komuniciranja in drugih atributov je možno sklepati o značilnostih avtorja.

Tiskana besedila so $\mathrm{v}$ nekem obdobju razvoja postala zelo formalizirana. Formalni dokumenti (kot so npr.: vloge, dopisi, sklepi, ipd.) morajo vsebovati ključne formalne sestavine in so skoraj brezosebni.

V obdobju elektronskega sporočanja elektronskih sporočil postaja čedalje več, zato se po obsegu tudi krajšajo. Elektronska sporočila so vedno manj formalna. Za pisanje dolgih sporočil ljudje enostavno nimajo več časa. Naglica pogosto odpira prostor za spontanost, kar ima za posledico hoteno ali nehoteno izražanje lastne identitete. Obdobje elektronskega sporočanja je torej spet čas, ko prek različnih elementov človek hote ali nehote pokaže svojo individualnost. Zato je ta oblika sporočanja spet postala predmet preučevanja psihologov. Tudi posamezne dimenzije elektronskega sporočanja, podobno, kot atributi ročne pisave, lahko izhajajo iz človekove osebnosti.

Perin (2016) ugotavlja, da tudi napisano sporočilo, pa naj si bo to ročno napisano, tipkano na papir ali v elektronski obliki, povzroči interakcijo v obliki razmišljanja in čustev tako na strani tistega, ki je besedilo napisal, kot na strani bralca. Pisno sporočanje je zato že dolgo predmet preučevanja raziskovalcev. Skozi zgodovino se je najprej razvilo preučevanje človeških pisav. Nauk o človeški pisavi je grafologija. Grafologija (Poizner, 2012) je veda, ki skuša razumeti, interpretirati in sistematično graditi študijo znakov posameznika. Grafologija vključuje ocenjevanje vzorcev rokopisov v skladu z uveljavljenimi protokoli, da bi opisali lastnosti osebnosti pisatelja.

Za začetnika grafologije se šteje Francoz Jean Hippolyt Michon, ki je proučeval pisavo v drugi polovici 18. stoletja. Njegov pristop k proučevanju pisave je temeljil na hipotezi, 
da obstaja povezava med določenimi grafičnimi znaki in človeškim značajem. Tak pristop je danes zastarel.

Grafologi danes pravijo, da je pri razlagi pisave treba upoštevati naslednje:

- Pravilno je treba izbrati vzorec, na katerem bo opravljena grafološka analiza.

- Človek nikakor ne sme vedeti, da bo vzorec njegove ročne pisave grafološko analiziran, zato vzorec pisave ne sme biti napisan v namen grafološke analize.

- Pisalo mora biti primerno.

- Poiskati je treba dominantno lastnost pisave, ki je merilo vseh preostalih lastnosti.

- Na podlagi enega samega znaka ali premajhnega vzorca ni mogoče nikakršno sklepanje.

Slyter (1995) navaja, da je razvito, naravno pisanje skoraj avtomatsko dejanje. Ko pa človek pisanju posveti pozornost, njegova pisava postane drugačna.

Temeljno pravilo analize pisav pravi, da pisave lahko uspešno analizira zgolj strokovnjak $\mathrm{z}$ dovolj izkušnjami. Analiza na podlagi tabel in povzetkov (kot je prikazano $\mathrm{v}$ nadaljevanju zgolj kot ilustracija) je lahko napačna. Nadaljnji prikazi so torej zgolj informativni ${ }^{5}$ in ne služijo kot osnova za resno grafološko analizo pisave.

Grafologi, ki so se lotevali proučevanja pisave so izhajali iz celostne interpretacije pisave. Pisava je namreč večumna, celostna, saj je psihofizična kretnja. Izhodišči, iz katerih izhajajo proučevanja pisave sta (poenostavljeno povedano) navadno dve:

- sistematika pisalnih znakov;

- teorija izražanja.

Sistematiko pisalnih znakov grafologi navadno razvrščajo v tri skupine:

- gibalne poteze (velikost/majhnost, širina/ožina, vezanost/nevezanost potez ipd.);

- oblikovne poteze (oblike vezanja črk, polnost ali skopost potez, okrašenost oziroma zanemarjenost ipd.);

- prostorske poteze (kako pisec izrablja pisalno površino, kako potekajo vrste, poševnost oziroma pokončnost, razdalje med črkami in besedami ipd.).

Zgolj kot primer za razumevanje analize pisave predstavljamo nekaj primerov sistematike pisalnih znakov, na podlagi katere grafologi proučujejo naslednje:

Samoniklost pisave pomeni neodvisnost od pisalnih potez, naučenih v šoli. Pomeni izvirnost, samosvojost. Lepe pisave se navadno držijo pravil.

${ }^{5}$ Povzeto po virih: (Trstenjak, 1986), (Craze, 1994), (Slyter, 1995) in (Poizner, 2012). 
Ritem in takt pisave se kaže $v$ naraščanju in padanju vrst, v ponavljanju istih potez in znakov. Nekatere pisave so popolnoma neritmične. Ritem in takt kažeta na ritem in takt človekovega osebnega življenja.

Velikost ali majhnost pisave kaže na realističnost, premišljenost, skromnost, zadovoljstvo, čut za dolžnost, uklonljivost (majhna pisava) oziroma dostojanstvo, ponos (velika pisava). Če so črke večje od $3 \mathrm{~mm}$ gre za veliko pisavo, če so manjše od $2 \mathrm{~mm}$ gre za majhno pisavo.

Hitra in počasna pisava se odraža v gladkosti pisave. Pisava je gladka, če so črke kot iz ene poteze. Ljudje, ki veliko pišejo imajo hitro pisavo. Hitra pisava pomeni delavnost in podjetnost. Počasna pisava pa pomeni zbranost, previdnost in zanesljivost.

Trda ali rahla pisava označuje napor, ki ga ima človek pri pisanju. Gre za pritisk pisala na papir. Trde poteze naj bi bile debelejše, rahle tanjše. Rahla pisava pomeni sproščenost, rahločutnost. Trdo pisavo prepoznamo po zadebelitvah ob potezah navzdol. Trda pisava pomeni krčevitost volje.

Široka ali ozka pisava se prepozna po razmerju med višino in širino črk. Če je širina črk manjša od dolžine, gre za široko pisavo. Če je pisava široka, gre za naravnanost k cilju, osebno prizadevnost. Ozka pisava pomeni zadržanost, zmernost.

Zalita ali suha pisava: pri zaliti pisavi se loki in pentlje zlivajo v ploskve, zapolnjene s črnilom, suha pisava pa ima tanke črke. Zalitost je odvisna od drže pisala. Pomeni čustvenost. Suha pisava pomeni samodisciplino, tankočutnost in hkrati ostrost.

Pokončnost pisave pomeni prevladovanje razuma nad emocijami, nagnjenost v levo pa deluje nenaravno.

Zvezna pisava pomeni, da so črke med seboj povezane: Pri presledni pisavi pa lahko med črkami opazimo presledke. Za ljudi s presledno pisavo so značilne intuicija, ustvarjalnost in iznajdljivost. Če jo ocenjujemo negativno pomeni pomanjkanje logike. Zvezna pisava pa je značilna za ljudi z izrazitim logičnim razmišljanjem.

Polna ali prazna pisava pomeni zapolnjenost prostora na papirju. Pri nekaterih pisavah imamo vtis, da je prostor prazen, čeprav je list papirja v resnici popisan. Pri polni pisavi prevladuje domišljija, pri prazni pomanjkanje domišljije. Obogatenost pisave pomeni smisel za zunanjost. Poenostavljenje pisave pomeni prisotnost čuta za bistvo.

Visoka ali nizka pisava: Gre za to ali prevladujejo zgornje ali spodnje poteze pri oblikovanju črk. Tipična moška lastnost je v prevladovanju visokih potez, tipična ženska v prevladovanju nizkih.

Prostor in vrste $\mathbf{v}$ pisavi: Ravne vrste pomenijo premočrten, ravnodušen značaj, dvigajoče se vrste kažejo na optimizem, prizadevnost pri delu, padajoče vrste pa pomenijo potrtost. 
Teorija izražanja pa zagovarja tezo, da na podlagi pisave grafolog lahko odkrije človekov temperament in značaj. Ne more pa zanesljivo odkrivati nadarjenosti, inteligence, spola in starosti. Ločiti je sicer mogoče tipično moško od tipične ženske pisave. Teorija izražanja izhaja iz predpostavke, da se izrazno gibanje pri pisanju ravna po načelu izražanja in po načelu oblikovanja.

Načelo izražanja pravi, da energija izraznih gibov izvira iz gonskih pobud (čustev).

Načelo oblikovanja pravi, da pri vsakem namernem človekovem gibanju soodloča njegova podzavestna podoba o dejanju. Oblike, ki spominjajo na ne-črkovne podobe po tem pojmovanju izražajo predstave pisca.

Obdobje tiskanega sporočanja in kasneje obdobje elektronskega sporočanja je prineslo nove vidike obravnave. Perin (2016) navaja tri ključne vsebine preučevanja tiskanega sporočanja:

- vidik postopka izdelave tiskanega sporočila;

- vidik tiskanega sporočila samega;

- vidik socialnih interakcij, ki jih tiskana sporočila sprožijo.

Ob obravnavi tiskanega sporočila ne smemo zanemariti strojne pisave. Danes kot pisalni stroj najpogosteje uporabljamo osebni računalnik in ustrezna programska orodja. Preden se lotimo pisanja, ne smemo zanemariti nekaterih razmislekov.

Najprej moramo razmisliti, kateri tip pisave (font) bomo uporabili. Poznamo več vrst fontov; temeljna razlika med njimi je, da imajo nekateri zavihke ("serife"), drugi pa ne.

Namen zavihkov je, da pri branju na papir natisnjenega teksta omogočajo lažje sledenje vrstici. Zavihki imajo tudi estetsko vrednost, saj dajejo vtis, da so črke "mehkejše", bolj zaobljene. Zavihki dajejo vtis polnosti. Toda ko izdelujemo predstavitve se pogosto izkaže, da na platno projicirani fonti z zavihki z večje razdalje postanejo težje berljivi.

Praviloma za isti dopis uporabimo le eno vrsto fonta. Pomembno je, da izberemo ustrezno velikost črk. Pri oblikovanju klasičnega dopisa na papir formata A4 navadno izberemo pokončne fonte velikosti $12 \mathrm{pt}$. Za predstavitve na prosojnicah ali kakem programskem orodju uporabimo večje fonte (do $24 \mathrm{pt}$ ).

Razmislimo, kdaj uporabiti ležečo pisavo. Poudarjamo le naslove. Za dopise uporabljamo črno barvo črk. Če napišemo in oddamo tekst, ki je v celoti napisan s poudarjenimi črkami, lahko kdo dobi vtis, da kričimo.

Pomembne so tudi poravnave besedila in razmik med vrsticami. Sredinsko poravnavo uporabimo za naslove. Tekst poravnamo obojestransko. Razmika med vrsticami ne uporabljamo za to, da bi dajali vtis večje obsežnosti našega teksta. Preden dopis oddamo, si moramo ogledati predogled tiskanja. 
O sestavljanju vsebine različnih dopisov obstajajo različni priročniki. Ne bo odveč nekaj napotkov za sestavljanje vsebine dopisov. Elementi klasičnega dopisa so:

- ime, naslov, telefonska številka in elektronski naslov pošiljatelja;

- datum;

- ime in naslov prejemnika;

- zadeva;

- besedilo (ki sestoji iz: nagovora, uvoda, opisa problema in zaključka);

- pozdrav;

- podpis;

- post scriptum;

- poslano.

Poslovni dopisi pravnih oseb vsebujejo tudi podatke iz registra pravnih oseb, kot so:

- matično številko;

- identifikacijsko številko za davek na dodano vrednost;

- številko tekočega računa;

- SWIFT;

- IBAN;

- številko vpisa v sodni register.

O tem, kako napisati dobro poslovno pismo obstajajo številna navodila. Do receptov so avtorji $^{6}$ navadno prišli na podlagi izkušenj. Najpogostejši nasveti so:

- Pri roki imejte zbirko dobrih zgledov.

- Dobri pisci mislijo, medtem ko pišejo. Ne odlagajte pisanje na čas, ko boste imeli pri roki vse podatke.

- Preden vstanete od pisanja, grobo verzijo napišite do konca.

- Prizadevajte si, da bo vaše pisanje čim manj komplicirano.

- Ne pišite dolgih uvodov. Takoj preidite na konkretno zadevo. Ljudje imajo namreč tudi drugo delo, kot brati dolge uvode.

- Obravnavano tematiko obdelajte čim bolj sistematično.

- Predstavljajte si, da je vaš dopis telegram in da morate vsako zapsisano besedo plačati.

Zadnji nasvet še posebej velja za pošiljanje elektronske pošte in sporočil SMS prek omrežja GSM.

Za pisanje dopisov je priporočljivo upoštevati še naslednje:

- Nikoli ne pišite dopisa takrat, ko ste razburjeni.

\footnotetext{
${ }^{6}$ Pravega avtorja posameznega nasveta je zelo težko ugotoviti, ker se posamezni nasveti v različnih virih pogosto ponavljajo, pogosto pa v priročnikih niso navedeni izvorni viri.
} 
- Nikoli ne pošiljajte dopisov po elektronski pošti v petek popoldne ali v nedeljo zvečer!

- Pomembnega dopisa ne pošljite takoj, ko ste ga napisali. Počakajte naslednji dan in ga še enkrat preberite!

- Dopis mora biti čim krajši. Utemeljitve naj bodo v prilogah.

- Ozirajte se na bralca, njegove poglede in izkušnje.

- Pišite z namenom da razložite, ne da impresionirate.

- Pišite naravno, stil naj bo gladko tekoč in naj ne pritegne pozornosti.

- Pišite kratke stavke.

- Izogibajte se sestavljenim stavkom.

- Uporabljajte znane besede.

- Izogibajte se žargonskemu izražanju.

- Izogibajte se nepotrebnim besedam.

- Uporabljajte izraze, ki si jih bralec lahko predstavlja.

- Zagotoviti morate, da ima vsebina vse potrebne elemente.

- Razmislite o primernem vrstnem redu pomembnosti obravnavanih zadev.

- Ne dovolite bralcu, da bere med vrsticami, saj se tako izpostavljate na milost in nemilost njegovi domišljiji.

- Previdno uporabljajte številke: uporabljene številke morajo imeti podlago $\mathrm{v}$ dejstvih, zato se sklicujte na vire!

Predmet znanstvenega preučevanja so postale tudi značilnosti in načela jezika ter socialne interakcije, kot se uporabljajo za komuniciranje z elektronsko pošto in v novih medijskih okoljih. S pojavom družbenih omrežij nastajajo spremembe pri izražanju lastne identitete. $\mathrm{V}$ preteklosti je človek izražal svojo identiteto $\mathrm{z}$ osebnim kontaktom: $\mathrm{z}$ videzom, $\mathrm{s}$ strukturo govora, z glasnostjo in barvo glasu. Ob pojavu pisave se je človekov način izražanja identitete prilagodil in identiteta pisca se je pokazala $\mathrm{z}$ elementi, kot jih preučujejo grafologi. S pojavom elektronske pošte in družbenih omrežij človek ne more izražati svoje identitete na doslej obravnavne načine. To pa ne pomeni, da je ne izraža.

Aakhus in DiDomenico (2016) pravita, da socialna omrežja nikakor niso uničila jezika, pač pa se je jezik članov socialnega omrežja spet zgolj prilagodil tehničnemu okolju. V družbenih omrežjih se tako jezik kot načela komuniciranja prilagodita tehničnim lastnostim medija. Predmet preučevanja identitete sodelujočih v družbenih omrežjih zato v prvi vrsti ni sama vsebina sporočanja, pač pa to postajo nekateri drugi atributi komuniciranja, kot so:

- posameznikovi kriteriji za diferenciacijo različnih družbenih omrežij;

- način vstopanja posameznika v družbeno omrežje;

- pogostost uporabe družbenih omrežij napsloh;

- mehanizmi moderiranja vsebin znotraj skupine;

- način izražanja lastne aktivnosti posameznika;

- dinamika odzivanja na različne vsebine;

- dolžina sporočil; 
- pogostost uporabe različnih simbolov, kot so okrajšave, smeški, ipd.;

- drugo.

\section{Barve}

Prvi zapiski o proučevanju barv segajo v čas renesanse. Galileo Galilei (živel od leta 1564 do leta 1642) je pojmoval barvo kot sekundarno lastnost telesa. Primarne lastnosti naj bi bile tiste, ki jih je moč opredeliti s fizikalnimi veličinami (npr.: dolžina, masa, ...). Ljudje si fizikalnega ozadja barv zelo dolgo niso znali razložiti. Zato je dolgo časa veljalo prepričanje, da je barva sekundarna lastnost. Sekundarna lastnost pomeni, da gre zgolj za subjektivni odziv človeka na zaznave. Začetki proučevanja barv so tako povezani s paralelizmom (vzporednostjo dražljaja in barve). Tako pojmovanje se je obdržalo zelo dolgo. Šele, ko je bilo odkrito fizikalno ozadje barve, je bil tudi v psihologiji premagan princip paralelizma. Danes vemo, da je svetloba elektromagnetno valovanje. Različne barve imajo različne valovne dolžine. Barva je odvisna od valovne dolžine oziroma frekvence elektromagnetnega valovanja. Vidna svetloba ima valovno dolžino od 400nm do $800 \mathrm{~nm}$.

V psihologiji barv obstaja obilica eksperimentov, s katerimi psihologi proučujejo človekovo zaznavanje barv. Kot poroča Storozhuk (2010), so se znanstvena preučevanja psihologije barv začela okoli leta 1888 . Že od leta 1905 je poznano, da barve vplivajo na občutljivost zaznavanja drugih dražljajev, npr. zvočnih. Zaznana zelena barva povečuje slušno občutljivost, rdeča barva pa jo zmanjšuje. Barva svetlobe, ki jo človek zaznava, vpliva tudi nekatere druge spremembe $\mathrm{v}$ stanju obeh očes in $\mathrm{v}$ organizmu kot celoti.

Leta 1941 je bilo ugotovljeno, da osvetlitev enega očesa z zeleno svetlobo zniža očesni pritisk na drugem očesu (ki ni osvetljeno).

Raziskava občutljivosti zaznave okusa je leta 1944 pokazala, da okus sladkorja poveča barvno občutljivost na območju modro-zelene svetlobe in ga zmanjša na oranžno-rdečo svetlobo.

Že vsaj od leta 1947 je poznan fenomen reakcijskih časov. Časi, potrebni za zaznavo različnih barv so različni.

Leta 1948 je bilo ugotovljeno, da intenzivno intelektualno delo poveča občutljivost vizualne zaznave in tudi občutljivost zaznavanja vonja, zvoka, okusa in tipa.

Po teh odkritjih so bile $\mathrm{v}$ zadnjih desetletjih opravljene še številne druge raziskave. Storozhuk (2010) pravi, da pri odzivanju na vse zaznave sodeluje tudi vegetativni živčni sistem, na delovanje katerega zavestno ne moremo vplivati. Vegetativni živčni sistem vpliva na funkcionalno spreminjanje vseh tkiv, ne le na človekova čutila. Rezultati preučevanja zaznave barv kažejo na to, da je človekov organizem potrebno obravnavati kot celoto, saj tudi v resnici deluje kot celota. 
V zadnjem stoletju je bilo torej odkritih ogromno fenomenov v zvezi s človekovim zaznavanjem barv. $V$ tem poglavju bomo obravnavali zgolj nekatere:

- vpliv barv na reakcijske čase;

- dolgočasnost barv;

- fiziološki vpliv barv na človeka. ${ }^{7}$

Da se človek na zaznave različnih barv različno odziva, je že splošno znano. Tudi s poskusi je bilo dokazano, da se reakcijski časi na posamezne barvne tone gibljejo $\mathbf{v}$ obratnem sorazmerju $\mathbf{z}$ njihovimi valovnimi dolžinami. Reakcijske čase so merili na 20 zdravih osebah. Uporabili so 9 različnih barv svetlobnih dražljajev, ki so imeli različne valovne dolžine $(\lambda)$. Vsaka oseba je za vsak barvni dražljaj poskusila 50 reakcijskih časov. Reakcijski časi za dražljaje posamezne barve so bili:

$\begin{array}{ll}\text { modra }(\lambda=432 \mathrm{~nm}) & 220 \mathrm{~ms} \\ \text { zelena }(\lambda=495 \mathrm{~nm}) & 203 \mathrm{~ms} \\ \text { rumena }(\lambda=545 \mathrm{~nm}) & 193 \mathrm{~ms} \\ \text { rdeča }(\lambda=660 \mathrm{~nm}) & 176 \mathrm{~ms} \\ \text { bela } & 185 \mathrm{~ms}\end{array}$

Opravljeni so bili tudi poskusi reakcijskih časov na barvne dražljaje, ki se uporabljajo v prometu (rdeča, rumena, zelena). Ugotovitve so bile naslednje:

- Reakcijski časi pri dnevni osvetlitvi so krajši, kot v temi.

- Reakcijski časi so za rdečo barvo najkrajši, za zeleno pa najdaljši.

Zelo pogosta so raziskovanja dolgočasnosti oziroma kratkočasnosti barv. Kakor že sama beseda pove, gre za interakcijo (medsebojno vplivanje) med subjektivnim doživljanjem časa in zaznavanjem barve. Na podlagi poskusov je z veliko zanesljivostjo ugotovljeno, da ljudje pod vplivom različnih barv različno subjektivno doživljajo čas. Razlikovanje med dolgočasnimi in kratkočasnimi barvami sloni na stvarnih podlagah in se da natančno preveriti. Rumena in njej podobna rjava barva sta najbolj kratkočasni, siva in zelena pa najbolj dolgočasni.

Dvanajst poskusnih oseb (ki seveda normalno zaznavajo barve) so izpostavili vplivu določene barve (gledanje $\mathrm{v}$ steno pred seboj). Poskusne osebe niso vedele, za kakšen poskus gre. Edina inštrukcija je bila: "Sedite, sprostite se, glejte predse in nič ne mislite!" Poskus je trajal sedem minut. Po koncu tega časa so bile osebe vprašane o trajanju časa, ki so ga "presedele«. Povprečne vrednosti časov (odgovorov) poskusnih oseb za posamezne barve so bile:

$\begin{array}{ll}\text { bela } & 7,42 \text { minut } \\ \text { rumena } & 6,58 \text { minut } \\ \text { modra } & 7,25 \text { minut }\end{array}$

${ }^{7}$ Opisi vseh treh fenomenov, so povzeti iz virov: Trstenjak, 1996 in Trstenjak, 1978. 


$\begin{array}{ll}\text { rdeča } & 8,10 \text { minut } \\ \text { siva } & 10,10 \text { minut } \\ \text { zelena } & 9,10 \text { minut } \\ \text { rjava } & 6,83 \text { minut }\end{array}$

Na podlagi številnih poskusov v različnih laboratorijih in bolnicah je mogoče sestaviti razpredelnico psiholoških in fizioloških vplivov posameznih barv na človeka:

- Rdeča barva zvišuje mišično napetost, zvišuje krvni pritisk in pospešuje cirkulacijo krvi in dihanje. Velja za duševni stimulans.

- Oranžna barva pospešuje prebavo in utrip srca, ne da bi zvišala krvni pritisk. Utegne utrujati.

- Rumena barva je stimulans za oči, torej tudi za živce.

- Zelena barva znižuje krvni pritisk in razširja kapilare. Je ugodna za zdravljenje mentalnih bolezni, živčne utrujenosti, ni pa primerna za lajšanje vseh nevrotičnih stanj.

- Modra barva znižuje krvni in muskulaturni pritisk, pomirja utrip in upočasnjuje dihalni ritem.

- Vijolična okrepčevalno vpliva na srce in pljuča (Trstenjak, 1996).

Poleg fizioloških pa naj bi imele barve tudi psihološke učinke na človeka:

- Rdeča barva je barva ognja in krvi, izraz življenja in moči. Neločljivo je povezana s strastjo, vročino in borbo.

- Modra je barva globokega ledu, čustveno jo povezujejo s hladno daljino prostora in njegovo neskončnostjo.

- Rumena je najsvetlejša med vsemi barvami. Je barva sonca, izraz bleska in živahnosti.

- Oranžna je mešanica rdeče in rumene, zato združuje silnost rdeče in živahnost rumene.

- Zelena je mešanica modre in rumene. V sebi združuje veselje in mir.

Kot piše Sherin (2011), je barva eno izmed najmočnejših orodij oblikovalcev. Pri odločanju ljudi o nakupu nekega izdelka je prav barva izdelka ali embalaža lahko ključen dejavnik.

Sherin (2011) povzema naslednje atribute, ki so pomembni za oblikovalce:

Odtenek je zgolj drug izraz za barvo. Vsako barvo je s svetlobno prizmo možno razstaviti na primarne barve: modro, rdečo in rumeno. Odtenek je odvisen od deleža posameznih sestavin. Človeško oko naj bi bilo sposobno ločiti 10 milijonov odtenkov.

Nasičenost ali tudi intenzivnost je moč ali čistost brez dodajanja bele ali črne. Bolj nasičen odtenek je močnejši, bolj živ ali svetlejši. Otopele barve se zdijo, kot da so razredčene. Intenzivne barve se uporabljajo za doseganje večjih vizualnih učinkov. 
Temperatura barve se meri po posebnem postopku v Kelvinih. Nižja temperatura barve pomeni toplejšo svetlobo (rumeno ali rdečo). Višja barvna temperatura običajno kaže hladnejše tone (zeleno in modro).

Vrednost je relativna svetlost ali temnost barve. Vrednost je $\mathrm{v}$ oblikovanju eden od najboljših načinov za doseganje kontrasta. Je pomembno orodje za dodajanje poudarka in za vzpostavitev vizualne hierarhije v kompoziciji.

Parametri modela predstavlja poseben sistem označevanja barv, ki se uporablja za usklajevanje barv $\mathrm{v}$ različnih delih sistema oblikovanja, tehničnega razvoja, nabave, proizvodnje, distribucije in servisiranja proizvodov. V Evropi se uporablja RAL sistem parametrov barv. RAL izhaja iz nemškega sistema, ki ga je leta 1927 postavil ReichsAusschuß für Lieferbedingungen und Gütesicherung. Na začetku je bilo standardiziranih samo 40 barvnih odtenkov. Število standardiziranih barvnih odtenkov se je prvič povečalo leta 1930, od takrat se stalno dopolnjuje.

\section{Neverbalno komuniciranje}

Ko se človek z nekom pogovarja, izgovorjenih besed ni mogoče obravnavati ločeno od ostalih simbolov. V pogovoru sodeluje človekovo telo kot celota. Da je človeštvo prišlo do znanstvenih dokazov o tem, je rabilo tisočletja.

O neverbalnem komuniciranju, zlasti o »govorici telesa « je bilo v preteklosti zelo veliko zapisanega. Kot navaja Knapp (2013), razprave o neverbalnih simbolih najdemo že v antiki. O tem je pisal Charles Darwin in drugi avtorji. Preučevanje neverbalnega komuniciranja je postalo še posebej popularno po koncu II. svetovne vojne. V ospredju družbene pozornosti časa po koncu vojne je bilo hrepenenje ljudi po bolj "odprti" in bolj transparentni družbi. To je bilo tudi obdobje razcveta televizije. Takratnemu času primerne so bile tudi vsebine preučevanja neverbalnega komuniciranja. Nanašale so se na simbole, ki so povezani z medosebnimi odnosi. Ti simboli so bili zlasti:

- govorica obraza;

- proksemika;

- drža in hoja ljudi;

- gestika to je kretnje rok, nog in glave;

- mimika, to je izraz obraza in oči.

\section{Govorica obraza obsega:}

- gibe glave;

- fiziognomiko (gibi obraznih mišic kot tudi sama oblika glave). 
Proksemika preučuje položaj in gibanje ljudi v prostoru. V širši javnosti so s tem v zvezi zelo poznani človekovi prostorski pasovi:

- Intimni pas je prostor, ki ga človek varuje kot svojo lastnino in le ljudje, na katere je nekdo čustveno navezan, smejo vstopiti v ta prostor.

- Osebni pas je razdalja, s katere se pogovarjamo z poznanimi ljudmi.

- Socialni pas je razdalja, ki jo ohranimo pri srečanjih z neznanimi ljudmi.

- Javni pas je razdalja, ki jo zavzamemo od ljudi, kadar nagovorimo večjo skupino.

V primeru vdora v človekov intimni pas, se v telesu sprožijo nekatere reakcije (npr.: srčni utrip, izločanje nekaterih hormonov, ...).

Z držo in hojo ljudje izražamo sporočila, kot npr.: duševno pripravljenost, pripravljenost še naprej sodelovati, seksualno vsiljivost, namig končati pogovor, možatost ali samozavest.

Geste so gibi rok, nog, glave in obraznih mišic in oči, ki jih delamo podzavestno

Mimika so kretnje ust oziroma mišic okoli ust. Z njimi se smejimo, izražamo žalost, jezo, strah in druga čustva.

Skozi zadnja desetletja so tako nastali številni zapisi predvsem o pomenu posameznih neverbalnih simbolov. Kot pravi Knapp (2013) je bil interes javnosti za to tematiko izjemno velik. Ljudje so si želeli najti »čustveno resnico«, ki je morda izražena v neverbalnih simbolih. Nekateri so celo menili, da področje človekovega nebesednega sporočanja sodi med mejne znanosti. Področje nebesednega sporočanja je $v$ nekem obdobju v »znanstveni« in splošni literaturi v nekaterih delih dobilo skoraj mistične razsežnosti. Tipična primera sta npr.: področje fiziognomike in preučevanje človekove avre. Tako za en kot za drug pojav $\mathrm{v}$ zapisih najdemo tudi interpretacije, ki niso znanstveno utemeljene. Avra je sicer pojav, ki ga je možno fotografirati s Kirianovo kamero. Vendar nekateri opisi avre v tem nimajo osnove. Podobno velja za neznanstvene in pogosto zelo splošne opise povezovanja fiziognomike človekovega obraza $\mathrm{z}$ osebnostjo.

Razlog takemu stanju je bil tudi v okoliščini, da znanost še do nedavnega ni razpolagala s tehničnimi sredstvi, ki bi omogočala empirično raziskovanje nekaterih fenomenov, vezanih na neverbalno komuniciranje. Predvsem pa je treba izpostaviti pomanjkljivost opisovanja pomena posameznih oblik človekovega izražanja zgolj z vidika posameznosti, torej brez povezovanja z ostalimi oblikami človekovega izražanja.

$\mathrm{V}$ zadnjih dvajsetih letih je prišlo do drugačnega pojmovanja neverbalnega komuniciranja. S pojavom sodobnih avdio-vizualnih sredstev, orodij za biometriko, zmogljivih računalnikov in novo programsko opremo, je znanost dobila nova orodja in s tem možnost, da so se ponovno ovrednotijo izkustvena spoznanja zadnjih desetletij. Nekatere dotedanje trditve so se sicer potrdile tudi z novejšimi raziskavami. Prišlo je do 
številnih novih odkritij. Znanost je ovrgla tudi nekatere stereotipe. Zaradi velikega napredka znanosti je pri preučevanju neverbalne ga komuniciranja treba stalno slediti novejši literaturi.

Hall-ova (2013) pravi, da so neverbalni simboli vsa tista človekova potencialno informativna vedenja, ki niso zgolj jezikovne narave in se praviloma pojavljajo vzporedno z govorom. Neverbalno komuniciranje se navzven izraža $v$ fenomenih, ki jih preučujeta medicina in psihologija. Nekateri neverbalni simboli imajo tudi širše dimenzije. Tak primer je simbolno izražanje moči in dominance, ki je predmet preučevanja sociologov.

Kot pravi Esposito (2007) so glavne teme sodobnega preučevanja značilnosti neverbalnega komuniciranja $\mathrm{v}$ iskanju nedvoumne povezanosti z:

- identifikacijo osebe;

- iskanjem družbeno-kulturnega porekla osebe;

- osebnostnimi lastnosti.

Po drugi strani je predmet preučevanja neverbalnih simbolov tudi v iskanju edinstvenosti ravnanja posameznikov. Izziv sodobne znanosti je, da najde načine, kako na podlagi neverbalnega komuniciranja nedvoumno identificirati osebo. To vprašanje ima $\mathrm{v}$ sedanjem času globalnega terorizma poseben pomen tudi $\mathrm{z}$ vidika zagotavljanja varnosti. Tudi znanost pomaga iskati tista individualna ravnanja, ki bi lahko kazala na nevarno obnašanje.

Campbell (2007) neverbalne simbole klasificira na:

- tiste, ki se navezujejo na obstoječ diskurz komuniciranja;

- tiste, katerih glavna naloga je, da nam znotraj obstoječega diskurza komuniciranja oziroma znotraj konteksta sami po sebi dajo novo informacijo.

Kendon (2007) je preučeval človekove geste in ugotovil naslednje:

- Že od 18. stoletja obstaja ideja, da bi geste lahko pomenile prvo obliko sporazumevanja med ljudmi.

- Študije, kako so geste organizirane glede na govor, so pokazale, da sta govor in gesta neločljiva vidika enega samega osnovnega procesa.

- Govorno komuniciranje in geste so v interakciji.

- Popolno razumevanje govornega komuniciranja zahteva, da se upoštevajo tudi vidne telesne dejavnosti govornika.

Do podobnih spoznanj je prišel Campbell (2007), ki je je preučeval dinamiko uporabe elementov govora. Imenoval jih je »zvočna pokrajina«. Elementi »zvočne pokrajine« v slovenskem jeziku so npr. besede: $» j a \ll, » n e \ll, » m h h h m «, » p a c ̌ \ll$ ipd. Na podlagi analize posnetih pogovorov z računalniškim programom, izdelanem po posebnem algoritmu, je bilo ugotovljeno, da se zvočne pokrajine v različnih dialogih pomembno razlikujejo, tako 
po dinamiki, kot po uporabi tipičnih besed. Razlike v dinamiki uporabe elementov zvočne pokrajine dajo novo informacijo. Ta lahko odraža osebni odnos govornika do sogovornika, osebnostne lastnosti ali kulturne posebnosti, interes udeleženca za pogovor in vrsto sodelovanja v diskurzu.

Nadgradnjo te raziskave predstavljajo spoznanja Esposito-ve in Marinaro-ve (2007) glede uporabe premorov v govoru. Avtorici sta s pomočjo računalniške spektralne analize govora in video analize raziskovali premore $\mathrm{v}$ govoru. Za premor $\mathrm{v}$ govoru sta šteli vsako obdobje tišine, ki je daljše od $120 \mathrm{~ms}$. Avtorici navajata predhodne raziskave na tem področju. Te so pokazale, da imajo premori lahko številne komunikacijske funkcije, kot so: vzpostavitev napetosti, dvig pričakovanja, poudarek, stopnjo spontanosti. Lahko pa odražajo tudi spol, starost izobrazbo in socialno-ekonomsko poreklo. Ugotovili pa sta, da je pri otrocih kar 93\% premorov v govoru popolnoma predvidljivih. Pri odraslih je predvidljivih premorov $78 \%$. S statistično analizo sta dokazali zelo veliko stopnjo "pokrivanja med govornimi pavzami in kretnjami rok. Menita, da imajo geste podobno funkcijo kot pavze.

S pomočjo sodobnih orodij za biometriko, snemanje ter računalniško analiziranje gibanja oči in obraznih mišic so bile opravljene tudi analize odzivanja oči in obraznih mišic. ${ }^{8}$

Tudi ta spoznanja dokazujejo, da človekovega neverbalnega izražanja ni mogoče obravnavati ločeno od verbalnega. Spoznanja so podobna ugotovtvam psihologov, ki so preučevali zaznavanje barv in na osnovi interakcij pri istočasnem zaznavanju različnih simbolov prav tako ugotovili, da je sistem človekovega zaznavanja, percepcije in semantike treba obravnavati kot eno celoto.

${ }^{8}$ Več o tem glej v: Esposito, A., et al. (2007): Fundamentals of Verbal and Nonverbal Communication and the Biometric Issue. IOS Press, NATO Security Through Science Series, Amsterdam. 
Teoretične osnove komuniciranja 


\section{SPREJEMNIK}

\section{Procesi zaznavanja}

Človeško telo s svojimi čutili vsako minuto zazna okoli 10.000 zaznav. Zaznave imajo različne pojavne oblike in so: vizualne zaznave, zaznave zvoka, vonja, temperature, okusa, bolečine in prostorskega položaja telesa (ravnotežja). Zaznave so hkratne. Zato je človeško telo pri zaznavanju treba obravnavati kot enovito celoto.

Storozhuk (2010) ugotavlja, da je zaznavanje stalen proces delovanja celotnega človeškega telesa. Človeško oko tako spremeni svoj položaj vsakih $150-200 \mathrm{~ms}$. Torej se v očesu vsak dan pojavi 216.000 vizualnih zaznav. Približno toliko je tudi zaznav sluha in vonja. Več je le zaznav gibanja sistema človekovih mišic.

Procesi na strani sprejemnika so:

- vstop dražljaja prek senzorjev (čutil):

- filtriranje zaznav s strani čutil;

- prenos zaznanega dražljaja v možgane;

- percipiranje in

- mentalna obdelava.

Procesi zaznavanja na strani sprejemnika so med komuniciranjem so zelo kompleksni. Zaporedje procesov na strani sprejemnika prikazuje slika 4.

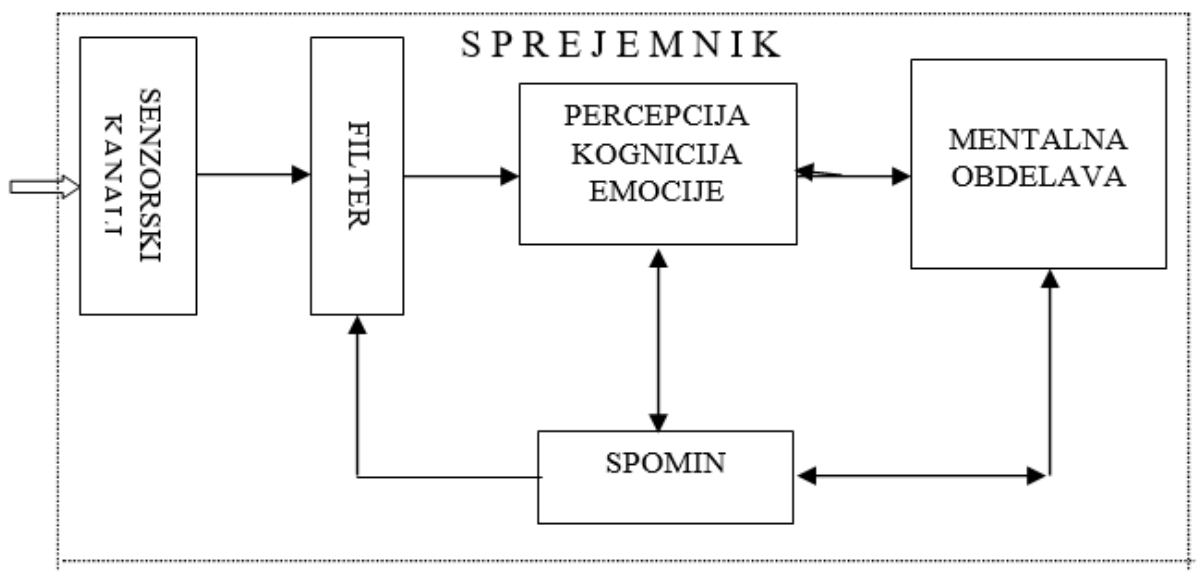

Slika 4: Zaporedje procesov na strani sprejemnika. 
Fizikalno gledano dražljaji iz fizičnega okolja najprej dosežejo čutila. Vseh dražljajev iz čutila niso sposobna zaznati, ker imajo omejitve. Človek zaznava zvoke samo v frekvenčnem pasu OD $16 \mathrm{~Hz}$ do $20 \mathrm{kHz}$. Oko je sposobno zaznav v tako imenovanem vidnem spektru svetlobe. Vidna svetloba ima valovne dolžine od $400 \mathrm{~nm}$ do $800 \mathrm{~nm}$. Prav tako ima človek omejeno sposobnost zaznav vonja. Oko ne zazna svetlobe izven vidnega frekvenčnega spektra, uho ne zazna zvokov, ki imajo prenizke ali previsoke frekvence, ipd. Zaznane dražljaje čutila pretvorijo v signale živčnemu sistemu. Del teh signalov takoj izloči živčni sistem, del pa jih izločijo možgani. Gre za:

- izločanje zaradi omejitev čutil in živčnega sistema ter

- zavestno in podzavestno izločanje $\mathrm{v}$ možganih.

Storozhuk (2010) pravi, da o tem, katere zaznave bodo izločene, v prvi vrsti že na nezavedni ravni odloči telo samo.

$\mathrm{V}$ določenem časovnem intervalu je človek $\mathrm{v}$ nadaljnjo obdelavo sposoben sprejeti le omejeno število zaznav. Po drugi strani pa človek posamezne zaznave zavestno izključuje, ker se jim na zavedni ali nezavedni ravni želi izogniti.

Razlogi za izločanje že sprejetih zaznav so:

- stereotipi;

- utrujenost oziroma stres;

- vpliv snovi, ki vplivajo na delovanje možganov (alkohol, droge, nekatere vrste zdravil, ipd.);

- komunikacijska obremenitev;

- drugo.

Število filtriranih zaznav se še dodatno poveča ob utrujenosti oziroma stresu. $\mathrm{Ob}$ utrujenosti ali stresu se namreč človekove psihofizične sposobnosti zelo zmanjšajo. Zmanjša se tudi sposobnost čutil, da bi zaznala šibke dražljaje.

Pomemben dejavnik, ki vpliva na filtriranje, je komunikacijska obremenitev.

Komunikacijska obremenitev (Vila 1994) je funkcija:

- Števila odločitev, ki morajo biti sprejete v določenem časovnem intervalu;

- potrebne hitrosti, da se obdela določen informacijski vložek;

- zahtevane kakovosti obdelave informacij;

- predvidljivosti prihajanja sporočil;

- predvidljivosti vsebine sporočil.

Komunikacijska obremenitev je torej sorazmerna s kompleksnostjo in pogostostjo sprejetih sporočil. 
Človek zbrane in filtrirane zaznave percepira. Pride tudi do kognicije (spoznavanja) in do emocij (čustev). V svojih možganih na ta način ustvarja ogromno bazo podatkov. Ta baza je osnova za presojo ljudi, stvari, procesov in pojavov.

\section{Percepcija}

Beseda »percepcija « je latinskega izvora (percipere). Percepcija je predmet znanstvenega preučevanja medicine in psihologije že od 19. stoletja dalje. Percepiramo zaznave iz fizičnega okolja.

Medicina preučuje biološke mehanizme, odgovorne za percepcijo iz vidika delovanja organov. Predmet preučevanja je relacija med zaznanim dražljajem in odzivom organizma na dražljaj.

Psihologija pa se osredotoča na ostale faktorje, ki so za percepcijo prav tako pomembni. Ti faktorji so npr.: kontekst, izkušnje, razlike med posamezniki, pričakovanja, predhodno znanje, spomin, idr.

Iz medicinskega stališča percepcija pomeni zavestno duševno registracijo zaznanih senzoričnih dražljajev kot rezultat stimulacije čutil. Je nadčutna zaznava, znanje, odgovor, misel ali namen. (Miller, 2003).

Proces percepcije iz medicinskega gledišča poteka tako, da senzorični organi preoblikujejo prejeto vhodno energijo zaznanega senzoričnega dražljaja (npr. zaznano svetlobo, zaznan zvok, kemične dražljaje) v aktivnosti živčevja. Proces se imenuje transdukcija. »Signali« se iz čutil preko živčevja prenašajo v možgane. V možganih se mentalno obdelujejo. Na podlagi zaznanih dražljajev in mentalne obdelave v možganih nastane »ponovna vzpostavitev«. Ponovna vzpostavitev se imenuje percepcija. (Goldstein, 2009)

Psihologi postavljajo nekoliko širšo definicijo. Percepcija je kognitivni proces dodeljevanja nalepk na zaznan dohodni signal iz sveta izven človeškega organizma, v primeru, če ga človek slušno, vidno, ali na kateri koli drug način zazna. (Tatham, Morton, 2011).

To torej pomeni, da percepcija vključuje več procesov, kot zgolj »mehanistično « zaznavanje dražljajev iz okolja, katere medicina zna vsaj do določene mere pojasniti z zakoni fizike in biokemije. Taka definicija je popolnoma logična, saj »mehanistično« gledano percepcija že zaradi fizionomije človeškega telesa ne more biti neposredna preslikava realnosti v človekove možgane.

Percepcija je torej tesno povezana tako z zaznavanjem ( $v$ dobesednem pomenu te besede), kot s spoznavanjem (s procesom kognicije). 
Percepcija je:

- implicitna percepcija, ki je nezavedna zaznava nečesa, ne da se na zavedni ravni tega sploh zavedamo;

- eksplicitna percepcija, ki povzroči zavedanje. (Pashler, 2013).

V medicini so poznane raziskave percepcije vizualnih zaznav. Človek objekt zazna v več dimenzijah. Zazna velikost, obliko in barvo objekta. Razlika zgolj v eni dimenziji sicer istega objekta lahko popolnoma spremeni percepcijo. Barva in kontrast predmeta vplivata na percepcijo. (Goldstein, 2010). Ta pojav ima sicer povsem fizikalno ozadje. Vemo, da je svetloba elektromagnetno valovanje, barva pa je odvisna od frekvence. Različne barve v očesu povzročijo različen signal, ki gre po živčevju v možgane.

Psihologi pogosto raziskujejo percepcijo na podlagi odzivov na zvočne dražljaje. Razlogov, da se v psihologiji percepcija pogosto raziskuje prav na primeru zvočnih dražljajev, je več:

- Skozi evolucijo je človek razvil organe tako za produkcijo, kot za zaznavanje zvoka. Tatham in Morton (2011) celo trdita, da se je pri človeku govor razvil zato, da se percepira.

- Zvočne dražljaje je pri poskusih relativno preprosto izolirati od prav vseh ostalih dražljajev iz okolja.

- Merjenje frekvenčnega spektra zvoka je relativno preprosto.

Tatham, Morton (2011) navajata, da v zvezi s percepcijo zvoka obstajajo tri vrste fundamentalnih stališč:

- Direktni realizem izhaja iz predpostavke, da zavedanje zunanjega sveta neposredno povzročijo zaznave, pridobljene od čutil (v konkretnem primeru zaznava zvoka).

- Indirektni realizem izhaja iz predpostavke, da zavedanja zunanjega sveta neposredno ne povzročijo zaznave, pridobljene od čutil (v konkretnem primeru zaznava zvoka) pač pa interakcija med: informacijami iz čutil, informacijami, ki jih ima človek že v spominu in mentalne interpretacije zunanjega sveta.

- Idealizem je skrajni pristop, ki trdi, da zunanji svet sploh ne obstaja in da se zavedamo le idej priklicanih $\mathrm{v}$ naših možganih.

Teoriji direktnega in indirektnega realizma je možno kombinirati. S poskusi človekovih reakcij na dražljaje zvoka je bilo nedvomno potrjeno, da se človek odzove na zvočne dražljaje:

- kadar so ti popolni in če $\mathrm{v}$ zvočnem dražljaju ni integrirana nobena motnja;

- tudi če so dražljaji precej nepopolni oziroma če je v zvočnem dražljaju integrirana tudi zelo očitna motnja. 
Človek se torej odziva;

- neposredno na podlagi interakcije med zaznavami iz čutil,

- pa tudi na podlagi informacij, ki jih ima človek že v spominu v povezavi z mentalno interpretacijo zaznave zunanjega sveta.

Petrone in soavtorji (2016) na podlagi raziskav percepcije zvoka ugotavljajo, da se v možganih shrani samo »povzetek« tistega, kar človek zazna s čutili. Mnenja o tem, kako nastane »povzetek«, pa so v znanosti deljena. Petrone in soavtorji (2016) sicer navajajo tri teorije preučevanja percepcije in pomnjenja govornih dražljajev. V znanosti pa prevladuje teorija abstrakcije. Gre za poskuse, katere je opravljal Halle leta 1986 in ugotovil, da $\mathrm{v}$ procesu mentalne obdelave in ponovne vzpostavitve nastalih zvočnih spodbud pride do abstrakcije zaznanih dražljajev. Petrone in soavtorji (2016) navajajo primer, da se pri učenju nove besede pri pouku tujega jezika praktično nikoli nismo zapomnili večine najpomembnejših akustičnih lastnosti, ki so bile prisotne v zvočnem signalu, ki so pri učenju nove besede prišla v naša ušesa. Ne spomnimo se kakovosti prenosa govora osebe, ki nas je učila novo besedo, ne spomnimo se šumov, niti hitrosti, s katero je bila beseda izrečena. Zapomnimo si zgolj besedo in njen pomen. Poudariti pa je treba, da ta teorija doživlja tudi številne kritike.

Percepcije ne preučujeta zgolj medicina in psihologija, pač pa tudi filozofi. Pri tem filozofi ločijo tri vrste objektov percepcije:

- objekti, ki jih človek zaznava neposredno s čutili in z njimi ni v nobenem odnosu;

- objekti, ki jih človek zaznava neposredno s čutili in so od njega tudi odvisni, oziroma je človek z njimi v nekem odnosu;

- objekti, ki so popolnoma neodvisni od človekovega uma; med predmetom in človekom v fizičnem svetu ni prav nobene povezave in jih človek neposredno sploh ne zaznava.

Filozofi trdijo, da do percepcije lahko pride brez neposrednega zaznavanja objekta s čutili. Zadošča, da se ljudje z nečem zavestno seznanijo. Pri tem je po njihovem dovolj, da spoznajo zgolj določeno lastnost. ${ }^{9}$

Tudi v medicini obstajajo nekateri dokazi za to, da za percepcijo ni nujen obstoj senzorja oziroma zaznava dražljaja. Ljudje, ki so jim amputirali določen del telesa, pogosto še vedno čutijo bolečino v tem delu telesa, čeprav čutila tam ne obstajajo več. (Goldstein, 2010)

\footnotetext{
${ }^{9}$ Povzeto po: Brewer, 2011.
} 
Bistvo percepcije je torej naslednje:

- Percepcija je človekovo subjektivna interpretacija vsega, kar človek zaznava na zavedni in nezavedni ravni. Je miselna vizualizacija $\mathrm{v}$ obliki »mentalne slike« zaznanega. Lahko so zgolj misli o razumevanju zaznanega.

- Na podlagi dražljaja (ali vsaj obstoja nekega dražljaja) pride najprej do prenosa dražljaja $\mathrm{v}$ možgane in nato do biokemičnih procesov $\mathrm{v}$ možganih, ki povzročijo percepcijo.

- Za percepcijo je nujna zaznava ali vsaj obstoj nekega dražljaja.

Med ljudmi obstajajo razlike:

- $\quad \mathrm{v}$ fizionomiji čutil in posledično $\mathrm{v}$ sposobnostih zaznavanja;

- v biokemičnih in drugih procesih v živčevju in možganih.

Dokazano je, da pri človeku na percepcijo vplivajo tudi geni. Petrone in soavtorji (2016) navajajo in opisujejo številne raziskave od leta 1983 dalje, ki so to potrdile.

Razlike med ljudmi v percepciji istega dražljaja niso zgolj posledica razlik v fizionomiji in $\mathrm{v}$ genih. Nastanejo tudi zato, ker so med ljudmi pri presoji ali ocenjevanje nečesa razlike v tem, kaj posamezniki uporabljajo kot »standard«, ali »referenčni okvir«. (Aronson et al. 2010).

Pashler (2013) navaja, da ljudje zaznave kategoriziramo oziroma razvrščamo. Gre za različno odzivanje glede na tipologijo predmetov ali dogodkov v ločene razrede oziroma kategorije. Ta sposobnost možganov je vitalnega pomena za človekovo preživetje.

Na percepcijo vplivajo tudi že akumulirani dražljaji (npr.: pretekle izkušnje). Dokazano je, da se ljudje razlik v percepciji dražljajev lahko tudi naučijo (npr.: degustatorji, glasbeniki, idr.).

Posledica vsega tega je, da isti dražljaj ljudje lahko različno percepiramo. Percepcija torej ni neposreden, objektiviziran »zapis« vsega zaznanega v človekovih možganih, pač pa gre za subjektivno mentalno interpretacijo.

\section{Kognicija}

Kognicija je proces spoznavanja na osnovi:

- zaznav dražljajev iz fizičnega sveta in

- interakcij posameznika s fizičnim in s socialnim okoljem.

Kognicija z vključitvijo socialnega okolja v proces spoznavanja pomeni več, kot je proces percepcije. Poleg zaznav so za kognicijo ključnega pomena tudi:

- interakcije z različnimi posamezniki znotraj socialnega okolja; 
- interakcije posameznika z socialnim okoljem kot celoto.

Nova spoznanja oziroma nove kognicije, ki jih človek pridobi v spomin, ob vsakih novih zaznavah vplivajo na percepcijo le teh.

V procesu kognicije gre po Marcum-u (2014) za zaporedje več procesov:

1. Biološki proces na ravni posameznika poteka $z$ zaznavo $v$ okviru sistema človekovih čutil, prenosa dražljajev preko živčevja v možgane in percepcija.

2. Kognitivni proces na individualni ravni posameznika, na katerega vpliva: zaznava, vnaprejšnja človekova mišljenja ter časovni, prostorski ter situacijski dejavniki okolja.

3. »Podaljšek« kognitivnega procesa; poleg časovnih, prostorskih ter situacijskih dejavnikov (fizičnega in socialnega) okolja pride še do interakcij v socialnem okolju. Interakcije v socialnem okolju (npr.: med člani skupine) so zelo kompleksne. Pride do povratnih zank med člani socialnega okolja (skupine). Povratne zanke so lahko pozitivne ali negativne, kar pomeni, da zaradi njih lahko pride do »ojačitev« ali do »slabitev« kognicij.

Marcum (2014) pravi, da na individualni ravni posameznika kognicija brez zaznave sploh ni možna. Našteva pa šest dejavnikov okolja, ki vplivajo na output procesa kognicije

- Situacijski dejavnik okolja: ista zaznava (isti input v proces kognicije) $\mathrm{v}$ različnih situacijah v okolju lahko povzroči popolnoma različne outpute.

- Časovni komponenta pomeni, da ista zaznava v različnih časovnih obdobjih lahko povzroči popolnoma različne kognicije.

- Efekt »razbremenitve« - za sklepanje zaključkov se včasih v množici zaznav pojavi točno tista, ki si jo človek želi. Na osnovi te zaznave lahko sklene popolnoma napačen zaključek.

- Sprožilni mehanizem - vključitev okolja je potrebna, da se proces spoznavanja nečesa na ravni posameznika sploh začne. Brez vključitve okolja zaznava na ravni posameznika sicer obstaja, vendar ne pride do kognicije.

- Kognicije je lahko posledica dosedanjega delovanja ali obnašanja.

- Kognicija je lahko tudi prilagoditev na okolje.

»Podaljšek« kognitivnega procesa na ravni posameznika pomenijo interakcije med člani socialnega okolja. Psihologi ločijo: kognicijo na ravni posameznika in kognicijo na ravni skupin. Skupine imajo kognitivne sposobnosti, ki presegajo enostavne agregacije kognitivnih zmožnosti posameznikov.

Interakcije med posameznikom in socialnim okoljem vplivajo na kognitivni proces na individualni ravni. Lahko pa pride tudi do kolektivne kognicije. Poenostavljeno povedano kolektivna kognicija pomeni »prepis« spoznanj in stališč med člani skupine oziroma v družbi kot celoti. Kot povzema De Risio (2014) je ključnega pomena za razumevanje fenomena kolektivne kognicije to, da pri članih socialnega okolja pogosto lahko opazimo enak način dojemanja zaznav. 
Fenomen kolektivne kognicije opisuje več teorij. Brower in Nurius (1993) opisujeta »kognitivno-ekološki model«. Bistvo te teorije je v trditvi, da je primarna motivacija vrst, tudi ljudi, praviloma $\mathrm{v}$ tem, da ostanejo in preživijo v istem okolju. Pri človeku imamo opravka s fizičnim okoljem in s socialnim okoljem. Da bi se vrste sploh lahko ohranile same po sebi, morajo za svoje potrebe uporabljati okolje, ne da bi okolje uničile. Skozi evolucijo so vrste razvile ravnanja in najboljše možne odzive na različne situacije v okolju.

Pri tem se je skozi evolucijo razvila tudi sposobnost pridobivanja, pomnjenja in uporabe izkušenj. Ta sposobnost pomeni, da je bitje ob zaznavi določenega dogodka sposobno razviti mišljenje. Poznani so številni primeri uporabe izkušenj za odzivanje na zaznave iz okolja. Prilagoditveni procesi vrst na okolje po eni strani bogatijo okolje, po drugi strani pa povečajo zmožnost vrst za preživetje. Bistvo sposobnosti uporabe izkušenj pri nekaterih živih bitjih je v tem, da je živo bitje na podlagi:

- predhodno že zaznanih dogodkov, praviloma v fizičnem okolju in

- interakcij iz preteklosti,

takoj sposobno povezati zaznan dogodek v fizičnem svetu z dogodkom, ki bo sledil.

V primerih takih zaznav se bitja, ki imajo to sposobnost, navadno v realnem času odzivajo po »shemah«. Ko se na semaforju npr. prižge rdeča luč, se npr. takoj ustavimo.

Sheme so torej mentalne podobe, ki nekaterim bitjem omogočajo shraniti in katalogizirati veliko informacij o preteklih dogodkih, znanje o njih ter koncepte odzivanja. Sposobnost priklicati shemo iz spomina je v določenih situacijah temelj sposobnosti preživetja.

Vendar pa poleg fizičnega okolja obstaja tudi socialno okolje. Da bi človek lahko preživel $\mathrm{v}$ socialnem okolju in bil z njim v interakciji, je z ostalimi člani socialnega okolja moral na nek način komunicirati. Skozi evolucijo se je razvila medsebojna izmenjava simbolov. Simboli (npr.: slišane besede v razvoju govora) za človeka predstavljajo zaznave, tako kot katerekoli druge zaznave iz okolja. Tudi na podlagi teh zaznav pride do percepcij in kognicij, podobno, kot če bi prišlo do zaznave kateregakoli drugega objekta.

V procesu komuniciranja med ljudmi v človekovih razmišljanjih nastanejo tudi »socialne sheme«. Kognitivno-ekološki model opisuje nastanek socialnih shem na podoben način, kot sposobnost pridobivanja, pomnjenja in uporabe izkušenj.

Socialne sheme nastanejo in delujejo na principielno enak način, kot izkušnje. Vir zaznav v procesu nastajanja socialnih shem pri ljudeh ni nek zaznan dogodek v fizičnem okolju. Vir zaznave je informacija iz socialnega, okolja. Pogoj za nastanek socialne sheme je obstoj informacije od nekoga ali od nečesa, katerega ima prejemnik za zanesljivega, verodostojnega, zaupanja vrednega, ipd. Sposobnost ljudi je, da svoje sheme med seboj delijo. Medsebojna distribucija shem se lahko dogaja neposredno z medsebojnim komuniciranjem in medčloveškimi odnosi. Lahko pa se dogaja tudi posredno, ko 
opazujemo, kako se odzivajo drugi. Na podlagi socialnih shem si ljudje razlagajo dogodke in se po shemah nanje odzivajo.

Kot povzema De Risio (2014), bi kolektivna kognicija pri človeku lahko izvirala iz bioloških mehanizmov učenja s posnemanjem pri dojenčkih in pri otrocih.

\section{Emocije}

Emocije oziroma čustva in razpoloženja so odzivi človeškega telesa na zaznave iz okolja. Nastanek čustev je povezan z zaznavo in s preteklimi izkušnjami. Predpogoj za pojav čustva in razpoloženja je izpostavljenost izkušnji ali situaciji, ki v nevrološkem sistemu predstavlja sprožilno zaznavo za čustvene odzive.

Področje človekovega čustvovanja raziskujejo nevroznanost, psihologija in sociologija.

Biološki mehanizem nastanka človekovih čustev je dokaj dobro raziskala nevroznanost. Kot navaja Ingram (2015), ki se sklicuje na številne novejše znanstvene dokaze, so čustva posledica delovanja možganov, vendar niso povezana s človekovo inteligenco. Čustva nastanejo v predelu možganov, imenovanem »amygdala«. Ljudje, ki so v nesrečah doživeli poškodbe tega dela možganov, se na zaznave čustveno ne odzivajo. Ingram (2015) meni, da gre pri nastanku čustev za refleks in da se čustvenega odzivanja ni mogoče naučiti, Vendar pa je ta refleks, zlasti njegova intenzivnost, povezan z izkušnjo. Glede na človekove izkušnje je med ljudmi refleks lahko zelo različen.

Nekateri psihologi karikirajo, da čustev sploh ne »čutimo«, pač pa jih samo »mislimo«. Misli so zgolj en del čustev. So mentalni odziv na zaznane dražljaje. Odziv na zaznave, ki sprožijo pojav čustva, pa ni samo miseln. Odzove se tudi človekovo vegetativno živčevje. To povzroči še druge odzive in spremembe v človekovem telesu. Iz vsakdanjega življenja poznamo odziv obraznih mišic (npr. smeh). Kot navajajo Härtel in soavtorji (2015), je čustvene odzive človeškega telesa na zaznane dogodke možno relativno enostavno meriti:

- V endoktrinologiji: čustveni odziv povzroči spremembe ravni: kortisola, testosterona in oxytocina.

- V kardiologiji: čustveni odziv povzroči spremembe srčnega utripa, krvnega tlaka in spremembe $\mathrm{v}$ zapisu EKG;

- V dermatologiji: čustveni odziv povzroči spremembe električne prevodnosti kože.

Čustva imajo lahko tudi dolgoročni vpliv na zdravje. Vpliv čustev na zdravje je predmet raziskav že od leta 1970 dalje. Eno od zadnjih raziskav so opravili Ottaviani, Shapiro, Goldstein in Gofman, (2012). Z meritvami so dokazali, da čustva vplivajo na krvni tlak. Vendar so ugotovili tudi to, da vpliv čustev na krvni tlak ni pri vseh ljudeh enak. Odvisen je od osebnostnih lastnosti posameznika.

Razpoloženje je dolgoročnejše človekove stanje, ki ima podoben izvor in naravo kot čustva. Vendar je razpoloženje navzven manj izraženo, kot čustvo. Razpoloženje 
povzročijo dogodki ali dražljaji, ki so manj intenzivni. Kljub temu je razpoloženje del čustvenega sveta. (Ingram, 2015).

Že od časa Aristotela je poznano, da ima vsako komuniciranje med ljudmi dva vidika:

- prenos vsebine;

- odnos med sprejemnikom in oddajnikom ter odnos obeh do vsebine.

Odnos med sprejemnikom in oddajnikom ter odnos obeh do vsebine se odraža:

- $\quad \mathrm{v}$ vsebini komuniciranja ter

- $\quad \mathrm{v}$ pojavu čustev in razpoloženj.

Komuniciranje med ljudmi torej ni zgolj mehanistični prenos vsebine, kodirane v obliki simbolov. Ima tudi odnosno dimenzijo. Odnosni odziv v veliki meri izvira iz zaznanih simbolov. Zaznani simboli pri človeku pomenijo aktivacijo zavestnega behaviorizma (zavestnega vedenja oziroma ravnanja). Odnosna dimenzija komuniciranja se navzven manifestira tudi $\mathrm{v}$ odzivih delovanja človeškega telesa, ki so posledica zaznav (»stimulusov«) in na katere na zavedni ravni človek nima vpliva.

Preice-ova (2010) navaja naslednje faze odnosne interakcije:

- obstoj in zaznava dogodka, ki je izziv;

- percepcija izziva;

- nadaljnje mentalno procesiranje zaznanega izziva;

- biološka oziroma fiziološka reakcija človeškega telesa na izziv (npr.: sprememba frekvence srčnega utripa, rdečica na obrazu, smeh, solze, ipd.);

- vrednotenje pomena izziva na mentalni ravni;

- odločitev o reakciji ali ne-reakciji na izziv;

- zavestna odločitev o vsebini reakcije na izziv.

Pogosto se sicer nekoliko poenostavlja, da je odnosna dimenzija komuniciranja odvisna zgolj od emocij oziroma čustev. Tako razmišljanje je poenostavljeno, ker je odnosna dimenzija v resnici odvisna od več dejavnikov, tudi od dimenzij človekove osebnosti.

Človekova osebnost je predmet preučevanj že od časov Aristotela dalje. Od takrat dalje so nastale številne definicije in teorije človekove osebnosti.

Ferryal, (2012) pravi, da je človekova osebnost dinamična organizacija psiholoških in fizioloških sistemov, ki določa vsebino človekovih aktivnosti, misli in čustev. Razlike med ljudmi so posledica delovanja nevro-transmiterjev in razlik med ljudmi $\mathrm{v}$ metabolizmu možganov.

Feryal, (2012) nadalje pravi, da sta ključni dimenziji človekove osebnosti, ki določata, kakšen bo človekov odziv na zaznave temperament in značaj. 
Temperament pomeni avtomatske vedenjske reakcije človeka kot odgovor na zaznane posebne dražljaje iz okolja, kot so nevarnosti ali novosti. Glede na temperament ločimo štiri tipe temperamentnih lastnosti. Njihova poimenovanja so stara več kot 2.000 let in so: sangvinik, kolerik, flegmatik in melanholik. Temperamentne lastnosti so pri človeku relativno stabilne skozi celotno življenjsko obdobje. Feryal, (2012) se sklicuje na več rezultatov raziskav in pravi, da so temperamentne lastnosti človeka odvisne od genov.

Značaj (ali karakter) pri človeku reflektira razlike med posamezniki glede konceptov osebnih ciljev in vrednot v povezavi z izkušnjami. Vključuje razlike med ljudmi v višjih kognitivnih procesih, kot so: logično razmišljanje, sklepanje, razlaga simbolov in inovativnost. Na značaj lahko vpliva okolje (npr.: družinsko). V nasprotju s temperamentom se značaj pri človeku razvija in se spreminja skozi odraščanje, po različnih prelomnih življenjskih dogodkih, z izkušnjami in s staranjem. Dimenzije človekovega značaja so npr.:

- Stopnja samousmerjenosti izraža usposobljenosti posameznika za samostojnost, zanesljivost ipd.

- Kooperativnost se nanaša na socialne veščine, kot so podpore, sodelovanja in partnerstva.

- Samotranscendenca odraža težnjo po duhovnosti in idealizmu.

- Drugo.

Ne glede na dejstvo, da do čustev pride na nezavedni ravni in da so čustvene reakcije človeškega telesa posledica delovanja vegetativnega živčevja, pa nekatere teorije opisujejo pristope, s katerimi naj bi bilo možno upravljanje s svojimi čustvi in s čustvi drugih. Härtel in soavtorji (2015) povzemajo ugotovitve raziskav različnih pristopov:

Regulacija čustev se nanaša na zmožnost posameznika, da upravlja s svojimi zunanjimi izrazi čustev. Ti pristopi so npr.: delo $\mathrm{z}$ nasmeškom, ukrepi za zmanjšanje čustvene izčrpanosti, zunanje izkazovanje simbolov čustev skladno s pričakovanji okolja, ipd.

Čustvena inteligenca naj bi bila človekova sposobnost zaznavanja in izražanja smbolov čustev, primerjanje čustev v mislih, razumevanja in razlaganja čustev, ter urejanja čustev $\mathrm{v}$ sebi in drugih. $\mathrm{V}$ znanosti še ni natančno raziskano, kako ti mehanizmi sploh funkcionirajo. Ingram (2015) se sklicuje na več drugih raziskav in trdi, da emocionalna inteligenca ni povezana s splošno inteligenco in da se je tudi ni mogoče naučiti.

Izražanje simbolov čustev vsebuje zavedne in nezavedne, verbalne in neverbalne izraze, ki so posledica različnih čustvenih stanj. Izražanje simbolov čustev, in druge lastnosti, kot npr.: nervoze vplivajo na medosebne odnose in predvsem na zaupanje.

Okužba s čustvi pomeni, da posameznik »ujame « čustva in razpoloženja tistih, s katerimi se povezuje. Dokazano je, da se čustva in razpoloženja lahko »širijo« med posamezniki.

Človekovo čustvovanje se je skozi zgodovino nedvomno in dokazano zelo spreminjalo. Stearns in Matt (2014) se sicer strinjata, da do čustev pride na osnovi bioloških 
zakonitosti. V svoji knjigi pravita, da na čustva poleg zaznave dražljaja in človekovih notranjih dejavnikov vplivajo še drugi dejavniki. Te dejavnike imenujeta »socialnokulturni spekter«. Gre za

- regionalno kulturo;

- družbeni razred;

- versko prepričanje in pripadnost verski skupnosti;

- pripadnost subkulturi.

Razlog za spreminjanje čustev skozi različna časovna obdobja in v različnih socialnih in geografskih okoljih naj ne bi bil v spremembah mehanizma nastanka čustev pri človeku. Kot razlog za spreminjanje čustev skozi evolucijo človeka avtorja navajata "civilizacijski proces«. Ta je omejilj impulze, ki čustva povzročijo. Skozi zgodovino so se spreminjali vzroki, ki čustva povzročijo. To je imelo za posledico tudi spreminjanje manifestacije čustev. Avtorja trdita, da so prav odstopanja čustvenih reakcij posameznikov od »čustvene norme« v določenem času ali v določenem okolju povzročila družbene spremembe, ki so imele za posledico tudi spreminjaje razlogov za pojav čustev.

Avtorja tudi pravita, da so se kot posledica sprememb v družbi skozi obdobja pojavljale tudi povsem nove zaznave. Nove zaznave so pomenile nove razloge, ki so pri ljudeh povzročile tudi nova čustva. Kot primer navajata potrošništvo, kjer je vzrok za nastanek čustva zaznava pomanjkanja življenjskih užitkov.

Na podlagi fenomena spreminjanja vzrokov, ki čustva povzročijo, je v zadnjih desetletjih nastala tudi »industrija čustev«. »Industrija čustev« ljudem preko kanalov komuniciranja pošilja »simbole«, ki predstavljajo spodbude za pojav čustev. Moshe (2014) pravi, da industrija čustev generira spodbude, ki povzročajo pozitivna čustva in »čustveno dobro počutje«. Gre za produkcijo medijskih vsebin, v katerih se pojavlja in prikazuje vse, kar simbolizira uspeh: modo, potrošniške izdelke, nakit, ipd, katere ljudje zaznajo. Odziv ljudi na zaznave takih vsebin so občutki pomanjkanja. Nakup tovrstnih izdelkov pa je spodbuda za pojav čustva ugodja.

Moshe (2014) nadalje ugotavlja, da se industrija čustev ne omejuje zgolj na pozitivne čustvene dimenzije. Ravno nasprotno; častno mesto je rezervirano za manj prijetne vidike: spopadanje s tesnobo, strah, samoobtoževanja ter nezadovoljstvo, ekonomski in politični cinizem, ipd. Razlog temu je v dejstvu, da tudi za to obstajajo ciljne skupine potrošnikov in blagovne znamke, ki se lahko umestijo v tak koncept.

Moshe (2014) k industriji čustev prišteva tudi vsebine, ki se nanašajo na duhovnost in osebno rast.

\section{Behaviorizem}

Behaviorizem kot znanstvena disciplina se ukvarja s preučevanjem vplivov dejavnikov iz okolja na človekovo obnašanje. 
Obnašanje je odvisno tako od notranjih predstav posameznika, kot tudi od zunanjih vplivov. Gre za:

- notranje predstave posameznika, ki so: percepcija, kognicija, čustva, razpoloženja, spomin in razmišljanje;

- vplivi fizičnega in socialnega okolja.

Ljudje se ne moremo odločati zgolj na podlagi notranjih interpretacij, niti ne zgolj na podlagi zaznav iz zunanjega sveta. Če bi funkcionirali na tak način, bi v posameznih življenjskih situacijah lahko prišli $\mathrm{v}$ nemogoč in celo $\mathrm{v}$ življenjsko nevaren položaj. Mitkova (2014) kot primer odločanja na podlagi hkratnega vpliva notranjih in zunanjih dejavnikov navaja primer ravnanja voznika v križišču.

Kitchener in O'Donohue (1999) navajata, da so bile v 20. stoletju glavne vsebine preučevanja behaviorizma kot znanstvene discipline naslednje:

- Raziskave človekovega obnašanja $v$ borbi za golo preživetje.

- Raziskave čustvenih reakcij, predvsem negativnih. Nesporno ugotovljeno je, da je človek čustveno bitje in prav čustva imajo pomemben vpliv na človekovo obnašanje.

- Raziskave, kako korigirati obnašanje posameznikov, zlasti v smislu kliničnih implikacij.

- Raziskovanje praktičnih vprašanj-npr.: behaviorizem potrošnikov.

- Raziskovanje vplivom in medsebojne povezanosti psiholoških dejavnikov in filozofskih prepričanj na behaviorizem posameznikov.

Pennington (2000) ravnanja ljudi razvrsti v:

- spontana ravnanja, katera človek naredi, ne da bi predhodno karkoli razmišljal, in

- premišljena ravnanja.

Teorij, kaj je pravzaprav tisto, kar povzroči človekovo ravnanje, je sicer več.

V 20. stoletju je bila najbolj uveljavljena teorija S-R (stimulus-response) (Kitchener in O'Donohue, 1999)

Behaviorizem je po teoriji S-R človekov odgovor na dražljaje iz okolja v obliki refleksov in ravnanj. Refleksi in ravnanja so posledica zaznanih dražljajev, vplivov človekovih genov, preteklih izkušenj, zdravstvenega stanja, motivacije in drugih dejavnikov. 
Liu in soavtorji (2007) navajajo in tudi dokazujejo, da gre pri človekovem odzivu pravzaprav za delovanje dveh med seboj ločenih sistemov, ki pa sta $\mathrm{v}$ medsebojni interakciji:

- »Trebušni« sistem človeku omogoča zavestno identifikacijo nečesa (npr.: vid, ki nam omogoča prepoznavo skodelice).

- »Hrbtni« sistem človeku omogoča podzavesten odziv (npr.: sistem, ki omogoča z roko doseči skodelico).

Liu in soavtorji (2007) so dokazali, da je zavestna identifikacija potrebna za to, da nek odziv v možganih "planiramo«. Do odziva pa lahko pride tudi, če se zavestna identifikacijo nečesa prekine. Po skodelici namreč lahko sežemo tudi v temi, ko ugasnemo luč.

Da sta sistema med seboj ločena dokazuje dejstvo, da ni nujno, da kar avtomatsko sežemo po skodelici vsakič ali takoj, ko jo vidimo. Sistem, ki omogoča zavestno identifikacijo, je znanost relativno dobro raziskala, sistema, ki omogoča podzavesten odziv pa ne.

Do določene mere je človekove mehanizme odzivanja na zaznave pojasnila Mitkova (2014), ki potrjuje, da je za nastanek ravnanja potreben »stimulus«, oziroma zaznava. Ali bo do odziva na zaznavo sploh prišlo oziroma kakšen bo način človekovega ravnanja, pa je odvisno od konteksta.

Mitkova (2014) navaja zunanji kontekst in notranji kontekst.

- Zunanji kontekst pomeni zaznavo in je zaznano fizično okolje, (torej percepcija) ki »aktivira « elemente notranjega konteksta.

- Notranji kontekst referira, kognicijo (že prej obstoječa spoznanja o zaznanem), izkušnje posameznika, kot tudi vse ostale elemente mentalne kronologije dogodkov. V skladu s tem pogledom so čustveno stanje, razpoloženje, ipd štejejo kot notranji kontekst.

Pennington (2000) se sklicuje na starejše raziskave in dejavnike, na podlagi katerih se ljudje odločamo. Razvrsti jih v:

- dispozicijske dejavnike, ki izhajajo iz samega človeka (temperament, značaj) in

- situacijske dejavnike, ki jih človek sprejme iz okolja v obliki zaznav.

Stopnja vpliva dispozicijskih in situacijskih dejavnikov je od človeka do človeka različna in se razlikuje celo med rasami. Pennington (2000) navaja primer raziskave dejavnikov, ki pripeljejo do storitve umora in ugotavlja, da $\mathrm{v}$ ameriški populaciji prevladujejo dispozicijski dejavniki, v kitajski populaciji pa situacijski dejavniki. 
V notranjih in zunanjih kontekstih, kot jih opisuje Mitkova (2014), nastopajo trije elementi:

- Element razloga oziroma obrazložitve se nanaša na zaznavo, ki je sprožilni mehanizme sklepanja.

- Element ozadja in okoliščin se nanaša na to, $v$ kolikšni meri so elementi okoliščin in ozadja zaznave že zastopane v človekovem spominu.

- Element spomina preverja nazadnje aktivirano informacijo.

Dokazano je, da na ravnaje lahko vplivajo tudi drugi nebistvene elementi kontekstov. Mitkova (2014) opisuje, kako nebistveni elementi zaznave objekta (npr. barve) vplivajo na proces ocenjevanja velikosti objekta. Nadalje kot primer opisuje, kako zunanji kontekst zaznave vpliva tudi na pripravljenost človeka, da tvega. Z eksperimenti je bilo dokazano, da so bili ljudje bolj pripravljeni s kartami igrati za denar v primeru, ko so na hrbtni strani kart fotografije ljubkih otrok, kot v primeru, ko so karte nevtralnih barv. Navaja tudi primer oglaševanja tveganih investicijskih skladov, kjer so v ozadju slike mesta.

Treba je poudariti, da teorija S-R ne daje vseh odgovorov na vprašanja $\mathrm{V}$ zvezi z behaviorizmom. Zlasti ne odgovori na vprašanji:

- Kakšen je mehanizem »odpravljanja napak« oziroma »netočnosti« pri odzivu v primeru prekinitve zaznave? (Npr.: kakšen je mehanizem korekcije, če v temi sežemo po skodelici).

- Zakaj se pri človeku ravnanja pojavijo tudi, če ni dražljajev iz okolja?

\section{Podatek, sporočilo, informacija}

Zaznave za človeka lahko predstavljajo »podatek«, »sporočilo« ali »informacijo«.

Podatek obstaja, kadar so znaki oziroma simboli razvrščeni v sintaktično celoto (npr.: črke v besedi). Sporočilo je podatek, kateremu prejemnik pripiše nek pomen. (Podbregar in soavtorji, 2010)

Informacija prinaša nekaj, česar pred njenim sprejemom še nismo vedeli. Izzove začetek dejavnosti posameznika ali organizacije kot celote. Bistvena razlika podatka in sporočila od informacije je $\mathrm{v}$ tem, da informacija pri sprejemniku izzove neko aktivnost. Če zaznava ne izzove akcije, potem to ni informacija, temveč samo podatek ali sporočilo.

Informacije so podatki, obvestila in opisi v verbalni, numerični ali slikovni obliki o stanju sistema, oziroma o poteku procesa, v preteklosti, sedanjosti in prihodnosti. Informacije so potrebne za odločanje. Osnovne lastnosti informacije so:

- Pripoveduje nekaj, česar doslej še nismo vedeli.

- Povečuje znanje.

- Zmanjšuje negotovost (čeprav obstajajo tudi primeri, ko (tudi popolna) informacija povečuje negotovost). 
Teoretične osnove komuniciranja: Sprejemnik

- Pomaga pri predstavah o bodočem stanju sistema ali okolja.

- Vpliva na obnašanje posameznikov in organizacije kot celote.

- Lahko spremeni verjetnost, da se bodo določeni dogodki dejansko zgodili.

- Izzove določene odločitve. (Vila, 1994). 
PoSLOVNO KOMUNICIRANJE

M. Ferjan 

Ljudje že od prazgodovine dalje živimo v skupnostih. Človek je že po svoji naravi bitje, ki v naravi zelo težko preživi sam. Delo si med seboj delilmo Z razvojem civilizacije in napredkom tehnologije je delitev dela postajala vedno bolj izrazita. Kaj kmalu je poleg delitve dela prišlo tudi do razdelitve vlog v družbi. Z razvojem industrijske proizvodnje je postala potreba po delitvi dela še večja. Zato so organizacije razvile poslovne funkcije. Hkrati se je povečevalo tudi število interakcij organizacij z okoljem in med ljudmi nasploh.

$\mathrm{V}$ tej knjigi obravnavamo vprašanja razvoja poslovnih funkcij organizacije $\mathbf{v}$ odvisnosti od interakcij organizacije z okoljem:

- Kako so se pri ljudeh razvijale socialne sheme v odnosu do organizacij?

- Katere so za organizacijo ključne vsebine interakcij z okoljem?

- Kaj je tisto v zvezi z organizacijo, na kar se v določenih stopnjah razvoja najbolj osredotoča kolektivna kognicija dejavnikov okolja?

- Od katerih atributov organizacije $\mathrm{v}$ povezavi z dinamiko razvoja socialnih shem v okolju je odvisen behaviorizem ljudi v odnosu do organizacije?

- Katera poslovna funkcija je tista, ki ji v spreminjajočem se okolju organizacija namenja prevladujoč pomen?

Da bi se organizacije prilagodile okolju, so se stalno prilagajala. Božidar Novak (1999) je opredelil pet tipov podjetij:

- proizvodno podjetje;

- prodajno podjetje;

- trženjsko (marketinško) naravnano podjetje;

- družbeno koristno podjetje;

- percepcijsko podjetje.

Pri opredelitvi tipa podjetja gre za vprašanje, kateri usmeritvi oziroma kateri poslovni funkciji podjetje namenja prevladujoč pomen, pri čemer praviloma ostalih usmeritev ne opušča. Tudi, če govorimo o prodajnem podjetju, produkt nekdo proizvesti. Kot pravi Novak (1999), noben od tipov podjetij ne obstaja in ne more obstajati v čisti obliki. 
Stopnje razvoja organizacij 


\section{PROIZVODNA ORGANIZACIJA}

Proizvodna organizacija je primarno usmerjena v proizvodnjo dobrin. Proizvodnja ima večtisočletno zgodovino. Bila je nujna za preživetje človeštva. Poleg varnosti je bil ključni problem zagotavljanje hrane. Človek se je v davnini sprva ukvarjal z nabiranjem plodov narave in $\mathrm{z}$ lovom. V jamah, ki so jih v davnini ljudje uporabljali za bivališča, so bile najdene slike lova, ki so stare vsaj 15.000 let. Za lov, kasneje pa še za kmetijstvo, si je človek moral poiskati, kasneje pa tudi sam izdelati izdelati pripomočke. Pred več kot 5.000 leti se je naučil pridobivati materiale iz narave-npr. baker, kasneje pa tudi druge kovine. Od takrat dalje je razvoj pridobivanja materialov šel pot, ki jo vsi poznamo. Vzporedno je človek razvijal tudi postopke preoblikovanja materialov v uporabne izdelke. Organizirana masovna proizvodnja se je pojavila že v starem veku. Rimljani so tako npr. že obvladali organizirano masovno proizvodnjo steklovine. Skozi zgodovino je človeštvo postopke proizvodnje dobrin stalno izboljševalo. Izboljšave $\mathrm{V}$ zvezi $\mathrm{S}$ tehnologijo in materiali so se nanašale na:

- iskanje in pridobivanje materialov,

- preoblikovanje materialov v izdelke;

- spajanje istovrstnih in kasneje različnih vrst materialov;

- izdelavo posameznih komponent in povezovanjem v delujoče sisteme;

- povezovanje različnih sistemov v delujoče kompleksne sisteme;

- obstojnost materialov in izdelkov,

- logistiko.

Razvoj tehnoloških postopkov je pomenil tudi večjo zahtevnost dela. Stopnje zahtevnosti dela v odvisnosti od tehnološkega razvoja je že leta 1976 opredelila Polićeva (1976):

1. enostavno ročno delo,

2. ročno delo $\mathrm{z}$ ročnim orodjem,

3. delo z univerzalnimi stroji,

4. delo z polavtomatski stroji,

5. delo na mehaniziranem tekočem traku,

6. avtomatski stroj, avtomatski tekoči trak,

7. avtomatska naprava $\mathrm{s}$ samostojnim merjenjem operativnih pogojev in rezultatov procesa,

8. avtomatska naprava, ki je opremljena s samostojno regulacijo,

9. avtomatska naprava, ki je poleg tega opremljena še $\mathrm{z}$ avtomatsko evidenco karakterističnih parametrov proizvodnega procesa,

10. avtomatska naprava, ki se avtomatično prilagaja pogojem in samostojno opravi izbor najučinkovitejše metode,

11. avtomatske naprave, ki sodelujejo pri tehničnih in ekonomskih vidikih proizvodnega procesa. 
Tisočletja se je večina ljudi ukvarjala s pridobivanjem hrane, to je sprva z lovom, kasneje pa s kmetijstvom. Za prvo industrijsko revolucijo se šteje prehod iz ročne $\mathrm{v}$ strojno proizvodnjo na prelomu iz 18. v 19. stoletje. Po nekaterih podatkih (Gallman, Weiss, 1969) se je še leta 1840 v ZDA 70\% od vseh zaposlenih ljudi ukvarjalo s kmetijstvom, ustvarili pa so približno $50 \%$ BDP. V industriji je bilo zaposlenih zgolj približno $10 \%$ ljudi in so ustvarili približno $20 \%$ BDP.

Pomembni mejniki v razvoju proizvodnje so bili: odkritje parnega stroja, odkritje elektrike in zlasti odkritje motorja z notranjim izgorevanjem. Obdobje po odkritju motorja z notranjim izgorevanjem od leta 1920 do leta 1970 imenujemo industrijska družba. Po nekaterih podatkih (Gallman, Weiss, 1969) se je v ZDA:

- leta 1910 v ZDA samo še 35\% od vseh zaposlenih ukvarjalo s kmetijstvom, ustvarili pa so samo še približno $15 \%$ BDP,

- v industriji pa je bilo leta 1910 zaposlenih že približno 30\% ljudi in so ustvarili več kot $40 \%$ BDP.

Vzporedno z razvojem industrije se je pojavila potreba po storitvah. V storitvah je bilo leta 1910 v ZDA zaposlenih že približno $35 \%$ ljudi.

Podobna situacija je bila drugje na ozemlju današnjih držav G7. Kot primer navajamo Nemčijo (upoštevajoč ozemeljske spremembe po letu 1945), kjer je bilo:

- leta $1925 \mathrm{v}$ rudarstvu zaposlenih 43,6\% delovno aktivne populacije, $\mathrm{v}$ industriji pa $29,7 \%$;

- leta $1970 \mathrm{v}$ rudarstvu zaposlenih 8,7\% delovno aktivne populacije, $\mathrm{v}$ industriji pa 39,3\%. (Castells, Aoyama, 1994).

Tehnološke spremembe so povzročile tudi družbene spremembe. Število delovnih mest z ponavljajočimi se operacijami se je zmanjševalo. Vzporedno s tehnološkim napredkom se je razvijala tudi organizacija. Glavna značilnost sprememb organizacij je predvsem ta, da se je povečevalo število interakcij med ljudmi. Povečala se je tudi potreba po hitri odzivnosti posameznikov in sistemov kot celot.

S pojavom polprevodniške tehnologije, še posebej z odkritjem mikroprocesorja leta 1971, je spet prišlo do sprememb. Začelo se je govoriti o postindustrijski družbi. Tudi ta tehnološka sprememba je povzročila velike spremembe v strukturi družbe. Leta 1987 je bilo v Nemčiji v industriji zaposlenih le še 29,58 delovno aktivne populacije. (Castells, Aoyama, 1994).

V tisočletjih razvoja se je torej proizvodnja dobrin zelo spremenila. Vendar v človeški zgodovini brez proizvodnje dobrin seveda ni šlo, ne gre in tudi v prihodnje ne bo šlo. Danes v Evropi govorimo o pojmu »Industrija 4.0«. Gre za trend avtomatizacije proizvodnje in načina izmenjave podatkov. Pojem »Industrija 4.0 je predstavila nemška vlada na sejmu v Hanovru leta 2011. 
"Industrija 4.0" je tekoči projekt, ki so ga sprožile naslednje spremembe:

- potreba po skrajševanju časa razvoja novih produktov;

- individualizacija na strani povpraševanja;

- potreba po prilagodljivosti proizvodnje;

- decentralizacija;

- zagotavljanje trajnostne učinkovitosti ekonomskih in okoljskih virov. (Lasi et. al. 2012).

Kljub temu:

- da so se v proizvodnji uporabljali vedno novi in novi materiali,

- da je tehnologija napredovala;

- da se je produktivnost v proizvodnji povečala in

- da so organizacijske strukture postajale vedno bolj kompleksne,

se je doprinos proizvodnje dobrin v svetovni BDP zmanjševal. Po podatkih Svetovne banke je še leta 1995 proizvodnja dobrin prispevala 21,24\% svetovnega BDP, leta 2014 pa samo še $14,89 \%$. Seveda se stanje med državami razlikuje: proizvodnja dobrin je leta 2014 v Sloveniji prispevala 23,05\% BDP, v Nemčiji 22,97\%, v Luksemburgu samo $5,70 \%$, v Južni Koreji 30,15\% (za Kitajsko ni podatka). ${ }^{10}$ Po podatkih McKinsey Global Institute iz leta 2012, je na svetu povprečno za vsak ustvarjen dolar v proizvodnji potrebnih za 19 dolarjev vhodnih storitev (Manyikla, J. et. al., 2012). Storitve so po podatkih EUROSTAT tako v državah EU-28 v letu 2015 prispevale 73,9\% BDP, primerjalno z $71,9 \%$ v letu $2005 .^{11}$

${ }^{10}$ vir: The World Bank national accounts data, http://data.worldbank.org/indicator/NV.IND.MANF.ZS? end $=2014 \&$ start $=1995 \&$ view $=$ map

${ }^{11}$ Vir: http://ec.europa.eu/eurostat/statistics-.. 
Stopnje razvoja organizacij 


\section{PRODAJNA ORGANIZACIJA}

Prodajno podjetje je primarno usmerjeno v prodajo. Obstaja prepričanje, da se je prodaja dobrin pojavila takrat, ko so ljudje kot posamezniki ali celice človeške družbe ustvarili več dobrin nekega tipa, kot so jih porabili. Brez, da bi neko dobrino, pa naj si bo to izdelek ali storitev proizvedli, prodaja seveda ni možna. Zgodovinarji in arheologi si niso enotni, kje in kdaj se je prodaja pojavila. Precej verjetna je domneva, da se je menjava dobrin pojavila v času razvoja poljedelstva. Obstaja soglasje, da se je organizirana prodaja dobrin pojavila na tržnicah v prvih mestih. V Evropi naj bi bila to mesta starih Keltov in starih Grkov. Nekateri viri celo navajajo, da obstajajo arheološki dokazi o obstoju tržnice že pred več kot 10.000 leti. Tržnica v klasični obliki ali v obliki sodobnega nakupovalnega centra še dandanes ostaja eden od načinov prodajanja dobrin.

Mednarodna trgovina naj bi se pojavila v pozni bronasti dobi. Findlay in soavtorji (2006) se sklicujejo na podmorske arheološke najdbe v vzhodnem delu Sredozemskega morja. Domnevajo, da je takrat že obstajala trgovska pot od vzhodnega Sredozemlja do obal današnjega Egipta. Findlay in soavtorji (2006) nadalje opisujejo podmorske arheološke najdbe Feničanskih trgovskih ladij iz 13. stoletja pred našim štetjem, ki naj bi bile 14 metrov dolge in 6 metrov široke. Ladje in amfore na njih naj bi imele izvor na ozemlju današnjega Libanona. Distribucija dobrin po morju je bila očino dovolj poceni. To obdobje se je na nek način zaključilo s propadom vzhodnega rimskega cesarstva. Razlogi za to so bili predvsem $\mathrm{v}$ vojnah na tem območju, ki so sčasoma povzročile tudi redistribucijo vojaške in politične moči in spremembe meja političnih entitet.

Za obdobje od konca antike do konca 15. stoletja je malo dokazov o stalni rasti ravni dohodka in s tem o razvoju trgovine. Teorije o razlogih za to so različne. Nekateri si to razlagajo z demografskimi gibanji. Gre za problem nesorazmerja med rastjo človeške populacije in zmožnostmi za proizvodnjo hrane. Po drugih teorijah (npr.: Wallerstein, 2011) pa je bila ovira v tem, da je bila fevdalna Evropa sestavljena iz množice majhnih političnih entitet. Meje med velikim številom majhnih držav so za trgovanje predstavljale oviro. Mnoge od srednjeveških držav (npr.: na ozemlju današnje Italije ali Nemčije) so bile sicer vključene v medsebojno trgovanje. Vendar pa niso bila del nekega večjega gospodarskega sistema. Poleg tega so si bile države pogosto v vojnah. Zaradi tako razdrobljene politične ureditve so bili tudi veliki problemi v logistiki, ki je ključna za razvoj trgovine.

Wallerstein (2011) postavlja vprašanje, če je mogoče trditi, da konec 15. stoletja vsaj v nekaterih delih Evrope že lahko štejemo za začetek kapitalizma. Takrat je namreč prišlo do pomembnega premika; leta 1492 je Krištof Kolumb odkril Ameriko. Težišče trgovine se je iz Sredozemlja preselilo v severozahodno Evropo: na Nizozemsko, v Anglijo in v Francijo. Začela se je konsolidacija nekaterih politični entitet v Evropi in kolonizacija sveta. Evropske države so kolonizirale številna območja preostalega sveta. Začele so s politiko ekonomskega nacionalizma in hegemonizma. Obdobje od 1600 do 1750 
zgodovina šteje za obdobje merkantilizma. Merkantilizem je oblika gospodarskega nacionalizma. Gre za to, da neka država obdrži čim več prevlade svojih gospodarskih aktivnosti na nekem geografsko zaokroženem območju, naj si bo to na ozemlju države ali na ozemlju svojih kolonij. Z različnimi instrumenti država drugim zapira možnost vstopa na trge, ki jih je osvojila. Merkantilizem je torej obdobje, ko so nekatere države izvajale vojaške, politične in ekonomske ukrepe, da so poslovno in finančno prevladovale nad drugimi. Findlay (2006) meni, da je verjeten razlog za merkantilizem v prepričanju korporacij in politike, da je velikost trga fiksna, torej da se potencial trga ne povečuje. Poleg tega je stoletja veljalo, da državne meje za trgovanje predstavljajo oviro.

Wallerstein (2011) za začetnico merkantilizma šteje Nizozemsko. Nizozemska je svojo prevlado dosegla s tem, da so se po letu 1400 tam pojavili presežki hrane, po drugi strani pa so izumili ladje, ki so bile hitrejše, bolj okretne in bolj varne kot dotedanje ladje. Takratni Anglija in Francija sta bili preobremenjen s svojimi notranjimi problemi. Nizozemska hegemonija je bila prvič resno ogrožena šele po letu 1651.

Brinley (1993) navaja, da so postale angleške ladje v obdobju od 1649 do 1859 kar enajstkrat večje, kot v obdobju 1558 do 1603 . S tem je prišlo do angleške prevlade na morju. Obdobje od 1700 do 1776 imenuje obdobje Atlantske ekonomije.

Nekateri avtorji (npr.: Brinley, 1993) menijo, da je bila industrijska revolucija v Angliji spodbujena prav z borbo in zmago Anglije za prevlado na morju. Prevlada na morju je namreč povečala obseg trgovine Anglije in s tem povečala potrebo po novih produktih. Vse to je povzročilo tudi demografske posledice. Śtevilo prebivalcev Anglije je naraslo od približno 5 milijonov okoli leta 1650 na približno 15 milijonov okoli leta 1850 . S tem se je seveda povečal tudi potencial notranjega trga.

Prodajna funkcija je torej ena od poslovnih funkcij podjetja in družbe kot celote. Trgovina je povzročila vzpon držav in civilizacij. Kot ugotavljata Moncrief in Marshall (2005) se koraki klasične prodaje $\mathrm{v}$ zadnjem stoletju praktično niso spremenili in ostajajo naslednji:

1. Raziskovanje ciljne skupine: poiskati tistega, ki mu bo proizvod prinesel neko dodano vrednost, ki ga bo kupil in tudi plačal.

2. Vzpostavitev zaupanja: zaradi ogromne ponudbe na trgu in morda preteklih slabih izkušenj so ljudje nezaupljivi, zato je treba pridobiti zaupanje potencialnih kupcev.

3. Postavljanje vprašanj: potencialnim kupcem je treba postavljati vprašanja, in šele na osnovi odgovorov se ugotovi, ali je sploh smiselno nadaljevati $\mathrm{s}$ procesom prodaje.

4. Predstavitev produkta: proizvod je na preprost in hitro razumljiv način treba predstaviti kupcu.

5. Odprava dvomov: odgovore na morebitne dvome je treba pripraviti vnaprej. Dvomi kažejo na obstoj interesa po nakupu.

6. Sklenitev posla.

7. Postprodajne aktivnosti: ohraniti je treba kontakt s kupcem. 
Bistvo klasičnega prodajnega koncepta je zgolj to, da pride do menjave - to je do prodaje izdelka ali storitve. 
Stopnje razvoja organizacij 


\section{TRŽENJSKA (MARKETINŠKA) ORGANIZACIJA}

Trženjsko (marketinško) podjetje je za razliko od klasičnega prodajnega koncepta izrazito usmerjeno k zadovoljitvi potreb uporabnikov.

Kot pravi Devetak (1999) se je leta 1973 pri nas namesto pojma marketing začel uporabljati pojem trženje. Oba pojma pa po njegovem pomenita eno in isto

Med prodajno organizacijo in marketinško organizacijo obstaja velika konceptulana razlika. Res je sicer, da mnogi marketing še danes dojemajo in tudi prakticirajo zgolj kot način prodajanja izdelka. Prodaja in poslovni izid sta brez vsakega dvoma zelo pomembni. Toda pravo bistvo marketinga je v zadovoljitvi potrebe kupca.

Philip Kotler je postavil definicijo, da je marketing transakcija ali menjava vrednosti, med dvema strankama znotraj socialne skupnosti. Pri tem vrednosti ne predstavlja samo denar, izdelek ali storitev, pač pa tudi porabljen čas, vložena energija in občutki. (Kotler, 1989). Osnovni proces marketinga je menjava. Da lahko pride do menjave, je treba zadovoljiti petim pogojem:

1. Obstajati morat interes dveh strani za menjavo.

2. Vsaka stran mora imeti nekaj, kar naj bi imelo vrednost za drugo stran.

3. Vsaka od strani mora biti sposobna komunicirati in izročiti.

4. Vsaka od strani lahko svobodno sprejme ali zavrne ponudbo.

5. Vsaka stran mora biti prepričana, da je dobro in celo zaželeno, da se dogovarja z drugo stranjo (Kotler, 1996).

Po zaključku procesa menjave morata biti zadovoljni obe strani:

- kupec mora biti zadovoljen $\mathbf{z}$ nakupom;

- prodajalec mora imeti pozitiven denarni tok in pozitiven poslovni izid.

Nekateri avtorji (Usui, 2008): navajajo tristopenjski evolucijski model razvoja marketinga:

- Obdobje produkcije in produktov: organizacije so usmerjene v proizvodnjo velikih količin kakovostnih in uporabnih dobrin ob nizkih proizvodnih stroških ter po sprejemljivi prodajni ceni.

- Obdobje prodajanja: organizacije so usmerjene v agresivno oglaševanje in promocijo ter prodajo.

- Obdobje marketinga: organizacije so dejansko osredotočene na potrebe in želje potrošnikov.

Ključno bistvo marketinškega koncepta je teoretično pojasnil in utemeljil šele Wroe Alderson leta 1957. Po njegovem je bistvo marketinškega koncepta v tem, da se zagotovi 
zadovoljstvo potrošnika. Zadovoljstvo potrošnika se ne zagotovi zgolj z izdelkom ali storitvijo, pač pa tudi na druge načine. Teoretiki in praktiki ${ }^{12}$ torej postavljajo ključno razliko med klasičnim prodajnim konceptom in filozofijo marketinškega koncepta $\mathrm{v}$ tem, da je prodajno orientirano podjetje naravnano izključno na produkt oziroma na to, kako produkt prodati. Marketinški koncept pa je usmerjen $\mathbf{k}$ zadovoljitvi potreb uporabnika in zato vsebuje tudi druge elemente. V začetku so bili ti elementi zlasti naslednji:

- lastnosti samega produkta $\mathrm{v}$ smislu uporabnosti, kakovosti in izpolnitve drugih pričakovanj;

- cena in način plačila;

- prodajni kanal oziroma način prodaje;

- dostava.

V zgodovini marketinga so se razvili modeli merjenja zadovoljstva strank. Eden prvih in še danes najbolj poznanih modelov merjenja zadovoljstva strank je model J. D. Power. Leta 1968 ga je razvil Dave Power. Prvotno je bil namenjen merjenju zadovoljstva kupcev avtomobilov.

Leta 1989 se je na Švedskem začel uporabljati barometer zadovoljtva strank (Swedish Customer Satisfaction Barometer - SCSB).

Ameriški indeks zadovoljstva sztrank (The American Customer Satisfaction Index $A C S I)$ temelji na ocenah strank o kakovosti blaga in storitev, kupljenih v Združenih državah Amerike. Uporabljati se je začel leta 1994.

Opravljene so bile številne znanstvene in komercialne raziskave, ki kažejo, da med zadovoljstvom strank in verjetnostjo ponovega nakupa pri istem ponudniku obstaja pozitivna korelacija.

Mnogi avtorji menijo, da koncept marketinga izhaja iz ekonomske doktrine liberalizma, katere začetniki so živeli že v 18. stoletju, to je v času začetkov industrijske revolucije. Doktrina liberalizma se je razvila $v$ razsvetljenstvu. Pomeni nasprotje merkantilizmu in takrat ponekod še obstoječemu fevdalizmu. Za začetnika doktrine liberalizma se šteje Adam Smith (1723-1790).

Bistvo ekonomske doktrine liberalnega tržnega gospodarstva je v svobodi odločitve posameznika v okviru zakonov, pri čemer si vsak posameznik prizadeva izboljšati svoj položaj, seveda v okviru zakonov. Koncept marketinga v 18. stoletju ni mogel zaživeti, ker takrat še niso bili izpolnjeni potrebni pogoji:

- Proizvodnja dobrin še ni bila razvita do te mere, da bi na trgu sploh obstajala možnost zelo velike izbire.

- Kupna moč ljudi je bila še premajhna.

${ }^{12}$ Glej tudi npr.: Homburg, Jensen, 2007 
Poslovno KOMUNiCIRANJe 69 Stopnje razvoja organizacij: Trženjska (marketinška) organizacija

- Infrastruktura za masovno distribucijo dobrin še ni bila razvita do zadostne mere.

Marketing ni le ekonomska kategorija, pač pa ima širše družbene razsežnosti. Bartels (1976) pri opisu razvoja marketinga navaja, da družbene vrednote postanejo vedno bolj pomembne tudi za marketing, vendar ne v smislu vpliva družbe na marketing, pač pa obratno, torej v smislu vpliva marketinga na družbo.

Filozofijo marketinga bomo na kratko razložili s kratkim prikazom njegove zgodovine. S prikazom zgodovine lahko pojasnimo bistvo obstoja marketinga kot ekonomske in družbene kategorije. Pripomore tudi k temu, da razumemo bistvo sedanjosti, to je bistvo digitalnega marketinga.

Zgodovinski razvoj koncepta marketinga so opisali številni avtorji. Opisujejo različne vidike:

- razvoj pristopov k praksi marketinga;

- razvoj izobraževanja o marketingu;

- kronološki pregled literature, strokovnih dogodkov, nastanka strokovnih združenj in nenazadnje znanosti o marketingu.

Pri pregledu zgodovine je pomemben vpogled $\mathrm{v}$ vsebino in $\mathrm{v}$ sam razvoj koncepta marketinga. Manj pomembna pa je natančno opredelitev časovnih obdobij. Časovna obdobja o tem, kdaj so se določeni pristopi pojavili, je pri branju literature tega področja nasploh treba jemati precej z rezervo. Treba jih razumeti zgolj kot približni časovni okvir, torej orientacijsko. Različni avtorji literature postavljajo različne trditve o tem, kdaj naj bi se nekateri pristopi pojavili.

- Bartels (1976) trdi, da je koncept dobil ime med leti 1900 in 1910, Usui, (2008) pa pravi, da se je beseda marketing pojavljala že v slovarjih angleškega jezika v ZDA leta 1832 in 1856 ter v Angliji leta 1932.

- Wikipedia in viri, na katere se le-ta sklicuje navajajo, da je bil zelo znan in razširjen koncept 4P (angl.: product-price-place-promotion oziroma slovensko: produkt-cena prodaja-promocija) prvič predstavil avtor Edmund Jerome McCarthy leta $1960 \mathrm{v}$ knjigi Basic Marketing: A Managerial Approach. Nekateri avtorji (npr.: Usui, K., 2008) pa navajajo, da naj bi se koncept 4P pojavil že takoj po 2 . svetovni vojni.

Največ pregledov zgodovine marketinga je nastalo v ZDA, zato jih po svetu najpogosteje omenjajo. ZDA se štejejo tudi za domovino marketinga. Vendar ameriški pogled na zgodovino marketinga doživlja tudi številne kritike. Dejstvo je namreč, da je razvoj marketinga v številnih državah (v Angliji, Nemčiji, Avstraliji, Kanadi in na Japonskem) šel svojo pot in je bil morda drugačen, kot v ZDA.

Velja pa splošno prepričanje, da se je marketinški koncept pojavil na prelomu iz 19. v 20. stoletje. Podobno, kot se je tržnica kot organizirana oblika prodaje lahko pojavila šele z 
razvojem naselij, se je marketing lahko razvil šele, ko je bila zgrajena potrebna infrastruktura. Za pojav marketinga je ključno naslednje:

- Industrializacija je povzročila selitev ljudi $\mathrm{v}$ mesta ter $\mathrm{s}$ tem večjo koncentracijo prebivalstva $\mathrm{z}$ bolj ali manj stalnim virom dohodkov.

- Izgradnja mreže železnic $\mathrm{v}$ ZDA in Evropi je omogočila boljše možnosti dostave.

- Razvoj finančnih institucij je omogočil masovno kreditiranje nakupov.

- Z razvojem množičnih medijev (najprej tiska, kasneje pa še kina, radija in televizije) se je lahko pojavilo oglaševanje.

Kot ugotavlja Palumbova (2014) je v ZDA leta 1906 prišlo tudi do poenotenja zakonodaje na področju trgovanja med posameznimi državami.

Usui (2008) navaja, da sta bila ključni faktorja za nastanek marketinga tudi kapitalistični družbeni red in obstoj managementa v podjetjih. Navaja tudi, da se je marketing pojavil po industrijski revoluciji z določenim časovnim zamikom, kar najbrž kaže na to, da so v začetni fazi industrializacije podjetja ključno pozornost namenjala proizvodni funkciji. Z vidika managementa lahko marketing razumemo tudi kot odziv managementa na potrebe in želje potrošnikov.

Baker in Saren (2016) sicer navajata številne primere uporabe principov marketinga že prej, npr. segmentacijo trga knjig v Nemčiji v 19. stoletju. Dejstvo je, da so ti primeri nedvomno obstajali, vendar najbrž ni šlo za sistematičen in razširjen koncept.

Praksa modernega marketinga se je začela s tem, ko si je potrošnik izdelke pred nakupom lahko ogledoval v oglasih ali katalogih, ko je za nakup dobil kredit in ko so mu po nakupu izdelek lahko dostavili na dom.

Bartels (1976) je začetno obdobje razvoja marketinga v ZDA opisal takole:

- 1900-1910: Obdobje odkritja. V tem obdobju se je v ZDA pojavil koncept trženja oziroma marketinga. Pojavilo se je kreditiranje nakupov, distribucija izdelkov in promocija. Koncept je po njegovem takrat dobil ime. ${ }^{13}$

- 1910-1920: Obdobje konceptualizacije. Leta 1915 je bilo v ZDA ustanovljeno Združenje učiteljev marketinga. Razviti so bili številni začetni koncepti. Izišle so prve knjige s področja marketinga.

- 1920-1930: Obdobje integracije. V tem obdobju so bili objavljeni številni strokovni članki, organizirana so bila prva srečanja teoretikov in praktikov. Leta 1925 je bilo ustanovljeno prvo združenje akademikov, ki se je kasneje preoblikovalo v AMA (American Marketing Assotiation).

Kot navaja Weitz (2002) so v Angliji na univerzah marketing začeli poučevati eno leto prej kot v ZDA (leta 1901 v Birminghamu). Bartels (1976) pa navaja, da so o konceptu marketinga leta 1902 začeli poučevati tudi na univerzah v ZDA. Kot navaja Weitz (2002)

${ }^{13}$ Kot smo omenili, nekateri drugi viri trdijo, da se je ime pojavljalo že prej. 
se za prvi učbenik šteje knjiga Marketing Methods and Policies, ki je izšla leta 1917 v ZDA. Leta 1947 je izšla prva retrospektiva o marketingu. V obdobju od 1936 do 1947 je bilo samo v ZDA objavljenih kar 435 znanstvenih ali strokovnih člankov o marketingu. (Weitz (2002)

Koncept marketinškega spleta je eden od najpomembnejših konceptov marketinga. Koncept marketinškega spleta je tako po vsebini kot časovno sovpadal z ekonomsko doktrino neoliberalizma. Bistvo doktrine neoliberalizma je deregulacija trgov, prosta trgovina, določanje cen na trgu idr. Eden najvidnejši zagovornikov neoliberalizma je bil ameriški ekonomist Milton Friedman (živel od 1912 do 2006). Friedman je bil ameriški ekonomist, ki je leta 1976 prejel tudi Nobelovo nagrado za ekonomske znanosti.

Koncept marketinškega spleta je v bistvenih elementih skladen $\mathrm{z}$ ekonomsko doktrino neoliberalizma. Ključna razlika je zgolj v idealiziranem pojmovanju namena obstoja podjetja. Po neoliberalni ekonomski doktrini je namen poslovanja podjetja ustvarjati dobiček, bistvo marketinga pa je zadovoljiti potrebe, želje in pričakovanja kupca. To dvoje se med seboj ne izključuje.

Kot navaja Chai Lee Goi (2009), naj bi se koncepti, podobni danes pogosto citiranim novejšim konceptom marketinškega spleta pojavili že pred 2. svetovno vojno. Omenja teorijo marketinga, ki se je pojavila po letu 1930 in vsebuje naslednje štiri elemente: cena, kakovost, storitev in oglaševanje. Kot pravi Chai Lee Goi (2009), naj bi ta teorija imela svoj prvotni izvor v črki »P«(ki pomeni »price« oziroma ceno). Gre torej za prvi zametek kasnejše teorije 4P. V začetnih obdobjih marketinga je nasploh veljalo, da je cena sploh edini element marketinga.

Fraza »marketinški splet« (»marketing mix«) naj bi se (spet) začela uporabljati po 2. svetovni vojni. Prvi naj bi jo (spet) uporabil Neil Borden leta 1949. Marketinški splet po Borden-u je imel 12 elementov:

1. planiranje produkta;

2. cena;

3. »brandiranje «;

4. kanal distribucije;

5. osebna prodaja;

6. oglaševanje;

7. embalaža;

8. predstavitve:

9. servisiranje;

10. način ravnanja oziroma uporabe s produktom;

11. navodila za uporabo in

12. vrednotenje produkta.

Koncept marketinškega spleta $\gg 4 P \ll$ (angl.: product-price-place-promotion oziroma slovensko: produkt-cena prodaja-promocija), kot ga poznamo danes naj bi prvič predstavil Jerome McCarthy. 
Po letu 1980 so bile po vzoru koncepta 4P po McCarthy-ju iz šestdesetih let razvite številne različice koncepta marketinškega spleta. V večini njih se je po vzoru izvorne teorije pojavljala črka P (npr: 7P, v kateri je bilo konceptu 4P dodano še: procesiranje, ljudje in fizični dokazi-angl.: process, people and physical evidence. Tudi koncept $7 \mathrm{P}$ je bil kasneje modificiran v koncept 8P. Osmi $\mathrm{P} v$ angleščini pomeni »performance«, kar odraža kakovost izvedbe.

Koncept marketinškega spleta je relativno enostavno razumljiv. Uporaben je v vsakdanji managerski praksi. Na enostaven način opredeljuje, kako zadovoljiti potrošnika. Managerjem omogoča ločitev funkcije marketinga od ostalih poslovnih funkcij $\mathrm{v}$ podjetju, hkrati pa omogoča delegiranje opravil v zvezi z marketingom specialistom.

Koncept marketinškega spleta ima torej številne dobre lastnosti, zato je deloval več desetletij. Kljub nedvomnim prednostim in enostavni uporabi koncepta marketinškega spleta, je ta koncept doživel številne kritike. Ključna kritika je ta, da je marsikatera organizacija koncept razumela in prakticirala zgolj kot način za agresivno prodajo izdelkov. Poznamo številne primere agresivnih oglaševalskih kampanj, akcijskih cen in uporabe znanih obrazov za promocijske namene, katerih primarni namen ni bil zadovoljiti potrošnika, pač pa zgolj prodaja.

Chai Lee Goi (2009) našteva še nekatere druge slabosti:

- Koncept marketinškega spleta je v prvi vrsti namenjen marketingu industrijskih proizvodov, manj pa marketingu storitev. To je bilo sicer kasneje modificirano s konceptom $7 \mathrm{P}$ oziroma $8 \mathrm{P}$.

- Specialisti za marketing so ob uveljavitvi tega koncepta postanli središče dogajanja v podjetju. Vplivati so začeli tudi na tehnične prvine, kot je razvoj produktov.

- Koncept je orientiran v podjetje in ne upošteva behaviorizma potrošnikov.

- Koncept ne predvideva simetričnega dvosmernega odnosa med proizvajalcem in potrošnikom.

- Koncept ne omogoča povratne informacije potrošnikov o kupljenem produktu.

Do preloma pri izobraževanju o marketingu je prišlo po letu 1959. Ekonomista Robert Gordon in James Howell sta v poročilu Higher Education for Business ostro kritizirala dotedanje poslovno izobraževanje v ZDA. Zahtevala sta bolj strog pristop k raziskavam in k izobraževanju na področju trženja. (Winer, Neslin, 2014).

Posledično so bile po letu 1960 v ZDA v programe poslovnih fakultet uvedene vsebine:

- uporaba matematičnih modelov;

- stohastični modeli;

- uporaba kvantitavnih metod. 
Že kmalu so bile uporabljene tudi v praksi:

- Opravljeni so bili poskusi vrednosti informacij simuliranih v realnih okoljih.

- Začelo se je empirično merjenje učinkov oglaševanja.

- Za preučevanja prehoda potrošnikov med različnimi blagovnimi znamkami so se začele uporabljati Markovske verige.

- Za preučevanje izbire blagovne znamke so se začeli uporabljati verjetnostni modeli.

- Za izbor medijev za oglaševanje se je začelo uporabljati linearno programiranje.

Raziskave niso potekale zgolj v okviru matematičnih metod in operacijskih raziskav, pač pa tudi širše. Winer in Neslin, (2014) navajata, da so se po letu 1968 pojavile nove perspektive raziskovanja marketinga:

- delo na segmentaciji trga;

- raziskovanje življenjskega cikla izdelka;

- razvoj novih izdelkov;

- opredelitev trga;

- raziskovanje vpliva marketinških strategij na dobičkonosnost podjetja.

Sredi sedemdesetih let prejšnjega stoletja pa so se pojavile nove prioritete raziskovanja:

- raziskovanje tržnih deležev;

- ekonomika oglaševanja, npr.: študije ekonomske učinkovitosti televizijskih oglasov;

- študije navad potrošnikov (npr.: napovedovanja nakupovalnega obnašanja potrošnikov);

- razvoj elektronskih terminalov (npr. TV prodaja) in

- kontrola zalog na drobno.

Po letu 1980 so se pojavili osebni računalniki. Leta 1986 je bil izdelan prvi program oziroma prva baza podatkov, namenjena stikom s kupci. Po letu 1991 se je začel razširjati še internet. Internet je sprva pomenil zgolj novo orodje za boljše udejanjanje koncepta marketinškega spleta:

- Popolnoma se je spremenila pojavna oblika nekaterih produktov (npr.: tiskarski izdelki so se začeli pojavljati v elektronski obliki).

- Internet je postal nov kanal promocije in začel izrinjati dotlej obstoječe kanale (npr.: tisk). V ZDA je bilo v letu 2007 za spletno oglaševanje porabljenih že 21.4 milijard dolarjev. (Harden, 2009).

- Z razvojem orodij za e-nakupovanje je internet postajal tudi nov način prodaje. Harden (2009) npr. navaja, da je raziskava na vzorcu 26.312 ljudi v 48 državah pokazala, da v povprečju $48 \%$ uporabnikov interneta kupuje knjigo izključno preko spleta. Ahava (2014) celo pravi, da internet postaja moderna tržnica.

- E-bančništvo je omogočilo drugačen način plačevanja. 
Z masovno uporabo interneta so nastala družbena omrežja: LinkedIn (2002), Myspace (2003), Facebook (2004) in Twitter (2007). Družbena omrežja so omogočila, da ponudniki dobrin ostanejo $\mathrm{v}$ stalnem stiku $\mathrm{z}$ odjemalci. Marketing je dobil nove razsežnosti. Mnogi so pojav interneta izkoristila zgolj za še bolj agresivno promocijo produktov.

Gledano dolgoročno, internet pomeni novo paradigmo, ki presega desetletja uveljavljen koncept marketinškega spleta. Teoretično gledano je internet ponudil možnost, da so se sploh prvič udejanile idealizirane zamisli koncepta marketinga. Ne smemo pozabiti, da so temeljne ideje koncepta marketinga $\mathrm{v}$ tem, da se zadovolji kupec. Uporaba interneta to omogoča, saj preseže dotedanje omejitve realnih danosti. Hkrati odpravi številne slabosti do tedaj uveljavljenega koncepta marketinškega spleta:

- Z enostavnim spletnim dostopom do množice globalnih ponudnikov se poveča svoboda izbire potrošnika, katero je dotlej omejevala geografska lokacija.

- Interaktivnost omogoča dejansko individualnost kupca pri iskanju in celo konfiguriranju produktov. Stopnja razvitosti proizvodnje hkrati omogoča hitro izdelavo individualiziranega produkta.

- Interaktivnost elektronskega bančništva omogoča individualno konfiguracijo plačilnih pogojev.

- Marketing ni več prvenstveno orientiran v podjetje. S tem, ko je preko spletnih aplikacij potrošniku ponujena dejanska možnost velike izbire in celo konfiguriranja produkta, se podjetje dejansko lahko orientira v potrošnika.

- Internet podjetjem omogoča, da pred, med in po nakupu ostanejo v nenehnem stiku s potrošniki.

- Olajšana je pomoč uporabnikom.

- Internet podjetjem omogoča povratne informacije potrošnikov.

- Omogočena je personifikacija sporočil.

- Metode raziskave postanejo cenejše.

Tako za ponudnike dobrin kot za kupce internet prinaša tudi precej nevarnosti:

- Večno aktualno je vprašanje splošne spletne varnosti.

- Poveča se obseg neželenega komuniciranja organizacij. Pojavljajo se spletne trgovine, ki niso vredne zaupanja.

- Pojavlja se vprašanje verodostojnosti sporočil.

- Mnogo bolj kot kadarkoli je aktualno vprašanje zaščite intelektualne lastnine (npr.: audio in video izdelkov, programske opreme, izdelkov uveljavljenih blagovnih znamk).

- Bolj kot kadarkoli je aktualna problematika komunikacijske preobremenitve potrošnikov. 


\section{DRUŽBENO ODGOVORNA ORGANIZACIJA}

Družbeno-odgovorna organizacija je prehodna stopnja v razvoju od marketinške $\mathrm{k}$ percepcijski organizaciji.

Izraz »družbena odgovornost« podjetij pomeni, da podjetja prostovoljno prevzemajo odgovornost za različna družbena, gospodarska, ekološka in kulturna vprašanja. Ideja, naj bi se podjetja ukvarjala tudi z temi problemi, sega v 19. stoletje. V tem obdobju so podjetja začela delavcem nuditi bivalne prostore $\mathrm{v}$ naseljih ob tovarnah.

Izraz "družbena odgovornost" prvič uporabil Howard Bowen leta 1953 v knjigi Social Responsibilities of the Businessman. (Demmerling, 2015).

Od prve omembe so nastale številne definicije pojma »družbena odgovornost«. Dahlsrud (2008) jih je analiziral kar 37. Ugotavlja, da večina od njih deli tri glavne razsežnosti družbene odgovornosti:

- Socialna razsežnost družbene odgovornosti odraža odnos med podjetjem in družbo kot celoto. Vključuje tudi odnos do zaposlenih in prakticiranje načel pravične trgovine.

- Okoljska razsežnost družbene odgovornosti se nanaša na vpliv podjetja na okolje in na rabo obnovljivih virov energije.

- Gospodarska razsežnost družbene odgovornosti se nanaša na odgovornost za poslovni izid. Ta naj bo seveda dobiček. Nanaša se pa tudi na druge socialnoekonomske ali finančne vidike poslovanja, vključno z opisom odgovornosti za vse poslovne operacije.

Ob obravnavi definicij družbene odgovornosti se pogosto omenja »Carroll-ova piramida«. Carroll (1979) v njej navaja hierarhijo štirih odgovornosti podjetja:

1. Gospodarska odgovornost je zavezujoča. Prva obveznost in odgovornost podjetja je, da bo dobičkonosno. Dobičkonosnost je edini način za preživetje podjetja, kar na dolgi rok koristi tudi družbi.

2. Pravna odgovornost je zavezujoča. To je obveznost, da spoštovanja zakonov in predpisov.

3. Etična odgovornost je prostovoljna. To je odgovornost in pripravljenost, da podjetje deluje moralno in etično.

4. Človekoljubna odgovornost je prostovoljna. To je odgovornost in pripravljenost, da podjetje del dobička vrne nazaj v družbo. Odgovornost je diskrecijska, vendar je še vedno pomembna.

Milton Friedman (1970) je trdil, da je taka usmeritev podjetij pot v socializem in da je v nasprotju s svobodnim podjetništvom. Nasprotno temu se kot nadgradnja obstoječih 
konceptov družbene odgovornosti že pojavljajo zametki pristopa TRM (Total Respect Management). To je strategija, metoda in filozofija managementa, ki temelji na vodenju, upravljanju (nevarnosti) in odličnosti.

Avtor piramide družbene odgovornosti Archie Carroll je več let po prvi objavi piramide celo sam ugotovil, da je njegova piramida zgrajena na "idealu" in s predpostavko, da podjetja delajo dobro in da ne naredijo nobene škode za naravo in družbo. Resnica pa je, da niso vsa podjetja "dobra" in da je posel lahko tudi "slab«. Podjetja lahko manipulirajo svoje dobavitelje in odjemalce, izkoriščajo delavce, podkupujejo vladne uradnike, neetično lobirajo zakonodajalce in vlade ter onesnažujejo okolje, da pridobijo več dobička na račun drugih. To je resnično vprašanje družbene odgovornosti podjetij in velika skrb za javnost od industrijske revolucije v 19. stoletju dalje (Carroll, 2008).

Kljub različnim razmišljanjem, so se mnoga podjetja vendarle začela obnašati družbeno odgovorno. Demmerling (2015) navaja naslednje razloge:

- Moralno-etični razlogi, s katerimi tudi podjetja želijo pokazati, da je to dolžnost (kar je sicer $\mathrm{v}$ nasprotju z neoklasično ekonomsko doktrino, ki pravi, da je družbena odgovornost podjetja to, da posluje $z$ dobičkom).

- Prevencija pred ovirami in omejitvami: podjetje z družbeno-odgovornim ravnanjem deluje proaktivno in preventivno. To krepi pozitivno podobo podjetja v družbi in s tem zmanjšuje kritike in možnosti zakonskih omejitev.

- Pritisk družbe in ugled: številni posamezni primeri kažejo, da so se podjetja dovolj zgodaj odzvala na pritisk v zvezi z socialnimi in ekološkimi problemi, da se je preprečila eskalacija zaradi protestov in medijev.

- Strateški poslovni razlogi: podjetja strateško izvajajo družbeno odgovorne aktivnosti iz razloga, ker se zavedajo, da te aktivnosti potrošniki prepoznajo. $\mathrm{Z}$ drugimi besedami, $\mathrm{z}$ družbeno odgovornim ravnanjem podjetja pridobijo naklonjenost potrošnikov in s tem povečajo svoj dobiček.

$\mathrm{Na}$ to, da je koncept družbene odgovornosti podjetij postal tako pomemben, je vplivalo tudi to, da so mednarodne organizacije izdali svoje smernice. Teh standardov in smernic je več:

\section{UN GLOBAL COMPACT:}

Združeni narodi so leta 2000 ustanovili združenje United Nations Global Compact,. To je največja globalna pobuda za družbeno odgovornost in trajnostni razvoj. Izhajajoč iz:

- Univerzalne deklaracije o človekovih pravicah (Universal Declaration of Human Rights);

- Dokumentov mednarodne organiazcije za delo (ILO's Declaration on Fundamental Principles and Rights at Work) in

- Konvencije Združenih narodov proti korupciji 
je UN Global Compact sprejel 10 principov poslovanja, ki se nanašajo na:

- $\quad$ splošne človekove pravice;

- pravice na delovnem mestu;

- varstvo okolja in

- preprečevanje korupcije.

\section{FAIRTRADE INTERNATIONAL}

Organizacija Fairtrade International je neprofitno združenje. Sedež ima v Bonnu v Nemčiji.

Pobuda Fairtrade etike je prišla leta 1988. Tega leta so na Nizozemskem začeli prodajati kavo z etiketo Fairtrade. Bistvo pobude je bilo v nasprotovanju izkoriščanja pobiralcev kave na plantažah. Predhodnica današnje organizacije je bila ustanovljena leta 1997 pod imenom Fairtrade Labeling International.

Fairtrade je alternativni pristop k trgovini. Temelji na partnerstvu med proizvajalci in potrošniki.

\section{ISO STANDARDI}

Mednarodna organizacija za standardizacijo (International Organization for Standardization - ISO) je leta 2010 izdala dokument Napotki za družbeno odgovornost (Guidance on Social Responsibility).

ISO 26000:2010 je standard, ki ponuja smernice o tem, kako lahko podjetja in organizacije delujejo na družbeno odgovoren način. Družbena odgovornost po ISO 26000 pomeni, da podjetje deluje na etičen in pregleden način, ter prispeva k zdravju in blaginji družbe. ISO 26000: 2010 zagotavlja smernice in ne zahtev. V nasprotju z nekaterimi drugimi standardi ISO se po standadu ISO 26000:2010 ni mogoče certificirati. Standard zgolj pomaga razjasniti, kakšna je družbena odgovornost. Namenjen je vsem tipom organizacij, ne glede na njihovo dejavnost, velikost ali lokacijo.

ISO 14000 pa je družina mednarodnih standardov glede ravnanja z okoljem.

\section{EFQM}

EFQM (European Foundation for Quality Managemen) je model poslovne odličnosti. Pri modelu EFQM gre za širši, bolj kompleksen model poslovne odličnosti, ki se navezuje tudi na zaposlene, na okolje in na družbo. Po modelu EFQM obstaja 5 meril za področje dejavnikov in 4 merila za področje rezultatov. Merila dejavnikov so stvari, ki jih mora organizacija storiti za svoj razvoj:

- voditeljstvo;

- strategija; 
- zaposleni;

- partnerstva in viri ter

- procesi, izdelki in storitve.

Merila rezultatov pa so:

- rezultati povezani z odjemalci;

- rezultati povezani z zaposlenimi;

- rezultati povezani z družbo;

- rezultati poslovanja.

Poleg vseh že navedenih razlogov v prid družbeno odgovornemu ravnanju McElhaney (2008) navaja še nekatere druge razloge, da družbena odgovornost postaja stalnica poslovnega razmišljanja:

- Tehnologija ljudem omogoča takojšen dostop do informacij.

- Povrečal se je vpliv nevladnih organizacij.

- Prišlo je do prerazporejanja sredstevin kupne moči od vlad in javnega sektorja proti zasebnem sektorju.

- Sindikati so postali zelo močni.

- Na svetu je vse večja.ponudba dobrin.

Koncept družbene odgovornosti je pomemben tudi $\mathrm{z}$ vidika zadovoljevanja potreb kupcev. V evoluciji organizacij je klasično prodajo nadgradil marketing. Otr sno že pojasnili, je bistvo marketinga $\mathrm{v}$ zadovoljitvi potreb, želja in pričakovanj potrošnikov. V sodobni družbi pa se zaznave in pričakovanja potrošnikov ne nanašajo zgolj na pričakovanja, povezana z elementi marketinškega spleta, pač pa širše. Obstaja namreč več raziskav, ki dokazujejo, da družbeno odgovorno oziroma družbeno neodgovorno ravnanje organizacij vpliva na behaviorizem potrošnikov.

Demmerling (2015) ugotavlja naslednje:

- Zavedanje družbene odgovornosti in s tem povezanih akcij podjetij je med potrošniki sicer zelo različno.

- Študije kažejo, da ima negativna informacija (ali slaba novica, ki je povezana z družbeno odgovornostjo podjetja) veliko večji vpliv na zavest potrošnika, kot katerakoli druga. Negativna informacija spodbudi negativna čustva, ta pa negativno reakcijo.

- Pozitiven vpliv družbene odgovornosti podjetij na behaviorizem potrošnikov je lahko neposreden ali posreden. Posreden je, ko potrošniki poznajo podjetje in njegove družbeno odgovorne dejavnosti. Na ta način se ustvari kontekst za nakupno namero. Neposreden pa je, kadar se družbeno-odgovorne pobude podjetja skladajo s prepričanji potrošnikov. V takih primerih podjetje potrošnike neposredno vplete v podporo pobudam. 
Raziskavo o tem, kako na družbeno odgovorno ravnanje podjetij gledajo potrošniki, so opravili tudi Rosario González-Rodríguez in soavtorji (2015). V svoji raziskavi so upoštevali samo tri dimenzije družbene odgovornosti: finančno, socialno in okoljsko. V pripravah na svojo raziskavo so opravili natančen pregled predhodnih raziskav od leta 1978 dalje. Potrjujejo isto, kot je ugotovil že Demmerling. Z vidika dojemanja družbene odgovornosti podjetij so si potrošniki med seboj zelo različni. Lahko so altruistični (izražajo solidarnost) ali pa egoistični. Rezultati te raziskave pa vseeno kažejo, da človeške vrednote kupcev vplivajo na dojemanje družbene odgovornosti podjetij. 
Stopnje razvoja organizacij 


\section{PERCEPCIJSKE ORGANIZACIJE}

\section{Nastanek percepcjskih organizacij}

\section{Percepcijska organizacija je organizacija, ki pri izvrševanju namena svojega obstoja sistematično upravlja s svojo identiteto.}

Razlika med percepcijsko organizacijo in marketinško organizacijo je v tem, da se zagotavljanje zadovoljstva strank marketinške organizacije nanaša na produkt in vse, kar je s produktom povezano (npr. cena, distribucija, idr.). Pri percepcijski organizaciji pa ne gre zgolj za odnos organizacije do strank, pač pa za odnos do ljudi v širši skupnosti. Zagotavljanje zadovoljstva se ne nanaša zgolj na produkt in elemente, ki so z njim povezani, pač pa na identiteto organizacije kot celote.

Ravnanje, to je behaviorizem posameznikov in skupin iz okolja, je povezano s tem, kako ti posamezniki ali skupine percepirajo celotno organizacijo, to je njeno identiteto. Številne empirične raziskave od leta 1995 dalje kažejo, da image organizacije direktno vpliva na zadovoljstvo in lojalnost strank. To so ugotovili raziskovalci v različnih delih sveta.

- Tor Wallin Andreassen in Bodil Lindestad sta leta 1998 opravila raziskavo na vzorcu 600 uporabnikov turističnih storitev na Norveškem. Pomemben dejavnik zadovoljstva strank je bil image turistične agencije.

- Jay Kandampully in Dwi Suhartanto sta leta 2000 na Novi Zelandiji ugotovila, da sta ključna elementa za ponovni nakup image produkta in zadovoljstvo $\mathrm{s}$ produktom. Pri odločitvi za ponoven nakup cena sploh ni bila pomembna.

- Podobno so leta 2009 na primeru raziskave trga telekomunikacijskih storitev na Kitjaskem ugotovili Fujun, Ali in soavtorji, Minkiewicz in soavtorji (2011 v Avstraliji, Hashim in soavtorji (2015) v Pakistanu in drugi.

Management identitete organizacije (Corporate Identity Management - CIM) je strateško in operativno upravljanje poslovanja in optimizacijo zunanjega percepcije organizacije. Cilj managementa identitete organizacije je doseči visoko povezanost med percepcijo organizacije $\mathrm{v}$ okolju in dejansko identiteto organizacije. Idealno bi bilo, da ima identiteta organizacije enake vrednote kot njene javnosti in ciljne skupine v okolju. $\mathrm{S}$ tem bi si organizacija omogočila identifikacijo in poistovetenje z družbo. (Herbst, 2009).

Če se ozremo v zgodovino zadnjega stoletja in se osredotočimo na podjetja, smo ugotovili, da so bile organizacije v začetni stopnji svojega razvoja osredotočene na proizvodnjo. Sčasoma se je pozornost preusmerila na prodajo in organizacije so se osredotočile na produkte. 
Po industrijski revoluciji se je na trgu pojavila množica dobrin. Marketing je postal desetletja delujoč koncept, ki je prinesel družbeni, tehnološki in civilizacijski napredek ter gospodarsko rast.

Resnici na ljubo je treba spet izpostaviti, da v praksi sploh ni bilo vedebo nujno, da bi si organizacije v resnici in iskreno prizadevale za to, da bi bil kupec res zadovoljen. Številni primeri prakse marketinga kažejo tudi na to, da je bil marketinški splet oblikovan zgolj z namenom prepričati kupca $\mathrm{v}$ nakup. Opazimo lahko številne primere agresivnega oglaševanje z namenom spodbujanja kupca k nakupu. Pri tem sploh ni nujno, da produkt v čemerkoli zadovolji kupca. Celo nasprotno. Če v takih primerih kupec slučajno ugotovi, da nekaj vendarle ni v redu, se ga lahko celo prikazuje za zahtevno stranko ali celo za čudaka. Taki primeri so bili v preteklosti možni zgolj zaradi pomanjkanja informacij kupcev.

Kupci pred nakupom informacije navadno iščejo pri zasebnih in pri poslovnih virih. Pomemben poslovni vir informacij je bil v preteklosti vezan na medije. Klasične obliki komuniciranj organiazcij z okoljem sta bili oglaševanje in odnosi z javnostmi. Kasneje so se pojavili še odnosi z vlagatelji in krizno komuniciranje. Na vse to so organizacije imele vpliv. Še pred desetletji sploh ni bilo nujno, da bi kupec sploh lahko o organizaciji izvedel karkoli takega, kar organizacija ne bi želela. Okolje je bilo namreč bolj ali manj vezano na informacije iz poslovnih virov. Možnost širjenja informacij o organizaciji prek zasebnih virov je bila glede na današnji čas relativno majhna. Informiranost ljudi je bila pogojena z dosegom medijev, $\mathrm{z}$ možnostjo dostopa do medijev in z nadzorom nad mediji.

V začetnem obdobju marketinga so obstajali zgolj tiskani mediji, kasneje pa sta se pojavila še radio in televizija. Mediji niso bili niti razviti, niti dostopni do te mere, da bi kupec sploh lahko imel dostop do take množice informacij o organizaciji, kot jih ima danes . Doseg in dostop do tiskanih medijev, do radia in televizije sta bila skozi zgodovino pogojena:

- s stopnjo razvitosti medijske infrastrukture;

- s stopnjo razvitosti logistične infrastrukture, ki je vplivala na distribucijo;

- s tehničnimi omejitvami distribucije RTV signalov;

- s kupno močjo posameznika.

Organizacije so imele možnost vplivati tako na vsebino objavljenih informacij, kot tudi na dinamiko objav. Moč za vpliv na medije je izviral:

- iz povezav z lastniki medijev;

- iz odvisnosti medijev od oglaševanja.

Organizacije so vsebine in dinamiko objav do neke mere lahko upravljale $\mathrm{z}$ uporabo orodij odnosov z javnostmi. 
S pojavom interneta in socialnih omrežij so se stvari popolnoma spremenile. Internet je postal splošno dostopen medij tako za sprejemanje, kot za oddajanje informacij. Nastala so socialna omrežja, številni forumi, blogi, povečala se je stopnja aktivizma potrošnikov. $\mathrm{S}$ tem se je povečala možnost pridobivanja informacij iz zasebnih virov. Potrošniki in drugi zainteresirani kar naenkrat niso več odvisni zgolj od informacij o organizacijah iz poslovnih virov. Distribucija informacij preko interneta tudi ni več vezana na lastnike medijev. Organizacije na to, katere vsebine o organizaciji, kdaj in v kakšni obliki bodo objavljene na raznih forumih, blogih, specializiranih spletnih straneh ne morejo več vplivati. Okolje neprestano zaznava identiteto organizacij in jo ima možnost kadarkoli razkriti.

Vse to pa ne pomeni, da je $\mathrm{s}$ tem konec koncepta marketinga in odnosov z javnostmi. Tako marketing kot odnosi $\mathrm{z}$ javnostmi seveda ostajata sestavni del koncepta percepcijske organizacije.

Kar se tiče marketinga je za percepcijsko organizacijo pomembno, da se praksa vrne k temelju koncepta marketinga. To pa je zagotoviti zadovoljstvo kupca.

Cilj odnosov z javnostmi percepcijske organizacije ni in ne more biti zgolj skrb za dober image. Odnosi $\mathrm{z}$ javnostmi so dvosmeren proces, katerega namen je sporazumetje organizacije in okolja.

\section{Identiteta organizacije}

Identiteta organizacije je vse tisto, kar organizacija $\mathrm{v}$ resnici je in kar je $\mathrm{v}$ zvezi $\mathrm{z}$ organizacijo možno zaznati. Skozi zgodovino so se pokazali številni primeri človeških skupnosti, ki bi bili brez identitete skupnosti nezmožni golega preživetja. Na podlagi skupne identitete so se $\mathrm{v}$ zgodovini oblikovala plemena, narodi, verske skupnosti in države. Identiteta je v zgodovini lahko pomenila celo pogoj za biološko kontinuiteto. ${ }^{14}$ Sestavine identitete so bile npr.: jezik, vladar, vera, in lahko celo sovraštvo do druge skupine. Identiteta je predstavljala notranjo kohezivno silo skupnosti. Pogosto je bilo dovolj že to, da je na tak ali drugačen način izostal samo eden od elementov identitete in skupnost je propadla. Iz zgodovine pa so poznani številni primeri, ko je bila skupnost na tak način celo biološko uničena. Prav zaradi ogroženosti biološkega preživetja se je diskurz identitete pogosto prilagajal. Tipičen primer zaznavamo na ozemlju nekdanje države SFR Jugoslavija, kjer se je identiteta političnih entitet popolnoma spremenila.

Koncept identitete organizacije se je prvič pojavil po letu 1950, vendar desetletja ni zaživel. Veliko organizacij ni čutilo nobene potrebe, da bi koncept udejanile. Stvari so se popolnoma spremenile s pojavom interneta. Internet je omogočil hitro širjenje želenih in tudi neželenih informacij o organizacijah.

${ }^{14}$ Več o tem glej npr.: (Sabaté, 2015). 
Balmer in Greyser (2013) navajata pet faz razvoja koncepta identitete organizacije:

- Obdobje od 1950 do 1970: Organizacije so se fokusirale na svoj image.

- Obdobje od 1970 do zgodnjih osemdesetih let: Organizacije so se še vedno fokusirale na svoj image, začele pa so se fokusirati tudi na svojo identiteto.

- Pozna osemdeseta leta do 2000: Organizacije so se fokusirale na svoj image, na svojo identiteto, začele pa so tudi s korporacijskim komuniciranjem.

- Po letu 2000: Organizacije so se fokusirale na brand-iranje organizacije.

- Prihodnost: Organizacije bodo fokusirane na svojo identiteto.

Balmer in Greyser (2013) pravita, da je pri razvoju identitete organizacije najprej treba odgovoriti na tri vprašanja:

- Centralni fokus: Katere so bistvene lastnosti organizacije?

- Razlikovanje od drugih: Katere lastnosti organizacijo ločujejo od drugih organizacij?

- Kontinuiteta: V čem je organizacija skozi obdobje svojega obstoja bila unikatna?

Balmer in Greyser (2013) nadalje navajata nalsednja vprašanja identitete organizacije:

- Katere so glavne značilnosti organizacije?

- S kom in v zvezi s čim mora organizacija komunicirati?

- Kaj je poslanstvo organizacije in s čim je organizacija zavezana okolju?

- Kaj povezuje člane organizacije in do česa imajo člani organizacije afiniteto?

- Kako je bila organizacija skozi čas percepirana v okolju?

- Kako je organizacija v okolju percepirana danes?

Balmer in Greyser (2013) pravita, da v vsaki organizaciji lahko obstaja pet različnih tipologij identitet:

Dejanska identiteta organizacije je rezultanta vrednot organizacije. Navzven se odraža v številnih pojavnih oblikah:

- ime organizacije;

- lastništvo oziroma ustanoviteljstvo organizacije;

- management;

- zaposleni;

- stavbe in prostori;

- stil vodenja;

- organizacijska struktura;

- značilnosti izvajanja poslovnih funkcij;

- imena, kakovost ter vsi ostali zaznavni atributi proizvodov in storitev;

- poslovni rezultati;

- drugo. 
Idealna identiteta organizacije je za organizacijo optimalna percepcija posameznih elementov identitete pri ključnih javnostih in ciljnih skupinah v okolju. Idealne identitete v praksi ni mogoče doseči, saj to omejujejo različni omejitveni dejavniki tako v okolju, kot znotraj organizacije.

Zasnovana identiteta organizacije je s strani managementa organizacije želena in zasnovana percepcija posameznih elementov identitete organizacije pri javnostih in ciljnih skupinah v okolju. Nanaša se na sedanjost in bližnjo prihodnost.

Želena identiteta organizacije je s strani managementa organizacije želena in zasnovana percepcija posameznih elementov identitete organizacije pri ključnih javnostih in ciljnih skupinah v okolju. Nanaša se na srednje in bolj oddaljeno prihodnost.

»Komunicirana« identiteta organizacije se odraža skozi vsebine in kanale komuniciranja organizacije z okoljem. Vsebine in kanali komuniciranja organizacije $\mathrm{z}$ okoljem so kontrolirani in nekontrolirani. Kontrolirane vsebine in kanali komuniciranja organizacije so npr: oglaševanje, odnosi z javnostmi in sponzorstva. Nekontrolirani vsebine in kanali pa so: razni blogi, zapisi na družbenih omrežjih komentarji v medijih, na katere organizacija nima nobenega vpliva.

Poleg naštetega obstaja tudi »pripisana identiteta «. Pripisana identiteta je imaginarna oziroma namišljena. Do pojava poripisane identiutete organizacije pride, kadar drugi subjekti v okolju preko različnih kanalov komuniciranja organizaciji pripisuje značilnosti, katerih organizacija v sedanjosti nima.

$\mathrm{V}$ organizacijah se skozi časovno obdobje lahko identiteta popolnoma spremeni. Iz identitete A nastane identiteta B. Lahko nastane tudi nekaj vmesnega, torej AB. Balmer in Greyser (2013) kot razloge za to navajata prelomne dogodke znotraj same organizacije: Nastanek organizacije pomeni tudi to, da se opredeli: poslanstvo organizacije, cilji, tehnologija, idr.

Dosežki organizacije: organizacija v nekem trenutku mora zaradi zagotavljanja svojega preživetja začeti delati nekaj drugega, kot je bil razlog ustanovitve. Pri tem lahko celo doseže odlične rezultate. To vpliva na centralni fokus organizacije. Tovrstnih primerov sprememb idenbtitete je bilo zelo veliko. Zelo pogsto se omenja primer podjetij Nokia in Samsung. Nokia je bila ustanovljena leta 1865 kot proizvajalec gume. S proizvodnjo elektronike se je začelo ukvarjti šele sto let po ustanovitvi. Podjetje Samsung je bilo ustanovljeno leta 1938. Osnovna dejavnost je bila proizvodnja in izvoz hrane za kitajski trg. Z elektroniko se je podjetje začelo ukvarjati šele leta 1970.

Ekstremno hitra rast lahko že sam po sebi zaradi notranjih razlogov popolnoma spremeni identiteto organizacije.

Sprememba statusa: tako kot v življenju človeka obstajajo prelomni dogodki, kot so: rojstvo, smrt, poroka, ločitev, se tudi v organizacijah lahko lastniki ali ustanovitelji odločijo za spremembe statusa, kot so: ločitev organizacije na več delov, pripojitve, ipd. 
Tovarna zdravil Lek iz Ljubljane je bila ustanovljena leta 1946. Leta 2002 je Lek postal del poslovne skupine Novartis.

Omejevanja: vsaka organizacija ima svoje vzpone in padce. Prihaja tudi do kriz. V krizah je primarna usmeritev varčevanje. To lahko popolnoma spremeni identiteto organizacije.

Poleg prelomnih dogodkov znotraj organizacije na identiteto organizacije vplivajo tudi dejavniki okolja. Pogosto imamo opraviti s pojavom »dualnosti identitete«. To pomeni, da je bilo ob ustanovitvi sicer opredeljeno poslanstvo, cilji in vrednote. Vendar ima organizacija v resnici dve identiteti. V skrajnih primerih ima organizacija lahko celo več identitet.

Organizacija ima lahko že sama po sebi dve ali celo več identitet. Ta pojav je star toliko, kot so stare organizacije. Organizacije po »naravni« poti doživljajo svojo evolucijo. S tem spreminjajo tudi svojo identiteto. Pri tem pride do notranje diferenciacije.

Razlogi za nastanek dveh ali več identitet so lahko objektivni ali subjektivni.

Objektivni razlogi so:

- Organizacija lahko zaradi notranjih ali zunanjih objektivnih dejavnikov pride v krizo. Zato mora spreminjati svojo identiteto. Na pojav krize se ljudje znotraj organizacije različno odzivajo.

- Kompleksnost okolja je dejavnik, ki od vsake organizacije zahteva neprestano prilaganje in adaptiranje identitete na spremembe okolja. Odnos ljudi do sprememb pa je zelo različen.

- Ekstremno hitra rast navadno prinaša tudi pritiske in pričakovanja okolja po različnih sponzorstvih. Pritiski in pričakovanja morda niso skladna s prvotno identiteto organizacije.

- Problem »povrnitve « nastane, kadar organizacija začasno spremeni ali je celo prisiljena spremeniti svojo identiteto. Prepričanja in pričakovanja okolja (npr.: kupcev) do organizacije so vezana na prvotno identiteto. Organizacija zaradi spremembe identitete lahko izgubi ugled in zaupanje kupcev. Ko organizacija želi svojo identiteto povrniti $\mathrm{v}$ izvorno stanje, se pogosto pojavi dvojna identiteta.

Subjektivni razlogi za pojav dvojne identitete so:

- Pojav borbe za prevlado znotraj organizacije.

- Nepravilnosti in škandali znotraj organizacije,

- Zavestno upiranje vplivnih posameznikov ali skupin.

- Maščevanje, sovraštvo, nevoščljivost in drugi nizkotni nagibi.

Pojav dvojne identitete je pogosto vodil v razpad na več delov. V zgodovini pred njim niso bile imune niti organizacije, kot je Cerkev. Primer fenomena take organizacije je bila bivša država SFR Jugoslavija. Zasnovano, želeno in komunicirano identiteto nekdanje 
države bi lahko opisali z besedami »Maršal Tito« ter »bratstvo in enotnost «. V resnici ta država ni imela samo ene identitete, niti dvojne identitete. Imela je celo več celo identitet:

- V državi sta se uporabljali dve pisavi (latinica in cirilca).

- Kot uradni jezik se je uporabljalo več jezikov.

- Državljani so bili pripadniki najmanj treh velikih verskih skupnosti (Rimokatoliška cerkev, Pravoslavna cerkev in Islamska verska skupnost).

Kljub taki raznolikosti je ta država funkcionirala več desetletij.

\section{Image}

Elsbach (2013) pravi, da je image trenutna, vendar začasna percepcija organizacije s strani ljudi. Gre torej za »podobe«, oziroma »mentalne slike«, ki jih imajo ljudje o organizaciji. Organizacija ima v istem času lahko več različnih image-ov. Razlog je v tem, da imajo tako zunanje javnosti kot tudi notranja javnost lahko vsaka svoje podobe o organizaciji.

Elsbach (2013) meni, da je image organizacije sestavljen iz naslednjih dimenzij:

- legitimnost;

- pravilnost in doslednost;

- zanesljivost in

- ugled.

Legitimnost organizacije se kaže $\mathrm{v}$ pravilnosti (skladnosti s pravnimi normami), primernosti in zaželenosti ravnanj organizacije z vidika družbeno sprejetih norm, vrednot, pričakovanj in definicij. Legitimnost se tore ne odraža zgolj v tem, da organizacija pri svojem delovanju spoštuje pravne norme in definicije, pač pa tudi družbeno sprejete vrednote.

Pravilnost in doslednost je osredotočena na delovanje managementa organizacije. Kaže se v delovanju pri izvajanju projektov.

Zanesljivost je lastnost organizacije, da pri svojem delovanju izkazuje:

- kompetence;

- dobrohotnost in

- integriteto.

Kompetence organizacije predstavljajo znanja in zmožnosti organizacije, da doseže svoje cilje.

Dobrohotnost izraža pripravljenost organizacije, da dela dobre stvari.

Integriteta pomeni upoštevanje sprejetih družbenih norm in idealov. 
Ugled (ali reputacija) je percepcija statusne kategorizacije organizacije. Statusna kategorizacija organizacije ima obliko rangiranja (oziroma primerjalnega razvrščanja) organizacij. Nanaša se na zelo različne atribute: zanesljivost, kredibilnost, družbena odgovornost, idr. Pogleda na statusno kategorizacijo organizacij sta lahko dva:

- pogled na resurse organizacije se nanaša na atribute povezane s kapacitetami;

- pogled na položaj organizacije na trgu se nanaša na atribute, s katerimi organizacija vzdržuje tržni delež in konkurenčnost.

Balmer in Greyser (2013) image obravnavajo iz naslednjih štirih perspektiv:

- Dejanski image je image, ki ga o organizaciji dejansko ima.

- Želeni image je image, katerega si organizacija želi imeti sama o sebi.

- Stereotipni image sestavljajo vnaprejšnja prepričanja ljudi o organizaciji.

- Kontekstualni image je image organizacije, ki je del širšega konteksta imagea države, regije, gospodarske panoge, ipd.

Izgradnja image-a se začne s sinhronizacijo podobe, ki si jo o sebi želi imeti organizacija sama in dejanske identitete organizacije. Organizacija mora imeti tako identiteto, kot si želi, da jo percepirajo drugi. Če pride do neskladja med image-om, katerega si o sebi želi imeti organizacija sama in image-om, kot ga o organizaciji dejansko ima, vedno pride do težav za organizacijo. McKnight (2013) enkratne akcije za spremembo image-a organizacije primerja $\mathrm{z}$ liposukcijo pri človeku. Z liposukcijo se iz določenih delov človeškega telesa sicer lahko odstranijo maščobe. $\mathrm{S}$ tem se dejansko spremeni človekov videz. Toda če človek po liposukciji ne bo spremenil svojih prehranjevalnih in gibalnih navad, bo maščobe hitro pridobil nazaj. Sprememba videza bo zgolj kratkotrajna. Podobno velja za organizacije.

\section{Blagovna znamka in brand organizacije}

Miletsky (2009a) pravi, da ljudje v vsakodnevnem pogovoru o blagovnih znamkah povezujemo produkt in podjetje, ki produkt izdeluje ali prodaja. Vendar je med produktom in podjetjem pomembna konceptualna razlika. Eno podjetje lahko na trgu ponuja večje število produktov različnih blagovnih znamk, ki so namenjeni različnim ciljnim skupinam.

Podjetje Volkswagen $A G \mathrm{~s}$ sedežem v Wolfsburgu v Nemčiji vozila proizvaja in prodaja pod blagovnimi znamkami: Volkswagen osebna vozila, Audi, SEAT, SKODA, Bentley, Bugatti, Lamborghini, Porsche, Ducati, Volkswagen gospodarska vozila, Scania in MAN.

V podjetju so razvili skupne platforme vozil. Na skupnih platformah je izdelanih več različnih proizvodov. Vanje je vgrajeno večje število popolnoma enakih komponent. Vendar se produkti izdelujejo $\mathrm{v}$ različnih tovarnah in prodajajo pod razlčinimi blagovnimi znamkami. 
Podjetje Luxottica Group S.p.A s sedežem v Italiji je vodilni svetovni proizvajalec sončnih očal. V lasti ima sedem tovarn sončnih očal: tri na Kitajskem, po eno pa v Italiji, Braziliji, ZDA in v Indiji. Sončna očala prodaja pod več kot 25 imeni blagovnih znamk, med drugim tudi: Ray-Ban, Oakley, Vogue Eyewear, Persol, Oliver Peoples, Alain Mikli, Arnette, Giorgio Armani, Burberry, Bulgari, Chanel, Dolce\&Gabbana, Michael Kors, Prada, Ralph Lauren, Tiffany \& Co., Versace in Valentino. ${ }^{15}$

Podjetja, ki imajo v lasti večje število blagovnih znamk, se pogosto poslužujejo poslovnega modela vertikalne integracije proizvodnje. Podjetje Swatch Group s sedežem v Švici je vodilni svetovni proizvajalec ročnih ur. Komponente za ure proizvaja v več specializiranih tovarnah. Tovarna ETA SA Manufacture Horlogère Suisse tako proizvaja mehanizme, Rubattel\&Weyermann številčnice, Ruedin ohišja, Universo kazalce, itd.

Swatch Group blagovne znamke svojih ur segmentira v štiri razrede blagovnih znamk.

- Osnovni razred: Swatch, Flik Flak.

- Srednji razred: Tissot, Calvin Klein, Balmain, Certina, Mido in Hamilton.

- Višji razred: Longines, Rado in Union Glashütte.

- Prestižni in luksuzni razred: Breguet, Harry Winston, Blancpain, Glashütte Original, Jaquet Droz, Léon Hatot in Omega. ${ }^{16}$

Sploh ni nujno, da ima lastnik blagovnih znamk na razpolago proizvodne kapacitete za proizvodnjo produktov vsake od njih. Isti dobavitelj lahko celo za različne naročnike proizvaja istovrstne izdelke več blagovnih znamk različnih lastnikov.

Lastnik blagovne znamke proizvodne kapacitete lahko zakupi. Obstajajo pa primeri, ko lastnik blagovne znamke zgolj proda pravico uporabe imena svoje blagovne znamke. V takem primeru se s proizvodnjo in distribucijo sploh ne ukvarja.

Pojma »blagovna znamka« in »brand organizacije« je zato treba obravnavati ločeno. »Blagovna znamka« se nanaša na produkt ali na skupino produktov. »Brand organizacije« pa se nanaša na organizacijo kot celoto.

\section{Blagovna znamka}

Blagovna znamka je sistem simbolov produkta, ki ima svoj smoter, namen in funkcijo Simboli so različnih pojavnih oblik:

- ime produkta;

- značilna oblika, barva in embalaža;

- značilni napisi in slike;

- vrednote proizvajalca (npr.: varnost, prestiž, zmogljivost);

\footnotetext{
15 Vir: http://www.luxottica.com/en

${ }^{16}$ Vir: http://www.swatchgroup.com/en/brands_and_companies/production
} 
- atributi kulture;

- osebnost (npr.: simboliko resne osebe, mladostnika, športnika, ...)

- drugo.

Smoter obstoja blagovne znamke je, da za potrošnika predstavlja objekt zaznave. Potrošnik mora zaznati simbole, ki jo sestavljajo. Vendar funkcije blagovne znamke ne moremo šteti zgolj k promociji kot elementu marketinškega spleta, pač pa tudi k "fizičnim dokazom«. Blagovna znamka opozarja, da nekaj »obstaja«. Blagovna znamka deluje, če jo potrošnik opazi. Vendar to ni dovolj. Miletsky (2009) pravi, da je blagovna znaka čustveni »sprožilec«. Zaznava blagovne znamke mora v potrošniku sprožiti pojav čustva.

Čustva kupca, povezana z zaznavo in uporabo blagovne znamke so ${ }^{17}$ :

- Zaupanje je prepričanja kupca, da bo blagovna znamka izpolnila svoje obljube.

- Integriteta je prepričanje v pošteno obravnavo in rešitev problemov, ki bi se utegnili pojaviti.

- Ponos je manifestacija osebne povezanosti uporabnika z blagovno znamko.

- Strast je prepričanje, da je blagovna znamka nenadomestljiva.

Elementi, ki vplivajo na pojav čustev so:

- Obljuba - vezana mora biti na življenjski stil uporabnika ali na simpatije do kulture, zabave, športa, ipd. Zapisana obljuba se imenuje slogan. Slogan povzema tisto, kar blagovna znamka obljublja.

- Osebnost - kupec ima svojo lastno osebnost in blagovna znamka mora vzpostaviti čustveno povezavo z uporabnikom.

- Unikatnost in edinstven tržni delež - lastnosti izdelka neke blagovne znamke morajo biti edinstvene, to je drugačne od ostalih.

LePla in Parker (1999) temu dodajta še asociacije.

Namen obstoja blagovnih znamk je v usmerjanju potrošnika k nakupu. Harsh (2010) pravi, da je blagovna znaka neke vrste »navigacija«, ki usmerja potrošnika.

Blagovne znamke omogočajo kupcem, da $\mathrm{v}$ množici neštetih možnosti najdejo pravi izdelek. Tak namen obstoja blagovnih znamk ni v nasprotju s temeljnim konceptom marketinga, ker koristi ne prinaša zgolj lastniku blagovne znamke, pač pa tudi kupcu. Harsh (2010) našteva naslednje:

- Denarne koristi: nakup napačnega izdelka za kupca predstavlja nepotreben izdatek. 
- Časovne koristi: z nakupom izdelka določene blagovne znamke kupec ne izgublja časa $\mathrm{z}$ iskanjem izdelka.

- Zmanjšanje fizičnega napora -iskanje pravega izdelka po trgovinah pomeni fizičen napor.

- Zmanjšanje psihološkega napora - iskanje pravega izdelka po trgovinah pomeni psihičen napor.

Miletsky (2009) pravi, da je blagovna znamka vsota vseh potrošnikovih pričakovanj o produktu ali storitvi po ugledu in po pričakovanih koristih.

Funkcija blagovne znamke je tudi zmanjšati negotovost kupca pri sprejemanju odločitev o nakupu. (Slade, 2016).

Skrbno izbrano ime blagovne znamke lahko prinese naslednje prednosti:

- Moč ga je pravno zaščititi.

- Ljudje si blagovno znamko zapomnijo.

- Predstavlja način za razlikovanje od konkurence.

- Opisuje lastnosti produktov.

- Vzbuja pozitivne asociacije.

Blagovno znamko lahko potrošniki percepirajo tudi kot nekaj negativnega. Negativna konotacija blagovne znamke je posledica kognitivne disonance. Kognitivna disonanca je v psihologiji že dolgo znan in v literaturi pogosto opisan pojav. Gre za razliko med osebnimi pričakovanji in spoznano realnostjo.

Da bi pridobili individualno pravico uporabe blagovne znamke, jo je treba pravno zavarovati. Vprašanja pravnega varstva urejajo mednarodni pravni akti. Prvi tak pravni akt je "Madridski aranžma o registraciji blagovnih znamk", podpisan že leta $1891 \mathrm{v}$ Madridu. Ta akt je bil kasneje večkrat dopolnjen. Ratificirala ga je tudi bivša SFR Jugoslavija, protokole, ki izhajajo iz madridskega aranžmaja pa tudi Republika Slovenija. Zahtevek za varstvo blagovne znamke se vloži pri Uradu Republike Slovenije za intelektualno lastnino.

Prva registrirana blagovna znamka na svetu sploh je bila Coca Cola. registrirana je bila leta 1893, torej komaj dve leti po podpisu "madridskega aranžmaja o registraciji blagovnih znamk «.

\footnotetext{
${ }^{18}$ Več o tem glej v: Uredba o ratifikaciji madridskega aranžmaja o mednarodnem registriranju znamk z dne 14. aprila 1891, revidiranega 14. decembra 1900 v Bruslju, 2. junija 1911 v Washingtonu ..., Uradni list SFRJ številka 2/1974 in Zakon o ratifikaciji protokola k madridskemu sporazumu o mednarodnem registriranju znamk, Uradni list Republike Slovenije številka 21/1997.
} 


\section{Brand organizacije}

Brand organizacije se nanaša na organizacijo kot celoto. Je kolekcija vseh zaznanih podob, ki so jih o organizaciji ljudje zaznali od preteklosti do sedanjosti. (McKnight, 2013). Vključuje elemente image-a in identitete organizacije.

Fenomen branda organizacije izhaja iz fenomenov človekovega zaznavanja vseh atributov organizacije in njihove percepcije ter kognicije.

Branda organizacije ni mogoče ustvariti $\mathrm{z}$ eno samo podobo ali z nekaj podobami $\mathrm{v}$ zelo kratkem časovnem obdobju. Brand organizacije se oblikuje skozi daljše časovno obdobje.

Razlika med image-om organizacije in brandom organizacije je $\mathrm{v}$ tem, da se:

- image organizacije nanaša na tekoče časovno obdobje;

- brand organizacije oblikuje samo skozi daljše časovno obdobje.

LePla in Parker (1999) pri definiciji branda organizacije izhajata iz strategije organizacije. Pravita, da je brand organizacije organizacijska strategija. Uporablja se pri vodenju podjetja kot celote in pri razvoju izdelkov. Organizacija mora iti v smer, kjer vsi ukrepi in sporočila temeljijo na vrednosti, ki jo podjetje prinaša svoji panogi in na vrednosti, ki jo imajo kupci za pomembno.

Videti je, da koncept »branda organizacije« izvira iz koncepta marketinga. Sčasoma je koncept branda organizacije prerasel okvire marketinga. Pričakovanja potrošnikov se namreč ne nanašajo zgolj na elemente marketinškega spleta, pač pa tudi na lastnosti, ki se nanašajo na organizacijo. Te lastnosti so: družbena odgovornost, vrednote in širše.

Blagovna znamka produkta je torej zgolj eden od elementov branda organizacije. Kot pravita LePla in Parker (1999) transparentna blagovna znamka lahko izhaja samo iz organizacije, ki ima:

- opredeljeno poslanstvo;

- svoje vrednote in

- svojo »zgodbo« oziroma zgodovino.

Slade (2016) pravi, da brand organizacije vsebuje tudi »obljubo «. Podobno, kot obljuba blagovne znamke, je tudi obljuba branda organizacije lahko zapisana ali nezapisana. Obljuba branda organizacije je veliko več kot ime, logotip, simbol ali poreklo produkta. Delujejo kot nenapisana pogodba zagotovil.

Osebnost, obljuba in asociacije neke blagovne znamke ne morejo izhajati iz katerekoli organizacije, sploh pa ne iz take, ki ima drugačno »zgodbo«, kot jo predstavlja blagovna znamka produkta. 
LePla in Parker (1999) navajata številne koristi koncepta branda organizacije za notranje procese v organizaciji. Koristi za notranje procese so:

- konsistentnost organizacije pri razvoju novih produktov;

- jasna strategija poslovnih politik, usmerjena v zadovoljevanje potreb na trgu;

- konsistentno notranje in zunanje komuniciranje;

- visoka stopnja lojalnosti zaposlenih;

- večja iniciativnost zaposlenih.

Koristi koncepta branda organizacije navzven pa so:

- sposobnost za doseganje cene produktov, ki je višja od povprečne cene za primerljiv izdelek;

- krajši čas za odločitev stranke za ponovni nakup;

- višja raven zvestobe strank;

- sposobnost ohranjanja tržnega deleža;

- manj nihanj cen izdelkov.

Branda organizacije z enim dogodkom torej ne moremo ustvariti, lahko, vendar ne nujno, pa se že z enim samim dogodkom uniči. McKnight (2013) navaja primer, ko si je igralec golfa Tiger Woods uničil »brand « z enim samim neprimernim dejanjem. Po drugi strani imamo fenomen Volkswagen, ki si »branda organizacije« ni uničil niti z nepravilnostmi vozil pri merjenju porabe goriva. 
94 PosLOVNO KOMUNICIRANJE 
PosLOVNO KOMUNICIRANJE

M. Ferjan

\section{KOMUNICIRANJE PERCEPCIJSKIH ORGANIZACIJ}



Namen, vsebine, uporabljeni kanali, dinamika in usmerjenost komuniciranja percepcijskih organizacij izhaja iz:

- poslanstva organizacije in

- namena obstoja organizacije.

Nastanek in obstoj organizacij praviloma ni samemu sebi namen. Vsaka organizacija ima opredeljeno poslanstvo. Opredelitev poslanstva organizacije mora odgovoriti na vprašanja:

- Kaj je dejavnost organizacije?

- Komu je dejavnost namenjena?

- Kdo so partnerji organizacije?

- Kaj cenijo partnerji in kaj se ceni nasploh?

- Kaj je kriterij uspeha?

Organizacija za svoje delovanje potrebuje vire. Vire za svoje delovanje s svojim delovanjem ustvarja sama, lahko pa jih zagotavljajo lastniki ali ustanovitelji. Količina lastnih virov nikjer ni neomejena. Zato je vsaka organizacija zavezana optimalnemu ravnanju. Bistvo managementa organizacije je prav $\mathrm{v}$ tem, da management mora zagotoviti optimalno delovanje organizacije, tudi iz vidika porabe virov. Omejenost količine virov predstavlja ključni omejitveni dejavnik pri zagotavljanju zadovoljstva kupcev in pri izpolnjevanju pričakovanj okolja. Ni vedno nujno, da je vsa pričakovanja okolja v okvirih realnih danosti sploh mogoče uresničiti. Napačno je pojmovanje, da si organizcija lahko zagotovi neomejeno količino virov. Prav tako je napačno mišljenje, da neomejeno količino virov mora $\mathrm{v}$ nedogled zagotavljati lastnik ali ustanovitelj. Organizacija vsaj na daljši časovni rok mora v bilanci uspeha izkazovati pozitivni poslovni izid, denarni tok organizacije pa na daljši časovni rok ne sme biti negativen.

Kot smo že omenili, so predstavniki ekonomske doktrine neoliberalizma zagovarjali stališče, da je namen obstoja podjetja ustvarjati dobiček.

Tako ozko pojmovanje namena obstoja podjetij v današnji družbi ne vzdrži več. Vsaka organizacija poleg svojih lastnih virov namreč porablja tudi različne vire iz okolja. Za svoj obstoj potrebuje prostor. Porablja vodo, surovine in energete. Zaposluje ljudi iz okolja. Nenazadnje so tu tudi odpadki, katere je treba nekje odložiti. Že zaradi naravnih danosti je količina virov iz okolja omejena. Subjekti iz okolja imajo torej vso pravico, da od organizacij pričakujejo, da tudi s temi viri ravna optimalno.

Sodobnejše pojmovanje namena obstoja podjetij prikazuje model EFQM. Kot ključni namen obstoja organizacije sicer prav tako postavlja rezultate poslovanja. 
EFQM pravi da: »Odlične organizacije dosegajo in trajno ohranjajo izjemne rezultate, $k i$ zadovoljujejo ali presegajo potrebe in pričakovanja njihovih poslovnih deležnikov.«

Rezultat poslovanja organizacij po definiciji modela EFQM je posledica:

- Rezultatov, povezanih z odjemalci: odlične organizacije dosegajo in trajno ohranjajo izjemne rezultate, ki zadovoljujejo ali presegajo potrebe in pričakovanja svojih odjemalcev.

- Rezultatov, povezanih z zaposlenimi: odlične organizacije dosegajo in trajno ohranjajo izjemne rezultate, ki zadovoljujejo ali presegajo potrebe in pričakovanja njihovih zaposlenih.

- Rezultatov povezani $z$ družbo: odlične organizacije dosegajo in trajno ohranjajo izjemne rezultate, ki zadovoljujejo ali presegajo potrebe in pričakovanja relevantnih deležnikov v družbi.

Za udejanjanje poslanstva in izvrševanje namena obstoja katerekoli organizacije so potrebne neprestane interakcije organizacije $\mathrm{z}$ okoljem.

Organizacije, ki pa so po dejavnosti poslovni subjekti, imajo interakcije z okoljem, ki imajo naravo poslovnih funkcij:

- organizacija v okolju nabavlja izdelke ali storitve;

- med organizacijo in ljudmi iz okolja se sklepajo pogodbe o zaposlitvi;

- organizacija prodaja izdelke ali storitve oziroma izvaja dejavnost, ki za okolje predstavlja dodano vrednost;

- med organizacijo in subjekti iz okolja poteka plačilni promet.

Pri poslovnih funkcijah imamo opravka z:

- izmenjavo materiala, storitev ali virov;

- denarnim tokom;

- izmenjavo informacij.

Poslovne funkcije torej niso zgolj izmenjava proizvodov ali storitev in denarja, pač pa med udeleženimi subjekti vzporedno poteka tudi izmenjava informacij.

Poslovanje organizacije z okoljem se ne vzpostavi kar samo od sebe. Mathieson (2010) pravi, da je ponudnikov dobrin toliko, kot je dreves v gozdu. Z nekom, ki ga ljudje ne opazijo, ne morejo sodelovati, niti sklepati poslov. Šele, ko subjekti iz okolja organizacijo v množici sploh »opazijo«, se lahko odločajo o sodelovanju.

Peter Corrigan (2008) začenja svojo knjigo z zelo zanimivim vprašanjem: Kako ljudje pravzaprav ravnajo? Njegov odgovor je: Na podlagi tistega, kar zaznavajo. 
Vendar ni vedno tako. Grunning-ova (2012) pravi, da je skoraj vsaka človekova odločitev v življenju sprejeta na podlagi stališč, mnenj in vrednot. Stališča in mnenja so nastala:

- ali na podlagi prejetih informacij;

- ali zaradi pomanjkanja informacij.

Več ko nekdo ve o podjetju, jasnejša bo njegova mentalna slika, ki si jo o njem ustvari. Pogosto nekaj naredimo, potem pa si rečemo »Če bi prej to vedeli, bi ravnali drugače...« Ljudje torej lahko sprejemamo odločitve tudi, ne da bi bili o neki zadevi podrobno informirani.

Komuniciranje organizacije z okoljem je nujno, da organizacija sploh postane »opazna«. Vendar to še ni dovolj. Če imajo ljudje o podjetju poleg tega, da ga opazijo tudi dobro mnenje, je večja verjetnost, da bo podjetje za to nagrajeno:

- Če bo podjetje zagotavljalo zadovoljstvo kupcev, bo podjetje prodajalo svoje izdelke. S tem bodo imeli korist vsi:

○ podjetje, ker je prodalo izdelek in si s tem zagotovilo denarni tok;

○ kupci, ker bodo poleg nakupa ob tem imeli še dober občutek.

- Če bo podjetje imelo dober image, bo imelo več možnosti, da doseže boljše poslovne pogoje pri poslovnih partnerjih.

- Če bo podjetje sčasoma postalo ugledno, bodo imeli korist lastniki, ker se bo vrednost podjetja povečala.

- Če bo podjetje imelo zadovoljne kupce in dober image, bo lažje vplivalo na dejavnike okolja.

Komniciranje organizacij z okoljem ni nekaj novega. Organizacije so že desetletja planirale, organizirale in prek različnih kanalov izvajale ter tudi vrednotile komuniciranje z okoljem. S tem imamo seveda v mislih želeno komuniciranje organizacij.

Po klasičnem pojmovanju so organizacije razločevale:

- komuniciranje s ciljnimi skupinami in

- odnose z javnostmi.

Ciljne skupine so dejanski ali potencialni kupci. Komuniciranje s ciljnimi skupinami imenujemo marketinško komuniciranje.

Javnosti pa so skupine ljudi, ki dejansko ali potencialno lahko vplivajo na poslovanje organizacije.

V času brez interneta so strokovnjaki za marketing dokaj enostavno opredelili atribute ciljnih skupin, strokovnjaki za odnose z javnostmi pa javnosti organizacije.

Marsikdo, zlasti iz nekaterih sfer »civilne družbe« organizacijam oporeka interakcije z okoljem v zvezi s postavljanjem norm okolja. Oporekanje se nanaša še posebej na 
lobiranje. Vendar lobiranje obstaja že stoletja. Strinjamo se, da koruptivno lobiranje ne more soditi v sodobno družbo. Ker pa ima okolje do organizacij veliko pričakovanj, je logično, da mora obstajati recipročnost. Postavljanje in spoštovanje pravnih, tehničnih in poslovnih norm okolja vezano na trenutno stopnjo razvoja tehnologije in na druge objektivne danosti. Norme, želje in pričakovanja okolja smejo biti taka, da stopnja razvoja tehnologije in druge danosti organizacijam omogočajo uresničitev. Okolje organizacijam zato mora dati tudi možnost, da na transparenten način predstavijo svoja stališča. V nasprotnem se kaj lahko zgodi, da norme postanejo neuresničljive. Dvosmeren proces interakcij med organizacijo in okoljem lahko deluje zgolj $\mathrm{v}$ okoljih, kjer se tako $\mathrm{v}$ organizacijah kot $\mathrm{v}$ okolju spoštujejo minimalni standardi etičnosti ravnanja. Tudi v odnosu etičnosti ravnanja mora obstajati recipročnost. Primer je lahko odnos med podjetjem in sindikatom:

- Podjetje ne more pričakovati zavzetosti zaposlenih, hkrati pa kršiti pravice delavcev in v pogajanjih s sindikati nastopati iz pozicije moči.

- Sindikat ne more pričakovati posebnih bonitet za zaposlene, hkrati pa na najrazličnejše načine ščititi najbolj problematične zaposlene ali postavljati organizaciji nezakonite zahteve.

Po izumu in množični uporabi interneta so se stvari bistveno spremenile. Internet ni zgolj nov medij za razširjanje sporočil. S pojavom interneta je prišlo tudi do drugih sprememb. Te spremembe so do neke mere sicer lahko primerljive s spremembami sredi 19. stoletja, ko se je razvil množični tisk in se je začela razvijati prometna infrastruktrura. Spremembe, ki jih prinaša internet, so mnogo obsežnejše od takratnih. Internet je povzročil:

- večjo hitrost razširjanja sporočil;

- večjo možnost dostopa do najrazličnejših sporočil za zelo velik del populacije;

- zmanjšanje nadzora nad objavljenimi sporočili;

- možnost sprejemanja mnogo večje količine sporočil;

- možnost objavljanja lastnih sporočil.

Internet spreminja tudi kulturo družbe:

- Številna sporočila na internetu ljudem omogočajo, da se lažje izogibajo negotovosti zaradi pomanjkanja informacij.

- Spreminja se odnos do moči in avtoritet.

- Vsaj v določenih delih skupnosti se pojavljajo vprašanja, vezana na človečnost.

Posledično je $\mathrm{v}$ zadnjih desetletjih prišlo do sprememb v razumevanju namena obstoja podjetij.

Chaney (2009) pravi, da je današnje obnašanje potrošnikov videti kot »upor«. Klasičnih oglasov že dolgo nihče več niti ne opazi. Ljudje tudi medijem ne verjamejo več. Pravi, da je bilo leta 2009 kar 80\% nakupov v ZDA opravljenih na podlagi zaupanja v izdelek. Ljudje iščejo informacije prek zaupanja vrednih osebnih virov. 
Mnogi avtorji čudežne rešitve vidijo $\mathrm{v}$ konceptu digitalnega marketinga in spletnih odnosov z javnostmi. Chaney (2009) ponuja tudi rešitve. Podjetja morajo po njegovem:

- $\quad$ "prešteti« tiste, ki grdo govorijo o njih in njihovih izdelkih;

- nagraditi tiste, ki imajo o njih dobro mnenje;

- začeti uporabljati iste medije, kot jih uporabljajo njihove stranke.

Te rešitve so sicer pomembne, saj se kanali komuniciranja organizacij z okoljem nedvomno spreminjajo in temu morajo slediti tudi ponudniki dobrin. Organizacije pri komuniciranju nedvomno prehajajo od klasičnih medijev na internet. Vendar niti digitalni marketing, niti spletni odnosi z javnostmi sama po sebi nista čudežni rešitvi za 21. stoletje.

Izum interneta namreč ni povzročil samo tega, da so na voljo povsem novi kanali komuniciranja organizacij z okoljem. Popolnoma se je spremenil tudi način obnašanja ljudi. Nastala je potreba po spremembi filozofije delovanja organizacij in s tem tudi potreba po spremembi filozofije komuniciranja organizacij z okoljem.

Tako ostrega ločevanja med pojavnimi oblikami komuniciranja ter med ciljnimi skupinami in javnostmi, kot je bilo to v preteklosti, s pojavom interneta ne more biti več.

Ciljne skupine kot ljudi, ki so dejanski ali potencialni kupci je bilo v dobi brez interneta možno dokaj enostavno demografsko in geografsko locirati. S pojavom interneta organizacije nastopajo na globalnem trgu. Konkurenca v dobi interneta je globalna, saj ima kupec možnost kupiti nek izdelek prek spleta kjerkoli na svetu.

Spremenil se je tudi način nakupovanja in prodajanja izdelkov ter celo financiranja. V dobi brez interneta je sicer kupec lahko izbiral med različnimi načini nakupa: $v$ trgovini, prek osebne prodaje, prek kataloga ali prek prodajnega zastopnika. Internet pa je nekaj novega. Vsebina lahko hkrati predstavlja: oglas, katalog, prodajnega zastopnika, trgovino in celo projektni biro, saj si kupec lahko celo sam konfigurira izdelek.

Klasični odnosi z javnostmi so znali dokaj dobro opredeliti javnosti organizacije, vsebine zanimanja javnosti, ter stopnje aktivnosti posameznih javnosti. Internet odpira možnost nastanka socialnih skupnosti in s tem povezanih kolektivnih kognicij ali kognitivne disonace. Lahko se zgodi, da javnost katerekoli organizacije prihaja iz kateregakoli dela sveta. Člani neke javnosti imajo tehnične možnosti medsebojnega komuniciranja v kateremkoli trenutku. Pojmovanje javnosti se je zato spremenilo. Če je bil še pred leti kriterij za prepoznavo javnosti problem, ki ga organizacija povzroča ljudem v svojem neposrednem okolju, je to lahko danes nekaj drugega. Spremenile so se tudi vsebine zanimanja ljudi. Današnje javnosti povezujejo vsebine zanimanja, ki jih včasih sploh ni bilo. V ospredje prihajajo vsebine, vezane na globalne okoljevarstvene probleme, na družbeno odgovorno in socialno pravično ravnanje ter trajnostni razvoj.

Internet je tudi vir informacij o poslovanju organizacij. To terja drugačno filozofijo pristopov organizacij k pogajanjem. Bolj kot kadarkoli doslej so pomembne priprave na pogajanja. Zaradi večje informiranosti pogajalskih strani je praktično nemogoča uporaba 
nekaterih dosedanjih pogajalskih taktik, predvsem takih, ki so bile nekoč običajna praksa, danes pa jih štejemo za neetične.

Pred pojavom interneta je bila možnost razširjenja za organizacijo neželenih informacij mnogo manjša. Za neželeno razširjanje informacij je bil potreben vir, znanje in obstoj medija oziroma novinarja, ki je bil pripravljen to objaviti. To danes ni več noben problem. $\mathrm{Na}$ internetu je možno takoj objaviti vse. Internet predstavlja vsakomur dostopen kanal za razširjanje sporočil o nesrečah, škandalih in napakah na proizvodih. Za razširjanje sporočil ni več potreben obstoj medija oziroma novinarja. Sporočila se lahko razširjajo prek forumov, blogov in raznih spletnih portalov, katere lahko kreira kdorkoli. Objavljena sporočila so lahko resnična ali pa tudi neresnična. Organizacije so s tem postale soočene z novim izzivom kriznega komuniciranja.

Organizacije so v preteklosti lahko fizično omejile dostop do svojih notranjih informacij., danes pa postajajo vdori v informacijske sisteme vsakodnevni pojavi.

Kljub vsemu, kar prinaša virtualna realnost interneta, realni svet ni izumrl, se je pa zelo spremenil. Komuniciranja ni več mogoče obravnavati kot enosmerni proces. Še nedavno so organizacije s pristopi marketinškega komuniciranja obvladovale behaviorizem potrošnikov. $\mathrm{Z}$ uporabo modelov odnosov $\mathrm{z}$ javnostmi je bilo mnogo bolj kot danes mogoče oblikovati javno mnenje in tudi vplivati na image in ugled organizacij. Danes je komuniciranje bolj kot kadarkoli v zgodovini postalo dvosmerno. Funkcij komuniciranja, kot so: marketinško komuniciranje, odnosi z javnostmi, pogajanja, lobiranje, krizno komuniciranje ni več mogoče obravnavati medsebojno ločeno. Komuniciranje organizacije se mora izvajati integralno. Zaradi spremenjenih zahtev časa pa je funkcijo komuniciranja mogoče šteti kot novo poslovno funkcijo organizacije.

\section{Naloga funkcije komuniciranja je, da ob upoštevanju namena obstoja organizacije in norm okolja zagotovi kontinuirano in uravnoteženo interakcijo med organizacijo in okoljem $\mathrm{z}$ namenom medsebojne uskladitve.}

Pojavne oblike komuniciranja organizacije z okoljem so:

- interpersonalno komuniciranje managementa in zaposlenih z okoljem;

- komuniciranje organizacije preko spletnih kanalov;

- marketinško komuniciranje;

- odnosi z javnostmi;

- odnosi z vlagatelji;

- pogajanja;

- lobiranje;

- krizno komuniciranje.

Naštetih pojavnih oblik ni več mogoče obravnavati parcialno, tako kot v preteklosti. Treba jih je obravnavati kot enoten proces dvosmernega komuniciranja organizacije $\mathrm{z}$ okoljem. 
Cilj komuniciranja organizacije z okoljem je usklajevanje ter uskladitev organizacije in okolja.

Objekt, na katerega se komuniciranje organizacije nanaša, je identiteta organizacije.

Vsebina komuniciranja se nanaša:

- $\mathbf{z}$ vidika organizacije: na vse atribute identitete organizacije.

- z vidika okolja: na norme, potrebe, pričakovanja in želje do organizacije.

Proces komuniciranja organizacije je dvosmeren, kar pomeni, da je naloga komuniciranja:

- pošiljanje sporočil o identiteti organizacije $\mathrm{v}$ okolje;

- sprejemanje sporočil o normah, omejitvah, potrebah, pričakovanjih in željah iz okolja;

- usklajevanje atributov identitete organizacije in norm, pričakovanj, potreb in želja okolja v okvirih namena obstoja organizacije in omejitev okolja.

Komuniciranje organizacije $\mathrm{z}$ okoljem poteka:

- pred dogodki, ki so pomembni tako za organizacijo kot za okolje;

- med potekom dogodkov, ki so pomembni za organizacijo in za okolje;

- po dogodkih, ki so pomembni za organizacijo in za okolje.

Pogoja za to, da lahko pride do uskladitve sta:

- da okolje organizacijo prepozna in razume njeno poslanstvo, namen njenega obstoja ter omejitve;

- da organizacija razume norme, omejitve, potrebe, želje in pričakovanja okolja. 
Komuniciranje percepcijskih organizacij 
PoSLOVNO KOMUNICIRANJE

M. Ferjan

\section{ZAPOSLENI IN MANAGEMENT}



Vsaka organizacija je v najbolj neposrednem stiku z okoljem preko svojih zaposlenih. Oblike komuniciranja organizacije z okoljem, kot so: atributi izdelkov, njihova oblika in barva, embalaža, cena, navodila za uporabo, spletno komuniciranje, video vsebine, članki v časopisih, vse oblike oglaševanja, spletne strani, elektronska pošta in podobno, so zgolj del nežive narave. Človek pa je del žive narave.

Zaposleni so v interakcijah z okoljem med svojim delovnim časom. Vsebine interakcij se ne nanašajo na njih kot zasebnike. Tako po razlogu kot po vsebini so $\mathrm{v}$ povezavi $\mathrm{z}$ organizacijo. Brez neprestanih interakcij zaposlenih z okoljem, organizacija sploh ne bi mogla poslovati. Če ne bi prek svojih zaposlenih izvajala svojih poslovnih funkcij, tudi ne bi mogla doseči namena svojega obstoja. Zaposleni ne bi mogli prejeti plač.

Če bi sešteli vse medosebne interakcije, bi ugotovili, da je teh mnogo več, kot katerekoli druge oblike komuniciranja organizacije z okoljem. Zaznave zaposlenih ljudje iz okolja percepirajo. Ker so te zaznave vsakodnevne, pride do kognicij, do kolektivnih kognicij in na koncu do pojava socialnih shem.

Ljudje iz okolja zaznave zaposlenih povezujejo $\mathrm{z}$ organizacijo. Zato je prav vsak zaposleni del identitete organizacije.

V zadnjih desetletjih so bile opravljene številne raziskave o tem, kakšen je mehanizem interakcije med organizacijo, zaposlenimi in strankami. Vsebine raziskav so šle v različne smeri.

Nekateri raziskovalci (npr.: Heskett in soavtorji, 1997) so menili, da na zadovoljstvo strank vplivajo vrednote zaposlenih. Zato je po mnenju Heskett-a in soavtorjev (1997) ključno to, da podjetja zaposlujejo ljudi, ki imajo ustrezne vrednote.

Približno v istem času so bile opravljene raziskave, ki so raziskovale, ali je zadovoljstvo zaposlenih v organizaciji tisto, ki vpliva tudi na zadovoljstvo strank. Eno temeljnih del na tem področju je leta 2001 objavil Daniel Koys. Dve leti je preučeval obnašanje zaposlenih v 28 restavracijah. Ob izhodu iz restvracij je bilo vzporedno s tem anketiranih 9.903 gostov, katerim je bilo postavljenih 24 vprašanj glede zadovoljstva. Zanimalo ga je:

- ali obnašanje zaposlenih vpliva na profitabilnost podjetja in

- kako zadovoljstvo zaposlenih vpliva na zadovoljstvo strank.

Ugotovljeno je bilo:

- Zadovoljstvo strank in profitabilnost podjetja sta spremenljivki, ki sta odvisni od različnih dejavnikov.

- Obnašanje zaposlenih nedvomno vpliva na profitabilnost podjetja. 
- Zadovoljstvo zaposlenih in zadovoljstvo strank sta medsebojno (recipročno) odvisni.

- Zadovoljstvo zaposlenih in profitabilnost podjetja sta med seboj neodvisni spremenljivki.

- Vrednote zaposlenih niso direktno povezane z zadovoljstvom strank.

Evanschitzky in soavtorji (2011) so v ZDA opravili raziskavo na vzorcu 150 franšiznih prodajalen. Tudi njih je zanimalo, kateri so dejavniki, ki vplivajo na zadovoljstvo strank. Ugotovili so:

- Največji vpliv na zadovoljstvo strank ima prodajni asortiman.

- Velik in statistično pomemben vpliv na zadovoljstvo strank ima osebje prodajalne.

- Cena produktov na zadovoljstvo strank sploh ni imela nobenega vpliva.

- Odnos lastnika franšizne prodajalne na zadovoljstvo strank vpliva zgolj posredno.

Do skoraj identičnih zaključkov je prišel Prokopis (2009) na primeru supermarketov v Grčiji. Ugotovil pa je da različni tipi kupcev osebju pripisujejo različen pomen.

Tor Wallin Andreassen in Bodil Lindestad sta leta 1998 opravila nekoliko drugačno raziskavo. Anketirala sta 600 uporabnikov paketnih potovanj. Zanimalo ju je, kakšen je odnos med kategorijami:

- image podjetja;

- zadovoljstvo strank in

- lojalnost strank.

Ugotovila sta:

- Image podjetja in zadovoljstvo strank sta dve različni kategoriji.

- Image podjetja neposredno vpliva na lojalnost kupcev, zadovoljstvo strank pa na lojalnost ne vpliva neposredno, pač pa zgolj posredno.

Kasneje so bile v različnih delih sveta opravljene podobne raziskave, s katerimi je bilo potrjeno, da image podjetja neposredno vpliva na lojalnost strank.

Del image-a podjetja so seveda tudi zaposleni. Zlasti v zadnjem desetletju so bile opravljene mnoge raziskave, ki so to potrdile. Tako so npr.: tudi Minkiewicz in soavtorji (2011) s svojo raziskavo to potrdili, Pomembni atributi osebja so: »kompetence«, »ustrežljivost« in »socialnost«. Kakovost izdelkov ali storitev različnih ponudnikov po njihovem mnogi ljudje štejejo kot »splošno dejstvo«, ki ne bi smelo biti nikjer vprašljivo.

V tej knjigi smo že opisali, da človek zaznava VSE simbole kot CELOTO. Kako pomembni za človekove odločitve so VSI zaznani simboli, je utemeljeno z že opisanimi 
ugotovitvami nevroznanosti. Eden najvidnejših psihologov Antonio Damasio ${ }^{19}$ pravi, da živčni terminali povežejo zaznane signale iz čutil preko živčevja $v$ možgane po tako imenovanem senzoričnem korteksu. Zaznave kot primarni učinek v možganih povzročijo percepcijo in čustva. Na osnovi prve zaznave pride tudi do intuicije. Intuicija je hitro spoznavanje na osnovi zaznave in na podlagi preteklih izkušenj brez vključevanja čustev. Prva zaznava je torej pomembna tudi za intuicijo.

Pogosto se izpostavljajo vizualni simboli, predvsem obleka. Res je, da je vizualna zaznava prva. Vendar ljudje ne zaznavamo zgolj vizualne podobe. Pomembni so VSI simboli o organizaciji, ki jih ljudje iz okolja zaznavajo od zaposlenih.

Kot smo že opisali, Elsbach (2013) meni, da je image organizacije sestavljen iz več dimenzij. Med njimi sta tudi zanesljivost in pravilnost.

Zanesljivost, ki je lastnost organizacije, da pri svojem delovanju izkazuje kompetence, dobrohotnost in integriteto, ljudje iz okolja zaznajo iz:

- kompetenc in

- zavzetosti zaposlenih.

Za delovanje organizacije navzven je zelo pomembna tudi notranja kohezivnost. Notranjo neenotnost med člani organizacije okolje lahko zazna.

Ljudje iz okolja zaznavajo tudi pravilnost in doslednost. Pri zaznavanju pravilnosti in doslednosti so osredotočeni na delovanje managementa.

${ }^{19}$ Povzeto po: (Corrigan, 2008). 
Zaposleni in management 


\section{POSLOVNO OBLAČENJE}

\section{Pomen vizualne zaznave}

Okolju in okoliščinam ustrezna izbira oblačil je v zgodovini človeštva lahko pomenila preživetje, napačna pa celo smrt. Oblačenje je razvil človek, da bi si v različnih okoliščinah in okoljih omogočil svoj obstoj. Pred tisočletji so se ljudje oblačili v živalske kože, da bi tudi v mrazu preživeli. Vitezi srednjega veka so bili oblečeni v oklepe, da bi se zaščitili. Vojaki na fronti so oblečeni v maskirne obleke. Človek, ki je hodil po Luni, je moral biti za to primerno oblečen in obut.

Primerna poslovna obleka v današnjem času odloči med pridobitvijo ali zavrnitvijo posla. McKnight (2013) celo pravi, da image predstavlja »mejo med življenjem in smrtjo«. Mnogi temu še vedno ne verjamejo, ali se sprašujejo, zakaj je temu tako.

Človeštvo je pomen oblačil sprejelo. Ustvarilo je uniforme, kodekse in socialne sheme. Socialne sheme o oblačenju so zgodovinsko dejstvo. Obstajajo že tisočletja.

Obleka je objekt zaznave sočloveka. Prva pojavna oblika zaznavanja sočloveka je prav vizualna zaznava. Na osnovi zaznave pride do percepcije. Ko na vlaku potniki s čutili zaznajo pojavo sprevodnika, pri njih takoj pride do percepcije, da je to sprevodnik. Na osnovi zaznave in percepcije ter preteklih izkušenj pride do refleksa in ravnanja. Potniki pripravijo vozovnice.

Ključna okoliščina prve zaznave in percepcije človeka je, da obleka spremeni vizualno podobo telesa. Obleka lahko moškega vizualno spremeni v žensko. Telo istega človeka lahko vizualno spremeni v kralja, vojaka, duhovnika, ... Ni si mogoče predstavljati, da bi osebo, oblečeno v uniformo sprevodnika, ljudje percepirali kot manekenko.

Sistemi, kot so vojska, policija pravosodje, letalske družbe, zdravstvo in drugi so prav zato že zelo zgodaj začeli uporaljati okolju in okoliščinam prilagojene uniforme. Pomen uniform ni bil zgolj v zaščiti telesa pred zunajimi vplivi.

Kdor nosi uniformo, sprejme svoj položaj. Prisili tudi drugega, da ta položaj sprejme. Če ljudje iz okolice človeka ne zaznajo v neki vlogi, ga v tej vlogi tudi ne morejo percepirati. Telo človeka, oblečenega v klovna, študenti ne morejo percepirati kot profesorja. Policist se brez kape in vseh sestavin policijske uniforme niti sam ne bo počutil kot policist. Tudi okolica ga ne bo prepoznala v vlogi policista.

S tem, ko nekdo obleče oblačila za neko priložnost oziroma za neko vlogo, sporoča, da se je vloge zavedal že prej in se je s primernim oblačenjem na vlogo pripravil. Sporoča tudi da vlogo sprejema. Človek z obleko kaže svoj odnos do vloge, do ljudi, s katerimi je skupaj v tej vlogi in do ljudi, ki ga v tej vlogi opazujejo. 
Tako kot uniforme, ima tudi poslovno oblačenje psihološke učinke. Človekova obleka za zasebnost in prosti čas je drugačna, kot v službi oziroma ob posebnih priložnostih.

Obstajajo zapisana in nezapisana pravila poslovnega oblačenja. Kot pravijo sociologi (npr.: Corrigan, 2008) je obleka skozi zgodovino ljudi razločevala glede na:

- spol;

- družbeni razred;

- moč;

- poklic;

- veroizpoved,

- drugo.

Kot pravi Wilkin (2016) so že v bronasti dobi ornamenti, velikosti ščitov in dodatki zlata imeli socialni in obredni pomen. Hoss (2016) pravi, da je bil usnjen vojaški pas (imenovan »balteus«) zapet $\mathrm{z}$ zaponko in okrašen s kovinskimi nosilci kot del vojaške opreme rimskega vojaka pomemben statusni simbol. Vojaški pasovi, so bili potem še do zgodnjega srednjega veka znani kot ikona kosov takratne vojaške obleke. Pomen pasu kot zelo pomembnega dela moške garderobe ima torej svoj zgodovinski izvor. Hoss (2016) nadalje pravi, da je bila v starem Rimu ključna vrednota kodeksa oblačenja material, iz katerega je bila obleka izdelana.

Knox (2016) pravi, da nekateri dokazi kažejo, da bi po končanem pokristjanjevanju v 9. stoletju v severozahodni Evropi ljudje že utegnili imeti tudi oblačila za posebne priložnosti (npr. za pogreb).

Awais-Dean (2016) pravi, da so se prvi bolj natančni opisi oblek pojavili v 16. stoletju.

Obleka je v zgodovini očitno imela svojo funkcijo. Predstavljala je pomemben del identitete narodov, religij, družbenih gibanj, organizacij, poklicev in nenazadnje tudi posameznikov. Spomnimo se samo nekaterih:

- Mahatma Gandhi v svoji značilni obleki;

- Fidel Castro v vojaški uniformi in z dvema urama Rolex;

- kraljica Elizabeta II. v značilni obleki in s klobučkom.

Letnemu času in zunanji temperaturi primerna obleke predstavlja neke vrste »aklimatizacijo«. Obleka in videz posameznika v različnih poklicnih in družbenih vlogah pa kaže človekovo sposobnost kulturne, poklicne in socialne »aklimatizacije«. Kultura oblačenja zaposlenih je del identitete vsake organizacije.

\section{Vpliv videza na ugled}

Obleka ni pomembna zgolj za percepcijo človeke vloge v organizaciji in v družbi. Vpliva tudi na njegov ugled. 
Anketirali smo 341 zaposlenih oseb, od tega 147 (42,4\%) moških in 194 (56,9\%) žensk.

Povprečna starost vprašanih je bila 32 let. Postavili smo hipotezo, da med videzom vodje in ugledom, ki ga vodja uživa pri podrejenih, obstaja odvisnost.

Odvisno spremenljivka (v prikazu rezultatov z oznako “A”), ki je bila »ugled vodje« smo merili tako, da smo anketirancem postavili vprašanje: »Prosimo, ocenite, kakšen ugled uživa vaš neposredni vodja oddelka med svojimi sodelavci!« Ponudili smo jim naslednje možne odgovore:

1 - vodja v večini ne uživa prav nobenega ugleda;

2 - vodja uživa ugled samo med posamezniki;

3 - ugled vodje ocenjujem z oceno »srednje;

4 - med večino je vodja kar ugleden;

5 - moj vodja velja za zelo uglednega.

Kot neodvisne spremenljivke (v prikazu rezultatov z oznakami od "B" do "J"), smo postavili naslednje dimenzije videza:

B. čistoča, urejenost obutve;

C. čistoča, urejenost obleke;

D. nega obraza;

E. urejenost pričeske;

F. vonj;

G. ura, nakit;

H. avto;

I. urejenost pisarne;

J. oprema pisarne.

Anketirancem smo postavili vprašanje: »Prosimo v ocenite, kolikšno pozornost vaš šef (šefica) oddelka namenja naštetim elementom videza!« Ponudili smo jim naslednje možne odgovore.

1 - ne posveča prav nobene pozornosti, vseeno mu je, niti ne razmišlja o tem, da je to pomembno;

2 - zaveda se, da to obstaja;

3 - ob posebnih priložnostih temu posveti pozornost, sicer pa ne;

4 - navadno temu posveti precej pozornosti;

5 - temu vedno posveti prav posebej veliko pozornost.

Korelacijska analiza med dimenzijami videza in »ugledom vodje« je prikazana v tabeli 1. 


\section{Tabela 1: Korelacijska analiza med dimenzijami videza in »ugledom vodje«}

\begin{tabular}{|c|c|c|c|c|c|c|c|c|}
\hline A & B & C & D & $\mathbf{E}$ & $\mathbf{F}$ & G & $\mathbf{H}$ & I \\
\hline, $376^{* *}$ & & & & & & & & \\
\hline, $358 * *$ &, $856^{* *}$ & & & & & & & \\
\hline, $349 * *$ &, $668 * *$ &, $641 * *$ & & & & & & \\
\hline, $360 * *$ &, $573 * *$ &, $578 * *$ &, $709^{* *}$ & & & & & \\
\hline, $364 * *$ &, $583 * *$ &, $608 * *$ &, $584 * *$ &, $657 * *$ & & & & \\
\hline, $274 * *$ &, $466^{* *}$ &, $437 * *$ &, $452^{* *}$ &, $488 * *$ &, $429 * *$ & & & \\
\hline, $124^{*}$ &, $227 * *$ &, $162 * *$ &, $251 * *$ &, $228 * *$ &, $192 * *$ &, $389 * *$ & & \\
\hline, $249 * *$ &, $357 * *$ &, $336^{* *}$ &, $292 * *$ &, $325 * *$ &, $327 * *$ &, $262 * *$ & ,216** & \\
\hline, $168 * *$ &, $312 * *$ &, $282 * *$ &, $277 * *$ &, $214 * *$ &, $268 * *$ &, $200 * *$ &, $264 * *$ &, $650 * *$ \\
\hline
\end{tabular}

Očitno je, da med vsemi dimenzijami videza in »ugledom vodje« obstajajo statistično pomembne korelacije. Da bi ugotovili, kakšen skupni vpliv imajo te spremenljivke na ugled vodje, smo opravili še faktorsko analizo. Najprej smo izračunali Cronbach-ov koeficient Alpha. Njegova vrednost znaša 0,86 kar kaže na veliko zanesljivost merjenja.

Najprej smo opravili faktorsko analizo. Dobili smo dva nova faktorja. Oba sta statistično pomembna. Nato pa smo opravili še regresijsko analizo. Odvisna spremenljivka je bila »ugled vodje«.

Ugotovili smo, da s spremenljivkami iz skupine »dimenzije videza« lahko pojasnimo $\mathbf{1 8 , 1 \%}$ variance spremenljivke »ugled vodje«. Spremenljivke, ki sestavljajo »faktor 1 « so pomembnejše. Te so: osebni videz, čistoča, urejenost obleke, urejenost pričeske, urejenost obutve, nega obraza, vonj, ura in nakit. Manjši vpliv pa imajo spremenljivke, vključene v novi faktor 2 . Te so: urejenost in oprema pisarne ter avto.

\section{Pravila poslovnega oblačenja}

Univerzalno pravilo poslovnega oblačenja je, da se oblečemo okolju in okoliščinam primerno. Tako, kot za različne temperature oblačimo različne obleke, je tudi za različne okoliščine in priložnosti pričakovano, da v oblačenju ni neskladij. Če v hudem mrazu oblečemo pulover in jesensko jakno, nas bo sicer zeblo, vendar bomo nekako preživeli. Ne moremo pa pozimi, ko so temperature nizke, obleči kratkih hlač. Podobno velja za poslovno oblačenje. Neskladja za en »nivo« sloga so dopustna in niso v zelo velikem nasprotju s pričakovanji. Neskladja $\mathrm{v}$ oblačenju za več kot en nivo sloga pa pomenijo enako, kot če bi v poletni vročini oblekli zimsko bundo.

Pravila (kodeksi) oblačenja so zapisana in nezapisana pravila ter pričakovanja glede oblačenja in fizičnega videza. Odvisna so od: podnebnega okolja, poklicne oziroma družbene vloge posameznika ter od drugih okoliščin, priložnosti in pričakovanj. 
Skozi zgodovino so se razvila pravila oblačenja predvsem za različne poslovne priložnosti in družabne dogodke. V grobem jih lahko razvrstimo na:

- uniforme sistemov;

- pravila oblačenja za svečane (gala) večerne dogodke;

- pravila poslovnega oblačenja.

Obleka za svečane (gala) večerne dogodke pa je lahko:

- popolna večerna obleka (»white tie «);

- večerna obleka (»black tie «)

Zahteve glede poslovne obleke managerjev so strožje od običajne poslovne obleke zaposlenih.

Poznamo pa tudi slog poslovnega oblačenja, imenovan »casual «. Beseda »casual« ima v slovarjih različne pomene:

- $\quad$ sproščen« in »brezskrben«; ${ }^{20}$

- $\quad » n e f o r m a l e n \ll$ in »neprimeren za posebne priložnosti«; ${ }^{21}$

- " „sproščen«, »neformalen«, »prijeten za nošenje«. ${ }^{22}$

Pomen besede »casual« je zelo ohlapen, torej so tudi pravila zelo ohlapna. Pojmovanja sloga »casual« so zelo različna:

- "Osnovni casual» pomeni, da je nekdo oblečen sproščeno, brezkrbno, neformalno.

- \Smart casual « pomeni »čedno neformalno obleko«. Ne pomeni pa, da je nekdo oblečen »pametno« ali »inteligentno«.

- »Poslovni casual« pomeni sproščeno, neformalno, vendar čedno obleko za v službo.

V nadaljevanju so predstavljene okoliščine, za katere so primerni posamezni slogi oblačenja.

\footnotetext{
${ }^{20}$ https://en.oxforddictionaries.com

${ }^{21}$ http://dictionary.cambridge.org

${ }^{22}$ http://www.macmillandictionary.com
} 
Prosti čas

Osnovni casual

Casual

Poslovni casual

Običajna poslovna obleka

Poslovna obleka managerjev

Gala večerna obleka (Black tie)

Popolna gala večerna obleka

("White tie»)
Izključno za prosti čas.

Ni primeren za:

- delo s strankami, partnerji;

- formalne sestanke;

- formalne dogodke.

Je primeren za:

- opravila brez strank, poslovnih partnerjev;

- dneve, ko ni sestankov;

- posebne oblike dela, ki to zahtevajo.

Je primeren izven delovnega časa.

Je primeren za:

- »casual petke«;

- neformalne sestanke s poslovnimi partnerji;

- neformalne službene dogodke;

- izobraževanja;

- srečanja izven delovnega časa.

Poslovna obleka je obvezna za srečanja s strankami, in partnerji ter za formalne sestanke.

Poslovna obleka mangerjev sestvalja simboliko managementa.

»Black tie» je obvezna za gala dogodke.

»White tie« je obvezna za posebne gala dogodke.

Posamezni slogi oblačenja imajo zelo različne atribute. 


\section{SLOG »PROSTI ČAS«}

V slogu »prosti čas« imamo popolno svobodo oblačenja, zato je dovoljeno oblačiti:

- superge, sandale, odprte čevlje;

- srajco s kratkimi rokavi (če je komu to všeč lahko tudi s kravato);

- bele nogavice;

- jeans (lahko tudi obrabljen ali raztrgan);

- kratke hlače, bermuda hlače;

- majice z raznimi napisi klubov;

- jakne z napisi.

V slogu »prosti čas « je dovoljeno: da nimamo nogavic, da imajo ženske gol trebuh, hrbet in dekolte.

\section{SLOG »CASUAL «}

V slogih »casual« je pričakovano, da se nosi:

- nogavice za obleko;

- usnjene čevlje;

- dolge (temne) hlače;

- „casual“ srajco z dolgimi rokavi.

Sprejemljivo je obleči tudi:

- polo majico s kratkimi rokavi;

- svetle hlače. 
Atributi posameznih slogov »casual« za različne priložnosti pa so:

\begin{tabular}{|c|c|}
\hline Moški & Ženske \\
\hline \multicolumn{2}{|l|}{ Osnovni casual } \\
\hline $\begin{array}{l}\text { T-majica, polo majica, lahko pulover; } \\
\text { elegantne denim hlače, } \\
\text { ekusni športni čevlji (ne superge!). }\end{array}$ & $\begin{array}{l}\text { T-majica, polo majica, lahko pulover; } \\
\text { (denim) hlače ali krilo; } \\
\text { lahko odprti čevlji ali sandali. }\end{array}$ \\
\hline \multicolumn{2}{|l|}{ Smart casual } \\
\hline $\begin{array}{l}\text { srajca z dolgimi rokavi (in pulover) } \\
\text { različnih barv; } \\
\text { polo majice so »sprejemljive«. } \\
\text { hlače iz blaga; } \\
\text { udobni, toda elegantni usnjeni čevlji. }\end{array}$ & $\begin{array}{l}\text { top } \mathrm{z} \text { rokavi ali bluza } \mathrm{z} \text { rokavi; } \\
\text { kombinacija krila ali hlač in jakne iz } \\
\text { blaga; } \\
\text { odprti usnjeni čevlji. }\end{array}$ \\
\hline \multicolumn{2}{|l|}{ Poslovni casual } \\
\hline $\begin{array}{l}\text { barvna ali vzorčasta srajca; } \\
\text { lahkoali ne nujno kravata; } \\
\text { »casual« suknjič ali jakna; } \\
\text { hlače »na rob«; } \\
\text { usnjeni čevlji (lahko brez vezalk); } \\
\text { nogavice. }\end{array}$ & $\begin{array}{l}\text { barvna bluza ali top; } \\
\text { »casual« suknjič ali jakna; } \\
\text { »casual« krilo ali hlače; } \\
\text { zaprti usnjeni čevlji; } \\
\text { nakit. }\end{array}$ \\
\hline
\end{tabular}

Pri poslovnem oblačenju so nekatera oblačila »prepovedana«. Prepovedi veljao tudi za slog »poslovni casual«. »Prepovedana« oblačila so:

- športni copati, sandali, odprti čevlji;

- srajca s kratkimi rokavi kot del poslovnega oblačenja je „prepovedana“; strogo prepovedana je srajca s kratkimi rokavi v kombinaciji s kravato; za v službo ali poslovni sestanek obleči »kavbojke« v kombinaciji s srajco s kratkimi rokavi in še kravato pa je še posebej neprimerno;

- bele nogavice ali večbarvne nogavice;

- manjkajoče nogavice.

- kavbojke;

- kratke hlače ali bermuda hlače;

- majice $\mathrm{z}$ raznimi napisi;

- jakne z napisi;

- ženske obleke, kjer se vidi gol trebuh ali dekolte.

\section{POSLOVNE OBLEKE}

Poslovna obleka sestoji iz:

- primernih čevljev, ki (tako moški kot ženski) morajo biti zaprti;

- temnih nogavic;

- dolgih hlač oziroma krila primerne dolžine;

- srajce z dolgimi rokavi oziroma bluze ali »topa« z rokavi; 
- kravate (za moške);

- suknjiča;

- primerne mehanske ure (za moške);

- nevpadljivega nakita (za ženske).

\begin{tabular}{|c|c|}
\hline Moški & Ženske \\
\hline \multicolumn{2}{|l|}{ Običajna poslovna obleka } \\
\hline $\begin{array}{l}\text { srajca z dolgimi rokavi (lahko s črtico } \\
\text { ali karom); } \\
\text { kravata; } \\
\text { temne hlače in suknjič (lahko obleka); } \\
\text { temne nogavice; } \\
\text { temno rjavi ali črni usnjeni čevlji; } \\
\text { primerna mehanska ura; } \\
\text { poročni prstan (če je poročen). }\end{array}$ & $\begin{array}{l}\text { obarvana bluza ali top z rokavi; } \\
\text { suknjič iz blaga-lahko obarvan: } \\
\text { krilo ali hlače iz blaga, lahko obarvano; } \\
\text { temne nogavice; } \\
\text { usnjeni zaprti čevlji; } \\
\text { nakit (ne pretirano). }\end{array}$ \\
\hline \multicolumn{2}{|l|}{ Poslovna obleka managerjev } \\
\hline $\begin{array}{l}\text { bela ali svetlo modra vrhunska srajca } \\
\text { z dolgimi rokavi iz primerne tkanine; } \\
\text { lahko manšetni gumbi; } \\
\text { kravata; } \\
\text { temno modra ali temno siva ali črna } \\
\text { obleka iz volnene tkanine; } \\
\text { črne nogavice; } \\
\text { črni usnjeni čevlji na vezalke; } \\
\text { vrhunska mehanska ura; } \\
\text { poročni prstan (če je poročen). }\end{array}$ & $\begin{array}{l}\text { kakovostna bluza z dolgimi rokavi; } \\
\text { temno moder ali temno siv ali črn kostim } \\
\text { s krilom; } \\
\text { krilo naj sega do višine dveh prstov nad } \\
\text { kolenom; } \\
\text { črne nogavice; } \\
\text { črni usnjeni čevlji; } \\
\text { diskreten nakit. }\end{array}$ \\
\hline
\end{tabular}

Od mangerjev se pričakuje primerna poslovna obleka. Razlike med poslovno obleko managerjev in običajno poslovno obleko so:

- V čevljih: od managerjev se pričakujejo gladki črni čevlji z usnjenim podplatom. Biti morajo biti na vezalke. Pri običajni poslovni obleki so čevlji lahko tudi temno rjavi, ni nujno, da so čevlji gladki, podplat je lahko tudi iz drugih materialov.

- V kombinacijah: od managerjev se pričakuje obleka ali kostim ene barve, običajna poslovna obleka pa je lahko kombinacija hlač oziroma krila in suknjiča različnih barv.

- V barvah: od managerjev se pričakuje:

- bela ali svetlo modra srajca oziroma bluza;

- siva, modra ali črna poslovna obleka oziroma kostim;

- črne nogavice;

- črni čevlji. 
Pri običajni poslovni obleki pričakovane barve in kombinacije niso tako strogo določene.

- V vzorcih: od managerjev se pričakuje enobarvna srajca oziroma bluza, pri običajni poslovni obleki pa je srajca oziroma bluza lahko črtasta ali z vzorcem.

- V materialih: od managerjev se pričakuje obleka oziroma kostim iz volnene tkanine, običajna poslovna obleka pa je lahko iz mešanice materialov.

- V detajlih: od managerja se pričakuje:

- srajca brez prsnega žepa;

- mehanska ura »za obleko« (»dress watch $\left.\aleph^{23}\right)$ primerne kakovosti.

\section{POPOLNA VEČERNA OBLEKA (»WHITE TIE«)}

Popolna večerna obleka (White tie) se oblači za izjemne gala dogodke. Atributi popolne večerne obleke za moškega so:

- črne svilene nogavice;

- črni lakasti čevlji;

- črne gala hlače;

- bela večerna srajca;

- bel telovnik;

- črn frak;

- bel metuljček;

- ura za gala obleko.

Atributi popolne večerne obleke za ženske pa so:

- lakasti čevlji s peto;

- dolga gala obleka (obvezno „do gležnjev“!);

- lahko se vidijo ramena;

- dovoljen nakit.

\section{VEČERNA OBLEKA (»BLACK TIE«)}

Večerna obleka (Black tie) se oblači za gala večerne dogodke. Atributi večerne obleke za moškega so:

- črne nogavice;

- usnjeni črni čevlji;

- črna gala obleka/smoking;

- bela večerna srajca;

23 »Dress watch « je mehanska ura premera $38 \mathrm{~mm}$ (do največ 42mm), z dvema ali tremi kazalci, lahko tudi s funkcijo datuma, s čim bolj enostavno številčnico, na usnjenem, poleti lahko tudi na kovinskem paščku. 
- črn metuljček ali kravata;

- primerna ura.

Atributi večerne obleke za ženske pa so:

- lakasti čevlji s peto;

- dolga gala obleka (obvezno „do gležnjev“");

- lahko se vidijo ramena;

- dovoljen nakit. 
Zaposleni in management 


\section{KOMPETENCE ZAPOSLENIH}

Kompetence so tista pridobljena znanja, spretnosti, navade ter prirojene zmožnosti posameznika, ki mu omogočajo opravljanje dela $\mathrm{v}$ skladu s pričakovanji delodajalca in strank. Pričakovanja delodajalca se nanašajo na: vsebino dela, na zahteve glede kakovosti rezultata dela, na porabo virov, na časovne okvire in na dosego kriterija izvršitve.

Pričakovanja strank pa se poleg naštetega nanašajo še na vse tiste dejavnike, ki vplivajo na to, ali bo stranka zadovoljna ali ne. Kompetence zato niso zgolj »mehanističen« opis vseh znanj, spretnosti, navad in sposobnosti posameznika. Kompetence vključujejo tudi druge dimenzije, kot so npr.: iznajdljivost, samoiniciativnost, prijaznost in številne druge.

Ljudje iz okolja (npr. poslovni partnerji in kupci), ki so $\mathrm{v}$ interakciji $\mathrm{z}$ nekom iz organizacije, nedvomno zelo hitro zaznajo kompetentnost človeka. Kaj kmalu ugotovijo:

- če je nek član organizacije opravil tisto, kar so se dogovorili;

- če ima znanja in zmožnosti, da bi delo opravil;

- če pozna metode dela;

- če je bil pripravljen sodelovati;

- če se je obnašal korektno;

- idr

Ker so atributi kompetenc zaposlenih objekt zaznav ljudi iz okolja, so del identitete organizacije. V organizacijah preučujemo kompetence posameznikov, kot tudi kompetence organizacije kot celote.

Kompetence organizacije so zmožnost, da se izpelje dogovorjeni posel v dogorjenih rokih in na dogovorjen način. Kompetence organizacije so sestavljene iz kompetenc posameznikov. Vendar morajo biti kompetence organizacije več, kot je vsota vseh kompetenc zaposlenih. 
124 POSLOVNO KOMUNICIRANJE

Zaposleni in management 


\section{ZAVZETOST ZAPOSLENIH}

Objekt zaznavanja ljudi iz okolja je tudi zavzetost zaposlenih. To zlasti velja, kadar imao opravka s storitvami.

Zavzetost zaposlenega pomeni njegov osebni trud, ki ga vlaga $\mathrm{v}$ delo. Treba je razlikovati med zavzetostjo in zadovoljstvom na delovnem mestu. Kruse (2012) pravi, da podjetje lahko ponudi zaposlenim vse možne bonitete. To sicer lahko pomeni, da bodo zaposleni bolj zadovoljni. Ni pa nujno, da bodo zadovoljni zaposleni tudi zavzeti.

Za prvega, ki je začel znanstveno preučevati zavzetost zaposlenih velja William Kahn. Kahn (1990) je preučeval, kakšen je odnos med zaposlenimi in njihovimi delovnimi nalogami. Izhajal iz teorij organizacijskega vedenja iz petdesetih in šestdesetih let prejšnjega stoletja. Preučeval je, če na osebno zaznavanje pomena dela zaposlenega vplivajo spremenljivke:

- medosebni odnosi;

- delovna skupina;

- odnosi v skupini;

- kontekst organizacije.

Postavil je dve hipotezi:

1. Na vrednote in behaviorizem zaposlenega vplivajo psihološke izkušnje pri delu.

2. Na psihološke izkušnje zaposlenega vplivajo: medosebni odnosi, delovna skupina, odnosi $\mathrm{v}$ skupini, kontekst organizacije in dejavniki znotraj posameznika.

Opravil je dve vzporedni raziskavi v dveh popolnoma različnih organizacijah:

- v poletnem delovnem kampu, kjer je šest tednov prostovoljno delalo približno 100 mladostnikov;

- $\quad \mathrm{v}$ arhitekturnem biroju, ki je veljal za prestižnega in kjer je bilo zaposlenih 45 ljudi.

Ugotovil je, da je zavzetost in nezavzetost zaposlenih treba obravnavati popolnoma ločeno, ker sta to dve ločeni kategoriji.

Osebna zavzetost je simultan odziv človeka in prednostno odraža človeka samega. Z osebno zavzetostjo človek sam odraža svojo povezanost $\mathrm{z}$ delovno nalogo in z ostalimi, ki so s tem v zvezi. Ljudje, ki so zavzeti, imajo v sebi lastnosti, kot so energija, kognitivne sposobnosti, ipd. Te se odrazijo v delovnem naporu. Kahn (1990) je nadalje ugotovil, da 
obstaja tudi povezanost med osebno zavzetostjo, in pomenom, ki ga zaposleni pripisuje naslednjim trem dejavnikom:

- Smiselnost delovne naloge pomeni »občutek povrnitve vložka v izvedbo delovne naloge«.

- Varnost pomeni občutek ostati zaposlen, brez strahu za zaposlitev, samopodobo in lastno kariero.

- Razpoložljivost pomeni imeti fizično energijo, čustva in mentalno energijo, potrebno za izvedbo delovne naloge.

V nasprotju s tem pa osebna nezavzetost pomeni simultan umik človeka samega, avtomatsko obrambno reakcijo in prednostno odraža skrivanje prave identitete.

Na podlagi te raziskave so bile $\mathrm{v}$ naslednjih letih opravljene številne druge znanstvene raziskave. V Evropi se je s tem področjem zelo ukvarjala Univerza v Utrechtu, še posebej Wilmar B. Schaufeli. Za merjenje zavzetosti zaposlenih je bil razvit poseben model, imenovan Utrecht Work Engagement Scale (UWES).

Svetovalne agencije so razvile številne komercialne lestvice za merjenja zavzetosti, katere so. Ena od najbolj uporabljenih je Gallupov vprašalnik Q12. Gallupov pristop na podlagi 12 vprašanj razvrsti zaposlene $\mathrm{v}$ tri kategorije:

- zavzeti;

- nezavzeti;

- aktivno nezavzeti.

Pristop razvrščanja zaposlenih v kategorije po Gallupovem vprašalniku Q12 je nekoliko drugačen, kot ga je imel William Kahn. Zaposlene kategorizira v tri skupine in ne v dve. Tretja kategorija zaposlenih po Gallupovem vprašalniku Q12 so »aktivno nezavzeti«. To so tisti, ki aktivno izražajo svoje nezadovoljstvo. 


\section{NOTRANJA KOHEZIVNOST}

Nobena organizacija navznoter ni popolnoma monolitna. Monolitnost v organizaciji je lahko celo škodljiva, saj pomeni, da ni novih idej, predlogov in inovacij.

Organizacija mora biti homogena v razumevanju skupnih ciljev in vrednot.

Popolnoma običajno je, da se znotraj organizacij pojavljajo različne neformalne organizacije. Posamezniki imajo lahko tudi različne interese in pojavljajo se notranja rivalstva. Inovativnost, rivalstva in notranji »mnenjski trg« sta ključna notranja generatorja razvoja. Obstoj notranjega mnenjskega trga, rivalstva, inovativnost in neformalne organizacije pomenijo neke vrste dopustno hetrogenost. Ta še vedno omogoča udejanjanje skupnih vrednot in doseganje skupnih ciljev. Meja pa je prekoračena $\mathrm{v}$ trenutku, ko rivalstva preidejo $\mathrm{v}$ boj za prevlado ali ko pride do zavestnega upiranja. To je že pokazatelj pojava dveh ali več identitet. V primeru pojava dveh ali več identitet člani organizacije navzven pošiljajo protislovna sporočila o isti zadevi. Daljše ko je trajanje boja za prevlado ali upiranja, večja je verjetnost, da si bodo akterji poiskali pomoč zunaj organizacije. . Okolje ta sporočila seveda zaznava.

Obstajajo številni opisi škodljivih posledic notranje neenotnosti organizacije. Sema Hande Ogutcu-Fu (2016) je analizirale državljanjske vojne v obdobju od leta 1980 do 2005. Njene ugotovitve kažejo, da se v vsaki vojni pojavi utrujenost in celo popolna izčrpanost vpletenih strani. Utrujenost pri vseh vpletenih povečuje pripravljenost na pogajanja. Vendar pa do dogovora in poravnave med vpletenimi pride le, če znotraj vpletenih skupin obstaja notranje soglasje.

Tipičen pojav slabe notranje kohezivnosti je pojav žvižganja in žvižgačev. Žvižganje je pojav, ko oseba, ki ima dostop do "notranjih informacij” poskrbi za nepooblaščeno posredovanje in objavo informacij o :

- dejanskih nepravilnostih ali

- zgolj namišljenih nepravilnostih,

zaradi:

- moralnih in etičnih vzgibov, ali

- zaradi maščevanja, sovraštva, ali nevoščljivosti.

To povzroči neugodno publiciteto o organizaciji in materialno škodo. Ta pojav ima že več kot stoletno zgodovino. V teoriji je dokaj dobro raziskan. Harrison (1995) meni, da prve pojave žvižganja lahko zaznamo konec 19. in v začetku 20. stoletja. Leta 1902 je revija Magazine McClure objavila serijo člankov o korupciji na visokih mestih v New Yorku. 
Obstajajo različne definicije žvižganja. Vsem definicijam je skupno to, da gre pri pojavu žvižganja za posredovanje sporočil o nepravilnostih v organizaciji zunanjemu okolju.

Izpostaviti velja Jubbovo (1999) definicijo žvižganja, ki pravi, da je žvižganje neobvezno dejanje razkritja, storjeno s strani nekoga, ki ima ali je imel privilegiran dostop do podatkov ali informacij v organizaciji o ne trivialnih nezakonitostih ali drugih kršitvah, ki se dogajajo pod nadzorom organizacije, in da ima kot zunanji subjekt možnost opozoriti na nepravilnosti. Razčlemba žvižganja po Jubbu je podana v tabeli 2.

Tabela 2: Splošna definicija in razčlemba žvižganja (Jubb, 1999)

\begin{tabular}{|l|l|l|}
\hline Element & Cilj & Opis \\
\hline Akcija & Razkritje & Premišljena \\
\hline Rezultat & Javni viri & Neobvezno \\
\hline Akter & $\begin{array}{l}\text { Oseba, ki ima privilegiran dostop do } \\
\text { podatkov in informacij organizacije }\end{array}$ & $\begin{array}{l}\text { Trenutni ali bivši zaposleni } \\
\text { organizacije }\end{array}$ \\
\hline Subjekt & O nezakonitostih ali nepravilnostih & $\begin{array}{l}\text { Ne trivialni, aktualni } \\
\text { dogodki }\end{array}$ \\
\hline Tarča & Se tiče organizacije & $\begin{array}{l}\text { Dogodki pod nadzorom } \\
\text { organizacije }\end{array}$ \\
\hline Prejemnik & Zunanja javnost & Preprečiti nepravilnosti \\
\hline
\end{tabular}

Tipične vsebine žvižganja so:

- finančne nepravilnost;

- klientelizem;

- korupcija;

- ogrožanje zdravja;

- napake na proizvodih;

- poročila o kartelnem dogovarjanju;

- poročila o drugih nečednostih (npr. prisluškovanje, ...).

Pri presoji etičnosti ravnanja žvižgačev se kot kriterij etičnosti vrti v glavnem okoli iskanja razmerja med škodo, ki jo naredi neetično ravnanje organizacije oziroma managementa in škodo, ki jo ravnanje žvižgača povzroči organizaciji. Mnogi trdijo, da gre v primeru žvižgačev za visoko etično ravnanje. Nekateri žvižgače imenujejo moralni heroji. Drugi pa žvižgače imenuje podgane. Žvižgači namreč neredko razširjajo tudi informacije, ki sploh niso resnične. Velasquez (1992) tako pravi, da je škoda, ki jo organizaciji povzročijo žvižgači lahko večja, kot katerakoli ekonomska katastrofa.

Anketirali smo 969 zaposlenih oseb. V vzorcu je bilo 443 (45,6\%) moških in $526(54,4 \%)$ žensk. Starostna struktura vzorca je bila reprezentativna. Anketirancem smo postavili vprašanja:

Ali bi bili samoiniciativno pripravljeni morebitne sume nepravilnosti v vaši organizaciji kdaj posredovati $\mathrm{v}$ objavo medijem? V vprašalniku smo ponudili pet odgovorov (od »nikoli« do »seveda, brez pomisleka«). 
Iskali smo morebitne povezave pripravljenosti za žvižganje z:

- zadovoljstvom s komuniciranjem v organizaciji;

- demografskimi atributi zaposlenega (starost, spol, izobrazba, stan);

- stilom vodenja v organizaciji.

Samo 3,6\% vprašanih bi bilo brez pomisleka pripravljenih posredovati informacije o morebitnih nepravilnostih v okolje. Povezav med starostjo, spolom izobrazbo in stanom ter stopnjo pripravljenosti za žvižganje nismo odkrili. V raziskavi smo prepoznali pomembno povezavo med nepriljubljenostjo vodje in pripravljenostjo ljudi za žvižganje.

Ko smo analizirali nekatere primere žvižganja v Sloveniji, smo ugotovili, da je bilo povsod govora tudi o slabi komunikaciji v organizacijah. Molk torej krizo lahko ustvari, če pa kriza nastane, jo molk samo še poglobi.

S skrbjo za interno komuniciranje se lahko zmanjša verjetnost za pojav »žvižganja. Tudi v idealni organizaciji se pojava neupravičenega žvižganja ne da povsem preprečiti!

S pojavom interneta in socialnih spletnih omrežij so se žvižgačem odprle nove možnosti. Zlasti s pojavom WikiLeaks-a je po letu 2010 pojav dobil povsem nove razsežnosti. 
Zaposleni in management 


\section{SIMBOLIKA MANAGEMENTA}

Simbolika managementa je sistem simbolov, ki so objekt zaznave o obstoju in delovanju managerja.

Obstoj inštitucije managementa je bil skozi vso zgodovino družbena realnost. V zgodovini so obstajale različne pojavne oblike in različna imenovanja. Obstajali so poglavarji plemen, faraoni, kralji, cesarji, vse do današnjih direktorjev in predsednikov uprav. Spremljali so jih simboli, za katere se je v posameznih zgodovinskih obdobjih zdelo, da jim pritičejo. $\mathrm{V}$ različnih zgodovinskih obdobjih in $\mathrm{v}$ različnih kulturah so obstajale številne pojavne oblike.

Eden od atributov kulture družbe je tudi odnos do moči. Nedvomen razlog za obstoj simbolov je bila potreba po avtoriteti in prikazu moči. Avtoriteta je moč in pravica presojanja in sprejemanja končnih odločitev. Moč pa je sposobnost uveljavljanja svoje volje. Ljudje so morali vedeti, kdo ima avtoriteto in moč. Preko različnih simbolov jim je bilo to treba sporočiti. Simboli so vključevali mnoge in po svoji naravi popolnoma različne atribute: od obleke in obutve, pa vse do etičnosti ravnanja managerja.

Winkler (2013) pravi, da vsebinski okvir simbolike managementa odraža realnost organizacije. Preko njih notranje in zunanje javnosti zaznajo:

- dejstvo o obstoju managerja kot inštitucije in kot osebe;

- managerja kot osebo;

- status managerja;

- moč managerja;

- motivacijo managerja;

- stopnjo nadzora managerja nad organizacijo;

- "notranji družbeni red « znotraj organizacije;

- kulturo organizacije in kulturo družbe nasploh.

Kot nadalje pravi Winkler (2013), simbolika managementa danes odraža tudi:

- kaj vodja sploh je;

- kaj vodja dela;

- kaj vodja misli;

- kakšne so njegove vrednote in

- kakšne so njegove interakcije znotraj organizacije in navzven.

Univerzalno veljavne vsebine simbolov ni mogoče predpisati. Organizacije imajo namreč zelo različne kontekste in zelo različna okolja: 
- Ukvarjajo se z zelo različnimi dejavnostmi.

- Delujejo v različnih socialnih in kulturnih okoljih.

- Imajo različna pričakovanja poslovnih partnerjev in strank.

- Imajo različne zgodovine.

Na vsebino simbolov vplivajo interakcije med:

- managerjem;

- člani organizacije;

- okoljem.

To z drugimi besedami pomeni, da se vsi trije dejavniki neprestano medsebojno prilagajajo. Manager se s svojo simboliko mora prilagajati pričakovanjem organizacije in okolja, hkrati pa tudi sam spreminja organizacijo in okolje. Kljub stalnim medsebojnim interakcijam ima simbolika managementa svoj vsebinski okvir. Ta je zgodovinska stalnica.

Simbolika managementa kljub razlikam med organiazcijami in managerji ima svojo »logiko«. Vse pojavne oblike simbolov imajo kljub navidezni različnosti in za koga morda celo nepomembnosti, vendarle skupni namen. Skupni namen je, da oblikujejo »presenco managerja «. Presenco managerja je mogoče zaznati iz številih atributov. Sestavlja jo:

- osebni videz;

- dostojanstvo;

- osebna odličnost;

- občutek za realnost;

- samozavest

- izobrazba;

- drugo.

McKnight (2013) pravi, da je presenca managerja medsebojno prepletanje štirih dimenzij:

- Ustreznost se odraža v skrbi za osebni videz, v primernem obnašanju in v socialnih spretnostih.

- Zaupanje se odraža $v$ pravilnosti odločitev in ravnaj $\mathrm{z}$ vidika spoštovanja zakonov, etike in družbenih norm.

- Kompetence so znanja, spretnosti, navade ter prirojene zmožnosti. Odražajo se $\mathrm{v}$ profesionalnosti ravnanja.

- Konsistentnost je doslednost ravnanja skozi daljše časovno obdobje.

V zadnjih desetletjih so se pri preučevanju managerjev pojavila tudi vprašanja izobrazbe. Eno prvih obsežnejših znanstvenih raziskav o tem, kako rangiranje univerze vpliva na možnost zaposlitve diplomantov na top managerski poziciji, so opravili Jalbert in 
soavtorji (2002). Ugotovili so, da so v obdobju med letoma 1987 in 1996 v ZDA kar $12,5 \%$ položajev predsednikov uprav največjih korporacij zasedali diplomanti zgolj petih najbolj prestižnih univerz. Raziskava je bila ponovno opravljena leta 2010. Po ugotovitvah te raziskave so diplomanti Harvarda zasedali kar 11,5\% mest predsednikov uprav. 
134 PosLOVNO KOMUNICIRANJE

Zaposleni in management 


\section{PROTOKOL}

Protokol je »predpisan postopek« za pripravo in potek formalnih dogodkov.

Beseda »protokol« ima sicer lahko več pomenov: ${ }^{24}$

- uradna in državna pravila za stike predstavnikov držav;

- mednarodni dogovor, navadno o določenem vprašanju, navadno zapisan v pisni obliki;

- zapisnik o poteku sestanka, kjer se ne še doseže končnega soglasja oziroma sporazuma (protokol je nižja oblika kot sporazum).

Ob obravnavi protokola navadno pomislimo na državniške sprejeme. Uradna pravila za stike predstavnikov držav so bila obravnavana leta 1815 na Dunaju. Tam je bil glede tega vprašanja tudi dosežen dogovor. Mednarodno pravno pa vprašanja protokola ureja Dunajska konvencija o diplomatskih odnosih iz leta 1961. Tudi znotraj države se ob posameznih dogodkih morajo upoštevati načela protokolarnega reda.

Protokol pa se ne nanaša zgolj na meddržavne odnose in pomembne dogodke znotraj države. Tudi druge organizacije (npr.: podjetja, društva, univerze in druge inštitucije) imajo svoja protokolarna pravila. Protokol namreč odraža identiteto vsake organizacije.

Spoštovanje protokola se nanaša na dogodke, kot:

- $\quad$ sprejem in pospremitev gostov na formalnih obiskih;

- podpisovanje pogodb in sporazumov;

- formalni pogovori;

- polaganje vencev in odkrivanje spomenikov;

- pogrebi in maše zadušnice;

- slovesni obedi;

- drugo.

Protokol predpisuje:

- način oblačenja udeležencev;

- način in vrstni red rokovanja;

- uporabo posameznih ceremonialnih pravil;

- geste spoštovanja gosta;

- način prevozov gostov in spremstva;

- sedežni red ob obedih;

\footnotetext{
${ }^{24}$ Glej npr.: Slovar slovenskega knjižnega jezika.
} 


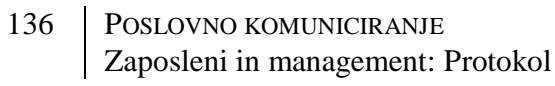

- jedilnik;

- prisotnost medijev;

- obdarovanje;

- drugo. 
PoSLOVNO KOMUNICIRANJE

M. Ferjan

\section{SPLETNO KOMUNICIRANJE ORGANIZACIJ}





\section{DIGITALNA SUVERENOST}

Internet ponuja organizacijam široko paleto možnosti, ki prej niso obstajale. Vse možnosti interneta presegajo okvire klasičnega oglaševanja, odnosov z javnostmi, kriznega komuniciranja in odnosov z vlagatelji. Če neka organizacija objavi ustrezno pripravljen video prispevek na YOUTUBE, ne moremo tega šteti za oglas, niti ne moremo trditi, da je to prispevek, ki se nanaša na odnose z javnostmi. Če je priprava ustrezna, gre za oboje hkrati. Ustrezna priprava in objava ima lahko velik pomen tudi $\mathrm{v}$ primeru morebitne potrebe po kriznem komuniciranju, saj se sporočila »shranjujejo« v spominu prejemnika. To se je pokazalo v primeru škandala vozil podjetja Volkswagen pri testih porabe goriva. Objava škandala je pri potrošnikih nedvomno povzročila kognitivno disonanco, vendar je bila pred tem akumulacija pozitivnih kognicij o podjetju pri potrošnikih tako velika, da ta škandal na prodajo vozil podjetja Volkswagen sploh ni vplival.

Do pozitivnih kognicij lahko pride le, če sporočilo posameznik dobi od vira, ki ga ima za zaupanja vrednega. Poleg kredibilnosti vsebine sporočila je potrebna tudi kredibilnost kanala, prek katerega se vsebina prenese. Kognicije in sheme lahko nastanejo zgolj:

- če vsebine sporočila prejemnika šteje za kredibilne;

- če prejemniki sporočil tudi kanale štejejo za kredibilne;

- če je sporočanje kredibilnih vsebin preko kredibilnih kanalov kontinuirano.

Da bi vse to zagotovili, se mora komuniciranje organizacije preko interneta izvajati $\mathbf{v}$ funkciji integralnega komuniciranja organizacije. Integralno komuniciranje je sporočanje vsega, kar se nanaša na identiteto organizacije. Do določene mere s tem odpade tudi dosedanje ločevanje komuniciranja navznoter in komuniciranja navzven.

Rezultati raziskav (npr.: Rybalko, Seltzer, 2010) so pokazali, da je bila večina od »tweetov« podjetij iz lestvice FORBES 500 namenjena širši javnosti (74,5\%), sledijo objave usmerjene na določenega uporabnika $(23,7 \%)$, na kupce $(0,9 \%)$, na "druge" ciljne skupine $(0,5 \%)$, in šele nazadnje na zaposlene $(0,4 \%)$.

Komuniciranje organizacij preko interneta organizacijam omogoča vsaj eno, praviloma pa več funkcij:

- stalen stik s ciljnimi skupinami in javnostmi;

- neprestano zaznavanje potreb, želja in pričakovanj javnosti in ciljnih skupin;

- neprestano odzivanje na potrebe, želje in pričakovanja javnosti in ciljnih skupin;

- neprestano obveščanje o pozitivnih dogodkih v organizaciji;

- sprotno preverjanje možnosti pojava informacij, ki bi bile za organizacijo negativne in s tem pojava negativnih kognicij; 
- sprotno odzivanje na neželena sporočila;

- vzpostavitev lastnega socialnega omrežja in foruma;

- vključevanje ali celo moderiranje vsebine komuniciranja na obstoječih socialnih omrežjih;

- spodbujanje ali celo organiziranje tistih aktivnosti članov socialnih omrežij, ki pozitivno vplivajo na image organizacije;

- distribucija oglasov;

- neprestano spremljanje konkurence;

- drugo.

Bistvena prednost komuniciranja organizacije prek spleta je $\mathrm{v}$ tem, da:

- Lahko sama kreira sporočila.

- Lahko sama izbira in upravlja s kanalom komuniciranja.

- Ni vezana na kanal za prenos sporočil, kot je to npr.: časopis, radio ali televizija.

- S komuniciranjem preko spleta praktično nima stroškov za plačilo kanala.

- Lahko sama upravlja s časom, v katerem bo poslala sporočila.

- Lahko sama in takoj pridobiva povratne informacije od tistih, ki so sporočila prejeli.

Vsaka organizacija, ki uporablja internet, se slej ko prej sooči z vprašanji »digitalne suverenosti

Digitalna suverenost je nadzor nad sedanjostjo in dogodki, ki se manifestirajo z uporabo informacijske tehnologije in računalniških omrežij. Nanaša se na zanesljivost, celovitost in razpoložljivost strojne in programske opreme, omrežij ter prenos, obdelavo in shranjevanje podatkov.

Digitalna suverenost se nanaša na:

- tehnična vprašanja;

- vprašanja, vezana na vsebine uporabe interneta;

- vprašanja zagotavljanja varnosti.

Vsaka organizacija se mora sama odločiti:

- katero strojno in programsko opremo bo uporabljala;

- kateri podatki in kje se lahko zbirajo, distribuirajo, uporabljajo in shranjujejo,

- kdo bo imel nad tem nadzor.

Nad tehničnimi vidiki delovanja interneta v globalnem prostoru bdi Internet Engineering Task Force (IETF). IETF je bil ustanovljen leta 1986 v ZDA. Osnovna naloga IETF je razvoj tehničnih standardov in protokolov. Po svetu pa je seveda na tisoče komercialnih 
ponudnikov spletnih storitev. Mnoge organizacije si vsaj del tehničnih vidikov seveda zagotavljajo same.

Osnovna ideja interneta je izhajala iz načela odprtosti in dostopnosti. Sčasoma so se na internetu pojavili številni ponudniki različnih storitev. Uporabniki interneta so postali ljudje iz različnih kulturnih, verskih, ekonomskih in političnih okolij. Dejavniki, kot so:

- različni poslovni, politični in drugi interesi;

- raznolikost uporabnikov in

- hkratna odprtost ter splošna dostopnost interneta

so prinesli tudi kibernetske napade in druge neželene pojave.

Za enega prvih kibernetskih napadov se šteje kibernetski napad na strežnike NASA decembra leta $2006 .^{25}$

Vsaka organizacija mora na vprašanja v zvezi z digitalno suverenostjo odgovoriti:

- Kaj je sploh za organizacijo pomembna vsebina digitalne suverenosti?

- Kdo v organizaciji o digitalni suverenosti odloča?

- Kdo operativno izvaja funkcije, ki so vsebina digitalne suverenosti?

- Kakšni so stroški in katere so koristi digitalne suverenosti?

Šele, ko organizacija odgovori na ta vprašanja, lahko začne s spletnim komuniciranjem.

Faze spletnega komuniciranja so:

1. sprejem odločitve o posredovanju informacije:

2. izbor kan;ala, oblikovanje vsebine sporočil in izbor formata;

3. kreiranje ustreznega formata sporočila;

4. objava ali druga oblika oddaje sporočila;

5. odzivanje na povratne informacije;

6. vrednotenje učinkov.

${ }^{25}$ VIR: http://www.nato.int/docu/review/2013/Cyber/timeline/EN/index.htm 
Spletno komuniciranje organizacij: 


\section{ODLOČITEV O POSREDOVANJU VSEBINE}

Crawford (2014) pravi, da si moramo pred odločitvijo o uporabi kanalov na internetu, odgovoriti na vprašanja:

- Ali ima osebje organizacije čas in znanje, da se sploh ukvarja $\mathrm{s}$ komuniciranjem preko internetnih kanalov?

- Ali organizacija lahko trajno vzdržuje aktivnosti komuniciranja na spletu, npr.: aktivnosti na družabnih omrežjih, forumih, blogih in mikroblogih; ne le enkratno objavo vsebin, pač pa tudi spremljanje povratnih informacij in odzivanje?

- Ali tudi ciljne skupine in javnosti ter drugi deležniki organizacije uporabljajo te kanale?

- Kakšne so želje in pričakovanja lastnikov glede tega?

Najpomembnejša kriterija za izbiro digitalnega medija sta:

- Kakšen socialni kapital bo aktivnost prinesla?

- Kdo so osebe, ki imajo največji vpliv na oblikovanje »socialnih shem« članov družbenih omrežij in na kakšen način funkcionirajo?

Socialni kapital je skupek dejanskih ali potencialnih virov, ki so povezani s posedovanjem trajne mreže bolj ali manj institucionaliziranih odnosov, vzajemnega poznanstva in priznanja. (Bourdieu, 1986)

Socilani kapital so torej možne koristi od članstva v skupini.

Mnenja o socialnem kapitalu iz naslova vključevanja organizacije v družbena omrežja so deljena.

Williams (2015) povzema, da za organizacije:

- po eni strani obstajajo pozitivne interpretacije učinkov socialnega kapitala družbenih omrežij, saj ta omogoča doseganje ciljev, ki jih v odsotnosti ne bi bilo mogoče doseči;

- po drugi strani pa so člani skupnosti tudi tisti, ki v družbenih omrežjih ne sodelujejo, in so kljub temu lahko koristni za organizacijo.

Družabna omrežja običajno funkcionirajo tako, da se ljudje v dani spletni skupnosti najprej med seboj »virtualno« spoznajo. Nato se sčasoma oblikuje navada aktivnosti. Motiv za aktivnost je lahko zabava, socialni stiki ali osebni užitek. Sčasoma lahko spreten moderator družbenega omrežja ta socialni kapital usmerjena k nekemu cilju. Organizacija 
si mora odgovoriti na vprašanje, ali bo preko družabnih omrežij lahko razvila zaupanje in vzajemnost, ki sta potrebni za uspešno sodelovanje.

Ostala vprašanja, ki jih povzema Williams (2015) so še:

- Ali je neko družbeno omrežje trivializirano?

- Kakšna je stopnja komercializacije?

- Ali je vsebina zanimanja članov omrežja skladna z našimi potrebami, ali jih bolj zanima kaj drugega (npr.: spektakel, erotika, ipd.)?

- Ali je struktura članov homogena?

- Kakšna je stopnja zavzetosti članov družbenega omrežja za vključevanje v realno življenje?

- Kakšen je dejanski družbeni in tržni vpliv družbenega omrežja na obnašanje članov v realnem svetu?

- Kolikšna je stopnja zaupanja med člani družabnega omrežja in v omrežje kot tako?

Nenazadnje si je treba postaviti tudi vprašanja o ugledu družbenega omrežja, v katerega se organizacija želi vključiti. 


\section{KANAL, VSEBINA, FORMAT}

Po tem, ko sprejmemo odločitev o komuniciranju glede neke vsebine, vzporedno izvajamo procese:

- izbire kanala;

- formuliranja vsebine sporočanja;

- izbora formata.

Najprej je treba izbrati ustrezen kanal. Pri izboru kanala je potrebno biti pozoren zlasti na naslednje:

- Ali kanal doseže želeno občinstvo?

- Kakšna je lastnost kanala iz vidikov, katere smo že opisali?

- Ali kanal za občinstvo, h kateremu se želimo obrniti s sporočilom, velja za zaupanja vrednega?

Spletne kanale komuniciranja lahko razvrščamo po številnih kriterijih:

- glede na tehnične lastnosti (npr.: sposobnost prenašanja golega teksta, slik, besedila, video vsebin, hiperbesedila, interaktivnost, ipd.);

- glede na namen obstoja (zasebno interpersonalno komuniciranje, formalno komuniciranje med člani organizacij, zabava, pridobivanje poslovnih informacij, druženje interesnih skupin, izražanje stališč, idr.)

- drugo.

$\mathrm{V}$ času uporabe te knjige se bo morda pojavil kak nov kanal, ki bo imel lastnost, ki je danes morda sploh še ne poznamo.

Spletne kanale za distribucijo sporočil in za komuniciranje organizacije z okoljem lahko razvrstimo po različnih kriterijih na:

- kanale za distribucijo teksta (npr.: elektronska pošta);

- spletna družbena omrežja;

- mikrobloge in druge kanale za objavljanje kratkih sporočil;

- spletne strani;

- poslovne bloge;

- forume;

- portale;

- drugo. 
Vseh obstoječih možnosti komuniciranja preko spleta organizacija ne more uporabiti, ker za to nima resursov.

Za vsako organizacijo pa obstaja univerzalni kriterij razvrščanja spletnih kanalov, ki je ključen. To je odgovor na vprašanje: Ali je kanal vreden zaupanja?

V enem od predhodnih poglavij smo opisali teoretične razlage, na kakšen način pri ljudeh pride do kolektivne kognicije in do nastanka socialnih shem. Socialne sheme nastanejo in delujejo tako, da vir zaznave predstavlja informacija iz socialnega, okolja. Informacijo človek, ki je v interakciji s socialnim okoljem prejme od vira, ki ga ima za "zanesljivo osebo" oziroma za »zanesljiv vir«.

Kako pomemben je izbor kanala, ki je »zaupanja vreden«, sta dokazala Omilion-Hodges in McClain (2016). Pri raziskovanju anatomije krize sta uporabila nadzorovan eksperiment $\mathrm{v}$ katerem so razširili nadzorovano govorico (opozorilo) o streljanju v univerzitetnem kampusu. Opozorilo je bilo kasneje preklicano. Raziskava je potekala na vzorcu 289 študentov kampusa. Raziskovalce je zanimalo, pri katerem viru bodo študenti najprej iskali informacije o dogodku. V zvezi z opozorilom so študenti kreirali 867 sporočil. Najpogostejši prvi odziv na krizo je bilo medosebno komuniciranje med člani skupine (123 študentov oziroma 42,6). Samo 49 (17\%) se jih je najprej odzvalo na facebook profilu. $\mathrm{V}$ tem primeru se je pokazalo, da so ljudje iskali verodostojne informacije pri osebnih virih, katerim očitno najbolj zaupajo.

Glede na to, h kateremu občinstvu se obračamo, se je treba odločiti med:

- enkratnim sporočilom in

- konverzacijo.

Ni nujno, da je vsebina sporočila formulirana zgolj kot enosmerno sporočilo. Lahko je tudi konverzacija. Organizacija se lahko prek interneta poslužuje tudi kontinuiranih oblik konverzacije z ljudmi iz okolja.

Vsebina sporočila mora pojasniti neko konkretno zadevo ali nek problem. Pri oblikovanju vsebine je potrebno upoštevati še naslednje:

- Vsebina sporočila se mora nanašati na identiteto organizacije.

- Nujno je ločevanje zasebnega in poslovnega. Če oseba komunicira v imenu organizacije, morajo biti sporočila poslovna. Če pa komunicira kot zasebnik, se kanalov organizacije praviloma ne uporablja. Izjema so lahko člani uprave.

- Sporoćila mora vsebovati atribute uspešnega prepričevanja: etos, logos in patos.

- Vsebina mora odražati pravila retorike, ki je značilna za uporabljen kanal.

Izbor kanala in vsebine vpliva na to, kateri format je potrebno izbrati. Format lahko vsebuje: tekst, slike, video vsebine, interaktivne strani, povezave ali kombinacijo 
naštetega. Izbor in realizacija formata ni zgolj tehnično opravilo. Treba ga je obravnavati širše, saj zajema:

- izbor lingvističnih, slogovnih in oblikovalskih atributov, ki jih uporabniki izbranega kanala štejejo kot samoumevne;

- tehnično realizacijo, s katero se prilagodimo tehničnim zahtevam kanala. 
PoSLOVNO KOMUNICIRANJE

Spletno komuniciranje organizacij: 


\section{OBJAVA ALI ODDAJA}

Pred oddajo sporočila mora biti opravljena vsebinska, oblikovalska in tehnična recenzija. Po opravljenih recenzijah sledi odobritev in oddaja.

V vsaki organizaciji morajo biti funkcije v procesu komuniciranja razdeljene na:

- odločevalsko funkcijo;

- funkcijo priprave vsebine;

- funkcijo zagotavljanja spletne varnosti;

- tehnično-administrativno podporo.

Nekatere organizacije nimajo kadrovskih resursov za zapolnitev vsake od navedenih funkcij. Zato ena oseba lahko opravlja več funkcij. Možno je, da zaradi majhnosti organizacije ali zaradi specifike kanala vse faze opravi samo ena oseba. V vsakem primeru, tudi če funkcijo komuniciranja izvaja samo ena oseba, je treba vedeti:

- Pred oddajo sporočila je treba opraviti vse naštete faze.

- Pred oddajo sporočila je treba čistopis sporočila pregledati po: jezikovni, vsebinski in tehnični plati.

- Spletne strani je pred javno objavo treba preizkusiti v testnem okolju.

- Nekdo mora biti odgovoren za spletno varnost.

- Definirani morajo biti tehnični in organizacijski ukrepi za zagotavljanje varnosti.

- Treba je vedeti, kdo so uredniki spletne strani, podstrani, katere so njihove naloge in kdo je tehnični administrator.

- Treba je vedeti, kdo je pristojen za odobritev objave vsebin. 
POSLOVNO KOMUNICIRANJE

Spletno komuniciranje organizacij: 


\section{ODZIVANJE NA POVRATNE INFORMACIJE}

Proces spletnega komuniciranja organizacije z okoljem se $\mathrm{z}$ oddajo sporočila ne konča. Treba je spremljati, kakšni so odzivi. Način merjenja odzivov je odvisen od uporabljenega kanala in je lahko:

- štetje števila obiskovalcev, časov trajanja obiska in druge analiza obiska spletnih strani s posebnimi programskimi orodji;

- štetje števila bralcev sporočil, v kolikor medij in stopnja razvitosti programske opreme to omogočata;

- število odzivov na enkratna sporočila;

- vsebinska analiza komentarjev;

- identifikacija obiskovalcev, če tehnična sredstva in zakonodaja to omogoča;

- drugo.

Kadar gre pri komuniciranju organizacije z okoljem za konverzacijo, mora organizacija določiti odgovorno osebo, ki se sproti odziva na povratna sporočila. 
Spletno komuniciranje organizacij: 
PosLOVNO KOMUNICIRANJE

M. Ferjan

\section{MARKETINŠKO KOMUNICIRANJE}





\section{MARKETINŠKI KOMUNIKACIJSKI SISTEM}

Marketinško komuniciranje je izmenjava sporočil med organizacijo in zunanjim svetom, še posebej s kupci.

Namen komuniciranja pri izvajanju prodajne funkcije kot ene od poslovnih funkcij je:

- potencialnega kupca informirati o vseh atributih produkta ali storitve, z namenom, da se bo odločil za nakup;

- vzpostaviti tako organizacijsko strukturo med kupcem in prodajalcem, da bodo poslovni odnosi trajno nemoteno potekali.

Komuniciranje pri prodaji je enosmerno.

Marketinško komuniciranje je dvosmerno. Marketinški informacijski sistem sestavljajo ljudje, pripomočki in postopki, s katerimi pridobivamo, razvrščamo, analiziramo, ocenjujemo in posredujemo potrebne, pravočasne in točne podatke (Kotler, 1996).

Informacijske tokove pri izvajanju funkcije trženja je glede na namen zato treba obravnavati:

- med organizacijami ali subjekti znotraj prodajnega kanala, ki so v poslovnem odnosu pri izvajanju funkcije prodaje, torej od proizvajalca neke dobrine do tistega, ki dobrino neposredno proda končnemu kupcu;

- $\quad \mathrm{V}$ funkciji dvosmernega komuniciranja $\mathbf{z}$ dejanskimi ali potencialnimi končnimi kupci.

Prodajni kanal je struktura povezav, katere mora prepotovati produkt ali storitev na poti od proizvajalca do uporabnika (Brassington in Pettitt, 1997). Ko se odločimo za nastop na določenem trgu, moramo proučiti in izbrati ustrezne prodajne kanale.

Prodaja zahteva različne pristope do kupca. Vsak pristop zahteva specifična strokovna znanja. Tako poznamo različne tipe prodajalcev:

- delo prodajalca je zgolj sprejem naročil;

- delo prodajalca je sprejem naročil in dostava izdelka (npr.: dostava kurilnega olja na dom);

- delo prodajalca je zgolj obisk potencialnega kupca z namenom predstaviti izdelek;

- delo prodajalca, ki zahteva dobro poznavanje tehničnih karakteristik produktov in sposobnost informiranja kupcev o le-teh;

- drugo. 
Odločitev o tipu prodajalca je odvisna od številnih dejavnikov. Pomembno je upoštevati:

- vrsto in lastnosti produkta, katerega prodajamo;

- zahteve potencialnih kupcev;

- politiko organizacije;

- dejavnosti konkurenčnih ponudnikov;

- drugo.

Poznanih je več načinov prodaje končnemu kupcu. Prikazuje jih slika 5.

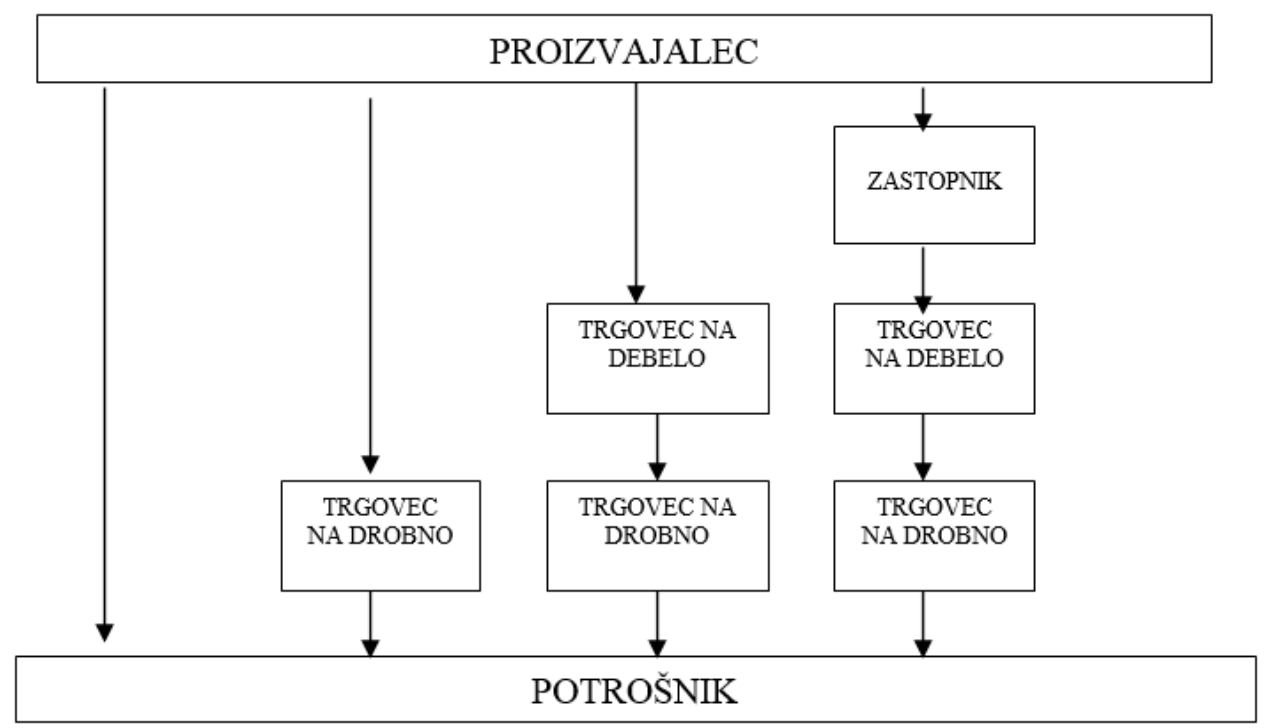

\section{SLIKA 5: Prodajni kanali}

Informacijske tokove pri izvajanju funkcije trženja prikazuje slika 6 . Kot je razvidno iz slike, je za realizacijo nakupa s strani končnega kupca potrebno komuniciranje:

- proizvajalca s trgovcem in končnim kupcem;

- trgovca s končnim kupcem. 


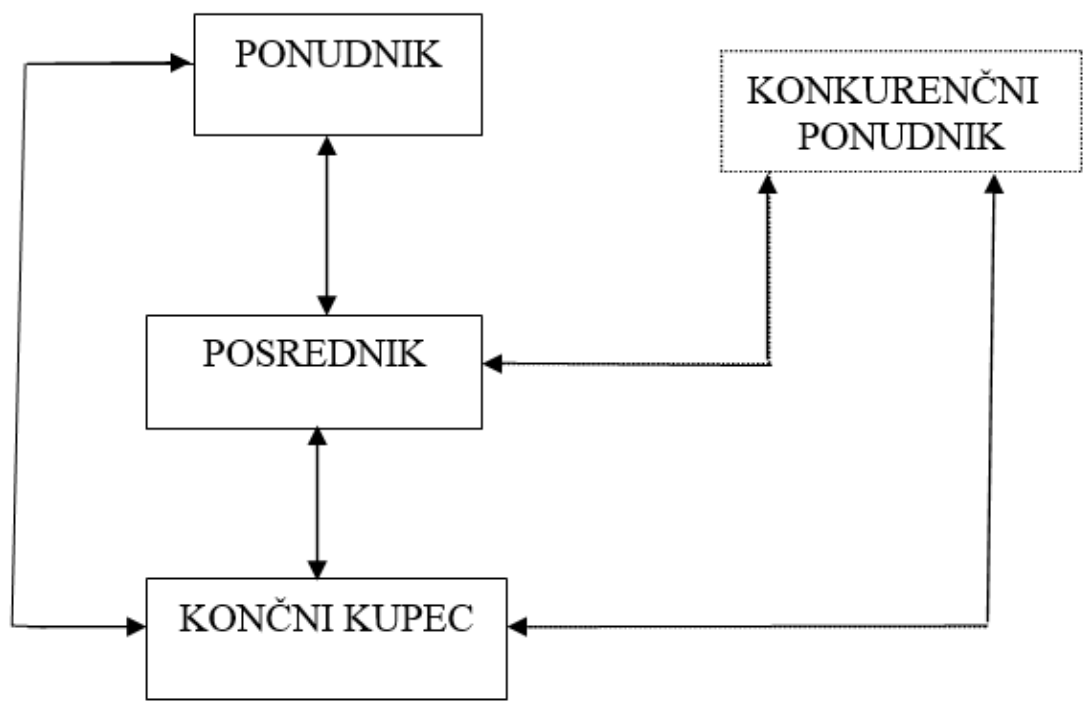

SLIKA 6: Informacijski tokovi pri izvajanju funkcije trženja.

Informacijski tokovi med posameznimi elementi znotraj prodajnega kanala so dvosmerni.

Poleg komuniciranja med proizvajalcem, posrednikom in končnim kupcem so prisotne tudi medorganizacijske komunikacije. Kot primer si oglejmo poenostavljeno shemo pretoka informacij, če gre za prodajo prek trgovca na drobno brez posrednikov. Prikazuje jo slika 7. 


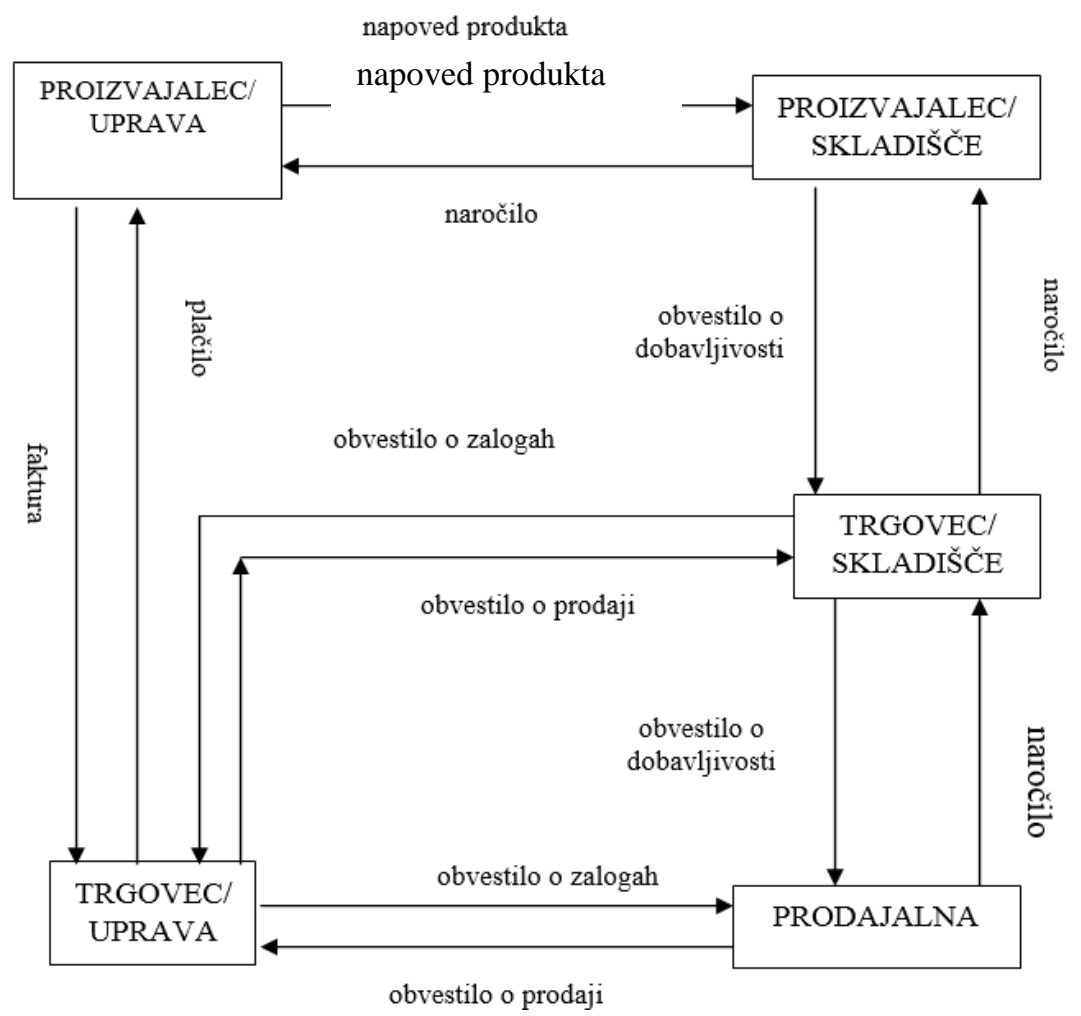

SLIKA 7: Poenostavljena shema pretoka informacij (Brassington in Pettitt, 1997).

Ključna sestavina marketinškega informacijskega sistema je komuniciranje $\mathbf{z}$ dejanskimi ali potencialnimi kupci. Marketinško komuniciranja $\mathrm{z}$ dejanskimi ali potencialnimi kupci ima dve vzporedni funkciji:

- vplivanje na behaviorizem potrošnikov $\mathrm{z}$ namenim doseči prostovoljno pripravljenost za nakup;

- zagotavljanje zadovoljstva strank.

Da bi lahko vplivali na behaviorizem potrošnikov, je treba razumeti mehanizme odločanja potrošnikov o nakupu. Eden prvih, a še danes uveljavljenih modelov razlage behaviorizma potrošnikov je AIDA model. Po splošnem prepričanju naj bi bil domnevni avtor tega modela Elias St. Elmo Lewis (živel od 1872 do 1948). AIDA model naj bi bil domnevno prvič predstavljen leta 1900, domnevno prvič objavljen pa leta 1904. AIDA model pojasnjuje, da potrošnikova odločitev o nakupu poteka $\mathrm{v}$ štirih stopnjah, ki so: zavedanje-interes-želja-akcija (Awareness-Interest-Desire-Action). 


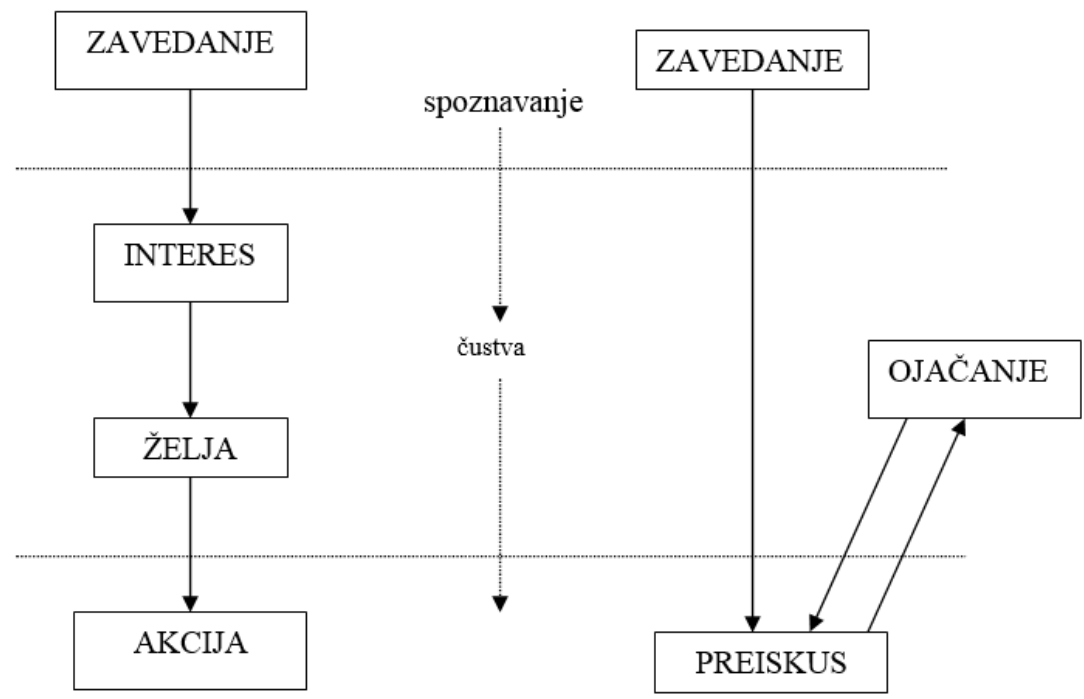

DRAGE DOBRINE

POCENI DOBRINE

\section{SLIKA 8: Proces odločanja o nakupu dobrin.}

AIDA model pojasnjuje, da odločanje potrošnika o nakupu poteka na:

- racionalni ravni, saj potrošnik v procesu nakupovanja izkazuje zanimanje oziroma interes in zato pri zasebnih in poslovnih virih zbira informacije o produktu in elementih nakupa;

- emocionalni ravni, saj je za realizacijo nakupa potrebna želja.

Da bi se potrošnik odločil za nakup, mora biti izpostavljen zaznavam. Zaznave morajo v njem povzročiti percepcije, kognicije in emocije, da bi na koncu procesa odločanja prišlo do nakupa.

Klasična pojavna oblika vplivanja na behaviorizem potrošnikov je promocijski splet. Vendar samo s promocijo pogosto ni mogoče doseči prostovoljne pripravljenosti za nakup. Nenazadnje je promocija zgolj eden od elementov marketinškega spleta. Narava promocije pogosto ne omogoča, da bi dejanski ali potencialni kupec:

- zgolj iz sporočil promocije dobil odgovore na vse prvine njegovega zanimanja in

- v sporočilih promocije zaznal atribute, ki v njem sprožijo zadosti močno čustvo želje po nakupu.

Zato je potrebno, da potencialni kupec zazna tudi atribute celotnega marketinškega spleta.

Drug, prav tako pomemben vidik marketinškega komuniciranja je zagotavljanje zadovoljstva. Kupec mora tako v procesu nakupovanja kot pri uporabi zaznati zaznave, 
Marketinško komuniciranje: Marketinški komunikacijski sistem

ki v njem sprožijo čustva zadovoljstva in ugodja. To zagotovimo z atributi celotnega marketinškega spleta. 


\section{MARKETINŠKI SPLET}

Koncept marketinškega spleta pomeni načrtno delovanje:

- za zadovoljitev potreb in zagotavljanje zadovoljstva kupca;

- na človekovo psiho z namenom ustvariti čim intenzivnejšo in dolgotrajno pripravljenost za nakup(ovanje) izdelka ali storitve.

Koncept marketinškega spleta izhaja iz temeljne filozofije marketinga. V obdobju prodajne organizacije je bil $\mathrm{v}$ ospredju sam produkt. S pojavom marketinga za zadovoljitev potrebe kupca postane pomembna še distribucija, cena in kasneje še drugi atributi. Svoj izvor naj bi koncept marketinškega spleta imel v tridesetih letih prejšnjega stoletja. Kot smo že pojasnili, naj bi se za imenovanje teh atributov fraza »marketinški splet« (marketing mix) začela uporabljati po 2. svetovni vojni. V prvotni obliki je marketinški splet imel 12 dimenzij. Koncept $\gg \boldsymbol{4 P}$ « (angl.: product-price-place-promotion oziroma slovensko: produkt-cena-prodaja-promocija) naj bi prvič v šestdesetih letih prejšnjega stoletja predstavil Jerome McCarthy. Konceptu 4P je bilo dodano še: procesiranje, ljudje in fizični dokazi (angl.: process, people and physical evidence).

V nadaljevanju bomo predstavili nekatere elemente marketinškega spleta, pri čemer se bomo osredotočili zgolj na dimenzije sporočanja posameznega elementa.

\section{PRODUKT}

Podobno, kot vizualna zaznava pri komuniciranju med ljudmi predstavlja prvo zaznavo, velja tudi v procesu nakupovanja. Izmed vseh elementov marketinškega spleta ljudje morda res najprej zaznamo katerega od promocijskih sporočil. V trenutku, ko promocija povzroči interes, ljudi seveda zanimajo tudi ostali elementi marketinškega spleta. Osrednji predmet zanimanja potencialnega kupca postane produkt. Percepcija in čustva, ki jih spodbudi zaznava produkta, sta potreben pogoj za realizacijo nakupa. Če kupec ne bo ustrezno percepiral zaznanega produkta in če bo morda prišlo celo do pojava negativnih čustev, se zagotovo ne bo odločil za nakup.

Pod pojmom produkt razumemo vsak izdelek (v opredmeteni obliki) ali storitev (navadno v neopredmeteni obliki), ki jo je mogoče ponuditi trgu za vzbuditev pozornosti, za nakup, uporabo ali porabo, in ki lahko zadovolji željo ali potrebo.

Produkt z vidika komuniciranja proučujemo iz dveh gledišč:

- $\mathrm{z}$ vidika sporočanja potencialnemu kupcu;

- $\mathrm{z}$ vidika zadovoljstva obstoječega kupca. 
Produkt mora z nečem pritegniti pozornost. Elementov produkta je seveda več: kakovost, oblika, fizikalne dimenzije, barva ipd. Če proučujemo produkt zgolj z vidika marketinškega komuniciranja ugotovimo, da so elementi produkta zlasti:

- videz;

- ime produkta;

- značilnosti embalaže;

- značilnosti produkta ali storitve z vidika uporabnosti, kakovosti in dizajna.

Drug vidik sporočanja produkta je zadovoljstvo, ki ga produkt ob uporabi nudi kupcu. Kupec ob uporabi zaznava različne atribute produkta: ime, videz, delovanje, lastnosti, unikatnost, ipd. Velja, da se ob uporabnikovem zaznavanju produkta morajo pojavljati čustva zadovoljstva. Ponudnik mora zadovoljstvo priskrbeti in se izogniti nezadovoljstvu.

Organizacije za merjenje zadovoljstva kupcev uporabljajo predvsem naslednje metode:

- analizo reklamacij;

- sistem pritožb in predlogov;

- ankete o zadovoljstvu kupcev;

- namišljeno nakupovanje naših produktov oziroma produktov konkurence;

- analizo izgubljenih kupcev;

- drugo.

K oblikovanju produkta sodi tudi oblikovanje embalaže. Funkcije embalaže so:

- pritegniti pozornost;

- zaščita izdelka pred nečistočami;

- zaščita izdelka pred poškodbami;

- ohranjanje celovitosti izdelka, če je le-ta sestavljen iz več delov;

- drugo.

Zaznavanje atributov embalaže je zelo pomembno tako za odločitev o nakupu kot tudi za pojav čustev zadovoljstva ob uporabi. Zato mnogi ponudniki dobrin embalaži posvečajo še posebej velik pomen. Znan je primer proizvajalca prestižnih ur Panerai, ki uro proda v škatli iz češnjevega lesa.

Ime produkta ima z vidika sporočanja naslednje funkcije:

- služi prepoznavanju;

- sporoča dobre lastnosti;

- služi uporabi v namene promocije;

- drugo.

Mnoga podjetja želijo najti svojim produktom edinstvena imena. Poznani so primeri, ko podjetja imena že vnaprej pravno zaščitijo. 


\section{CENA}

Cena pomeni izraz denarne vrednosti izdelka na trgu. Prodajna cena seveda mora pokriti vse stroške razvoja, proizvodnje, promocije, distribucije, prodaje izdelkov, stroške davkov in morebitnih carin ter seveda zagotoviti dobiček. Vendar $\mathrm{v}$ tem kontekstu ne obravnavamo ekonomskih kriterijev za določanje cene, pač pa imamo $\mathrm{v}$ mislih oblikovanje cene kot elementu vplivanja na potrošnike.

Iz perspektive potencialnega kupca se moramo vprašati, kaj ob zaznavi cene razmišlja kupec. Kupec pred oziroma med nakupom razmišlja zlasti o naslednjem:

- Kakšne koristi mu bo prinesel nakup?

- Kakšna je kakovost produkta?

- Koliko je produkt uporaben?

- Kakšne osebne koristi mu bo nakup prinesel? (Brassington in Pettitt, 1997)

Kupec seveda razmišlja tudi o tem, kakšna je tista cena za produkt, ki ga bo zadovoljila in jo imel za primerno ali ugodno.

Razmišlja tudi o razmerju med ceno in kakovostjo. Tudi za ponudnika obstaja dilema, kako pozicionirati ceno glede na kakovost določenega produkta in glede na cene istovrstnih ali primerljivih produktov pri konkurenci. Možnosti pozicioniranja cene produkta glede na njegovo kakovost prikazuje slika 9.

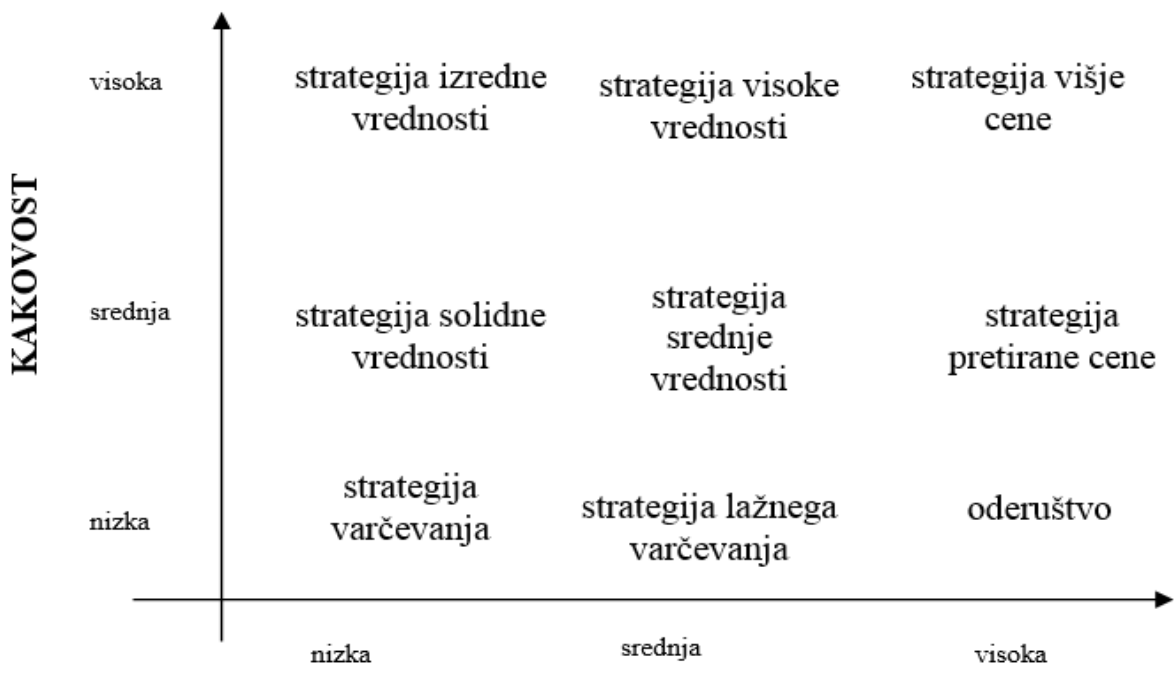

\section{CENA}

Slika 9: Možnosti pozicioniranja cene produkta glede na njegovo kakovost (Kotler, 1996). 
Pri oblikovanju cene določenih izdelkov (npr.: nekatere vrste avtomobilov, parfumov, tobačnih izdelkov, ur, tekstila, pohištva ipd.) je treba upoštevati, da obstaja tudi določen delež ljudi, ki bodo nek izdelek kupili za vsako ceno. Uporabnikove zaznave določenih vrst izdelkov oziroma blagovnih znamk sprožajo občutke užitka, prinašajo posebne osebne koristi, čustva ugodja in posebnega zadovoljstva, kar vse so uporabniki pripravljeni tudi plačati.

Proizvajalci in prodajalci pogosto uporabijo tako imenovano "razločevalno ceno". Gre za to, da isti izdelek prodajajo po različnih cenah, glede na:

- segment kupcev;

- ime izdelka (isti izdelki se lahko med seboj razlikuje zgolj po imenu, ne pa po obliki in funkciji);

- podobo izdelka (npr.: embalažo);

- lokacijo, kjer se prodaja;

- obdobje prodajanja.

Na dokončno oblikovanje cene vplivajo tudi nekateri psihološki fenomeni, kot so:

- Cena naj bi bila vedno zaokrožena na liho število.

- Cena ne sme biti drastično nižja od konkurence, saj to pri potencialnih kupcih povzroči pomisleke glede kakovosti.

- Mnogo kupcev vidi v trgovini številko npr: 199 bliže številki 100 kot 200; od tod "zaokrožanje«.

Znižanje cene ob razprodajh je povsem običajno. Ko kupec zazna razprodaje in popuste, to vpliva na pojav čustev. V času, ko ni obdobje razprodaj, pa si kupci nenadno znižanje cene lahko razlagajo kot:

- simbol, da je z izdelkom nekaj narobe in se zato slabo prodaja;

- simbol, da bo artikel zamenjan z novim modelom;

- simbol, da je podjetje v težavah;

- simbol slabše kakovosti izdelka.

Zvišanje cene pa ima včasih lahko celo pozitivne učinke.

\section{PRODAJA}

Prodaja že sama po sebi predstavlja komuniciranje. V tej knjigi smo že opisali korake prodaje, kot sta jih opisala Moncrief in Marshall (2005).

Potencialni kupec v klasični prodajalni zaznava:

- lokacijo prodajnega mesta;

- ime in zunanji videz prodajnega mesta; 
- videz prodajalca;

- videz, kompetence in zavzetost prodajalca;

- notranjo urejenost prodajalne;

- drugo.

Pomembne so tudi zaznave spletnega prodajnega mesta. Za kupca je ključno, da pred, med in po aktu prodaje zaznava vse tisto, kar mu vzbujajo zaupanje.

\section{LJUDJE}

Izvajalec vseh marketinških aktivnosti je človek. Ob tem hote ali nehote kaže svoj odnos do produkta katerega prodaja, do njegove cene in do organizacije kateri pripada. Človeško bitje s svojimi številnimi fenomeni je za kupca vir zaznav. Vidikov obravnave človeka kot enega od elementov marketinškega spleta je več. Izpostavili bomo le nekatere:

Potrošniška interakcija: človek je že od najbolj rosnih let nagnjen k posnemanju. Dojenček posnema svoje starše, ti pa soseda. Fenomen potrošniške interakcije izkorišča sodobni marketing, saj človeka dobesedno spodbuja k posnemanju potrošniških navad drugih. Gre za:

- posnemanje potrošniških navad najbližjih (npr.: sosedov, sodelavcev, sorodnikov);

- posnemanje javno znanih osebnosti.

Asociacije: uporaba točno določenih produktov, ki se pojavljajo v filmih, vzbuja asociacije na določene lastnosti (npr.: na romantiko, akcijo, ...).

Vrednote: uporaba točno določenih produktov, ki jih uporabljajo »ambasadorji« blagovnih znamk, simbolizira vrednote (npr.: fair-play, vztrajnost, delavnost, ...).

\section{PROCESIRANJE}

Procesiranje kot element marketinškega spleta pomeni:

- način izvajanja vseh marketinških dejavnosti;

- razvojno funkcijo;

- družbeno-odgovorno ravnanje organizacije.

V zvezi s procesiranjem potencialne kupce zanima:

- ekološka varnost proizvodnje;

- ustreznost izdelka standardom;

- kompatibilnost z drugimi izdelki;

- socialno pravično ravnanje;

- ipd. 
Med procesom marketinškega komuniciranja je potencialne kupce treba o vseh naštetih elementih na nek način informirati.

\section{FIZIČNI DOKAZI}

Fizični dokazi imajo lahko dvojno funkcijo;

- Opozarjajo, da nekaj sploh obstaja.

- So dokaz uspešnosti, privlačnosti ipd.

Prikazovanje fizičnih dokazov kot elementa marketinškega spleta se pojavlja vsepovsod; od spleta, literature, radia, televizije, filma, športa in večine drugih oblik življenja. Snovalec marketinškega spleta se lahko odloči za:

- očitno uporabo fizičnih dokazov;

- obrobno uporabo fizičnih dokazov.

Očitna uporaba fizičnih dokazov je vse tisto, kar neposredno opominja na sam obstoj produkta oziroma organizacije. To je marsikaj: od poslovnih prostorov, parkirišča, delovnih oblačil osebja, zastav, pa do najmanjših drobnih malenkosti. V zvezi s fizičnimi dokazi se zelo pogosto omenja celostna podoba.

Celostna (grafična) podoba podjetja "dokazuje" sam obstoj organizacije. Celostno podobo navadno sestavljajo naslednja obeležja: ime firme, znak oziroma logotip, glave in noge obrazcev in tiskovin, značilne barve, pisave, mape, rokovniki, pisala, žigi, kuverte ipd.

Obrobna uporaba fizičnih dokazov predstavlja pojavljanje produkta oziroma blagovne znamke na spletu, v filmih, na športnih prireditvah, v knjigah in drugje. Bistveno je, da se produkt ali blagovna znamka pojavi $\mathrm{v}$ širšem kontekstu prikazovanja uspešnosti, privlačnosti ali mode. Produkt ali blagovno znamko v tem kontekstu ljudje zaznajo, zaznava pa spodbudi pojav čustev. Tipičen primer je James Bond, ki vozi avto Aston Martin, pije Martini in nosi ročno uro Omega. 


\section{PROMOCIJSKI SPLET}

Promocijski splet je eden od elementov marketinškega spleta. Philip Kotler (1996) pravi, da promocijski splet sestavljajo:

- oglaševanje;

- odnosi z javnostmi (tiskovna sporočila, govori, seminarji, letna poročila, dobrodelna darila, objave, odnosi z lokalnim okoljem, lobiranje, dogodki, itd.);

- pospeševanje prodaje (nagradna tekmovanja, igre, žrebanja, darila, vzorci, sejmi, razstave, predstavitve, kuponi, znižanja, ugodni krediti, prodaja "staro za novo", vezana prodaja itd.);

- osebna prodaja (prodajne predstavitve, sejmi, itd.);

- neposredno trženje (katalogi, neposredna pošta, trženje po telefonu, elektronsko poslovanje, TV prodaja, itd.).

Promocijski splet se je v zgodovini marketinga pojavil zelo zgodaj. Klasična oblika promocije je oglaševanje.

Oglaševanje je plačana oblika neosebne promocije, poslane prek masovnih medijev (Brassington in Pettitt, 1997). Je enosmerno komuniciranje, ker gre komunikacijski tok le $\mathrm{v}$ eno smer (od oglaševalca $\mathrm{k}$ sprejemniku). Mediji $\mathrm{v}$ imenu nekega ponudnika (oglaševalca) pošiljajo sporočila.

Posebna oblika oglaševanja je sponzoriranje. Sponzorstvo je oblika oglaševalskega sporočanja. Gre za to, da sponzor zakupi del pozornosti, ki naj bi jo pri ciljnih skupinah sponzorja dosegel sponzoriranec.

Po podatkih American Advertising Museuma v Portlandu naj bi časopis "The Boston Newsletter" v Bostonu že leta 1704 objavljal plačane oglase. Leta 1807 pa je neko podjetje v New Yorku oglaševalo pohištvo. Poznani so tudi plakati, ki so oglaševali šivalne stroje Singer iz leta 1850. Ohranili pa so se plakati, ki so oglaševali keramično straniščno školjko s kotličkom za izplakovanje (iz leta 1890) in zadrgo (leta 1905). Kmalu po prvi svetovni vojni se je začelo oglaševanje avtomobilov in drugih izdelkov široke potrošnje. Eden prvih oglaševalcev avtomobilov je bilo podjetje Ford, ki je leta 1908 oglaševalo model $T$. Oglaševanje na televiziji se je začelo po letu 1945. Tako je poznano, da je npr.: oglas za britvice Gillete leta 1946 videlo 150.000 ljudi.

Promocija sama po sebi izvira iz temeljev filozofije marketinga. Bistvo filozofije marketinga je v zagotavljanju zadovoljstva kupca. V tem kontekstu ima promocija naslednje funkcije:

- seznanjanje, da nek izdelek ali storitev sploh obstaja;

- obveščanje o lastnostih izdelka; 
- poudarjanje oziroma prepričevanje potencialnih kupcev o pozitivnih lastnostih izdelka oziroma storitve.

Sčasoma je dobila še druge funkcije:

- primerjanje pozitivnih karakteristik izdelka $\mathrm{V}$ primerjavi $\mathrm{z}$ negativnimi karakteristikami konkurenčnega izdelka;

- sugeriranje vplivnega (poznanega) posameznika;

- druge funkcije.

Mnoge prakse marketinga so skozi desetletja zašle v smer, ki ni skladna z bistvom filozofije marketinga. Marsikdaj je postala način prepričevanja kupca.

Pri oglaševanju je bolj kot za zagotavljanje zadovoljstva kupca mnogokrat šlo za načrtno delovanje na človekovo psiho $\mathrm{z}$ namenom ustvariti čim intenzivnejšo in dolgotrajno pripravljenost za nakup(ovanje) izdelka ali storitve. Edini namen vsakega oglaševanja (produkta ali storitve) je mnogokrat postal zgolj povečati obseg prodaje. Oglaševanje je postalo usmerjeno zgolj na psihološke dejavnike, ki vplivajo na nakup.

Zaradi tega se je dramatično povečal obseg oglaševanja. Stroškov oglaševanja nikoli ne bomo mogli natančno ugotoviti, dejstvo pa je, da se na svetu potroši za oglaševanje več sto milijard dolarjev letno. Oglaševanje je vplivalo tako na človeka kot posameznika, kot tudi na družbo kot celoto.

Vendar so potrošniki z oglasi skozi desetletja postali zasičeni. Priča smo preveliki kompleksnosti in pogostosti oglaševanja. Vse to ugotavljajo tudi teoretiki in praktiki marketinga. Chaney (2009) tako pravi:

- Ljudje se že dolgo izogibajo oglasom.

- Prišlo je do zelo velike fragmentacije medijev.

- Po drugi strani je pritisk oglaševalcev na potrošnike z oglasi vedno večji.

- Oglasi postajajo zelo fokusirani v ciljne skupine, stroške za oglase pa oglaševalci želijo nižati.

- Podjetja se obnašajo odgovorneje, kot kadarkoli prej.

- Potrošniki nakupov več ne opravljajo v tolikšni meri na podlagi vpliva oglasov, pač pa na podlagi zaupanja.

Kljub vsemu navedenemu, oglaševanje ni izumrlo. Koristi ako organizacijam, kot potrošnikom. Za organizacije je oglaševanje potrebno iz zelo enostavnega razloga, ker morajo biti vidne.

Za potrošnike pa oglaševanje kljub vsemu še vedno ostaja vir informacij. Po zaznavi izjemno velikega števila oglasov ima vsak potrošnik na voljo številne vire za kritično analizo prejetih sporočil. 
Oglaševanje torej ostaja pomembna sestavina komuniciranja organizacij z okoljem, zato si še vedno zasluži pozorno obravnavo. 
PoSLOVNO KOMUNICIRANJE

Marketinško komuniciranje 


\section{OGLAŠEVANJE}

Da uspešno oglaševanje je pomembno:

- posvetiti primerno pozornost izvajanju funkcij procesa managementa;

- skrbno izvesti vse faze oglaševanja.

Management mora poskrbeti predvsem za planiranje, organiziranje in kontrolo. Zaradi same narave oglaševanja je najprej treba definirati cilje oglaševanja. Da bi dosegli cilje, je potrebno planiranje. Planirati pomeni:

- opredeliti dejavnosti, katere je treba opraviti;

- določiti nosilce dejavnosti;

- časovno opredeliti trajanje dejavnosti in določiti roke dokončanja;

- opredeliti potrebne vire.

Oglaševanje je aktivnost, kjer se pojavljajo vsebinsko zelo različne vsebine dela. Vsebina dela kreatorja oglasov je popolnoma drugačno od dela specialista, ki skrbi za zanesljivo delovanje strežnikov. Opravila v zvezi z oglaševanjem je zato potrebno organizirati. Treba je razdeliti vloge in poskrbeti za medsebojno koordinacijo.

Zaradi visokih stroškov oglaševanja je treba izvajati tudi funkcijo kontrole.

Faze izvedbe oglaševanja so:

- definicija namena oziroma ciljev oglaševanja;

- določitev proračuna za oglaševanje;

- izbor občinstva in definicija ciljne skupine;

- izbira medija;

- kreiranje sporočila,

- določitev dinamike oglaševanja;

- izdelava media plana,

- vrednotenje učinkov.

\section{DEFINICIJA NAMENA OZIROMA CILJEV OGLAŠEVANJA}

Kot smo v tej knjigi že pojasnili, je namen oglaševanja:

- po eni strani zagotoviti zadovoljstvo potrošnika;

- po drugi strani prepričati potrošnika $\mathrm{v}$ nakup. 


\section{DOLOČITEV PRORAČUNA ZA OGLAŠEVANJE}

Pred vsako oglaševalsko akcijo je potrebno določiti proračun za izvedbo.

Stroške oglaševanja je mogoče razdeliti na:

- stroške dela zaposlenih;

- stroške storitev za pripravo gradiva za oglaševanje;

- stroške nabave materiala;

- stroške oglaševanja v medijih.

Stroški storitev za pripravo gradiva so zelo raznovrstni: od plačil kreatorjem oglasa, do plačila stroškov tehnične izvedbe in morebitnega odkupa avtorskih pravic.

Cena samega oglaševanja na spletu, radiu in na televiziji je sorazmerna $\mathrm{z}$ dvema dejavnikoma:

- $\mathrm{s}$ trajanjem oglaševalske kampanje;

- s številom objav;

- z vsakokratnim številom vzpostavljenih kontaktov.

"Isolated 30" je referenčna vrednost za izračun cene oglaševanja na radiju in na televiziji. To je sporočilo na radiu ali na televiziji $\mathrm{v}$ trajanju 30 sekund. $\mathrm{V}$ tiskanih medijih se namesto "isolated 30" za izračun cene upošteva stran v mediju. Pri spletnem oglaševanju se kot merilo števila kontaktov upošteva število prikazov oglasa (npr. »bannerja«). Če pa gre za oglas s povezavo na spletno stran oglaševalca, se upošteva število »klikov«.

Absolutni zneski cene oglaševanja $\mathrm{v}$ posameznih medijih istega ali različnega tipa nikakor niso primerljivi. Za realno primerjanje cen oglaševanja $\mathrm{v}$ posameznih medijih poskušamo ugotoviti ceno na 1000 kontaktov

Poleg naštetega se za izračun cene oglaševanja upoštevajo še drugi elementi, kot:

- velikost oglasa;

- zahtevnost tehnične realizacije oglasa;

- ekskluzivnost publike medija;

- prestižnost medija;

- ponudba in povpraševanje po določenem terminu oz. mestu

- drugo.

Mediji oglaševalskim agencijam ob zakupu medijskega prostora ponujajo popuste oziroma provizije. Oglaševanje prek agencij zato za naročnika lahko predstavlja nižji strošek. 


\section{IDENTIFIKACIJA CILJNE SKUPINE}

Za uspešno oglaševanje moramo ugotoviti, komu naj bi bilo namenjeno. Običajno je oglaševanje namenjeno ciljni skupini. Ciljna skupina so dejanski ali potencialni kupci nekega produkta. Oglaševanje je lahko namenjeno tudi najširšemu občinstvu. Občinstvo so vsi ljudje, ki zaznajo neko sporočilo.

Poznavanje ciljne skupine je pomembno iz vsaj dveh razlogov:

- Samo sporočilo, s katerim oglaševalec pristopa k občinstvu, mora biti kreirano značilnostim ciljne skupine primerno. Brez dobrega poznavanja značilnosti ciljne skupine to ni mogoče.

- Oglaševalec mora poznati strukturo občinstva posameznega medija v katerem namerava oglaševati. Le tako bo ugotovil, ali obstaja verjetnost, da bo njegovo sporočilo pritegnilo sedanje in potencialne bodoče poslovne partnerje-torej tudi ciljne skupine.

Struktura občinstva posameznega medija je bistveni element med procesom odločanja o tem, ali naj do oglaševanja v konkretni medij sploh pride. Za oglaševalca je pomembno, da je število "sprejemnikov" njegovega sporočila:

- po eni strani čim večje,

- po drugi strani pa morajo značilnosti (demografske, socialne, ...) ustrezati njegovim zahtevam.

Določitev ciljne skupine je proces selekcije enega ali več segmentov za pristop k oglaševanju. Atributi ciljne skupine so:

- plačilna oziroma kreditna sposbnost;

- starost;

- spol;

- izobrazba;

- pripadnost družbenemu razredu;

- pripadnost subkulturni skupini;

- pripadnost verski skupini oziroma izražanje verskega prepričanja;

- prostočasni interesi;

- potrošniški stil;

- drugo.

\section{IZBIRA MEDIJA}

Spremljanje medijev v življenju ni človekovo najpomembnejše opravilo. Medije spremljamo v prostem času ali kar vzporedno med svojimi drugimi aktivnostmi. Ljudje nekatere medije spremljamo površno, druge zelo podrobno. Pričakovanja ljudi do različnih medijev so raznovrstna. Navadno ljudje spremljamo tiste medije, ki nam 
ponujajo užitke, razvedrilo in zadovoljstvo. Take medije spremljamo bolj pozorno. Bolj smo kritični do tistih medijev, ki jih moramo plačati.

Temeljni kriterij pri izbiri medija za oglaševanje je zaupanje ciljne skupine v medij. Izbrani medij morajo ciljne skupine šteti za kredibilen vir informacij. Pri odločanju o izbiri medija za oglaševanje moramo ugotoviti:

- Ali je z oglaševanjem v konkretni medij mogoče posredovati sporočilo želeni ciljni skupini?

- Ali obseg spremljanja medija (npr.: obisk spletnih strani, branost, gledanost, poslušanost) zadosti našim potrebam?

- Ali v mediju lahko doseženo želeno frekvenco ponavljanja?

- Kakšna je cena oglaševanja?

- Kako naj bi bilo oblikovano oglasno sporočilo v konkretnem mediju (npr.: interaktivna povezava, besedilo, fotografija, opis, gibajoča se slika, video, zvok)?

- Ali je konkreten medij primeren za osnovno oglaševanje ali tudi za "podporo"?

- Ali je oddan oglas mogoče spremljati enkrat ali večkrat (ali je sporočilo minljivo, ali trajno)?

- Ali je oglaševanje mogoče prilagoditi lokalnim posebnostim?

- Ali vsebina oglasa sodi v vsebinski kontekst medija?

Seveda ima vsak oglaševalec objektivne in subjektivne kriterije.

\section{KREIRANJE SPOROČILA}

Vsebina sporočila je odvisna od izbrane strategije promocije. Devetak (1999) tako opisuje pet tipov strategije promocije:

- vzbujanje pozornosti;

- dopolnjevanje že znanih informacij;

- predstavljanje prednosti pred konkurenco;

- opominjanje;

- apeliranje na sklenitev posla.

Strategijo izberemo glede na to, kakšne učinke promocije oziroma oglaševanja pričakujemo. Vsak oglaševalec pričakuje, da se bodo pri ljudeh po zaznavi oglasnega sporočila pojavili učinki. Navedli smo že, da gre za percepcijo, kognicijo in pojav čustev. Kreiranje sporočila je zato eno najzahtevnejših opravil v zvezi z oglaševanjem. Prav to fazo navadno prepustimo specialistom.

Pred kreiranjem sporočila pa je vendarle dobro razmisliti o naslednjem:

- Kakšno sporočilo je primerno za ciljno skupino, kateri je namenjeno. 
- Ali bo vsebina sporočila primerna (z vsebinskega vidika) za oddajo ob času, v katerem nameravamo izvajati oglaševalsko akcijo.

- Ali bo vsebina sporočila primerna (z vsebinskega vidika) za tip medija, v katerem nameravamo izvajati oglaševalsko akcijo.

- Ali se je podobno sporočilo že pojavljalo v bližnji preteklosti.

Tudi za oglasna sporočila velja upoštevati prvine uspešnega prepričevanja, ki so: etos, logos in patos. Če oglasno sporočilo vsebuje nekaj, kar doslej ni bilo znano, obstaja večja verjetnost njegove zaznave. Prav tako je verjetnost zaznave večja, če posamezni oglas ali oglaševalska kampanja kot celota vsebuje »zgodbo«. Ni pa pravila o tem, ali je bolje, če je predmet zaznave več elementov izdelka ali samo eden.

\section{DINAMIKA OGLAŠEVANJA}

Dinamika oglaševanja posameznega izdelka ali storitve je odvisna od:

- trajanja procesa odločanja o nakupu;

- faze v njegovem življenjskem ciklusu;

- zasnove oglaševalske akcije;

- razpoložljivih sredstev za oglaševanje.

Vsak prodajalec si seveda želi hipnih odločitev potrošnika o nakupu. Vendar pa se ljudje o nakupih dražjih dobrin praviloma odločajo po premisleku. Omenili smo že AIDA model odločanja. Proces odločanja o nakupu traja neko časovno obdobje. Preden se človek odloči za nakup avtomobila, si ogleda različne možnosti nakupa. Podobno velja za nakup pohištva, gospodinjskih aparatov, počitniških paketov in številnih drugih dobrin. Dijaki se o vpisu na fakulteto odločajo več mesecev. Ljudje pred nakupom iščejo informacije pri zasebnih in pri poslovnih virih.

Ponudnik dobrin mora zato spoznati:

- dinamiko prodaje skozi različna sezonska obdobja,

- čas trajanje odločanja o nakupu dobrine, katero ponuja;

- vsebine zanimanja ljudi pred nakupom.

Temu mora prilagoditi dinamiko in vsebino oglaševanja.

Življenjski ciklus izdelka oziroma storitve je prikaz odvisnosti obsega prodaje od časa, ko je dotični produkt že na trgu. Prikazan je na sliki 10.

Črtkana črta prikazuje, kako se v odvisnosti od časa spreminja obseg prodaje, polna črta pa, obseg oglaševanja.

Ko na trg uvajamo nov produkt, je nujen večji obseg oglaševanja. Ljudje morajo zaznati, da nov produkt sploh obstaja. Po nekem obdobju se v ljudeh izoblikuje spoznanje o obstoju novega produkta, zato se obseg oglaševanja lahko zmanjša. 
Sčasoma na trg pridejo podobni izdelki konkurence, pojavijo se tudi novi proizvodi oziroma substituti. Eden od načinov za dvig obsega prodaje $\mathrm{v}$ takih okoliščinah je tudi oglaševanje. $\mathrm{V}$ tem primeru ima oglaševanje funkcijo »opominjanja« da izdelek na trgu še vedno obstaja.

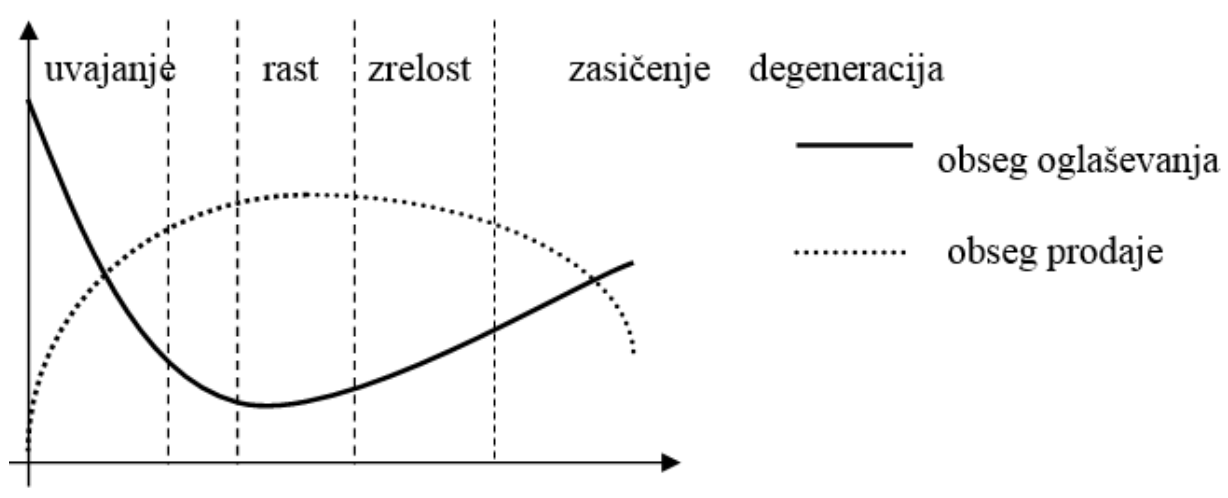

čas

\section{SLIKA 10: Odvisnost oglaševanja od življenjskega ciklusa izdelka oziroma storitve. ${ }^{26}$}

Oglaševalska kampanja lahko poteka v enem mediju, lahko hkrati v več medijih, lahko pa je sestavljena iz več faz. Gre za sočasno oglaševanje v medijih različnega tipa, ki si med seboj niso konkurenčni, so pa usmerjeni $\mathrm{k}$ isti ciljni skupini.

Dinamika oglaševanja $\mathrm{v}$ posameznih medijih se pogosto opredeli že $\mathrm{v}$ fazi kreiranja sporočila. Dinamika oglaševanja $\mathrm{v}$ posameznih medijih se planira vnaprej $\mathrm{v}$ tako imenovanem "media-planu". Glede na dinamiko oglaševanja poznamo različne strategije oglaševanja. Dve od njih sta prikazani na sliki 11.

${ }^{26}$ Življenjski ciklus izdelka prikazan po: Devetak, 1999. 

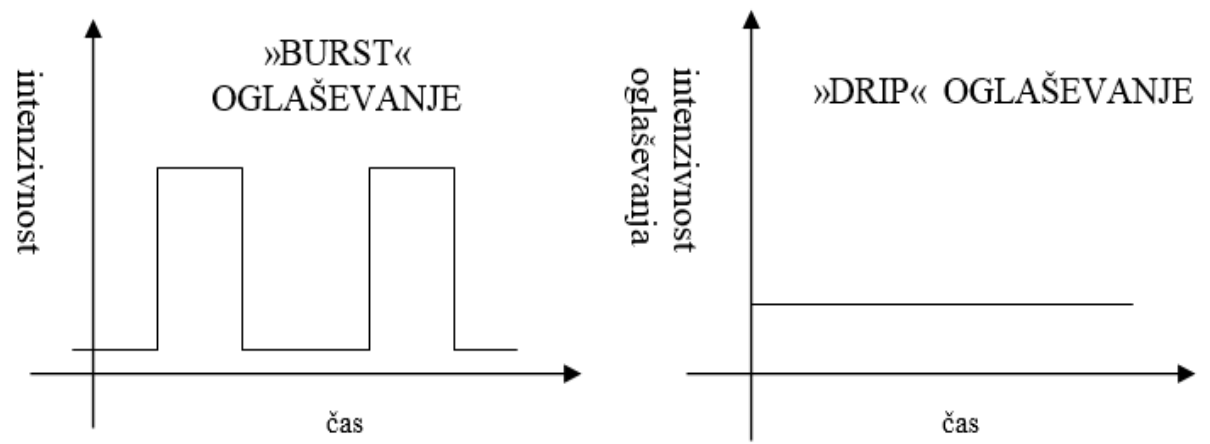

SLIKA 11: Dva osnovna tipa strategij oglaševanja glede na dinamiko. ${ }^{27}$

TABELA 3: Primer media plana za en teden.

\begin{tabular}{|l|l|l|l|l|}
\hline $\begin{array}{l}\text { DAN/MEDI } \\
\text { J }\end{array}$ & RADIO A & RADIO B & TV & ČASOPIS \\
\hline PON & spot 1 ob 6,40 & - & spot 2 ob 19,25 & - \\
\hline TOR & spot 1 ob 6,40 & - & spot 2 ob 19,25 & oglas $1 / 4$ strani \\
\hline SRE & spot 1 ob 6,40 & - & spot 2 ob 19,25 & - \\
\hline ČET & spot 1 ob 6,40 & - & spot 2 ob 19,25 & - \\
\hline PET & spot 1 ob 6,40 & - & spot 2 ob 19,25 & oglas $1 / 4$ strani \\
\hline SOB & spot 1 ob 6,40 & spot 1 ob 11,55 & - & - \\
\hline NED & - & spot 1 ob 11,55 & - & - \\
\hline
\end{tabular}

Media plan opredeljuje termine, pojavne oblike in kanale oglaševanja. Je izhodišče za planiranje stroškov oglaševanja. Primer je prikazan v tabeli 3 .

Sissors (1993) pravi, da na dinamiko oglaševanja poleg že naštetih dejavnikov vplivajo tudi drugi:

- Število prebivalcev oziroma družin na določenem geografskem območju;

- efektivna kupna moč, katero opredeljujejo: življenjska raven, potrošniške navade, družinski prejemki, varčevanje, možnost kreditiranja nakupov in nagnjenja k nakupom;

- podatki o prodaji;

- sezona prodaje;

- drugo

Vsak oglaševalec se pred izvedbo oglaševanja mora vprašati, če na dinamiko oglaševanja želi vplivati ali ne. Treba se je zavedati, da se v primeru, kadar izvedbo oglaševalske kampanje prepustimo zunanjemu izvajalcu (npr.: oglaševalski agenciji) lahko zgodi, da naročnik na dinamiko ne bo imel vpliva. Oglaševalske agencije namreč pogosto zakupijo

${ }^{27}$ Kotler navaja več tipov strategij. Podrobnejšo in obširnejšo obrazložitev strategij oglaševanja glej v: Kotler, 1996. 
"pakete« oglaševalsega prostora v medijih. Interes jim je lahko zgolj zapolniti zakupljen prostor.

\section{VREDNOTENJE UČINKOV}

Ob samem oglaševanju je zelo pomembno izvajati funkcijo kontrole. Med procesom oglaševanja z naročnikom navadno sodelujejo številni partnerji (od agencij, kreatorjev oglasov, medijskih planerjev in drugih). Zato je funkcija kontrole precej kompleksna.

Oglaševalci iz svojega vidika spremljajo gospodarnost oglaševanja $v$ posameznem mediju. Za vsako oglaševanje je treba izmeriti rezultate. Neposredni rezultat oglaševanja bi moral biti večji obseg prodaje. Vendar se moramo zavedati, da na obseg prodaje ne vpliva zgolj oglaševanje, pač pa tudi drugi dejavniki.

Dostikrat z oglaševanjem skušamo doseči tudi druge cilje, ki le posredno pripomorejo k povečanju obsega prodaje. Ti cilji so:

- povečati število obiskovalcev spletnih strani;

- doseči geografsko razpršenost obiskovalcev;

- podaljšati čas zadržanja obiskovalcev na spletni strani;

- drugo. 


\section{DIGITALNI MARKETING}

Digitalni marketing je razvijajoč koncept, zato obstajajo različne definicije tega pojma. Wymbs (2011) pravi, da je digitalni marketing uporaba digitalnih tehnologij za oblikovanje integriranega, ciljno usmerjenega in merljivega komuniciranja, ki podjetju pomaga pridobiti in obdržati stranke in z njimi graditi globlje odnose.

Digitalni marketing vključuje uporabo digitalnih tehnologij: svetovnega spleta, elektronske pošte, podatkovnih baz, mobilnih omrežij, WI-FI omrežij in digitalne televizije.

Namen digitalnega marketinga je, da se $\mathrm{z}$ digitalnimi tehnologijami podpre interaktivne in ne-interaktivne dejavnosti podjetja, katerih cilj je dobičkonosno pridobivanje in zadržanje strank.

Ključna razlika med digitalnim marketingom in tradicionalnimi oblikami marketinga je, da digitalne tehnologije olajšajo vzpostavitev odnosov med kupcem in podjetjem. Digitalne tehnologije same po sebi omogočajo sledljivost in merjenje učinkov. Omogočajo tudi mnogo bolj usmerjeno komuniciranje.

Wymbs (2011) digitalne tehnologije, ki se uporabljajo v digitalnem marketingu deli na vidik potrošnika in na vidik organizacij, ki ponujajo dobrine.

Digitalne tehnologije, ki jih v digitalnem marketingu uporabljajo potrošniki so:

- socialna omrežja;

- iskalniki;

- tehnologije elektronskega poslovanja (npr.: elektronsko bančništvo, spletno nakupovanje, idr.);

- elektronska pošta;

- različne aplikacije.

Digitalne tehnologije, ki jih uporabljajo ponudniki dobrin so:

- »digitalno« oglaševanje;

- raziskovanje; trga;

- elektronska pošta;

- elektronsko dizajniranje produktov;

- iskalniki;

- optimizacije spletnih strani;

- razvoj komuniciranja prek digitalnih medijev;

- integrirano elektronsko poslovanje. 
Digitalni marketing je torej skupno ime za več zelo različnih tehnologij in aktivnosti, ki jih tehnologije omogočajo organizaciji. Lahko so med seboj povezane, lahko pa tudi ne.

Izhajajoč iz temeljne filozofije marketinga, tudi pri izvajanju digitalnega marketinga temeljni vprašanji ostajata:

- Ali je stranka zadovoljna?

- Ali podjetje upraviči namen svojega obstoja?

Pojav digitalnega marketinga je nedvomno razširil kategorije oziroma področja, na katera se nanaša zadovoljstvo strank. Področje zadovoljstva strank se namreč ne nanaša več zgolj na lastnosti produkta, na ceno, skratka na elemente, kot jih poznamo pod skupnim imenom »marketinški splet«. Gre za širše dimenzije, ki presegajo tradicionalno pojmovanje marketinškega spleta.

Za potrošnike pojav digitalnega marketinga pomeni nov, doslej neobstoječ način:

- pridobivanja informacij pred nakupom: o lastnostih produktov, o ceni, o dobavljivosti, idr.;

- vzpostavitve lastnih predstav o lastnih potrebah, željah in pričakovanjih;

- primerjanja ponudb različnih dobaviteljev;

- pridobivanje ocen in izkušenj od že obstoječih kupcev;

- izvedbe samega nakupa (npr. nakupovanje preko spleta);

- možnosti stornacije nakupa;

- zadovoljevanja postprodajnih potreb, kot npr.: navodila za uporabo izdelkov, naročanje na servis, ipd.;

- izmenjave mnenj s sedanjimi in bodočimi uporabniki izdelkov;

- oblikovanja lastnih kriterijev zaupanja.

Da bi koncept digitalnega marketinga deloval, je ključno, da:

- ponudnik poleg zadovoljstva s tradicionalnimi elementi marketinškega spleta zagotovi tudi zadovoljstvo stranke z zgoraj naštetimi elementi;

- je zagotovljena ustrezna varnost, tako za ponudnika, kot za stranko;

- se vzpostavi zaupanje med ponudnikom in stranko.

Zadovoljstvo stranke ponudnik lahko zagotovi tako, da:

- planira vse dejavnosti, katere kot ponudnik dobrine mora opraviti pred prodajo, med prodajo in po prodaji, da bi bil potrošnik zadovoljen;

- temu primerno organizira svoje notranje procese;

- uporablja ustrezno strojno in programsko opremo;

- vzpostavi ustrezno notranjo organizacijsko kulturo;

- dela opravljajo kompetentni in zavzeti zaposleni;

- zagotovi varnost, ki jo potrošnik pričakuje. 
Zaupanje strank do organizacije je v prvi vrsti odvisno od tega, kako organizacija dojema:

- namen svojega obstoja in

- filozofijo marketinga,

ter kako to dvoje percepirajo potrošniki.

Kot smo že večkrat omenili, organizacije namen svojega obstoja lahko dojemajo zgolj kot ustvarjanje dobička, lahko pa tudi širše. Filozofijo marketinga organizacije lahko dojemajo zgolj kot način za ustvarjanje dobička, lahko pa poleg tega tudi kot način za zagotavljanje zadovoljstva potrošnikov. Izhajajoč iz tega, digitalni marketing za organizacijo lahko predstavlja:

- Zgolj nov kanal za posredovanje obstoječih vsebin komuniciranja potrošnikom v smislu še bolj agresivnega spodbujanja k nakupu, kot je to bilo že pred pojavo, digitalnega marketinga.

- Nov koncept poslovanja, kateremu se prilagodijo notranji procesi, uporabljena tehnologija, kadrovska struktura in organizacijska kultura.

Kjer je digitalni marketing nov način zagotavljanja zadovoljstva strank, predstavlja nove elemente marketinškega spleta, ki jih prej ni bilo. Tak primer je npr. interaktivno konfiguriranje produkta.

Da bi podjetja digitalni marketing lahko udejanila, potrebujejo zaposlene, ki imajo povsem nova znanja. Wymbs (2011) izpostavlja naslednja vsebinska področja:

- obnašanje potrošnikov v digitalnem marketingu;

- interaktivni marketing;

- marketing preko družbenih omrežij;

- tehnologije elektronskega poslovanja;

- management mednarodnih oskrbovalnih verig;

- nacionalne in mednarodne zakonodaje o spletnem poslovanju;

- idr.

Razvoj digitalnega marketinga ni zgolj pojav, ki zadeva podjetja. Zadeva širšo družbo. Prihaja do sprememb v deležu trgovine v BDP posameznih držav. S pojavom digitalnega marketinga trg bolj kot kadarkoli doslej postaja globalen. 
Marketinško komuniciranje 
PoSLOVNO KOMUNICIRANJE

M. Ferjan

\section{ODNOSI Z JAVNOSTMI}





\section{OPREDELITEV JAVNOSTI}

Skozi stoletja se je izoblikovalo več pojmovanj javnosti. Beseda javnost lahko pomeni:

- organizirano ali neorganizirano skupnost ljudi, ki je udeležena pri reševanju družbenih vprašanj;

- obliko izvajanja dejavnosti, ki je pomembna za družbo (zdravstvo, šolstvo, socialno varstvo);

- vsebino, način in obseg participacije pri upravljanju in vodenju procesov, pomembnih za družbo;

- količino posredovanih podatkov o neki zadevi;

- javno mnenje kot enako mnenje pomembno velikega deleža populacije o neki zadevi.

- javno sfero kot socialno omrežje za prenos informacij in stališč;

Javno sfero lahko opišemo kot komunikacijsko mrežo za prenos informacij in stališč. Za Habermasa (1997) je javna sfera socialni pojav, tako kot javni ukrep, akter, združenje ali skupnost. Vendar javna sfera ni institucija in ne organizacija.

Splichal (1999) meni, da bi javno sfero metaforično lahko opredelili kot mnenjski trg. Calhoun (1992) navaja, da sta osrednji temi demokratične javne sfere država in gospodarstvo.

Javno mnenje pa je mnenje večine ljudi oziroma prevladujoče mnenje o neki zadevi. Lahko ga opredelimo kot:

- $\quad$ stališča ljudi o neki zadevi;

- videnje lastnosti oziroma stanja nečesa glede na lastno znanje;

- pozitiven oziroma negativen odnos do nečesa;

- kriterij ljudi za presojanje nečesa.

Ob obravnavi javnosti organizacij imamo največkrat v mislih ljudi iz okolja, to je zunanje javnosti Nobena organizacija ni izolirana od okolja. Aldrich (1979) poudarja tri glavne predpostavke o odnosu organizacije z okoljem:

- Obstajajo tudi cilji organizacije, katere organizaciji narekuje okolje.

- Meje organizacije niso fiksne.

- Organizacije niso enakomerno prilagodljive na vsako okolje.

V vsaki organizaciji je treba neprestano ocenjevati oziroma preverjati »ustrezen odnos« do zunanjega okolja. 
Ne smemo pa pozabiti tudi na obstoj notranjih javnosti. V vsaki organizaciji namreč obstajajo tudi te. Na dejstvo, da so notranje javnosti izjemno pomembne za organizacijo, opozarjajo številni avtorji (glej npr. Jefkins, 1998, Harrison, 1995, idr.). Tudi ljudje, ki so zaposleni v organizaciji želijo:

- biti soudeležene pri reševanju vprašanj organizacije;

- biti enakopravno udeleženi pri distribuciji ugodnosti;

- participirati pri vodenju in upravljanju;

- biti obveščeni o zadevah, ki so zanje pomembne;

- imeti svoje mnenje o zadevah organizacije;

- izmenjevati svoje mnenje $\mathrm{z}$ drugimi.

Zaposleni imajo družinske člane, sorodnike in prijatelje. Imajo tudi stike s poslovnimi partnerji in strankami. Zato je notranje komuniciranje zelo pomembno področje.

V nadaljnji obravnavi odnosov z javnostmi bomo izhajali iz definicije javnosti, ki pravi, da je javnost skupina ljudi, ki dejansko ali potencialno lahko vpliva na poslovanje organizacije.

Kot pravita Hunt in Grunig (1994) je javnost katerakoli skupina ljudi, ki se dejansko ali potencialno zanima oziroma vpliva na sposobnost podjetja, da doseže svoje cilje. Javnosti lahko tudi vplivajo na poslovanje organizacije. Obstaja celo možnost, da organizacija zaradi vpliva javnosti preneha obstajati. Odnosi z javnostmi imajo zato tudi ekonomsko ozadje.

Javnost lahko pomeni ljudi v celoti, lahko pa posamezne skupine ljudi z zelo različnimi demografskimi, socialnimi in drugimi karakteristikami. Javnosti so lahko formalno organizirane, lahko pa tudi ne. Povezuje jih skupen interes (npr.: okolje varstveni, politični, ekonomski, itd.).

Teorija javnosti, kot jo razumeta Hunt in Grunig (1994) ima dve spremenljivki:

- prepoznavanje problema;

- stopnjo vpletenosti.

Za javnost je značilna vsaj ena od naštetih karakteristik. Javnost organizacije pa so lahko tudi ljudje, ki jih organizacija ne vpleta v svoje ravnanje, niti jim ne povzroči nobenega problema. Dovolj je lahko že to, da imajo neko mnenje, stališče ali vrednoto in jih nič ne ovira, da ne bi bili javnost. Če za skupino ljudi ni značilna nobena od teh karakteristik, potem niso javnost organizacije.

Ker je problemov, katere s svojim ravnanjem povzroča organizacija, lahko več in ker organizacija različne skupine ljudi lahko vpleta $v$ svoje ravnanje na različne načine, je javnosti organizacije lahko več. Zato govorimo o javnostih (v množini). 
Bistveni kriterij pri razčlenjevanju posameznikov oziroma delov populacije v javnosti je v tem, da so ti posamezniki v neki relaciji z organizacijo. Demografski, socialni ali geografski kriterij ni bistven. Bolj verjetno, da bodo javnosti dejavne je, če:

- bodo ljudje, ki javnosti sestavljajo opazili, da jih organizacija vpleta v svoje ravnanje (zaznava vpletenosti);

- ima ravnanje organizacije za posledico problem (prepoznava problema ${ }^{28}$ );

- ljudi nič ne ovira, da ne bi v zvezi z rešitvijo poskusili ukrepati (zavedanje ne oviranja).

Glede na zgornje kriterije lahko prepoznamo več stopenj razvoja javnosti:

- Kadar organizacija naredi nekaj, kar ima posledice za ljudi, oziroma kadar ljudje storijo nekaj, kar ima posledice za organizacijo obstaja verjetnost, da bodo eni ali drugi to opazili. Posledice ustvarjajo latentno javnost; to je javnost, ki je pasivna, vendar utegne postati dejavna.

- Ko se raven vpletenosti in prepoznava problema povečata in ko pride tudi do zavesti, da jih nič ne ovira pri ukrepanju, tegnejo javnosti postati zavedne in dejavne.

Hunt in Grunig sta poleg stopnje aktivnosti javnosti ugotovila, da javnosti glede na vsebino njihovega zanimanja lahko razdelimo v štiri skupine:

- vse problemske javnosti, ki delujejo na vseh problemih;

- ravnodušne javnosti, ki se ne ukvarjajo z nobenim problemom;

- eno problemske javnosti, ki se ukvarjajo le z enim problemom;

- vroče problemske javnosti, katere zanimajo le problemi, ki so trenutno zanimivi in jih mediji trenutno obravnavajo.

Znotraj organizacije prav tako lahko nastanejo javnosti. Organizacija ima poleg zunanjih tako tudi notranje javnosti. Notranje javnosti predstavljajo zaposleni in njihovi družinski člani. Mehanizem nastajanja notranjih javnosti je podoben, kot pri nastajanju zunanjih javnosti. Organizacija lahko tudi svojim zaposlenim povzroči kak problem. Vzroki za nastanek notranjih javnosti so številni. Harrisonova (1995) navaja naslednje:

- Ljudje morajo delati zelo trdo.

- Ljudje so nasploh zelo kritični.

- Še posebej mlajši nameščenci so včasih zelo kritični do managementa.

- Pogosto so nameščenci enega oddelka kritični do sodelavcev drugih oddelkov (tako imenovani prepad "mi-oni").

- Podjetja zelo veliko pozornost namenjajo skrbi za kakovost produktov, to pa predstavlja vedno večja pričakovanja od zaposlenih.

\footnotetext{
${ }^{28} \mathrm{~V}$ tem kontekstu si pod pojmom "problem" predstavljamo dejansko stanje nečesa, ki se razlikuje od želenega.
} 
- Zaposleni imajo družine in prijatelje, vsi ti pa lahko postanejo zelo kritični do organizacije.

Tudi v primeru notranjih javnosti moramo govoriti o javnostih v množini, saj imajo zaposleni različne probleme, organizacija pa jih lahko na različne načine vpleta v svoje ravnanje.

Tako notranje kot zunanje javnosti se same ustvarjajo. Organizacija mora skrbeti za ustrezno ravnanje, še preden iz posameznikov nastane javnost in še preden utegne imeti organizacija s posamezniki ali $\mathrm{z}$ javnostjo problem. Iz tega lahko izpeljemo namen komuniciranja z javnostmi. Neposredni namen komuniciranja z javnostmi je zagotoviti ugodne pogoje za delovanje organizacije.

Za razumevanje teorije javnosti in odnosov z javnostmi je potrebno, da poleg pojma javnost opredelimo tudi pojem deležniki. Deležniki so ljudje, ki so v kakršnihkoli odnosih z organizacijo in za katere je delovanje organizacije pomembno (Gruban, Verčič, \& Zavrl, 1997). 


\section{ODNOSI Z JAVNOSTMI}

Odnosi $\mathbf{z}$ javnostmi so proces dvosmernega komuniciranja in medsebojnega usklajevanja.

Splošno veljavna definicija odnosov z javnostmi pravi, da so odnosi z javnostmi proces strateškega komuniciranja, ki gradi obojestransko koristen odnos med organizacijami in njihovimi javnostmi.

Tench in soavtorji (2015) pravijo, da odnosi z javnostmi iščejo družbeno podporo in legitimnost organizacije, hkrati pa pomagajo prenesti družbene vrednote $\mathrm{v}$ identiteto organizacije.

V množici definicij pojma »odnosi z javnostmi, bistvo pove ta, ki pravi, da so odnosi z javnostmi sklepanje prijateljstev in vplivanje na ljudi. Prijatelji se med seboj uskladijo in imajo trajno dobre in iskrene odnose. Ko pa med njimi pride do nesoglasij, eden drugega na podlagi argumentov, dejstev in dokazov prepričajo.

Komuniciranje organizacije z javnostmi so lahko naključne ali pa načrtovane in planirane.

Naključni pojavi se zgodijo brez človekovega zavestnega vpliva. Časovnega razmika med dvema naključnima pojavoma ni mogoče predvideti.

Načrtovane komunikacije pa so tiste, pri katerih skrbno razmislimo o vsebini sporočila, o simbolih in o kanalih. Planirati pa pomeni opredeliti čas, dinamiko, udeležence in potrebne vire.

Pri odnosih z javnostmi gre za načrtovano in planirano komuniciranje organizacije $\mathrm{z}$ javnostmi. Odnosi z javnostmi so formalna pot, po kateri organizacije komunicirajo z javnostmi (Hunt in Grunig, 1994).

Po starem pojmovanju naj bi bil temeljni cilj odnosov z javnostmi skrb za dober image organizacije. Kot smo v tej knjigi že podrobno pojasnili, identiteta organizacije pomeni tisto, kar organizacija v resnici dejansko je. Image je za razliko od identitete miselna imitacija dejanske pojavnosti oziroma dejanske identitete organizacije. Staro pojmovanje torej pomeni, da naj bi odnosi z javnostmi ustvarjali pozitivno podobo, organizacija pa se pri tem ne bi spreminjala.

Definicija iz leta 1966 celo pravi, da je namen odnosov z javnostmi »konstrukcija družbene realnosti« (Berger, 1966).

Vendar je tako pojmovanje namena in ciljev odnosov z javnostmi že zdavnaj preživeto. $\mathrm{V}$ današnjem času, ki ga zaznamuje internet, družbena omrežja, velika razpršenost in 
svoboda medijev, odnosi z javnostmi tako postavljenega cilja sploh ne morejo doseči. Zato cilji odnosov z javnostmi presežejo okvir skrbi za dober image organizacije v okolju. Postanejo dvosmerni proces, v katerem organizacija seveda skrbi za svoj dober image, vendar mora biti sprejemljiva tudi za povratni tok komuniciranja in na podlagi tega spreminjati svojo identiteto.

Cilje odnosov z javnostmi tako lahko razvrstimo v pet stopenj (Hunt, Grunig, 1994):

Komunikacija: organizacija in javnost si izmenjujeta sporočila. Organizacija medijem »servira izjave in javnosti jih prebirajo. Organizacija pripravlja dogodke in javnosti se jih udeležujejo.

Ohranitev sporočenega: gre za to, da javnost in uprava organizacije ohranita tisto, kar jima sporoča druga stran.

Razumevanje oziroma sprejemanje kognicij; javnost in uprava organizacije sta glede nekega problema enakih misli ali prepričanj.

Sporazumevanje, ki v končni fazi prinese tudi sporazumetje. Javnost in uprava enako vrednotita problem, do njega imata enako stališče in do njega se nameravata enako vesti. Ena stran je prepričala drugo, ali pa sta se vzajemno prepričali.

Uskladitev pomeni izboljšanje razmer med organizacijo in javnostmi. Identiteta organizacije in pričakovanja okolja se uskladijo.

Strogo teoretično gledano se odnosi z javnostmi primarno nanašajo na komuniciranje organizacije z njenimi javnostmi, ne pa na komuniciranje s ciljnimi skupinami.

Tipična pojavna oblika marketinškega komuniciranja je oglaševanje. Oglaševanje je povsem drugo področje. Gre za plačano obliko brezosebne promocije, objavljeno v medijih. Oglaševanje se torej zagotovi z nakupom oglasnega prostora. Objava o organizaciji $\mathrm{v}$ medijih pa se lahko doseže tudi s tehnikami odnosov $\mathrm{z}$ javnostmi: npr. $\mathrm{s}$ pošiljanjem sporočila za javnost, $\mathrm{s}$ sklicem tiskovne konference, $\mathrm{z}$ organizacijo dogodka, ipd.

Tako odnosi $\mathrm{z}$ javnostmi kot marketinško komuniciranje so del integralnega komuniciranja organizacije.

Teoretično gledano k čistim oblikam odnosov z javnostmi nedvomno lahko prištevamo:

- komuniciranje organizacije z vladnimi službami;

- komuniciranje organizacije z mediji;

- komuniciranje organizacije z vlagatelji;

- komuniciranje organizacije z notranjimi javnostmi;

- komuniciranje organizacije z zunanjimi javnostmi. 
Gunning-ova (2012) pravi, da odnosi z javnostmi niso propaganda. Propaganda je namerno prizadevanje za pridobitev podpore za ideologijo, religijo ali prepričanje. Odnosi z javnostmi pa se skladno s konceptom usklajevanja image-a in identitete organizacije morajo osredotočati na resnico. 
Odnosi z javnostmi 


\section{ZGODOVINA ODNOSOV Z JAVNOSTMI}

Odnosi z javnostmi obstajajo približno toliko časa, kot oglaševanje. Zanimivo je, da se prve oblike odnosov z javnostmi niso pojavile v ZDA, pač pa v Evropi. V Angliji je državna zakladnica že leta 1809 imela zaposlenega "glasnika" (osebo za odnose z javnostmi).

Za enega od začetnikov prvih oblik "odnosov z javnostmi" nasploh velja pisatelj Charles Dickens, ki je leta 1842 v Angliji objavljal članke in knjigo proti delu žensk na plantažah. Iz ZDA je poznan časopis družbe Singer (iz leta 1855), ki je bil namenjen poučevanju kupcev njihovih šivalnih strojev.

Prva organizirana kampanja odnosov z javnostmi je bila izpeljana leta 1912 v Angliji, ko je vlada skušala izpeljati reformo zdravstvenega in socialnega varstva državljanov.

Med I. svetovno vojno so v ZDA potekale kampanje v zvezi z opravičevanjem udeležbe države v vojni. Tako je bilo po letu 1915 zelo intenzivno oglaševanje v zvezi s tem, prav tako tudi kampanje v medijih. po letu 1920 so se začele kampanje v zvezi s človekovimi pravicami. Leta 1920 je časopis The New York Times objavil več člankov o pravicah črncev. V tistem času so potekale tudi kampanje v zvezi z pravicami žensk in o kajenju na javnih mestih.

Za začetnika modernih "odnosov z javnostmi" v ZDA veljata Edward L. Bernays in Arthur W. Page. Bernays je svojo kariero začel leta 1915 na Broadwayu, kasneje pa je delal za različne družbe, leta 1920 pa za kubansko vlado.

Page pa je poznan po tem, da je bil od leta 1927 do leta 1946 podpredsednik uprave družbe AT\&T (ki je gigant na področju telekomunikacij). Prav on velja za enega od utemeljiteljev odnosov z javnostmi v gospodarskih družbah. Kasneje je sodeloval tudi pri predvolilni kampanji kasnejšega predsednika Eisenhowerja, pri izvajanju "Marshalovega plana" za obnovitev v II. svetovni vojni porušene Zahodne Evrope in pri delu radia "Svobodna Evropa", ki je bil namenjen propagandni dejavnosti za poslušalce v takratnih komunističnih državah.

Podobno kot za marketing, tudi za odnose z javnostmi velja, da so se sčasoma razvili v pravo znanost. Gunning-ova (2012) navaja nekatere ključne dogodke v razvoju odnosov z javnostmi:

Leta 1891 je bil rojen Edward Bernays (prvi profesor odnosov z javnostmi).

Leta 1923 se je začel prvi študijski program odnosov z javnostmi na New York University. Leta 1955 je bila ustanovljena IPRA (International Public Relations Association).

Leta 1964 je IPRA dobila formalno priznanje Združenih narodov.

Leta 1965 je bil sprejet Atenski etični kodeks (Code of Athens). 
Odnosi z javnostmi: Zgodovina odnosov z javnostmi

Leta 1978 je bil sprejet Lizbonski etični kodeks (Code of Lisbon). 


\section{MODELI IN STRATEGIJE ODNOSOV Z JAVNOSTMI}

Komuniciranje organizacije $\mathrm{z}$ javnostmi je mogoče opraviti na več načinov. Gre za različne dimenzije:

- enosmerno ali dvosmerno komuniciranje;

- uporabo različnih kanalov komuniciranja;

- časovno dinamiko komuniciranja;

- pristope k oblikovanju vsebine sporočil;

- organizacijske pristope k izvajanju;

- odnosni vidik med oddajnikom in sprejemnikom sporočil;

- odnosni vidik med oddajnikom in medijem, ter med sprejemnikom in medijem, ki služi za prenos sporočil;

- druge dimenzije.

Vse te dimenzije so se skozi zgodovino spreminjale in se še vedno razvijajo. Teorija jih opisuje z izrazi: »modeli «, »strategije «, »okviri« idr.

V drugi polovici 20. stoletja so se zelo uveljavili »modeli odnosov z javnostmi«, po katerih organizacije tudi danes še vedno prakticirajo izvajanje odnosov z javnostmi. Modele sta razvila James Grunig in Todd Hunt. Verčič (1998) pravi, da je Grunig začel razvijati teorijo odnosov $\mathrm{z}$ javnostmi že $\mathrm{v}$ šestdesetih letih prejšnjega stoletja. Teoretični modeli odnosov z javnostmi so bili predstavljeni leta 1984. Značilni modeli so ${ }^{29}$ :

- model agenture ali tiskovnega predstavništva;

- model obveščanja javnosti;

- dvosmerni asimetrični model;

- dvosmerni simetrični model.

K modelu agenture ali tiskovnega predstavništva sodijo programi odnosov z javnostmi, katerih edini namen je, da organizaciji pridobijo ugodno publiciteto v množičnih občilih. Naloga agenta je, da organizira dogodke, kot so tiskovne konference in da medijem posreduje sporočila za objavo. Agentura je običajna za oblikovanje image-a športnikov, filmskih zvezd, politikov ipd. To je enosmerni model, saj agent zgolj pošilja sporočila.

Javno informacijski model ali model obveščanja javnosti je prav tako enosmerni model. V odnosih z javnostmi ne vidi drugega kot razširjanje sporočil. V ta namen uporablja "hišne novinarje" - izvajalce odnosov z javnostmi. Ti delujejo, kot da so neodvisni novinarji. Bolj ali manj objektivna sporočila širijo $\mathrm{v}$ javnih medijih in $\mathrm{v}$ nadzorovanih medijih. Tudi množični mediji se navzven deklarirajo kot neodvisni mediji.

${ }^{29}$ Povzeto po Hunt, Grunig, 1994 in Harrison, 1995 
Poznani so primeri, ko so za odnose organizacij z javnostmi skrbele agencije, ki so bile lastniško povezane $\mathrm{z}$ medijskimi hišami.

$\mathrm{Z}$ vidika komuniciranja organizacije $\mathrm{v}$ luči preučevanja možnosti uporabe javno informacijskega modela, je medije pomembno proučevati iz vidika odnosa med lastništvom, nadzorom in vsebino. Kot vemo, so sodobni mediji običajno organizirani kot gospodarske družbe. Lastniki medijev za vsebinsko in za tehnično realizacijo vsebin sporočanja najamejo osebje. Novinar naj bi bil po Wattsu (1997) uslužbenec birokratske organizacije, katera posluje po tržnih načelih. Med razpoložljivimi novicami ob spoštovanju načel profesionalne etike odloča, katere novice in iz katerih virov bo posredoval javnosti.

Novica je informacija, ki je posredovana od vira prek medija do javnosti ob posredovanju novinarja (Watts, 1997).

Glede na odnos med lastniki, nadzorom nad mediji in vsebino sporočanja Watts (1997) loči tri osnovne tipe medijev:

- pluralistični tip medija;

- manipulativni tip medija;

- hegemonistični tip medija

Pluralistični tip je značilen za demokratične družbe s tržno ekonomijo. Lastniki in uredniki vplivajo na vsebino po načelih profesionalne etike. Dopustna je vsebinska prilagojenost zahtevam ciljne skupine publike, kateri je medij namenjen. Obstaja celo načelo, da je publika tista, ki po vsebinskem vidiku oblikuje medij. Poročanje o stanjih in dogodkih mora biti realno, objektivno in nepristransko. Viri informacij so raznoteri, od različnih tiskovnih agencij, dopisnikov. V medije pluralističnega tipa ima dostop tudi javnosti. To velja tudi za poročanje o dogodkih iz politike. Enaka načela veljajo tudi za medije, ki imajo naravo tako imenovanih "tabloidov". Način sporočanja $\mathrm{v}$ tabloidih (pluralističnega tipa) naj bi namreč služil pridobivanju ekonomskih učinkov, ne pa diskreditaciji posameznikov.

Mediji, ki izhajajo iz manipulativnega modela, imajo pogosto zelo homogeno publiko. Izhajajo iz ideoloških predispozicij, ki so lahko spretno prikrite, kar pa spet ni nujno. Vsebina sporočanja medijev manipulativnega tipa je prilagojena specifičnim potrebam. Praviloma imajo vedno ene in iste vire informacij. Svojo publiko informirajo enostransko in tendenciozno..

Oba opisana modela sta ekstremna. Vmesni model je hegemonistični tip medija. Tipično za te medije je, da je vsebina njihovega sporočanja zelo heterogena (v nasprotju z vsebino medijev manipulativnega modela), vendar pa hegemonistični tip medija o zadevah zavzema določena stališča. Gre za stališča o političnih, socialnih in ekonomskih vprašanjih. Pri tem tipu medijev je pogosto tudi tako imenovano "generiranje novic«. Gre zato, da nek medij o majhnem, na videz nepomembnem dogodku poroča, kot da bi bil velik, zelo pomemben dogodek in ga poskuša prikazati na način, ki doseže nek namen. 
Hegemonistični tip medija je navadno namenjen informiranju tako imenovanega srednjega sloja.

Dvosmerni asimetrični model je, kot že ime pove dvosmerni model. Na podlagi raziskav stališč javnosti razvija sporočila, ki utegnejo prepričati strateško pomembne javnosti, naj se obnašajo, kakor bi rada organizacija. Kot že ime modela pove, gre pri uporabi tega modela za dva procesa:

- raziskovanje javnega mnenja;

- posredovanje sporočil javnostii.

Običajno raziskave javnega mnenja opravljajo za to usposobljene agencije. Sporočilo javnosti se razvije šele na podlagi poznavanja javnega mnenja z namenom učinkovati na javnost. Ta model je učinkovitejši kot prva dva opisana modela. Prednosti pokaže zlasti $\mathrm{v}$ primeru komuniciranja $\mathrm{z}$ javnostjo $\mathrm{v}$ času konfliktov.

Četrti model je dvosmerni simetrični model. Obsega tiste odnose z javnostmi, ki temeljijo na raziskavah. Pri tej obliki komuniciranja med organizacijo in javnostmi naj bi bili učinki bolj uravnoteženi. Organizacija raziskuje mnenje javnosti. Pride do medsebojnega vplivanja. Gre torej tudi za vplivanje na organizacijo, ne zgolj na javnost. Ta model komuniciranja se uporablja zato, da bi obvladali konflikt in se bolje razumeli s strateškimi javnostmi.

Teoretični modeli odnosov z javnostmi, katere sta razvila Grunig in Hunt ves čas doživljajo številne kritike ${ }^{30}$ :

- da so že sami po sebi preveč statični;

- da odnose z javnostmi prestrogo ločujejo od marketinškega komuniciranja;

- da pojem »javnost« v dobi interneta, ko se javnosti neprestano same ustvarjajo, opredeljujejo preveč statično;

- $\quad$ predvsem pa, da so nastali v dobi, ko še ni bilo interneta.

Glavna kritika modelov odnosov z javnostmi je ta, da je samo eden od modelov dvosmerni simetrični model. Zgolj dvosmerno simetrično komuniciranje je tisto, ki omogoča tudi spreminjanje organizacije.

Vendar pa je modele treba ocenjevati tudi iz vidika časa, v katerem so nastali.

Kljub vsem kritikam pa ostaja občutek, da so modeli tako v teoriji kot v praksi v zadnjih 30 letih še vedno dominantni. S pojavom novih medijev in z razvojem družbe pa se seveda pojavljajo novi pristopi in nove paradigme.

Hallahan (1999) je tako predlagal »Tipologijo sedmih modelov okvirjanja odnosov $z$ javnostmi $\ll$, ki predstavljajo drugačno paradigmo od modelov odnosov z javnostmi.

${ }^{30}$ Glej npr.: Kenny, J. (2016): Excellence Theory and its Critics: A literature rewiew critiquing Grunig's strategic mangement of public relations paradigm, Asia Pacific Public Relations Journal, Vol. 17, No. 2, pag 78-91. 
Tipologija sedmih modelov okvirjanja odnosov z javnostmi ima naslednje okvire:

1. Situacija: gre za vprašanja, kakšne so $\mathrm{v}$ dani situaciji relacije med posamezniki.

2. Lastnosti: gre za dejanske lastnosti ljudi, stanj in stvari glede ključnih atributov.

3. Izbira: gre za to, da vsaka izbira vključuje negotovost. Ključni razmislek glede ravnanja pa je, ali bomo delovali tako, da bodo odnosi šli v pozitivno ali v negativno smer.

4. Akcija: gre za to, da je isti cilj mogoče doseči z različnimi akcijami.

5. Vprašanja: gre za to, da je probleme in spore s strani različnih ljudi možno razložiti na različne načine.

6. Odgovornost: gre za način, kako posameznikom pripisovati vlogo in odgovornost v dogodkih.

7. Novice: gre za to, da mediji običajno poročajo o znanih temah.

Grunig in ostali (2002) so kasneje predlagali odmik od modelov k dimenzijam strategij odnosov z javnostmi. Študenti Gruniga (Huang, 2004; Rhee, 2002; Sha, 2006; Sha, 2009) so predlagali sedem novih dimenzij: enosmerno, dvosmerno, asimetrično, simetrično, medosebno, posredno in etično komuniciranje. Imenovali so jih strategije odnosov zjavnostmi.

Bistvena lastnost novih predlogov je:

- da odnosi z javnosti postajajo vedno bolj dvosmerni in simetrični ter

- da kot taki dejansko omogočajo tudi spreminjanje organizacije.

Medosebno komuniciranje je lahko neposredno ali posredno. Osebno komuniciranje poteka neposredno med ljudmi (iz oči v oči). Predstavlja način, kako se razviti osebni vpliv na ključne posameznike, kot npr. iz medijev, vlade, politike in med aktivisti gibanj ipd.

Posredno komuniciranje večinoma poteka prek množičnih medijev (televizija, radio, tisk, spletno komuniciranje).

Asimetrično komuniciranje je neuravnoteženo, saj pušča organizacijo takšno, kot je. Organiazcija s pošiljanjem sporočil poskuša spremeniti javnosti.

Pri simetričnem komuniciranju gre hkrati za spreminjanje javnosti in organizacije. Zahteva obojestransko razumevanje in obvladovanje nasprotij. Cilj je uravnoteženo simetrično komuniciranje s ciljem ustvarjanja vzajemno koristnega odnosa.

Kulturno prevajalstvo je način, katerega se poslužujejo mednarodne organizacije, katerih podružnice so v lokalnih okoljih. Mednarodne organizacije potrebujejo nekoga, ki razume lokalne posebnosti: jezik, kulturo, navade in politični sistem. Zato najemajo lokalne strokovnjake za odnose z javnostmi. 
Navedeni načini izvajanja odnosov z javnostmi ne predstavljajo končne stopnje razvoja odnosov z javnostmi. Phillips in Young (2009) pravita, da je konec 20. stoletja prišlo do "90 stopinjskega obrata « v vektorju komunikacije. Pozno 20. stoletje je namreč prineslo pomembne spremembe v načinu, kako ljudje prejmejo informacije. Od leta 2000 dalje, je pojav novih spletnih platform in socialnih omrežij, prinesel korenite spremembe v načinu, kako ljudje izmenjujejo informacije. Množični mediji, zlasti časopisi, so zašli v velike težave. Temu primerno se bodo morali prilagoditi tudi načini izvajanja odnosov z javnostmi. Tudi avtor klasičnih teoretičnih modelov odnosov z javnostmi James Grunig (Grunig, 2009) ugotavlja, da je bilo npr.: junija 2009 kar 1,668,870,408 uporabnikov interneta. Temu se prilagajajo tudi odnosi z javnostmi. Forumom, blogom in portalom se ni več mogoče izogniti. To prinaša tudi konceptualne spremembe. Na koncu svoje knjige tudi James Grunig pravi, da bodo odnosi z javnostmi z razvojem novih medijev pač morali postati še bolj simetrični. 
Odnosi z javnostmi 


\section{MANAGEMENT ODNOSOV Z JAVNOSTMI}

Za odnose $\mathrm{z}$ javnostmi je bistveno, da so vključeni $\mathrm{v}$ management organizacije. To pomeni, da:

- morajo biti opredeljeni cilji odnosov z javnostmi;

- morajo biti opredeljene konkretne naloge;

- naloge in dejavnosti odnosov z javnostmi morajo biti skrbno planirane;

- mora biti vzpostavljena ustrezna organizacijska struktura, (vključujoč službo za odnose z javnostmi), ki omogoča doseči cilje odnosov z javnostmi;

- je treba izvajati kontrolno funkcijo;

- je treba rezultate dejavnosti vrednotiti in dejavnosti (to je vsebine, metode in dinamiko izvajanja) po potrebi prilagajati konkretnim okoliščinam.

Verčič (1998) navaja tri glavne nivoje strateškega managementa odnosov z javnostmi:

Nivo deležnikov: Organizacija ima odnos z deležniki, ko ima vodenje organizacije ali deležnika posledice za drugega. Odnosi z javnostmi morajo skrbno raziskati okolje in vedenje organizacije, da ugotovijo posledice delovanja organizacije za druge subjekte.

Stalno komuniciranje z deležniki pomaga ustvariti stabilen dolgoročen odnos, ki ureja morebitne spore.

Nivo javnosti: Javnosti se pojavijo, ko deležniki eno ali več posledic delovanja organizacije prepoznajo kot problem. Zato se organizirajo, da bi nekaj storili. Odnosi z javnostmi morajo z raziskavo prepoznati problem in segmentirati te javnosti.

Nivo problema: Javnosti se organizirajo in ustvarjajo zaradi problemov. Odnosi z javnostmi morajo (potencialne in dejanske) probleme vnaprej predvideti ter jih upravljati in voditi odziv organizacije nanje.

Najbolj tipične oblike komuniciranja organizacije z javnostmi slej ko prej ostajajo: dogodek, kampanja in program.

Dogodek je enkraten. »Zgodi« se v enotnem časovnem okviru. Dogodke navadno skrbno planiramo in organiziramo. S planiranjem in organiziranjem dogodkov želimo doseči cilj v zvezi z eno ali več javnostmi. Cilji, katere želimo doseči z dogodkom, so: navzočnost določenih (določenega števila) ljudi, enkratno posredovanje informacij, javno izražanje stališča in pridobivanje medijske pozornosti ter pozornosti javnosti in ciljnih skupin.

Dogodki so namenjeni oblikovanju identitete organizacije, vplivanju na ugled, in krepitvi zadovoljstva strank. 
Iz definicije izhaja, da so dogodki organizacije usmerjeni na:

- notranjo javnost organizacije v smislu graditve identitete;

- zunanje javnosti v smislu graditve ugleda;

- poslovne in druge partnerje $\mathrm{v}$ smislu ohranjanja trajnega odnosa.

- sedanje in potencialne kupce $\mathrm{v}$ smislu ohranjanja trajnega odnosa, graditve ugleda in zagotavljanja zadovoljstva.

Pozornost dosežemo z:

- vabljenjem na dogodek;

- izvedbo dogodka;

- pošiljanjem sporočil za medije;

- pošiljanjem zahval za udeležbo;

- objavami na družbenih omrežjih.

Priložnosti za organizacijo dogodkov so:

- zaključek poslovnega leta;

- predstavitev novih produktov;

- uspehi in prejem zunanjih priznanj;

- uspehi tistih, ki jih organizacija sponzorira;

- razni jubileji in obletnice;

- forumi in konference;

- obiski uglednih posameznikov;

- otvoritve;

- drugo.

Na dogodkih se daje pomen:

- predstavitvi kontinuitete organizacije;

- poudarjanju razlikovanja organizacije od drugih;

- poudarjanju zanesljivosti, kredibilnosti, družbene odgovornosti;

- predstavitvi ambasadorjev organizacije;

- atributom, s katerimi organizacija vzdržuje konkurenčnost.

Dogodki so lahko povezani z marketinškimi aktivnostmi:

- predstavitev posebnih modelov produktov;

- posebni pogoji financiranja;

- podaljšana garancija;

- posebne poprodajne ugodnosti;

- drugo. 
Kampanja je proces, ki sestoji iz več različnih dogodkov, ki po vsebini niso nujno med seboj povezani. Tudi kampanje skrbno planiramo in organiziramo. Bistveno pri razumevanju kampanje je, da je na koncu kampanje vedno odločanje o nečem (npr. volitve, glasovanje ipd.). Cilj kampanje je doseči ravnanje na želen način (npr. ugoden volilni izid).

Program je podoben kampanji. Sestoji iz množice dogodkov, ki niso nujno med seboj povezani. Od kampanje se razlikuje po tem, da nima določene točke izteka. Program se izvaja, dokler obstaja potreba, oziroma, dokler ne porabimo predvidenih sredstev. Cilj programa je razumevanje (npr.: ustvarjanje in ohranjanje podpore organizaciji, ki izvaja neko dejavnost). 
Odnosi z javnostmi 


\section{ODNOSI Z VLAGATELJI}

Odnosi z vlagatelji so posebej pomembni za finančne trge. Kot pravita Ryan in Jacobs (2005) finančni trgi »tekmujejo« za kapital in poudarja, da je ekonomija vedno »lačna« kapitala. Odnosi $\mathrm{z}$ vlagatelji se torej nanašajo na udeležence na trgu finančnih instrumentov.

$\mathrm{Z}$ vidika ekonomskih kategorij vlagatelje zanima:

- ohranitev vrednosti naložbe;

- varnost naložbe;

- dobičkonosnost naložbe;

- način razporejanja dobička;

- možnost špekuliranja.

Namere obstoječih ali potencialnih vlagateljev so lahko:

- prodati;

- obdržati;

- kupiti oziroma dokupiti;

- neodločenost, kaj storiti.

Na ceno delnic in drugih finančnih instrumentov na trgu vplivajo številni dejavniki:

- stanje aktive in pasive v bilanci stanja izdajatelja;

- boniteta izdajtelja;

- pričakovana vrednost bodočih poslovnih izidov izdajatelja;

- pričakovana vrednost bodočih donosov;

- trenutna ponudba in povpraševanje;

- aktualne informacije o poslovnih in drugih dogodkih;

- pojav krize, ki ima naravo »napada na ugled« organizacije.

Stephen Goldfeld in Richard Quandt sta že leta 1965 s statistično analizo ugotovila, da na borzi vsaka javno objavljena informacija vpliva na ceno delnic.

Vlagatelji javno objavljene informacije zaznajo in pride do percepcije. Na osnovi zaznav se pojavijo tudi čustva. Čustva ob zaznavi javno objavljenih informacij so odvisna od situacijskih dejavnikov in so lahko zelo različna. Iz zgodovine trgovanja s finančnimi instrumenti je poznaih več primerov, ko so zaznave povzročile odziv celotnega človeškega telesa (npr. srčni napadi, ipd.) 
Tipična čustva na trgu finančnih instrumentov so:

- strah za varnost naložbe, kadar so sporočila za vlagatelje neugodna;

- panika;

- evforija,

Percepcija in čustva vplivajo na odločitve o nakupu oziroma prodaji. Trenutna ponudba in povpraševanje pa vplivata na ceno.

Navedli smo že primer, ki ga opisuje Mitkova (2014). Pravi, da so bili ljudje bolj pripravljeni igrati igre s kartami za denar v primeru, ko so na hrbtni strani kart fotografije ljubkih otrok, kot v primeru, ko so karte nevtralnih barv. Navedla je tudi primer oglaševanja tveganih investicijskih skladov, kjer so $\mathrm{v}$ ozadju slike mesta. Torej ni nobenega dvoma, da odnosi z vlagatelji lahko vplivajo tako na ceno, kot na odločitve ljudi o nakupu oziroma prodaji vrednostnih papirjev.

Odnosi z vlagatelji so se oblikovali kot posebna disciplina znotraj siceršnjih odnosov z javnostmi. Kot pravi Guimard (2008) je naloga odnosov z vlagatelji, da skladno z zakonodajo omogoči vsem zainteresiranim, da vsi pod enakimi pogoji dobijo potrebne informacije o delnicah, obveznicah in drugih finančnih instrumentih. Odnosi z vlagatelji so sicer disciplina, ki po vsebini najprej sodi v domeno finančno-računovodske funkcije $\mathrm{v}$ organizaciji.

$\mathrm{Z}$ razvojem trga finančnih instrumentov so vlagateljem kot eni od javnosti organizacije začele namenjati zelo velik pomen. Razvite so bile posebne metode komuniciranja $\mathrm{z}$ njimi. Za odnose $\mathrm{z}$ vlagatelji se uporabljajo, oziroma se $\mathrm{v}$ nekaterih primerih celo morajo uporabljati prav za to namenjeni kanali komuniciranja. Kanali komuniciranja so včasih celo še bolj pomembni, kot sama vsebina.

Temeljno načelo odnosov z vlagatelji je družbeno odgovorno ravnanje. Odnosi družb z vlagatelji in poročanje imajo javni pomen. Dolžnosti poročanja opredeljuje tudi zakonodaja. Zakonsko določene dolžnosti poročanja se nanašajo na:

- opredelitve zavezancev za poročanje;

- opredelitve poslovnih in drugih dogodkov, o katerih je potrebno poročati;

- opredelitve pojavnih oblik poročil;

- odgovorne osebe za poročanje;

- opredelitve prejemnikov poročil;

- načine distribucije poročil;

- zahteve glede vsebine poročil;

- roke za poročanje;

- načine nadzora nad poročanjem;

- pristojnosti organov nadzora;

- kazni za fizične in pravne osebe v primeru kršitev dolžnosti poročanja;

- drugo. 
Zakonodaja prepoveduje nekatere vsebine oglaševanja finančnih instrumentov.

Poleg dolžnosti poročanja so naloge odnosov z vlagatelji še:

- $\quad$ pridobivanje dodatnega kapitala za doseganje ustrezne stopnje rasti;

- doseganje ali branjenje želenega tečaja finančnega instrumenta na borzi;

- preprečevanje sovražnih prevzemov;

- upravljanje odnosov z javnostmi v primerih poskusa prevzema;

- vplivanje na (večjo ali manjšo) privlačnost transakcij s finančnimi instrumenti posameznega izdajatelja na trgu vrednostnih papirjev;

- preprečevanje neželenega prometa;

- preprečevanje presenečenj, ki bi lahko ogrozila stabilno upravljanje družbe;

- drugo.

Do leta 1991 so bila podjetja v Sloveniji last države oziroma so imela status »družbne lastnine«. Po letu 1991 je prišlo do privatizacije. Med procesom lastninjenja lahko prepoznamo vsaj tri faze nastajanja dolgoročne lastniške strukture družb:

- distribucijska faza (razdelitev lastniških certifikatov med državljane);

- konsolidacija lastniške strukture (zmanjševanje števila naključnih delničarjev);

- vzpostavitev stabilne lastniške strukture.

Lahko štejemo, da privatizacija v Sloveniji še ni povsem zaključena. Zaradi certifikatnega modela privatizacije pri nas in s tem specifičnosti nastanka lastništva gospodarskih družb je lastniška struktura marsikje še vedno nestabilna. Država ima še vedno v posredni ali neposredni lasti pomembne deleže nekaterih gospodarskih družb. Pomembni lastniki so tudi mali delničarji.

Ravnanje države je pogosto odvisno od trenutnih političnih interesov.

Razmišljanje in ravnanje malih delničarjev pa je pogosto neodvisno od tržnih gibanj. Povzročajo ga lahko povsem osebne okoliščine.

Uprave družb naj bi se načeloma ne ukvarjale z lastniško strukturo in s privatizacijo. Delniška družba torej ne more vedno vplivati na okoliščine, ki delujejo kot povodi za ravnanje. Zato je komuniciranje z delničarji za uprave družb pomembno. Usmerjeno je na tiste spremenljivke, na katere lahko družba lahko vpliva. V prvi vrsti je to svoj ugled. 
Odnosi z javnostmi 


\section{ODNOSI Z NOTRANJIMI JAVNOSTMI}

Pojavne oblike komuniciranja vodstva organizacije z notranjimi javnostmi so:

- individualni razgovori;

- razgovori s skupino;

- nagovor vodstva zaposlenim;

- srečanja nameščencev vse organizacije;

- hišni časopis;

- pismo nameščencem;

- E-mail;

- Intranet;

- sporočila ob plačilnih listkih;

- prezentacije;

- proslave praznikov;

- drugo.

Posamezne oblike se lahko med seboj prepletajo. Gre pa za uporabo bolj ali manj tradicionalnih kanalov komuniciranja. Izmed digitalnih kanalov komuniciranja $\mathrm{v}$ organizacijah pomembno vlogo prevzema intranet, ki je praktično izrinil »oglasno desko«. Mlajše generacije zaposlenih marsikje sploh niso imele priložnosti videti oglasne deske. Intranet je postal nekaj samoumevnega.

$\mathrm{Z}$ vidika notranjega komuniciranja vse pomembnejše postaja tudi komuniciranje prek socialnih omrežij in mikroblogov. Težko si sicer predstavljamo, da bi vodstvo organizacije z zaposlenimi komuniciralo preko odprtih družbenih omrežij. Toda ta omrežja imajo pomembno vlogo pri neformalnem zasebnem komuniciranju in druženju med zaposlenimi.

Kot smo že omenili, raziskave (npr.: Rybalko, Seltzer, 2010) kažejo, da se uporaba mikroblogov vodstva praviloma ne usmerja na zaposlene, čeprav je dokazano, da ima uporaba »twitterja« pozitivne kognitivne in vedenjske učinke na zaposlene. Raziskave (npr.: Hwang, 2012) so pokazale, da zaposleni večinoma pozitivno ocenjujejo uporabo Twitterja s strani direktorja.

Socialna omrežja ponujajo tudi možnost za neželeno komuniciranje članov organizacij. Nekateri avtorji (npr.: Rose, 2013) trdijo, da zaposleni kot posamezniki reagirajo na nadzor delodajalca in na druge prisilne prakse $\mathrm{z}$ uporabo socialnih medijev in zlasti blogov. Odzivajo se praviloma anonimno. Vsebine pa so za organizacijo neželeni komentarji. 
Komuniciranje preko socialnih omrežij po drugi strani omogoča mnogo bolj dvosmerno komuniciranje. Oddajniki sporočil o organizaciji pogosto niso več zgolj vodstva organizacije, pač pa tudi posamezniki, zaposleni $\mathrm{v}$ organizacijah. To prinaša prednosti dvosmernega komuniciranja, vendar po drugi starni žal tudi nove probleme. Nastajajo namreč novi razlogi delovno-pravnih sporov med zaposlenimi in delodajalci. Literatura (npr. McDonald, Thompson, 2016) opisuje naslednje:

- uporabo spletnih medijev za zaščito osebnih interesov;

- žaljive objave na blogih in forumih;

- žaljiva sporočila posameznikom;

- zasebno uporabo družbenih omrežij med delovnim časom.

Številni raziskovalci (npr.: Gray in Laidlaw, 2004). so prepoznali dve dimenziji komuniciranja med člani organizacij:

- Informacijska dimenzija je osredotočena na sistem komuniciranja, predvsem na vsebino in kanal, (kot ključna elementa sistema komuniciranja).

- Odnosna dimenzija je osredotočena na zadovoljstvo članov organizacije z odnosom, ki pri komuniciranju nastane.

$\mathrm{Z}$ odnosno dimenzijo komuniciranja $\mathrm{v}$ organizacijah so se ukvarjali številni raziskovalci. Pot do spoznanj, kaj odnosna dimenzija komuniciranja v organizacijah sploh je, kaj za organizacijo pomeni in kako jo merimo, je bila precej dolga.

Za »očeta« preučevanj komuniciranja znotraj organizacije velja Charles Redding. Redding je postavil postulate komuniciranja znotraj organizacij. Njegove postulate lahko povzamemo v sledečem:

- Vsi simboli v organizaciji (tako verbalni kot neverbalni) so lahko potencialno sporočilo.

- Ravnanje osebja lahko povzroči zgolj tisto sporočilo, ki ga oddajnik pošlje in ki ga prejemnik tudi sprejme.

- Vsako komuniciranje v organizaciji zahteva vložek energije.

- Če je med člani organizacije preveč sporočil, jih morda člani organizacije sploh ne bodo zaznali. Tudi če jih bodo zaznali, jih morda ne bodo percepirali, kot si je želel pošiljatelj.

- Če prejemnik sporočila ni percepiral tako, kot je pričakoval pošiljatelj, se bo prejemnik skliceval na napačno vsebino.

- Kadar se sporočilo prenaša preko več različnih oseb, se pomen sporočila lahko spremeni.

Renato Tagiuri je leta 1968 med prvimi definiral pojem organizacijska klima (organization climate). Po njegovem je organizacijska klima kakovost notranjega okolja organizacije, ki:

- jo člani organizacij zaznavajo; 
- vpliva na obnašanje (ravnanje) članov organizacije;

- vpliva na sistem vrednot članov organizacije (Jablin, 1987, po Tagiuri, 1968).

Redding (1999) je trdil, da ima organizacijska klima pet dimenzij, ki so:

- medsebojna podpora;

- participacija pri odločanju;

- medsebojno zaupanje in verodostojnost;

- odprtost in iskrenost;

- skupni cilji.

Frederic Jablin (1987) pa je opredelil komunikacijsko klimo kot zaznana pričakovanja in gledanja članov organizacije na proces komuniciranja, ki poteka $\mathrm{v}$ okviru procesov znotraj organizacije.

Zadovoljstvo s komuniciranjem (communication satisfaction) je evalvacija komunikacijske klime. Temelji na subjektivnih doživljanjih članov organizacije (Tukiainen, 2001). Hecht je opredelil zadovoljstvo s komuniciranjem kot »socioemocionalni rezultat « interakcij, ki izhaja iz interpersonalnega komuniciranja med člani organizacije (Gray\&Laidlaw, 2004, po Hecht, 1978).

Sistem komuniciranja $\mathrm{v}$ organizaciji sestoji iz oddajnikov, sprejemnikov, vsebin in kanalov. V organizaciji mora funkcionirati tako, da za to pristojne osebe pošiljajo sporočila po običajnih kanalih. Sprejemniki jih zaznajo in percepirajo.

Zadovoljstvo s komuniciranjem je mnenjski odziv posameznika na delovanje sistema komuniciranja.

Vendar na mnenjski odziv ne vpliva samo sitem komuniciranja. Pogosto se dogaja, da nadrejeni članom organizacije po običajnih kanalih pravočasno pošiljajo vsebinsko popolna sporočila. Zaposlenim zagotovijo participacijo pri odločanju, delujejo verodostjno, odprto in iskreno,. Rezultati raznih anketiranj o zadovoljstvu s komuniciranjem med člani organizacije pa neredko pokažejo slabe rezultate.

Vsak manager mora vzpostaviti delujoč sistem notranjega komuniciranja v organizaciji. Ob tem pa se mora zavedati, da je zadovoljstvo zaposlenih zgolj »subjektivno doživljanje dejanskega stanja«. Če imamo v avtu poleti nastavljeno temperaturo 22 stopinj, bo v poletni vročini za nekoga prehladno. Pozimi pa bo pri isti temperaturi v avtu nekomu vroče. Podobno je z zadovoljstvom s komuniciranjem znotraj organizacije. Doživljanje lahko sploh ne odrazi dejanskega stanja v organizaciji. Ni odvisno samo od managementa, pač pa tudi od dejavnikov okolja in od vsakega posameznika.

Komunikacijsko udobje je prav tako že pred desetletji definiral Pavao Brajša. Brajša (1994) pravi, da so člani organizacije zmožni komunicirati samo, če so čustveno zadovoljeni (torej, da niso prikrajšani oziroma frustrirani). 
Komunikacijsko udobje ima po Brajši pet dimenzij:

- vsebinsko;

- prostorsko;

- časovno;

- delovno;

- čustveno.

Vsebinsko komunikacijsko udobje je pravica do podobnosti in različnosti mnenj, idej in predlogov. To je pravica misliti drugače.

Prostorsko komunikacijsko udobje pomeni pravico do bližine in oddaljenosti vseh sogovornikov. To pomeni, da ima vsakdo pravico do bližine in oddaljenosti. Nihče nima pravice vstopiti v ta prostor brez dovoljenja.

Časovno komunikacijsko udobje je pravica vseh udeležencev do lastnega določanja začetka, konca in trajanja komuniciranja.

Delovno komunikacijsko udobje pomeni pravico udeležencev, da so pri komuniciranju aktivni ali pasivni.

Čustveno komunikacijsko udobje je razmerje med gratifikacijo (zadoščenjem) in frustracijo (prikrajšanostjo) v procesu komuniciranja.

V nadaljevanju predstavljamo rezultate raziskave, s katero smo v prvi vrsti želeli ugotoviti:

1. Katere vsebine so tiste, ki zaposlene $\mathrm{v}$ organizacijah $\mathrm{v}$ Sloveniji najbolj zanimajo?

2. Kakšno je zadovoljstvo s komuniciranjem glede na posamezne vsebine komuniciranja v organizacijah?

Za zbiranje podatkov smo uporabili tehniko anketiranja. Anketarji so osebno anketirali 1000 oseb, izključno zaposlene na območju Slovenije. 31 vprašalnikov smo zaradi različnih napak izločili, tako da smo za analizo uporabili 969 pravilno izpolnjenih vprašalnikov. V vzorcu je bilo $443(45,6 \%)$ moških in $526(54,4 \%)$ žensk. Starostna in izobrazbena struktura vzorca je bila reprezentativna.

Pri oblikovanju anketnih vprašanj glede zadovoljstva s komuniciranjem smo izhajali iz opredelitev vsebin komuniciranja managerja z osebjem, kakor ga je definiral Robertson. Robertson (2005) vsebine komuniciranja vodij deli na:

(1) vsebine komuniciranja s podrejenimi v zvezi z delom;

(2) vsebine komuniciranja s podrejenimi, ki se nanašajo izključno na posameznika;

(3) zadeve oddelka; 
(4) strateške vsebine, kot npr. lastništvo organizacije, informacije o trgih, poslovnem izidu, ipd.;

(5) komuniciranje z nadrejenimi;

(6) vsebine, katerih namen je koordiniranje.

Za ocenjevanje zadovoljstva smo uporabili pet stopenjsko lestvico.

Anketirancem smo najprej postavili vprašanja o vsebinah, katere jih v okviru podjetja, kjer so zaposleni, zanimajo. Vprašalnik je bil zaprtega tipa, ponudili smo odgovore:

VSEBINA

$$
\text { 1. nič me }
$$

2. dovolj,

3. dovolj,

4.

da samo

da delno

želim

5.želim podrobno

slišim za

poznam

to

pozna

ti

Frekvence odgovorov so prikazane v tabeli 4.

\section{Tabela 4: Vsebine, ki zanimajo zaposlene $(n=969)$}

\begin{tabular}{|l|c|c|}
\hline $\begin{array}{l}\text { V kolikšni meri vas v podjetju, kjer ste } \\
\text { zaposleni, zanimajo vsebine: }\end{array}$ & $\begin{array}{c}\text { Povprečna } \\
\text { vrednost }\end{array}$ & $\begin{array}{c}\text { Standardni } \\
\text { odklon }\end{array}$ \\
\hline o poslovnem izidu in vrednosti podjetja & 3,61 & 1,061 \\
\hline o lastništvu podjetja & 3,53 & 1,105 \\
\hline o produktih in trgih & 3,68 & 1,099 \\
\hline o (re)organiziranosti & 3,80 & 1,071 \\
\hline o spremembah v vodstvu & 3,95 & 0,993 \\
\hline o kadrovskih zadevah & 3,83 & 1,025 \\
\hline o plačah & 4,27 & 0,889 \\
\hline o možnostih (moje) kariere & 4,40 & 0,845 \\
\hline o zadevah mojega oddelka & 4,54 & 1,802 \\
\hline o varnosti zaposlitve & 4,50 & 0,763 \\
\hline o“izrednih” dogodkih & 3,95 & 0,976 \\
\hline
\end{tabular}

Zaposlene glede vsebin komuniciranja v organizaciji najbolj zanimajo zadeve, ki se navezujejo na njihov oddelek $(M=4,54$ in $S D=1,802)$, varnost zaposlitve $(M=4,50$ in $S D=0,763)$, možnosti glede njihove kariere $(M=4,40$ in $S D=0,845)$ in plače $(M=4,27$ in $S D=0,889$ ). Glede na zelo majhno standardno deviacijo bi si upali trditi, da je na prvem mestu glede na zanimanje varnost zaposlitve. Glede na izračunano povprečno vrednost je za zaposlene na videz sicer pomembnejša informiranost o zadevah njihovega oddelka, vendar izstopa zelo velika standardna deviacija, kar pomeni zelo veliko neenotnost stališčih anketirancev glede pomembnosti informacij, ki so »zadeve oddelka«.

Ljudje zaradi tega, ker nas nadrejeni ne seznanijo z vsem, oziroma nas ne seznanijo pravočasno, doživljamo občutke prikrajšanosti (frustracije). Nasprotno lahko 
doživljamo tudi občutke zadovoljenosti. Spraševali smo, s katerim odgovorom bi vprašani najbolje izrazili svoja občutenja čustev glede zadovoljenosti/prikrajšanosti o posameznih vsebinah v podjetju, kjer so zaposleni. Ponudili smo odgovore: 1-zelo zadovoljen, 2-zadovoljen, 3-ne vem, 4-prikrajšan, 5-zelo prikrajšan.

Glede zadovoljstva s komuniciranjem smo glede na posamezne vsebine komuniciranja ugotovili stopnje zadovoljstva, kot so prikazane v tabeli 5.

Tabela 5: Stopnje zadovoljstva glede na vsebine komuniciranja $(n=969)$

\begin{tabular}{|l|c|c|}
\hline Vsebine & $\begin{array}{c}\text { Povprečna } \\
\text { vrednost }\end{array}$ & $\begin{array}{c}\text { Standardni } \\
\text { odklon }\end{array}$ \\
\hline o poslovnem izidu in vrednosti podjetja & 2,54 & 0,991 \\
\hline o lastništvu podjetja & 2,43 & 0,907 \\
\hline o produktih in trgih & 2,48 & 0,924 \\
\hline o (re)organiziranosti & 2,66 & 0,989 \\
\hline o spremembah v vodstvu & 2,57 & 0,975 \\
\hline o kadrovskih zadevah & 2,70 & 0,998 \\
\hline o plačah & 2,94 & 1,153 \\
\hline o možnostih (moje) kariere & 2,83 & 1,104 \\
\hline o zadevah mojega oddelka & 2,45 & 1,051 \\
\hline o varnosti zaposlitve & 2,70 & 1,066 \\
\hline o “izrednih" dogodkih & 2,78 & 0,970 \\
\hline
\end{tabular}


PoSLOVNO KOMUNICIRANJE

M. Ferjan

\section{KRIZNO KOMUNICIRANJE}





\section{VRSTE KRIZ}

Kriza je dogodek, ki se pojavi nenadoma in prizadene organiazcije ali posameznike. Časa nastanka, pojavne oblike, poteka, vpletenih in posledic ni mogoče vnaprej natančno planirati. Kriza je lahko: nesreča, dogodek, stanje, govorica ali samo domneva. Krizo zaznajo notranje in zunanje javnosti ter ciljne skupine organizacije. Zaznava krize vpliva na njihovo percepcijo o organizaciji, sproži čustva ter povzroči negativen odziv. S tem lahko povzroči negativne rezultate za organizacijo.

Krize imajo različne vzroke in s tem tudi različne faze. Različni teoretiki in praktiki tipe kriz razvrščajo na različne načine. Gunning (2012) tako krize razločuje glede na:

- vir krize,

- tip krize in

- krize brez nasilja oziroma z elementi nasilja.

Nadalje ločuje krize, ki jih:

- lahko in bi jih morali predvideti in

- $\quad$ ni mogoče predvideti.

VIR KRIZE:

Narava

Mednarodni dejavniki

Notranji organizacijski dejavniki

Managerji

Zaposleni

\section{TIP KRIZE:}

potres, požar v naravnem okolju, poplava, ... terorizem, vojna, sankcije, ...

škandali, napake na proizvodih, nesreče pri delu, ...

poneverbe, korupcija, klientelizem, prikrivanje ...

napake pri delu, zlorabe, goljufije, žvižgači,

V literaturi obstajajo številne opredelitve različnih kriz in modelov odzivanja nanje. Vendar pa je ključna slabost obstoječih opisov kriz v tem, da modeli kriznega upravljanja in kriznega komuniciranja podajajo sicer uveljavljene, vendar zgolj parcialne rešitve. Coombs (2015) npr. strogo razločuje dva različna tipa kriz:

- Nesreče (npr.: naravne nesreče, prometne nesreče, delovne nesreče, eksplozije, ...).

- Krize percepcije organizacij, katere navadno povzročijo netipični dogodki ali ravnanja. 
Po njegovem so krize zgolj tisto, kar izhaja iz »anomalij« oziroma nepravilnosti. Kriza po njegovem pomeni »napad na ugled organizacije« in s tem izgubo vrednosti za lastnike. Nesreče po njegovem sploh niso krize, ampak samo »dogodki«.

Največ opisov kriz, modelov kriznega upravljanja in kriznega komuniciranja se nanaša prav na krize, ki dejansko ali potencialno povzročijo zmanjšanje:

- ugleda organizacije ali posameznikov;

- zadovoljstva kupcev ali

- zaupanja v organizacijo ali posameznike,

kar posledično pomeni zmanjšanje vrednosti za lastnike oziroma delničarje. Da bi bilo $\mathrm{v}$ resnici okrnjeno zaupanje $\mathrm{v}$ organizacijo in okrnjen njen ugled, morata biti po Benoit-u (2008) hkrati izpolnjena dva pogoja:

- organizacija ali posameznik morata biti dejansko odgovorna za očitano dejanje, in

- dejanje posameznika ali organizacije mora biti žaljivo, neprimerno, ipd.

»Napad« na ugled in zaupanje v organizacijo ali posameznika je torej sestavljen iz dveh delov:

- iz opisa dejanja;

- iz obtožbe odgovornosti za dejanje.

Če dejanje ni žaljivo, ali če ni obtožbe o odgovornosti, potem tudi ni nevarnosti.

Novak (1999) navaja tri tipične značilnosti, ki veljajo za tak tip krize:

- nenadnost (kriza se v medijih pojavi nenadoma);

- negotovost (v času krize ne poznamo vzrokov, nadaljnjega razvoja in posledic);

- časovni pritisk (ukrepati moramo hitro, ne da bi imeli čas za preudaren razmislek).

Po njegovem je učinek krize na organizacijo dvojen:

- vpliva na ugled organizacije $\mathrm{v}$ javnostih;

- tudi dejansko lahko vpliva na poslovanje.

V kontekstu obravnave krize, ki za organizacijo pomeni napad na ugled, se kriza navzven lahko kaže kot:

- prenehanje intenzivnosti ugodne publicitete o organizaciji v medijih;

- nenadna publiciteta o neugodnih dogodkih, ki so se dejansko zgodili, ali pa se morda sploh niso zgodili; 
- drugo.

Ključna naloga kriznega komuniciranja $v$ taki situaciji je ubraniti oziroma povrniti ugled organizacije ali posameznika.

Dogodki, stanja, govorice ali samo domneve, ki vplivajo na zadovoljstvo potrošnikov za organizacijo lahko predstavljajo drugačen tip krize, kot je napad na ugled. Izhajajoč iz temeljnih principov marketinga, mora organizacija zagotoviti zadovoljstvo potrošnikov. Zadovoljstvo potrošnikov je lahko okrnjeno na različne načine in zaradi različnih vzrokov:

- napake na produktih;

- cena (npr.: opažena oderuška cena, kartelno dogovarjanje, izkoriščanje monopola);

- napake pri distribuciji;

- zavajujoče oglaševanje;

- izvajanje storitev s strani nezavzetih ali nekompetentnih zaposlenih;

- pojav ponarejenih izdelkov;

- drugo.

Vzroki za take krize so lahko notranji in zunanji. Notranji vzroki nastanejo v organizaciji. Lahko gre za: slabo vodstvo, nezavzete zaposlene, neustrezen sistem zagotavljanja kakovosti ali napake in pomanjkljivosti tehnologije.

Zunanji vzroki nastanejo izven organizacije. Organizacija na te vzroke nima neposrednega vpliva. Lahko gre za težave pri poslovnih partnerjih ali za objektivne okoliščine.

Ključna naloga kriznega komuniciranja v taki situaciji je ohraniti oziroma povrniti zadovoljstvo potrošnikov.

Obstajajo pa tudi krize, na pojav katerih človek s svojim ravnanjem ne more vplivati. S tem imamo $v$ mislih predvsem naravne nesreče ter tudi druge pojave, pri katerih človekovo zavestno ravnanje ni sprožitveni dejavnik.

V vsaki krizi je pomembno, kako ljudje krizo zaznavajo. Način odzivanja na krizo je treba prilagoditi nevarnosti za življenje in zdravje ljudi in za materialne dobrine ter percepciji in čustvom ljudi. Gre za to, da ljudje različne stvari različno percepiramo. Nekateri krizo ocenjujejo na podlagi racionalnega razmisleka, drugi na podlagi emocij. Za nekatere ljudi je kriza lahko nepomembna, pri drugih pa se kot odziv na zaznavo krize morda pojavijo čustva, kot je stres ali pri skupinah ljudi celo kolektivni stres.

Glede na potreben način odzivanja na krizo torej poznamo:

- krize, pri katerih je napaden ugled organizacije ali posameznika in je naloga kriznega upravljanja in kriznega komuniciranja ohraniti ugled; 
- krize, pri katerih se pojavi nezadovoljstvo strank in je naloga kriznega upravljanja in kriznega komuniciranja ohraniti zadovoljstvo strank;

- nesreče in drugi dogodki, kjer je naloga kriznega komuniciranja ohraniti življenje in zdravje ljudi ter zavarovati kritično in ostalo infrastrukturo;

- krize, kjer se hkrati pojavljajo atributi več tipov kriz.

Ključne naloge kriznega komuniciranja ob nesrečah so:

- zavarovati življenja in zdravje ljudi;

- pomagati telesno poškodovanim;

- pomagati materialno prizadetim;

- zavarovati kritično infrastrukturo;

- zavarovati ostalo infrastrukturo.

Krize se navadno razvijajo po določenih tipičnih fazah. Različni avtorji navajajo različne faze krize, npr.:

- izvor krize oziroma potencialna nevarnost;

- nastanek krize in njena krepitev;

- kritična točka krize;

- zaton (Regester, 1997).

Kot pravi Novak (1999), krize privlačijo medije, pa tudi nasploh ljudi to zanima. Za medije so najbolj zanimive teme: katastrofe, nesreče, terorizem, krize, škandali, konflikti, zločini in korupcija. Tovrstne novice se v medijih dobro prodajajo in javnosti od medijev pričakujejo, da bedijo nad takimi dogodki in jih sproti obveščajo o njihovem poteku. Mediji pa naredijo več, kot le poročajo o krizi. S selekcijo dogodkov določijo, katere bodo obravnavali kot krize, in celo povzročajo nove krize. Do kriz se celo opredeljujejo. Sčasoma pa zadeva postane manj zanimiva, zato se tudi obseg sporočil o krizi zmanjšuje in po nekem času skoraj usahne. Zelo verjetno pa se nekje drugje pojavlja nova zadeva, ki bo zanimiva za medije.

Ne glede na dinamiko razvoja in reševanja dejanske krize v organizaciji mediji posvečajo več pozornosti drugim zadevam. V sami organizaciji so bili dejanski vzroki za krizo odpravljeni, lahko pa tudi ne. Za organizacijo se po prenehanju zanimanja medijev zadeve nekoliko umirijo, nastopi ugodnejši čas za preudaren razmislek in ukrepanje.

$\mathrm{V}$ določenih okoliščinah pa lahko iz poteka predhodnih procesov in dogodkov sklepamo, da se bo zgodilo nekaj slabega za organizacijo. $V$ takih primerih tudi s pomočjo komuniciranja $\mathrm{z}$ javnostmi skušamo doseči objave v medijih in s tem nekatere cilje, kot so:

- priprava ljudi na preudarno in premišljeno ravnanje, če do krize kasneje res pride;

- pridobivanje časa za priprave na pojav »prave« krize; 
- poskus preprečiti kolektivni stres, ki bi lahko nastopil ob nenadnem izbruhu krize.

Najbolj tipično ravnanje je, da postopoma pripravljamo javnosti na možnost izbruha krize, jih osveščamo glede načina odziva in jih pripravljamo na možne posledice. 
Poslovno KomUniciRANJE

Krizno komuniciranje 


\section{KRIZNO KOMUNICIRANJE}

Krizno komuniciranje (Coombs, 2010) lahko opredelimo kot zbiranje, obdelavo in razširjanje informacij potrebnih za reševanje kriznih razmer.

Krizno komuniciranje je ena od ključnih sestavin kriznega upravljanja v širšem smislu. Vsaka kriza ali grožnja namreč ustvarja potrebo po informacijah.

Glede na tip krize obstaja več modelov in strategij kriznega komuniciranja. Za krizo, ki pomeni napad na ugled bomo opisali:

- Strategije kriznega komuniciranja, kot jih opisuje Božidar Novak;

- Image Restoration Theory, katere avtor je William Benoit;

- Situational Crisis Communication Theory, katerea avtor je Timothy Coombs.

Skozi zgodovino so se razvili tudi odzivi na krize, ki pomenijo zmanjšanje zadovoljstva potrošnikov. V Evropi je uveljavljena zakonodaja o varstvu potrošnikov. Zakonodaja $\mathrm{v}$ primeru napak na izdelkih omogoča številne možnosti, katere je dobavitelj dolžan zagotoviti

- vračila kupljenega izdelka v določenem roku;

- uveljavljanje stvarne napake na izdelku;

- garancija;

- ipd.

Številni ponudniki kupcem dražjih izdelkov omogočajo možnost kulance, spet drugi možnost zavarovanja izdelka za primer okvare po preteku garancijske dobe.

Iz zgodovine so poznani tudi številni primeri vpoklica izdelkov na servis z namenom, da se odpravijo tehnične napake ali pomanjkljivosti.

Poleg okvar na izdelkih lahko pride tudi do drugih dogodkov v zvezi z izdelkom in vsem, kar je z njim povezano. V takih primerih se organizacije navadno poslužujejo podobnih strategij kriznega komuniciranja, kot v primeru kriz, ki so po svoji naravi napad na ugled.

Krize, ki so po svoji naravi nesreče, imajo zelo različne pojavne oblike. V Republiki Sloveniji žal na sistemski ravni še ni izdelan celovit komunikacijski načrt kriznega komuniciranja. Ministrstvo za notranjo varnost ZDA - Emergency Management Institute (v nadaljevanju »FEMA $)^{31}$ ima na svojih spletnih straneh javno objavljena številna navodila in priporočila glede postopkov ob različnih nesrečah, gradiva za izobraževanje, ipd. V zahodnem svetu se upoštevajo priporočila FEMA.

\footnotetext{
${ }^{31} \mathrm{https} / / / \mathrm{www} . \mathrm{fema} . \mathrm{gov}$
} 
Krizno komuniciranje v vsakem primeru vključuje aktivnosti:

- pred krizo;

- $\mathrm{v}$ času krize in

- po krizi.

\section{Aktivnosti pred krizo}

Običajno imajo ljudje utečene življenjske ritme. Možnosti pojava krize se sploh ne zavedajo. Kriza pa se lahko pojavi v vsaki organizaciji. Lahko se celo zgodi, da organizacija že doživlja krizo:

- lahko se ji začne zmanjševati obseg prodaje;

- lahko ima opravka z napakami na proizvodih;

- lahko nastopijo težave $\mathrm{v}$ denarnem toku.

Italijanska raziskovalca Mazzei in Ravazzani (2015) sta opravila raziskavo, katere kanale internega kriznega komuniciranja so uporabljali managerji v Italiji v času ekonomske krize, ki se je začela leta 2008. Ugotovila sta, da so mangerji hkrati uporabljali več kanalov. Kar $82 \%$ vprašanih managerjev je kot kanal internega kriznega komuniciranja uporabljalo uradne dopise, e-male zaposlenim in intranet, $75 \%$ pa tudi interpersonalno komuniciranje $\mathrm{z}$ osebjem. Zunanje kanale komuniciranja (npr. tisk in televizijo) je za namene internega kriznega komuniciranja $\mathrm{z}$ zaposlenimi uporabljalo samo $16 \%$ managerjev.

Ton uradnega internega komuniciranja managementa $\mathrm{z}$ zaposlenimi $\mathrm{v}$ času krize je bil: največkrat običajen (44\% odgovorov), najmanjkrat pa čustven (11\% odgovorov). Raziskovalca je tudi zanimalo, katere so bile glavne težave pri notranjem kriznem komuniciranja. Ugotovila sta, da je bila glavna težava managerjev v tem, da so zaposleni imeli različno stopnjo zavedanja krize in trenutnih razmere, ter resnosti vpliva krize. V $56 \%$ primerov se zaposleni sploh niso zavedali resnosti krize.

Ugotovitve Mazzei-ja in Ravazzani-ja (2015), da je bila glavna težava managerjev v tem, da so zaposleni imeli različno stopnjo zavedanja krize, trenutnih razmer in resnosti krize, niso presenečenje.

Ob pojavu ekonomske krize managerji podjetij neposredno zaznajo podatke o obsegu naročil in prodaje ter pokazatelje finančnega poslovanja podjetja. Na osnovi neposrednih zaznav pride do percepcije, ob stikih z managerji drugih podjetij do kognicije in najbrž tudi do pojava čustev zaskrbljenosti, negotovosti in strahu za prihodnost.

Zaposlenim je običajno vsaj v prvem obdobju krize izplačana plača. Managerji za izplačilo plače morda celo najamejo kredit. Zaposleni zato neposredno sploh ne zaznajo simbolov, ki so značilni za krizo. Izplačilo plače lahko celo povzroči percepcijo, da je vse v redu. Od managerjev sicer slišijo in berejo opozorila, da kriza obstaja. Dokler pa sami 
neposredno ne zaznajo simbolov krize, je njihove percepcija stanja v podjetju drugačne, kot pri managerjih.

Osveščanje o možnosti pojava nesreče ali krize zato mora biti permanentna aktivnost vsake organizacije. Vendar zgolj posredovanje izkušenj drugih ne zadošča. Osveščanje je mnogo bolj učinkovito, če ljudje pridobijo lastno izkušnjo.

Ključne za pravilen in pravočasen odziv na krizo so torej aktivnosti organizacije preden se kriza sploh pojavi. Aktivnosti pred krizo so:

- zbiranje informacij o kriznih tveganjih;

- spremljanje opozorilnih signalov;

- preventiva;

- planiranje, kako upravljati potencialne krize;

- vnaprejšnje formiranje kriznega tima in usposabljanje ljudi, ki bodo v primeru potrebe vključeni v proces kriznega upravljanja;

- ostale priprave na možen izbruh kriznega dogodka.

Bistvena naloga $v$ času pred krizo je prevencija. Skoraj ni krize, ki nima vnaprejšnjih opozorilnih znakov. Zato je pomembno stalno prepoznavanje opozorilnih znakov in ključnih akterjev. Če je le mogoče, je treba pravočasno izpeljati aktivnosti, ki preprečijo izbruh krize.

\section{Aktivnosti med krizo}

Gunning (2012) pravi, da tudi če gre za slabe novice, stvari ni dobro prikrivati. Ljudje bodo $\mathrm{v}$ vsakem primeru postavljali vprašanja. Molk je lahko sprejemljiv samo v času poteka sodnih obravnav zaradi strahu pred očitkom vplivanja na sodišče.

O ravnanju med krizo je nekaj besed zapisal tudi Niccollo Machiavelli (1966) v Vladarju , kjer pravi "Vladarji prav gotovo postanejo veliki, kadar so kos težavam, in oviram, ki jim jih ljudje postavijo na pot«.

Organizacije in management se morajo med krizo pravočasno in pravilno odzivati.

Aktivnosti med krizo so:

- zbiranje in obdelava informacij za odločitve kriznega tima;

- izbor strategije za odzivanje;

- ustvarjanje in razširjanje kriznih sporočil v okolje.

Krize v primeru nesreč lahko povzročijo smrtne žrtve in poškodovane. Aktivnost med krizo oziroma odziv organizacije na krizni dogodek je lahko ključen tudi za življenja ljudi. Od tega:

- kdo;

- kdaj; 
- prek katerih kanalov in

- s kakšno vsebino

bo v okolje posredoval sporočila, so pomembno odvisne posledice krize.

Organizacije v krizi in njihove javnosti, ciljne skupine ter deležniki v času krize morajo ohraniti medsebojno zaupanje. Včasih je bolj kot sama vsebina sporočila pomemben izbor kanala, preko katerega bo sporočilo poslano. $V$ času krize je zato izjemno pomembno, po katerih kanalih se pošlje sporočilo in kateremu kanalu oziroma mediju ljudje sploh zaupajo.

Različne študije kažejo, da je primernost posamezne vrste medija odvisna od tipa krize. Posamezni mediji o krizah lahko poročajo tudi spektakularno. Pomembna jim je lahko branost, gledanost in prodaja prostora za oglaševanje, ne pa objektivno poročanje.

Na nekaterih socialnih omrežjih se po drugi strani lahko pojavljajo dezinformacije (»fake news «). Te se do neke mere lahko prepoznajo kot popolnoma izmišljene informacije ali kot »zgodbe«, ki nimajo prav nobene podlage v resničnosti.

Za pošiljanje sporočil mora biti izbran medij, ki mu ljudje zaupajo. Kateremu mediju bodo ljudje zaupali, je odvisno od situacijskih dejavnikov in od vsebine kriznega dogodka.

Po podatkih ameriškega Rdečega križa so socialni mediji za državljane četrti najbolj priljubljen vir za dostop do informacij v času krize ali nesreče. (Stewart, Wilson, 2015). Tako je v času divjanja orkana Sandy v ZDA leta 2012 na družbenih omrežjih informacije iskalo na tisoče državljanov in je bil takrat to eden najpomembnejših medijev za obveščanje.

V krizah drugačnega tipa je lahko drugače. Omilion-Hodges in McClain (2016) sta za raziskovanje anatomije krize uporabili nadzorovan eksperiment $\mathrm{v}$ katerem so razširili nadzorovano govorico (opozorilo) o streljanju v univerzitetnem kampusu. Raziskava je potekala na vzorcu 289 študentov kampusa. Raziskovalce je zanimalo, pri katerem viru bodo študenti najprej iskali informacije o dogodku. $\mathrm{V}$ tem primeru so ljudje najprej iskali verodostojne informacije pri osebnih virih.

\section{Odzivanje na napad na ugled}

V krizah, ki so po svoji naravi napad na ugled, se neugodna publiciteta pojavi nenadoma, vendar imajo take krize praviloma tudi svojo zgodovino in se ne pojavijo čisto nepričakovano.

V svetu je zelo odmeval škandal podjetja Volkswagen v zvezi s testi porabe goriva in emisijami izpustov dizelskih motorjev. Ta škandal je bil javno objavljen $\mathrm{v}$ petek, 18.9.2015. Tega dne je bilo v ZDA objavljeno, da ima 482.000 vozil koncerna 
Volkswagen prirejeno programsko opremo dizelskega motorja, ki se vključi pri testiranju emisij izpušnih plinov.

Ko se je v ponedeljek, 21.9.2015 odprla borza v Frankfurtu v Nemčiji, se je izjemno znižala cena delnic. Skupna izguba delničarjev je znašala več milijard evrov.

Vendar je tudi ta škandal imel svojo zgodovino. Prvi opozorilni znaki so se pojavili že mnogo prej. Že maja 2014 so na testih vozil v Kaliforniji ugotovili, da z izpusti vozil koncerna Volkswagen očitno nekaj ni v redu. Takratni predsednik uprave koncerna Martin Winterkorn naj bi prvo beležko o tem dobil dne 23.5.2014 in dne 14.11.2014 še drugo. ${ }^{32}$ Ta kriza je bila za podjetje Volkswagen torej predvidljiva.

Syme (2014) pravi, da so pri prepoznavanju prvih znakov pojava morebitne krize nedvomno izjemno pomembna tudi socialna omrežja:

1. Socialna omrežja omogočajo odkrivanje opozorilnih znakov ali celo neželenih sporočil, ki potencialno lahko sprožijo krizo.

2. Možna je identifikacija zagovornikov in kritikov organizacije.

3. Možno je prepoznati organizacijsko in institucionalno kulturo in občinstvo.

4. Možno je spremljanje konkurence.

5. Socialna omrežja sooblikujejo trende, etiko in vrednotijo prakse organizacij.

Ko se kriza dejansko pojavi:

- v prvi fazi lahko vpliva na image;

- v drugi fazi lahko vpliva na ugled;

- $\quad \mathrm{v}$ tretji fazi lahko povzroči izgubo zaupanja.

Odziv na krizni dogodek mora:

- $\quad$ v prvi fazi poskrbeti za dober image;

- v drugi fazi preprečiti izgubo ugleda;

- $\quad \mathrm{v}$ tretji fazi ohraniti zaupanje.

Krize, ki so po svoji naravi napad na ugled, pogosto sprožijo žvižgači.

Za izbor ustrezne strategije je pomembno poznavanje:

- ključnih akterjev krize;

- zgodovine dogajanja;

- resničnega stanja, ki naj bi bilo problem;

- stališč ključnih deležnikov;

- stališč in pričakovanih odzivov okolja.

\footnotetext{
${ }^{32}$ Vir: http://www.reuters.com/article/us-volkswagen-emissions-timeline-idUSKBN14V100
} 
Teorija in praksa poznata več strategij kriznega komuniciranja. Različni avtorji jih različno imenujejo in tudi različno opisujejo.

Božidar Novak (1999) razvršča strategije, ki jih slovenska podjetja uporabljajo v praksi komuniciranja v krizi v pet skupin: strategije priznanja in opravičila, strategije pravne pomoči, strategije molka, strategije umika in napada in strategije iskanja širših razlogov za krizo.

Strategija priznanja in opravičila pomeni, da organizacija odgovornost za krizo prizna, se opraviči in "prosi" za še eno priložnost. Izkušnje kažejo, da se ta strategija relativno obnese.

Strategija pravne pomoči se navadno ne obnese. Če namreč neka zadeva pride na sodišče, kriza ne izzveni, pač pa se ob vsaki obravnavi na sodišču pojavi publiciteta. V konflikt vpletene stranke in njihovi odvetniki se najbolj posvečajo iskanju načinov za ugoden izid na sodišču, manj pa za svoj ugled v javnostih.

Strategije molka imajo več pojavnih oblik:

- organizacija se obnaša, kot da ne bi bila vpletena v krizo;

- organizacija zadeve ne komentira;

- organizacija si prizadeva, da zadeva ne bi bila objavljena v medijih.

Strategija molka je slaba. Ljudje iz okolja zaznajo zgolj sporočila medijev, ni pa zaznav sporočil organizacije.

Strategija umika in napada pomeni, da se organizacija (npr.: podjetje) umakne sporen izdelek iz prodaje, kasneje pa se ta spet pojavi.

Strategija iskanja širših razlogov za krizo ima več pojavnih oblik, kot:

- sklicevanje na višjo avtoriteto;

- prenos krivde na nekoga drugega.

Konec 20. stoletja je William Benoit objavil Image Restoration Theory. Ta teorija opisuje strategije kriznega komuniciranja, ki jih organizacija lahko uporabi za obnovitev imagea in ugleda v primeru, če je bil ugled organizacije v krizi res okrnjen.

$\mathrm{V}$ primeru, da sta izpolnjena pogoja:

- da se je neprimerno dejanje res zgodilo;

- da obstaja odgovornost organizacije ali posameznika za tako dejanje

se organizacija ali posameznik morata opravičiti in prevzeti odgovornost. Za prihodnost organizacije je najbolje, da se odgovorna oseba ustno opraviči, prizna krivde in prosi za odpuščanje. 
Ostale strategije kriznega komuniciranja v fazi odzivanja po Benoit-u (2008) pa so še: ZANIKANJE:

- Enostavno zanikanje: »Tega sploh nismo naredili.«

- Krivdno zanikanje: »Tega nismo naredili, če pa je to že kdo naredil, potem nismo bili mi.«

\section{IZOGIBANJE ODGOVORNOSTI:}

- Provokativnost: »Nekdo drug je to naredil.«

- Neizvedljivost: »To se nam ni moglo zgoditi, ker nismo imeli informacij in nadzora nad situacijo.«

- Nenamernost: »To se nam ni zgodilo namerno.«

- Z dobrimi nameni: »To se pač zgodi. Imeli smo dober namen.«

ZMANJŠANJE OFENZIVNOSTI ORGANIZACIJE:

- Krepitev: »Spomnite se pozitivnih lastnosti akterjev in organizacije.«

- Zmanjšanje pomena dejanja: »Zaradi dogodka bo škoda majhna.«

- Diferenciacija: »Poglejte, kako enake ali podobne stvari počnejo tudi drugi.«

- Transcendenca: »Dogodek je treba pogledati v povsem drugem kontekstu.«

\section{ODZIV DO TISTIH, KI PRAVIJO, DA JE KRIZA}

- Odškodnina: »Ponujamo denar ali ugodnosti tistim, ki so bili oškodovani.«

- Korektivni ukrepi: »Obnovili bomo prvotno stanje in obljubljamo, da se dogodek ne bo ponovil.«

\section{PREPREČEVANJE}

- Preprečitev ponovitve akta: organizacija stori vse, da se dogodek ne bi ponovil.

\section{MRTVIČENJE:}

- Mrtvičenje: organizacija naredi vse, da gre dogodek čim prej v pozabo.

Timothy Coombs je avtor teorije Situational Crisis Communication Theory. Coombs (2007 in V Coombs, Holladay, 2010) navaja naslednje strategije kriznega komuniciranja v fazi odzivanja na dogodek, ki sproži krizo:

\section{ZAVRNITVENE STRATEGIJE:}

- Napad tožnika: Krizni manager se sooča z osebo ali skupino, ki trdijo, da je nekaj narobe $\mathrm{z}$ organizacijo.

- Zanikanje: Krizni manager trdi, da ni krize. 
- Grešni kozel: Krizni manager za krizo krivi neko osebo ali skupino zunaj organizacije.

\section{STRATEGIJE ZMANJŠEVANJA POMENA KRIZE:}

- Izgovori: Krizni manager zmanjšuje organizacijsko odgovornost z zanikanjem namena narediti škodo in/ali uveljavlja nezmožnost nadzorovanja dogodkov, ki so sprožili krizo.

- Obrazložitev: Krizni manager zmanjšuje pomen škode, ki jo je kriza povzročila.

\section{STRATEGIJE »PONOVNE IZGRADNJE«:}

- Odškodnina: Krizni manager ponuja denar ali druga nadomestila za oškodovane.

- Opravičilo: Krizni manager navaja, da organizacija prevzame polno odgovornost za krizo in prosi za odpuščanje.

\section{SEKUNDARNO KRIZNO ODZIVANJE}

- Opozorilo: Krizni manager seznanja interesne skupine $\mathrm{z}$ dobrimi deli organizacije.

- Integracija: Krizni manager hvali zainteresirane strani in/ali jih spominja na pretekle skupne uspehe.

- Žrtveno jagnje: Krizni manager opozarja zainteresirane strani, da je žrtev organizacije prevelika.

\section{Komuniciranje ob nesrečah}

Krize, ki so po naravi nesreče, imajo različne pojavne oblike:

- naravne nesreče: potresi, poplave, plazovi, idr.;

- prometne nesreče: na cesti, železnici, na kopnem, v vodi, v letalskem prometu;

- industrijske nesreče;

- nesreče s kemijsko, bakteriološko ali radiološko nevarnimi snovmi;

- večji požari v naravi;

- terorizem;

- drugo.

Kot smo omenili, v Republiki Sloveniji na sistemski ravni žal še ni izdelan celovit komunikacijski načrt kriznega komuniciranja.

Avtorji literature o kriznem komuniciranju ob nesrečah iz zahodnega sveta se večinoma sklicujejo na FEMA. Gre za vsebinsko zelo širok nabor vsebin, kar je posledica tega, da so tudi nesreče po svoji pojavni obliki zelo različne. 
FEMA $^{33}$ ima na svojih spletnih straneh javno objavljene številne ocene ogroženosti, navodila glede postopkov ob različnih nesrečah, gradiva za izobraževanje, ipd. Objavljeni so številni opisi praktičnih izkušenj komuniciranja ob različnih nesrečah v ZDA.

Namen komuniciranja ob nesrečah je:

- pravočasno posredovati ljudem informacije in s tem doseči pripravljenost;

- informiranje o možnosti nesreče, da bi se ljudje znali pravilno odzvati;

- izvajati aktivnosti komuniciranja v času nesreče za ublažitev posledic;

- informiranje po nesreči, da bi se obnovilo stanje pred nesrečo.

Temeljna načela kriznega komuniciranja, kot jih navaja FEMA so:

- Usmerjenost $\mathbf{v}$ uporabnika informacije pomeni, da je ljudem treba posredovati vse informacije, ki so zanje pomembne, ki jih potrebujejo ali želijo.

- Transparentnost pomeni, da delovanje sistema kriznega komuniciranja mora biti pregledno z vidika pristojnosti in odgovornosti.

- Točnost pomeni, da informacije morajo vsebovati zgolj tisto, kar ustreza opisu dejanskega stanja.

- Pravočasnost pomeni, da informacije morajo biti posredovane takoj, ko jih uporabnik potrebuje ali pričakuje, oziroma takoj ko zanje izvemo, oziroma takoj, ko morebitne druge okoliščine to dopuščajo.

- Dostopnost pomeni, da je ljudem treba podati vse informacije po tistih kanalih komuniciranja oziroma tistih medijih, ki jih ljudje ob normalnih razmerah običajno spremljajo, informacije pa je treba podati $\mathrm{v}$ vsakomur razumljivi obliki.

- Partnerski odnos z mediji je treba zagotoviti vnaprej z namenom, da bi mediji pravočasno objavljali točne informacije.

Občinstvo, kateremu so namenjene posamezne informacije je:

- splošna, najširša javnost;

- žrtve nesreče, ki so ljudje, udeleženi v dogodku;

- poslovna javnost, ki jo sestavljajo odgovorne osebe podjetij na območju nesreče;

- mediji;

- predstavniki upravnih organov na območju nesreče;

- predstavniki izvoljenih oblasti na območju nesreče;

- tisti, ki se na nesrečo prvi odzivajo (npr.: gasilci, policija, zdravstvena služba, ...);

- organizacije civilne družbe (npr. Rdeči križ, Karitas, ipd.).

\footnotetext{
${ }^{33} \mathrm{https} / / /$ www.fema.gov
} 
Glede na to, komu je informacija namenjena, se uporabljajo različni kanali komuniciranja. Bistveno pri izbiri kanala komuniciranja je, da:

- v komunikacijskem kanalu ni motenj;

- sporočilo doseže prejemnika;

- se fizično ločijo kanali za profesionalno uporabo (npr.: za policijo, reševalce, idr.) od kanalov za množično obveščanje;

- kanal za komuniciranje s širšo javnostjo velja za »verodostojen « in »transparenten «, torej da kanalu ljudje zaupajo in brez dvomov verjamejo, da ne gre za šalo.

$\mathrm{V}$ primeru predhodnega obveščanja in opozarjanja javnosti na morebitno nevarnost oziroma na izredne dogodke je treba javnost na prihajajoči dogodek pripraviti postopoma. Zato FEMA predlaga 8 stopenj obveščanja:

1. Obvestilo o možnem nastanku izrednega dogodka.

2. Posredovanje verjetnosti, da je nevarnost pojava izrednega dogodka realna.

3. Potrditev, da se bliža nevarnost.

4. Opozorilo ogroženim na nevarnost na način, ki ga zaznajo tudi tisti, ki niso ogroženi.

5. Opozorilo, kateri preventivni ukrepi so potrebni.

6. Opozorilo, katere preventivne ukrepe je treba izvesti.

7. Poziv, naj se izvedejo preventivni ukrepi.

8. Sprejemanje neposrednih ukrepov za zaščito. 


\section{AKTIVNOSTI PO KRIZI}

Vsaka neugodna publiciteta o organizaciji slej ko prej izzveni. Razlog za to je zelo preprost. Tudi če organizacija svojega ravnanja morda ni spremenila, mediji postopoma o zadevi prenehajo poročati. Ljudi to po nekem času enostavno ne zanima več. Prenehanje medijske pozornosti pa ne pomeni, da kriza ni pustila posledic na ugledu organizacije. Zato se s koncem krize aktivnosti organizacije ne smejo prenehati. Takoj je treba pristopiti $\mathrm{k}$ aktivnostim za ponovno izboljšanje ugleda, predvsem pa k vzpostavitvi zaupanja.

Aktivnosti po krizi so torej naslednje:

- $\quad$ preverjanje, če je krize dejansko konec;

- analiza izvedenih aktivnosti v času krize;

- preverjanje, če je bil odziv javnosti pozitiven oziroma, če je bila preprečena še večja škoda;

- izvedba potrebnih sprememb v organizaciji;

- popravljanje ugleda.

Treba je vedeti, da so se skozi zgodovino krize dogajale tudi najbolj uglednim podjetjem. Vendar so se podjetja v zgodovini kriz med seboj razlikovala po tem, kakšni so bili popravljalni ukrepi. Marsikatero podjetje je zaradi krize propadlo. Po drugi strani pa obstajajo številni primeri, ko so podjetja zmogla opraviti kritično analizo in iz krize izšla še močnejša. Podobno velja za nesreče. Ko nesreča mine, je treba pristopiti k ukrepom sanacije posledic.

Če je šlo za krizo zadovoljstva potrošnikov, je potrebno v prvi vrsti preprečiti, da se škodljivi dogodki ponovijo. Zato je potrebno opraviti temeljito analizo celotnega marketinškega spleta in ugotoviti, pri katerem elementu je bil problem. Seveda je treba izvesti popravljalne ukrepe. Organizacije, ki želijo biti do svojih odjemalcev prepričljive, $\mathrm{v}$ primerih, ko so se pojavile težave $\mathrm{s}$ produktom, pripravijo izboljšave obstoječih produktov.

Šolski primer je dogodek, ki se je zgodil 21. oktobra 1997. Tega dne je novinar Robert Collin preiskušal stabilnost vozila Mercedes razreda A, na tako imenovanem »lososovem testu «. Test je sicer standardiziran s standardom ISO 3888-2. Na tem testu se je vozilo Mercedes prevrnilo, kar je bilo za podjetje prava sramota. O tem so poročali vsi svetovni mediji. Proizvajalec vozil je opravil analizo dogodka. V ta vozila je začel serijsko vgrajevati številne nove varnostne sisteme. Vpoklical je tudi vsa že prodana vozila in jih tehnično nadgradil. sVozilo je kaneje postalo prodajna uspešnica. Podjetje ni utrpelo nobenih posledic, pač pa je na dolgi rok imelo celo dobiček. 
Za bodočnost je treba pripraviti tudi druge marketinške ukrepe, ki bodo ohranili lojalnost obstoječih strank in morda celo pritegnili nove. Ti ukrepi imajo največkrat naravo posebnih ugodnosti pri naslednjem nakupu.

Podobno velja za krize, kjer je bil okrnjen ugled. V poglavju, kjer smo obravnavali image organizacije, smo navedli dimenzije image-a: legitimnost, pravilnost in doslednost, zanesljivost in ugled. Če je v organizaciji dejansko šlo nekaj narobe, mora po krizi organizacija začeti spreminjati svojo identiteto. V okolje mora poslati jasna sporočila o tem, da so ji pomembne družbeno sprejete norme, vrednote in pričakovanja okolja.

Če so bile razlog tehnične napake v delovanju organizacije ali posameznikov, je treba v javnosti poslati sporočila o popravljalnih ukrepih $\mathrm{z}$ vidika nadgradnje kompetenc.

Prepričanja in pričakovanja ljudi so pogosto povezana s podobami o vodstvu organizacije. Pravilnost pa je atribut image-a, ki se nanaša na vodstvo. Zato organizacije morajo same oceniti, na kakšen način ta pričakovanja uresničiti. 



\section{KAJ SO POGAJANJA}

Pogajanja so poskus usklajevanja nasprotnih položajev z namenom doseči sprejemljiv učinek za obe strani.

Da se pogajanja sploh začnejo, je potrebno dvoje:

- predmet spora (oziroma predmet pogajanj) in

- skupni interes (Vukadinović, 1994).

Vsaka pogajanja imajo tri glavne atribute:

- pogajalske strani;

- pogajalski proces in

- rezultat pogajanj.

Pogajanja so proces, v katerem se predstavljajo eksplicitni predlogi za sklenitev sporazuma.

Liu (2014) postavlja zelo zanimivo definicijo ko pravi, da so pogajanja interakcija med dvema ali več partnerji, ki imajo različno percepcijo ciljev.

Pogajanja so torej eden od načinov zadovoljevanja potreb različnih strani. Eno osnovnih načel pogajanj je, da morata s pogajanji obe strani nekaj pridobiti. Če nekdo nenehno izgublja, se lahko zgodi, da se bo za daljši čas umaknil čim dlje od nas. Če pa je izguba le prehuda, se pogosto zgodi, da partner razmišlja le, kako nas bo premagal.

Pogajanja ljudje pogosto napačno razumejo kot prodajanje oziroma kot tekmovanje. Razlika med pogajanji in prodajanjem je v tem, da ob koncu pogajanj obe strani morata pridobiti občutek, da sta pridobili točno tisto, kar sta želeli. Pri prodajanju pa je drugače. Prodajalec mora prepričati kupca, da npr.: kupi točno določeni izdelek po točno določeni ceni. Pri pogajanjih se obe strani zavedata, da gresta na pogovor, ne da bi nujno želeli kaj prodati ali kupiti, ampak, da bi dosegli najboljši izid. Dogovorjeno mora ustrezati obema. Bistvena razlika med pogajanji in tekmovanjem je $\mathrm{v}$ tem, da se ob koncu pogajanj nobena stran ne sme počutiti niti kot zmagovalec, niti kot poraženec. Pred tekmovanjem so pravila igre točno določena, pri pogajanjih pa si pravila igre lahko sproti določamo.

Vsaka pogajanja so si med seboj popolnoma različna. Načeloma sicer obstajata dva tipa pogajanj:

- Distributivna pogajanja so tista, pri katerih se pogajamo o neki fiksni stvari, katero je treba razdeliti. Taka pogajanja so npr. pogajanja o plačah v javnem sektorju. 
- Integrativna pogajanja so tista, katerih rezultat je lahko možnost dobička za obe pogajalski strani, vendar je potrebno reševanje problemov, usklajevanje in izmenjava informacij. Taka pogajanja so npr. pogajanja o sklenitvi koalicijske pogodbe po volitvah.

Poleg integrativnih in distribucijskih vidikov pogajanj je lahko eden od pomembnejših ciljev tudi graditi pozitivne odnose za prihodnost in ohranjanje ugleda organizacije.

Ker so vsaka pogajanja unikatna, poteka pogajanj nikoli ni mogoče opisati z algoritmi ali matematičnimi formulami. Različni avtorji na različne načine členijo potek priprav na pogajanja. Različno opisujejo tudi pogajalske taktike. Razlog različnih pristopov k opisovnaju pogajanj je $\mathrm{v}$ tem, da so posamezni avtorji izhajali iz zelo različnih konkretnih pogajanj. Različni avtorji raziskav so preučevali pogajanja:

- $\quad \mathrm{v}$ različnih okoljih;

- med različnimi pogajalskimi stranmi;

- glede različnih vsebin;

- v različnih kontekstih ter

- v različnih časovnih obdobjih.

Kljub vsem razlikam v vsebini pogajanj, njihovih kontekstih in zelo različnih časovnih obdobjih, pa vendarle obstajajo nekatera univerzalna spoznanja. 


\section{PRIPRAVE NA POGAJANJA}

Nikoli in v nobenih okoliščinah se ne smemo začeti pogajati slabo pripravljeni ali celo nepripravljeni. O tem, da so priprave ključna faza za uspešna pogajanja ni prav nobenega dvoma. Staro pravilo pravi, da uspejo le tiste stvari, ki so pripravljene. Liu (2014) navaja, da so številne študije pokazale, da je potrebno vsaj $\mathbf{8 0 \%}$ od vsega vloženega truda vložiti v priprave na pogajanja.

Če so pogajanja omejena na nek določen čas, ali pod časovnim pritiskom, je še bolj pomembno, da so priprave temeljite.

Slaba pripravljenost ene ali obeh pogajalskih strani povzroči številne neugodne posledice:

- podaljšuje trajanje pogajanj;

- poveča verjetnost popuščanja;

- zmanjša verjetnost, da bomo dosegli cilj;

- povečuje verjetnost, da bodo pogajanja mučna, iskanje rešitev pa težje, kot bi bilo potrebno.

Pogajanja ne bi bila pogajanja, če med samim potekom pogajanj ne bi prišlo do novih stanj in procesov, ki so bili pred začetkom pogajanj za eno ali obe strani nepoznani. Priprave na pogajanja zmanjšajo možnost, da bi se med samim potekom pojavile nove neznanke. Če do njih pride, dobra priprava oslabi njihov vpliv.

Različni avtorji različno klasificirajo procese priprav na pogajanja. Posamezni avtorji dajejo različnim aktivnostim različen pomen. Vsem avtorjem je nekako skupno, da priprave vključujejo naslednje aktivnosti:

- spoznavanje konteksta problema;

- definiranje ciljev pogajanj;

- zbiranje potrebnih informacij;

- izbira pogajalcev;

- priprave na uspešno komuniciranje;

- načrtovanje poteka pogajanj.

\section{Spoznavanje konteksta in strukture problema}

Liu (2014) pravi, da je najprej potrebno spoznati celoten kontekst in strukturo problema o katerem se pogajamo. 
Spoznavanja konteksta pomeni, da je treba oceniti:

- Zgodovinski, politični, pravni in kulturni kontekst, v katerem bodo pogajanja potekala.

- Namen pogajanj: Če gre za poslovna pogajanja, pogajalci navadno uporabljajo razdelitvene strategije in dajejo zahtevke glede vrednosti. Lahko pa gre tudi za integrativna pogajanja.

- Naravo spora: Vprašati se je treba, ali so v problem vključena čustva ali ideologije in če imajo pogajalci druge strani bistveno drugačne moralne standarde, vrednote in prepričanja, kot mi.

- Trajanje pogajanj: Gre za vprašanje, ali gre za enkratna pogajanja, ali za daljša pogajanja.

- Dostikrat je tako, da se $\mathrm{v}$ življenju in poslu znova in znova srečujemo $\mathrm{z}$ istimi ljudmi. Treba je upoštevati tudi to, da pogajalci izvirajo iz »skupne socialne mreže«. Če imajo ljudje »relacijske zgodovine» obstaja možnost njihovega vpliva na potek pogajanj.

- Časovni pritisk: Če situacija zahteva hitre rešitve, je večja verjetnost, da bodo priprave na pogajanja pomanjkljive in da bo prišlo do iracionalnih potez pogajalcev.

- Kraj pogajanj: Pogajanja lahko potekajo na domačem terenu, na nasprotnem terenu ali na nevtralnem terenu. Vsaka od možnosti ima svoje prednosti in slabosti. Prednosti pogajanj na domačem terenu so:

- pogajalci poznajo prostor, navajeni so ga in ga psihično obvladajo;

- doma je dostopnost novih informacij večja, kot kjerkoli drugje;

- ker se na kraj pogajanj ne prevažamo, smo na začetku lahko točni in spočiti, $\mathrm{v}$ premorih pa imamo priložnost za počitek;

- prometno sredstvo, ki ga uporabi nasprotna stran, nam lahko marsikaj pove o njej.

Tudi pogajanja na nasprotnikovem terenu imajo svoje prednosti:

- na podlagi opremljenosti poslovnih prostorov, urejenosti sodelavcev in opazovanja medsebojnih odnosov lahko sklepamo o marsičem;

- sprejem nam pokaže odnos nasprotne strani do nas;

- iz simbolike odnosa sodelavcev pogajalca nasprotne strani do njega so možna pomembna sklepanja;

- nimamo skrbi za tehnično pripravo pogajanj.

- Uporaba komunikacijskih kanalov: V pogajanjih se poleg osebnih srečanj uporabljajo tudi različni komunikacijski kanali (npr, telefon, videokonference, e-pošta, hitra sporočila). Gre za vprašanje zaupanja v kanale in morebitno zlorabo sporočil, poslanih po komunikacijskih kanalih. 
Spoznavanje strukture problema pa pomeni:

- Identifikacijo stranke $\mathbf{v}$ pogajanjih. $\mathrm{V}$ okviru nekih pogajanj ali nekega konflikta se sicer lahko pogajamo $\mathrm{z}$ neko stranko, ki je $\mathrm{v}$ zadevo vpletena. Vendar je možno, da so v zadevo posredno ali neposredno vpleteni tudi drugi, s katerimi pa se ne pogajamo. Če se vlada npr. pogaja s sindikatom zdravnikov, so $\mathrm{v}$ isto strukturo problema vključeni tudi drugi sindikati, npr. sindikat učiteljev. Čeprav te stranke niso prisotne na pogajanjih, pa na rezultat pogajanj posredno vplivajo.

- Identifikacija vprašanj pogajanj: Pogajamo se lahko samo o enem ali o več vprašanjih. Vlada in sindikati se lahko pogajajo samo o enem vprašanju (npr. o plačah), lahko pa o več vprašanjih (npr.: o številu dni dopusta, o trajanju tedenske delovne obveze, o pravici do izobraževanja zaposlenih, ipd.).

- Identifikacija interesa pomeni spraševati samega sebe, kaj nekdo sploh želi. $\mathrm{Ni}$ nujno, da je interes, ki ga neka pogajalska stran javno deklarira v medijih, tudi njen dejanski interes. Pravi interes je lahko nekaj drugega. Ne smemo pozabiti, da je možen interes lahko tudi ohranitev »status quo«. »Status quo« pomeni ohranitev stanja, ko se nič ne spremeni.

- Identifikacija razlogov za interes pomeni spraševati samega sebe, zakaj si nekdo nekaj želi. Poznavanje interesa in razlogov za interes bistveno vpliva na potek pogajanj. Razlog, ki ga nekdo navzven deklarira kot svoj interes, je lahko:

- dejanski obstoj nekega problema;

- zgolj namišljen problem.

Kakšna poklicna skupina ima morda res lahko prenizke plače. V tem primeru vlada lahko išče dodatne možnosti za pogajanja in alternativne rešitve, ki ne podirajo celotnega sistema. Razlog za interes pa je lahko zgolj v tem, da sindikati pač morajo upravičiti prejemanje članarine od svojih članov.

\section{Zbiranje potrebnih informacij}

Viri informacij za spoznavanje konteksta neke zadeve so:

- spoznavanje zgodovine neke zadeve;

- lastne izkušnje;

- izkušnje drugih;

- ocena bonitete poslovnega partnerja oziroma poslovnega tveganja pri poslovanju z njim;

- publikacije zunaj podjetja;

- mediji;

- drugo.

Že stoletja velja pravilo, ki pravi, da si je izkušnje o poslovanju s posameznimi partnerji treba zapisovati. Na ta način si sistematično ustvarimo evidenco o poslovanju s partnerji, 
o njihovih poslovnih in pogajalskih manirah. Dostikrat so zelo dragocene zabeležke o drobnih, navidez nepomembnih dogodkih.

Podatke je mogoče pridobivati tudi od drugih. Pri tem je zelo pomembno, da vzpostavimo in vzdržujemo čim širšo mrežo osebnih poznanstev.

O posameznih poslovnih subjektih je iz različnih virov mogoče pridobiti zelo različne podatke.

Določene informacije o pogajalskem partnerju lahko pridobimo iz javnih virov. Informacije pridobimo tudi med samim potekom pogajanj. Poznani sta dve metodi:

- opazovanje simbolov;

- aktivno spraševanje.

Najbolj pomembno je spremljati neverbalne simbole, ker so večinoma izven zavestnega nadzora pošiljatelja.

Kljub vsem virom in metodam pridobivanja podatkov, na vsa vprašanja ne moremo pridobiti odgovorov. Vedeti moramo, da o nas zbira podatke tudi nasprotna stran. Zato moramo upoštevati, da so določene informacije poznane le nam, določene samo drugi pogajalski strani, določene pa obema stranema. Upoštevati moramo tudi možnost, da med samimi pogajanji lahko pride do sprememb ključnih dejstev tako na eni, kot na drugi pogajalski strani.

\section{Definiranje ciljev pogajanj}

Pred začetkom pogajanj moramo vnaprej vedeti, kaj s pogajanji želimo doseči, oziroma kaj je naš cilj. Cilj je želeno stanje, katerega naj bi dosegli po koncu pogajanj. Cilj je tudi osnova za presojo uspešnosti pogajanj. Oblikovaje ciljev pogajanj vsebuje:

- oblikovanje in definicijo »spremenljivk;

- rangiranje pomembnosti posameznih spremenljivk po hierarhiji;

- opredelitev pogajalskega intervala.

Prvi korak pri definiranju ciljev pogajanj je oblikovanje spremenljivk. To pomeni, da je celoto treba strukturirati na razumno število posameznosti, ki so med seboj povezane in skupaj tvorijo celoto. Posameznostim je treba definirati konkreten pomen. Če se vsebina pogajanj nanaša na plače, ima $v$ vsaki organizaciji celokupni letni strošek dela omejitve ekonomske narave, preko katerih delodajalec enostavno ne more. S sindikati se ni mogoče pogajati o strošku dela kot celoti, zato je »plačo « treba strukturirati na sestavine: osnovna plača, dodatek za oceno uspešnosti delavca, dodatek za uspešnost poslovanja podjetja, regres za dopust, odpravnine, jubilejne nagrade, ipd. Vsaki od spremenljivk je treba opredeliti pomen.

V naslednjem koraku moramo postaviti ciljno strukturo oziroma hierarhijo ciljev. To je razvrstitev ciljev po pomembnosti. Opredeliti moramo, pri katerem cilju je dopustno 
popustiti, da bi dosegli nek drug cilj. Razmisliti moramo, kaj je za nas pomembno in kaj nepomembno. V fazi snovanja ciljev je treba opredeliti, pri katerem od ciljev popuščanja nikakor ne bo. Morda je pomembno, da želimo bolj nagraditi uspešne delavce, torej bomo spremenljivki »dodatek za oceno uspešnosti delavca « pripisali večji pomen. V kasnejšem procesu pogajanj bomo pri tej spremenljivki manj popuščali, kot pri spremenljivkah, ki smo jim pripisali manjši pomen.

Opredeliti je treba tudi posledice nedoseganja ciljev pogajanj. Pogajanja se navadno končajo uspešno, ko obe pogajalski strani dosežeta svoje cilje, oziroma propadejo, če ena stran zahteva več, kot je druga pripravljena popustiti.

Za dosego ciljev pogajanj je bistveno varovanje podatkov oziroma čuvanje skrivnosti. V fazi snovanja ciljev je nujno, da opredelimo, kateri podatki so zapni, kakšna je stopnja zaupnosti in kako ohraniti zaupnost.

Za vsak cilj posebej določimo pogajalski interval. To je ena najbolj varovanih pogajalskih skrivnosti. Cilje je treba opredeliti kot stanja. Pogajalski interval je stanje ciljev in sicer:

- Zgornja točka je tisto ciljno stanje, ki je za nas najbolj ugodno.

- Realna točka je tisto ciljno stanje, katerega bomo najbolj verjetno tudi dosegli.

- Spodnja točka je tisto ciljno stanje, ki predstavlja najmanj, kar še lahko sprejmemo.

S pogajalskim intervalom si določimo stopnjo popuščanja. Pomembno je, da je med točkami zadosten razpon, da v pogajanjih lahko postopno popuščamo. Pri določanju zgornje točke je najbolj pomembno, da si jo postavimo zadosti visoko, vendar realno. To je tudi element pri izbiri taktike pogajanj. Zgornja točka naj bo stanje, ki je bolj ugodno od tistega, katerega nameravamo doseči s pogajanji. Če na pogajanjih ne dosežemo niti spodnje točke, s pogajanji prenehamo.

Doseči manj od spodnje točke je nesprejemljivo. Če na pogajanjih ne dosežemo niti spodnje točke, s pogajanji prenehamo. Že v pripravah na pogajanja je treba opredeliti verjetnost, da do tega pride. Če je verjetnost velika, je treba vnaprej poiskati rezervni scenarij.

\section{Izbira pogajalcev}

Prvo knjigo o pogajanjih je leta 1716 napisal francoski diplomat Francois de Callieres. V njej je zapisal, da je usoda največjih držav pravzaprav odvisna od njihovih pogajalcev. Pogajalce je treba zelo skrbno izbrati. Nihče ni kar avtomatsko vnaprej primeren za pogajanja, niti ni vnaprej neprimeren. Pogajalca oziroma pogajalce se izbere na osnovi številnih dejavnikov:

- osebnost pogajalca;

- socialni kapital; 
- relacijska zgodovina;

- spol;

- poznavanje vsebine pogajanj in »tehnično« znanje o vsebini;

- osebni interes;

- izkušnje;

- pojavne oblike in intenzivnost čustvenega odzivanja na zaznave;

- poznavanje kulturnega okolja;

- drugo.

Najprej se je treba odločiti, ali se bo pogajal en sam pogajalec, ali pa pogajalska skupina. Oboje ima svoje prednosti in slabosti.

Prednosti, če se pogaja posameznik so:

- Če se pogaja posameznik, ni šibkega člena. Šibki člen pomeni, da je eden od članov skupine v eni od zahtevanih lastnosti pogajalcev slabši.

- Posameznik lahko takoj sprejme odločitev, če je to $\mathrm{v}$ mejah njegovih pooblastil.

- Za dosego ciljev pogajanj je odgovorna samo ena oseba.

- V skupini lahko obstaja nekohezivnost, kar praviloma zelo slabi položaj.

Prednosti pogajalske skupine pa so:

- V skupini so lahko zastopani specialisti določenih strokovnih področij.

- Člani pogajalske skupine se lahko med seboj posvetujejo.

- Intelektualni in socialni kapital skupine je večji.

- Pogajalska skupina omogoča uporabo različnih pogajalskih taktik.

Prva, ki sta opravljala raziskovanja o tem, kako človekova osebnost vpliva na rezultate pogajanj, sta bila Walton in McKersie leta 1965. V tej knjigi smo že opisali, da človekovo osebnost sestavljata temperament in značaj. Kot pravita Stuhlmacher in Adair (2014), je osebnost pogajalca zelo pomembna za izid pogajanj. Ključna ugotovitev z vidika primernosti osebnosti pogajalcev je bila, da je treba opraviti analizo primernosti temperamenta in značaja kandidatov za pogajalce glede na to, ali gre za distributivna pogajanja, integrativna pogajanja ali za graditev pozitivnih odnosov za prihodnost. Vpliv osebnosti se odraža na behaviorizmu pogajalca med pogajanji. Gre za vprašanje, kakšen bo odziv pogajalca na zaznave med pogajanji. Odzivi na različne zaznave tekom pogajanj seveda vplivajo na končne rezultate pogajanj.

Avgar in Lee (2014) menita, da je ključni element pri izbiri pogajalcev »socialni kapital «. Socialni kapital izhaja iz mreže medčloveških odnosov, ki jih ima posameznik v okolju. Socialni kapital ima lahko pomembne posledice za izid pogajanj. Prednosti pogajalcev z večjim socialnim kapitalom sta:

- večja možnost dostopa do informacij; 
- moč in večji vpliv pogajalcev.

Poleg tega je dokazano, da so pogajalci z večjim socialnim kapitalom v procesu pogajanj bolj kreativni. Prav tako je dokazno, da so bolj solidarni, kar pomeni možnost hitrejše rešitve problemov.

V poslovnem svetu in politiki pogajalci zelo pogosto izvirajo iz »skupne socialne mreže«. Če imajo ljudje »relacijske zgodovine« je treba ugotoviti, če obstaja možnost vpliva na potek in rezultate pogajanj. $\mathrm{V}$ zgodovini so bili številni primeri tako pozitivnih, kot negativnih vplivov relacijskih zgodovin na pogajanja.

Paddock-ova (2014) se sklicuje na rezultate raziskovanj zadnjih desetletij in pravi, da ženske glede na moške pogosto pomenijo slabost pri pogajanjih. Vendar slabost ne izvira iz spola, pač pa iz moških stereotipov o ženskah, ki so se razvili skozi stoletja. V nasprotju s temi ugotovitvami so iz zgodovine poznani številni primeri, ko so bile uspešne pogajalke prav ženske.

Pogajalec mora imeti zadostno »tehnično« znanje o vsebini pogajanj. O vsebinskih vprašanjih se lahko pogajajo le ljudje, ki te vsebine poznajo, zaželeno je, da vsaj v grobem poznajo tudi zgodovinski kontekst.

V pogajanjih o združevanju političnih strank, sestavi vlad, združevanju podjetij in sestavi uprav se je že marsikdaj postavilo vprašanje, če nek pogajalec zastopa interes organizacije ali zgolj svoj osebni interes. Številna, zlasti integrativna pogajanja so propadla izključno zaradi osebnih interesov pogajalcev.

Pogajalec z zelo veliko izkušnjami lahko pomeni prednost, lahko pa tudi slabost. Lahko predstavlja priložnost, lahko pa tudi nevarnost.

Obstaja večja verjetnost, da so izkušeni pogajalci podvrženi stereotipom. To lahko predstavlja nevarnost, da ne bo prišlo do dogovora. Po drugi strani pa je to lahko tudi priložnost; druga stran izkušene pogajalce namreč pozna in se nanje in na njihove stereotipe pripravi. Zato izkušen pogajalec lahko vnaprej pripravi svoje predloge in odzive »izven konteksta starih stereotipov, « ki jih druga stran ne pričakuje.

Pri popolnoma neizkušenem pogajalcu obstaja večja verjetnost čustvenega odzivanje na zaznave, kot pri izkušenem.

$\mathrm{Na}$ to, da univerzalno veljavnih pravil uporabe pogajalskih taktik ni, kažejo tudi rezultati raziskave, katero so leta 2007 objavili Wolfgang Steinel in soavtorji. Zanimalo jih je:

- če se ljudje z izkušnjami naučijo biti boljši pogajalci in

- če izkušnje pogajalcev in nasveti zunanjih svetovalcev vplivajo na dosego ciljev.

Opravili so znanstveni poskus na vzorcu 140 udeležencev. Da bi udeležence v eksperimentu dodatno motivirali za sodelovanje, so jim za uspeh pri pogajanjih ponudili 
tudi denarne nagrade. Ugotovili so, da niti izkušnje pogajalcev, niti nasveti zunanjih svetovalcev neposredno ne vplivajo na dosego ciljev pogajanj. So pa ugotovili, da so ljudje z izkušnjami bolj natančni. To je možno interpretirati tudi $\mathrm{s}$ tem, da so vsaka pogajanja drugačna od predhodnih.

Tudi med kulturami obstajajo velike razlike. Gülçlimen in soavtorji (2010) so v Turčiji preučevali razlike in podobnosti med pogajanji $\mathrm{v}$ domačem in mednarodnem poslovnem okolju. Prepoznali so pomembne razlike v medosebni privlačnosti pogajalcev. Zanimivo pa je, da se se pokazale tudi razlike $\mathrm{v}$ interpretaciji istih informacij. Kadar pogajanja potekajo v multikulturnem okolju, je treba izbrati pogajalca, ki pozna in razume kulturo obeh pogajalskih strani.

\section{Priprave na uspešno komuniciranje}

Pogoj za uspeh pogajanj je sposobnost medsebojnega komuniciranja. To velja tako za komuniciranje med člani pogajalske skupine, kot za vzpostavljanje interakcij z drugo pogajalsko stranjo.

Za uspešna pogajanja je potrebno pripraviti vse materiale, katere bodo potrebovali pogajalci.

Če gre na pogajanja pogajalska skupina, se člani skupine morajo medsebojno uskladiti glede (predvsem strokovne) terminologije, katero bodo uporabljali. Prav tako se morajo dogovoriti o uporabi "govorice telesa" za medsebojno sporazumevanje. Med člani pogajalske skupine mora biti kohezivnost.

Eno pomembnejših vprašanj vsakih pogajanj se nanaša na formalnost in neformalnost komuniciranja. Izkušnje po eni strani dokazujejo izjemen pomen neformalnega komuniciranja za uspeh pogajanj. Po drugi strani pa neformalno komuniciranje lahko predstavlja veliko nevarnost za uhajanje informacij.

\section{Načrtovanje poteka pogajanj}

Po tem, ko smo opredelili kontekst in problem pogajanj, ko poznamo vsebino pogajanj, ko smo določili strukturo in hierarhijo ciljev ter pogajalske intervale ter izbrali pogajalce, se začnemo ubadati z vprašanjem, kako doseči cilje pogajanj. Odločiti se moramo o strategiji pogajanj. Strategija pogajanj pomeni iskanje odgovorov na vprašanja:

- S kakšno dinamiko se bomo pogajali o posameznih zadevah?

- Ali se nam mudi, ali je ugodneje, da počakamo?

- Ali bomo zavlačevali ali pa skušali čim hitreje najti rešitev?

- Po kakšnem vrstnem redu bomo skušali dosegati cilje?

- S kakšno dinamiko se namerava pogajati nasprotna stran?

- Ali se nasprotni strani mudi, ali ne?

- Kakšni so pogajalski intervali nasprotne strani?

- Po kakšnem vrstnem redu bo nasprotna stran skušala dosegati svoje cilje; 
- S katerimi ukrepi in načinom pogajanj bomo nasprotni strani prikrivali naše cilje in strategije?

- na kakšen način bomo pisali zapisnik?

- Kakšen bo naš odnos do javnosti?

Strategijo določimo na podlagi poznavanja naše in partnerjeve (nasprotnikove) ciljne strukture in strategije pogajanj. O nasprotni strani imamo le omejeno količino informacij, saj je temeljno pravilo uspešnih priprav skrivanje ciljev oziroma strategij.

Šele, ko se pogajanja začnejo, se pokaže, koliko so bila naša predvidevanja pravilna. Zato morajo biti pogajalske strategije dovolj prožne.

Slatkin (2015) opozarja, da je že vnaprej treba razmisliti o možnih napakah pri pogajanjih. Pravi, da so zelo veliko športnih lovorik osvojili tekmovalci, ki pred tekmovanjem sploh niso veljali za favorite ali so bili morda celo v povsem izgubljenem položaju. Takim primerom smo bili priča tudi v Sloveniji. Discipliniran igralec povprečnih sposobnosti lahko porazi nekoga, ki sicer velja za boljšega, hitrejšega ali močnejšega. Zmaga zato, ker stori manj napak. Možne napake v pogajanjih so:

- slabe priprave na pogajanja;

- napake pri izboru pogajalca;

- iracionalna pričakovanja;

- pričakovanje zmage za vsako ceno;

- zanemarjanje pozornosti za odnose s pogajalskimi partnerji;

- napake, povzročene zaradi čustvenih reakcij pogajalcev;

- pretirano obveščanje javnosti o poteku pogajanj;

- nasprotujoče si vsebine obveščanja javnosti s strani pogajalskih strani;

- nejasnost pooblastil pogajalcev;

- izostanek dogovora o poslovniku pogajanj;

- notranja neenotnost pogajalskih skupin;

- preveč očiten osebni interes pogajalcev;

- pomanjkanje osebne presence pogajalca.

Preden začnemo s pogajanji, je treba vnaprej predvideti, kakšen bo odnos do javnosti. Živimo v času demokracije in zahtev po javnosti delovanja organizacij. Če so pogajanja javna, to za pogajalce predstavlja omejitev in dodaten pritisk. To podaljša trajanje pogajanj in zmanjša verjetnost uspeha.

Včasih je za uspeh pogajanj bolje, da javnost ni seznanjena s tem, da pogajanja sploh potekajo.

Pogajanja lahko potekajo tudi "za zaprtimi vrati", kar pomeni, da je javnost seznanjena zgolj s tem, da pogajanja potekajo. 
Poslovno KomUniciRANJE

Pogajanja 


\section{IZPELJAVA POGAJANJ}

Za začetek pogajanj je potrebna pobuda. Lahko se zgodi, da sta pogajalski strani različno zainteresirani za začetek pogajanj. Začetek pogajanj ena od strani lahko namenoma zavlačuje $\mathrm{z}$ argumentom, da niso rešena tehnična vprašanja. Pogoj za začetek pogajanj so rešena tako imenovana tehnična vprašanja. Gre za uskladitev obeh pogajalskih strani glede časa, kraja, teme in ciljev pogajanj ter za opredelitev odnosa do javnosti.

Ko so rešena tehnična vprašanja, lahko pride do začetka pogajanj. Na začetku pogajanj najprej pride do predstavitve pogajalcev. Sem sodi tudi predstavitev pristojnosti pogajalcev oziroma pogajalskih skupin. Pogajalski strani morata vedeti, kakšna so njuna pooblastila. Sklicevaje na omejenost pooblastil je namreč ena od pogajalskih taktik.

Kadar gre za pogajanja o kompleksnejših zadevah (npr. med vlado in sindikati) je za nadaljnji potek ugodno, da se takoj na začetku sprejme poslovnik pogajanj. V poslovniku se opredeli:

- vsebina pooblastil pogajalcev;

- način sklicevanja sestankov;

- način določanja dnevnega reda;

- način sprejemanja sklepov oziroma zaključkov;

- način pisanja zapisnika;

- način potrjevanja zapisnika;

- način zaključevanja točk dnevnega reda;

- odnos do javnosti;

- drugo.

Naslednja faza $v$ pogajanjih je določitev dnevnega reda. Pri tem že lahko pride do "pogajanj" o samem dnevnem redu. 
Pogajanja 


\section{POGAJALSKE TAKTIKE}

Pogajalske taktike so vsa dejanja pogajalcev med procesom pogajanj, katerih se pogajalske stani poslužujejo, da bi dosegle svoje cilje.

Saee (2008) loči: verbalne, neverbalne in situacijske taktike.

Verbalne taktike so: obljube, grožnje, priporočila, opozorila, prepričevanja, nagrade, kaznovanja, postavljanje pravil, pritožbe, nalaganje obveznosti, vprašanja, ukazi, ipd.

Neverbalne taktike so: ton glasu, govorica telesa, oblačenje, kretnje, retorični presledki, ipd.

Situacijska taktika pa so npr. postavljanje časovnih rokov, zahteve po premorih, ipd.

Poleg naštetega gre še za mnogo več. K pogajalskim taktikam prištevamo:

- vplivanje na dinamiko pogajanj;

- tekmovalnost oziroma ponudbe sodelovanja;

- postavljanje pogojev oziroma velikodušnost;

- zavestno izražanje (igranje) čustev (npr. jeze, zaskrbljenosti);

- zavrnitve oziroma ponudbe izmenjave nečesa, kar za drugo stran predstavlja vrednost;

- odzivanje oziroma molk;

- predočanje oziroma zanikanje dejstev;

- demonstracije moči oziroma popuščanje;

- sklicevanja;

- drugo.

Pomen poznavanja pogajalskih taktik je dvojen. Na eni strani je izbira taktik del vsebine priprav na pogajanja. Pomeni, da si vnaprej poskušamo odgovoriti na vprašanje, na kakšen način bomo dosegli postavljene cilje.

Na drugi strani pa je poznavanje pogajalskih taktik pomembno, da razumemo ravnanje nasprotne strani in da razpolagamo z znanjem, kako se odzivati ob zaznavah uporabljenih taktik nasprotne strani.

Obstajo številni učbeniki pogajalskih taktik. V vsakih pogajanjih se pojavljajo elementi že znanih taktik. Tudi, če so pristopi inovativni, se v njih pogosto pojavljajo elementi že poznanega.

Splošno veljavnega pravila glede izvedbe pogajanj in uporabe pogajalskih taktik ni. Vsaka pogajanja namreč potekajo $\mathrm{v}$ različnih okoliščinah, o različnih vsebinah in $\mathrm{v}$ 
različnih časovnih obdobjih. Kar je včeraj veljalo za uspešno pogalsko taktiko, je v današnjih drugačnih okoliščinah lahko popolnoma zgrešeno.

Pogajalske taktike torej niso nekaj, kar nam bo samo po sebi zagotovilo dosego zastavljenih ciljev pogajanj. Prav tako jih moramo obravnavati čim bolj fleksibilno. Na to kažejo številni rezultati raziskav in primeri iz zgodovine. Navajamo zgolj nekatere.

Po koncu II. svetovne vojne je vse do leta 1973 ostalo nerešeno vprašanje meje med Republiko Italijo in SFR Jugoslavijo. Mejo med državama so desetletja neuspešno skušali urediti na mednarodnih konferencah in z diplomatskimi pogajanji. To so bili načini, ki veljajo za običajne. Na srečanju zunanjih ministrov obeh držav Miloša Minića in Giuseppeja Medicija marca 1973 v Dubrovniku pa je bilo dogovorjeno, da bodo to vprašanje skušali rešiti na inovativen način. Dogovorili so se za vzporedna pogajanja po »drugem kanalu«. Imenovana sta bila odposlanca obeh držav: Boris Šnuderl in Eugenio Carbone. Oba sta prejela ustrezna pooblastila. Pogajanja med njima so potekala v popolni tajnosti. Rezultat pogajanj po »drugem kanalu« je bil Osimski sporazum med Republiko Italijo in takratno SFR Jugoslavijo. S sporazumom je bila določena meja med državama, uredili pa so tudi številne druge zadeve. Podpisan je bil 10. novembra 1975 blizu kraja Osimo v Italiji.

Drugače je bilo z določitvijo meje med Republiko Slovenijo in Republiko Hrvaško. Vprašanje meje se je pojavilo po razpadu SFR Jugoslavije. Državi sta več let poskušali določiti mejo. Na koncu sta se v pogajanja vključila tudi predsednika vlad obeh držav Ivica Račan in Janez Drnovšek. 20. julija 2001 sta celo parafirala Pogodbo o skupni državni meji. Vendar kljub vključitvi predsednikov vlad obeh držav in kljub njunima parafoma ta pogodba na koncu ni obveljala.

Podobno velja za številna politična pogajanja v različnih delih sveta. Vsi poznamo obstoj številnih odporniški skupin, ki so se borile proti okupatorjem, ter uporniške in teroristične skupine, ki se borijo proti vladam v svojih državah. Manj znano pa je, da so se v različnih obdobjih vlade različnih držav z njimi tudi pogajale.

Heger in Jung (2015) sta opravili analizo 400 uporniških skupin v različnih delih sveta in $\mathrm{v}$ različnih časovnih obdobjih. Analizirali sta tudi pogajanja s skupinami kot sta IRA in Hamas, ter s skupinami v državljanski vojni v Siriji. Rezultati analize so pokazali, da taka pogajanja nedvomno obstajajo. $\mathrm{Na}$ obstoj, dinamiko in uspešnost pogajanj so vplivali številni dejavniki. Najpomembnejši dejavnik, ki vpliva na pogajanja je »zagotavljanje storitev uporniške skupine« članom in prebivalstvu (npr.: zdravstva, oskrbe s hrano, vodo, ipd.). Naslednji pomembni dejavniki so še:

- obstoj tretje osebe, ki bo jamčila za uresničitev dogovorjenega;

- stopnja identifikacije članov skupine $\mathrm{z}$ ideologijo in $\mathrm{s}$ tem povezana agresivnost;

- stopnja notranje enotnosti vladne starni in na drugi strani enotnost uporniške skupine;

- stopnja legitimnosti zahtev. 
Ključna ugotovitev je ta, da nikoli in nikjer ne obstaja nobena ovira, da se pogajanja ne bi mogla začeti in da so vsaka pogajanja unikatna.

Med II. svetovno vojno so se pogajali celo Nemci in partizani in to celo v času najhujšihh spopadov bitke na Neretvi. Obstoj pogajanj v marcu in aprilu 1943 dokazujejo arhivski dokumenti. Člani delegacije partizanov so bili: Koča Popović, Milovan Đilas in Vladimir Velebit. Zanimivo je, da pooblastila pogajalcem partizanske strani ni podpisal Josip Broz Tito kot vrhovni komandant, pač pa ga je podpisal namestnik načelnika vrhovnega štaba Mihajlo Terzić. Zanimivo je tudi to, da je Adolf Htiler tem pogajanjem nasprotoval. Kljub temu dokazi kažejo, da so pogajanja nedvomno bila. Do njih je lahko prišlo iz več razlogov. Rezultat pogajanj kaže, da je za pogajanja najbrž obstajal osebni interes posameznikov. Obstajala naj bi tudi »relacijska zgodovina« nekaterih posameznikov. Oče Vladimira Velebita Ljubomir Velebit je bil visok častnik v vojski Avstro-ogrske monarhije in kasneje general. Predstavnik nemške vojske v Zagrebu general Edmund Glais von Horstenau pa naj bi bil njegov znanec. Tako pri Nemcih kot pri partizanih je obstajal tudi interes za uničenje četnikov. Vendar je ob tem treba jasno izpostaviti skepso, da so se pogovarjali tudi o uničenju četnikov, saj imajo zgodovinarji o tem zelo različna mnenja, dokumenti o tem pa ne obstajajo oziroma niso dostopni. Rezulat pogajanj je nedvomno bil izmenjava manjšega števila vojnih ujetnikov oziroma zapornikov. Zanimivo je, da so po teh pogajanjih iz zapora v Zagrebu ustaši izpustili takratno Titovo ženo Herto Hass, partizani pa so izpustili nekatere nemške vojne ujetnike. 
Poslovno KomUniciRANJE

Pogajanja 


\section{MEDKULTURNA POGAJANJA}

Pogajanja so medkulturna, če pogajalci:

- prihajajo iz različnih kulturnih okolij;

- prakticirajo prakse različnih kulturnih okolij;

- izražajo za okolje značilen način čustvenega odzivanja na zaznave;

- ne delijo enakih vrednot.

Eno najbolj celovitih študij o kulturah je opravil Geert Hofstede. Hofstede (2001) pravi, da je kultura kolektivno programiranje uma, ki razlikuje člane ene skupine ali kategorije ljudi od drugih. Pravi, da ima kultura družbe šest dimenzij:

Odnos do moči izraža stopnjo, do katere šibkejši člani družbe sprejemajo, da je moč v družbi porazdeljena neenako.

Individualizem oziroma kolektivizem se odraža v opredelitvi človekove samopodobe v smislu "jaz" ali "mi«. Individualizem je družbeni okvir, v katerem je splošno sprejeto in se pričakuje, da bodo posamezniki poskrbeli samo zase. Nasprotje je kolektivizem, v katerem je splošno sprejeto in se pričakuje, da bodo člani skupine $\mathrm{v}$ zameno za nesporno zvestobo poskrbeli za posameznike.

Moškost oziroma ženskost družbe predstavlja kriterij za vrednotenje dosežkov. Moškost v družbi pomeni, da se cenijo dosežki, herojstvo in materialne nagrade za uspehe. Nasprotje je ženskost, kjer se ceni sodelovanje, skromnost, in kakovost življenja.

Izogibanje negotovosti izraža stopnjo zaznavanja neugodja v nepredvidljivih, neznanih, ali novih okoliščinah. Kulture se med seboj razlikujejo tudi v odnosu do neobičajnega vedenja in do novih idej.

Odnos do prihodnosti predstavlja razmerje med težnjami po ohranjaju tradicije in spremembami.

Tolerantnost oziroma zadržanost pomeni odnos do užitkov. Tolerantna je družba, ki ljudem poleg zadovoljevanja osnovnih življenjskih potreb dopušča tudi užitke in zabavo. V nasprotju družba lahko s strogimi normami užitke in zabavo tudi zavira.

Atributi kulture družbe po metodologiji GLOBE temeljijo na ugotovitvah Hofstede-ja. So pa nekoliko širši in vsebujejo atribute: izogibanje negotovosti, odnos do moči, družbeni kolektivizem, skupinski kolektivizem, enakopravnost spolov, samozavest, usmerjenost $\mathrm{v}$ prihodnost in usmerjenost $\mathrm{v}$ uspešnost. 
V medkulturnih pogajanjih se poleg navedenih razlik postavljajo dodatna vprašanja:

- Kakšna je dejanska moč pogajalskega parnerja v družbi?

- Kakšna je stopnja zaupanja med kulturami?

- Kakšen je odnos do časa?

- Kakšna je stopnja zavezanosti izpolnitvi dogovora?

- Kakšna so zagotovila za izpolnitev dogovorjenega?

- Ali identična sporočila enako interpretiramo?

Pri mnogočem od naštetega med kulturami obstajajo pomembne razlike. 


\section{LAŽNA POGAJANJA}

Običajni namen pogajanj je preučiti možnosti in če je le mogoče doseči tudi dogovor. Obstajajo pa tudi izjeme. Organizacija ima za cilj pogajanj lahko zgolj ohranitev »statusa quo«. Status quo je stanje, ko se nič ne spremeni. V takem primeru je že vsebino priprav na pogajanja treba podrediti temu cilju.

Lažna pogajanja so pogajanja, kjer se ena stran pogaja brez kakršne koli namere, da bi dosegla dogovor. Lažna pogajanja se pojavijo, kadar ima ena stran take zadržke, da ne more pristati na dogovor. Zato čaka, da pride v okolju do spremembe, ki ji znatno izboljša položaj. Glozman in soavtorji (2014) za tako ravnanje navajajo naslednje razloge:

- zadržki, ki onemogočajo sklenitev dogovora;

- namen pogajanj je zgolj zbiranje obveščevalnih podatkov o konkurentu;

- pogajanja se začnejo zgolj zato, da bi organizacija ohranila ali celo izboljšala svoj ugled;

- pogajanja se začnejo zgolj zato, da bi pomirili dejavnike okolja in preprečili morebitne sankcije.

Lažni pogajalci se v trenutnem okviru pogajanj na vsak način skušajo izogniti sporazumu, prizadevajo pa si ohraniti pogajalski proces. Zavrnitev ali prekinitev pogajanj bi namreč lahko ogrozila njihov položaj. Lažni pogajalci uporabljajo taktike, ki »obremenijo« pogajanja. Vendar so njihove namere prikrite. Ves čas pogajanj ohranjajo videz sodelovanja.

Tipični simptomi lažnih pogajanj so:

- sklicevanje na omejenost pooblastil oziroma nepooblaščeni pogajalci;

- odlaganje odgovorov na pobude;

- zahteve po premorih med pogovori;

- uporaba tekmovalnih pogajalskih taktik;

- pogovori o abstraktnih zadevah in izogibanje konkretnim temam;

- molk oziroma zgolj poslušanje.

Na lažna poganja lahko posumimo, če se simptomi kopičijo. Zgolj na podlagi pojava enega simptoma ni mogoče soditi, da so poganja lažna. 
Poslovno KomUniciRANJE

Pogajanja 


\section{ZAKLJUČEK POGAJANJ}

Dogovor ob zaključku pogajanj pomeni uspeh. Pogajanja pa se lahko končajo tudi brez dogovora.

Med pogajanji se navadno skuša vzpostaviti povezava med stališči obeh pogajalskih strani. Obstajajo obdobja, ko se daje koncesije in obdobja, ko se stališča zaostrujejo.

Tako proces približevanja, kot tudi proces popuščanja lahko pripeljeta do »mrtve točke«. Mrtva točka je stanje pogajanj, ko se zdi, da sporazum ni mogoč.

Pogosto pa se nenadoma zgodi nekaj od naslednjega:

- sprememba dnevnega reda in pogajanja o manj zapletenih zadevah;

- odmor;

- začetek vzporednih neformalnih pogajanj;

- zamenjava pogajalcev;

- propagandne poteze;

- zunanja arbitraža.

V neki fazi pogajanj pa po določenem času pogosto pride do signalov, ki pogajalcem povedo, da so proces pogajanj pripeljali do točke, ki je zrela za zaključek. Najbolj tipični signali so:

- ritem pogajanj se umiri ali pospeši;

- pogajalci kar na lepem začno spraševati;

- pogajalci ene strani dajo pozitivno spodbudo z vsebinskimi vprašanji.

Obstajajo številne raziskave o tem, na kakšen način pogajalci ob zaključku pogajanj sprejemajo odločitve. Teorija pozna različne modele zaključevanja pogajanj. Vendar gre zgolj za teoretične modele. Omenili smo, da so vsaka pogajanja unikat in jih med seboj ni mogoče primerjati.

Raziskava, katero je leta 2014 opravila Melania-Gabriela Ciot pomeni nov pristop k raziskovanju sprejemanja odločitev. Ciot (2014) je ugotovila, da se skozi stoletja na mednarodnem prizorišču pojavljajo impresivna zaporedja dogodkov. Zato jo je zanimalo, kdo so akterji teh dogodkov, kako se akterji odzivajo na posamezne situacije in kdo ter kako sprejema makro in mikro odločitve v mednarodni politiki.

Ciot (2014) pravi, da na odločitve pogajalcev na koncu vplivajo dejavniki, kot so: osebnost pogajalcev, prepričanja vodij, stil vodenja, čustva, individualne in kolektivne kognicije, uporaba analogij in inteligentnost. Način sprejemanja končnih odločitev se 
Pogajanja: Zaključek pogajanj

navzven pogosto zdi popopolnoma neracionalen. Vendar pa to ne pomeni, da nosilci odločanja res ravnajo neracionalno. 


\section{LOBIRANJE}





\section{KAJ JE LOBIRANJE}

Lobiranje je prepričevanje ljudi, ki o nečem odločajo, z namenom vplivanja na njihove odločitve.

Kot pravi Zetter (2008) naj bi lobiranje imelo zelo dolgo zgodovino. Lobiralo naj bi se v antični Grčiji in v starem Rimu. V starem Rimu naj bi lobisti obiskovali člane senata in poskušali vplivati na njihove odločitve. Na kraljevih dvorih srednjega veka se je trlo dvorjanov, ki so bili lobisti tistega časa.

Zetter (2008) navaja, da izvor izraza »lobist« izhaja iz leta 1860. Takratni predsednik ZDA Ulysses S. Grant naj bi se naveličal ljudi, ki so si želeli trenutka njegove pozornosti in vplivati nanj. Zaničljivo naj bi jih imenoval »lobisti«. Schendelen (2013) pa pravi, da beseda izvira iz srednjega veka. Beseda »lobia« naj bi v srednjeveški Italiji pomenila »pot k princu«.

V 19. stoletju je bilo v ZDA lobiranja že tako veliko, da je postalo prava »industrija«. Zato je leta 1928 Senat sprejel sklep, da se lobisti morajo vpisati v register. Področje integritete, preprečevanja korupcije in delo lobistov nasploh danes tudi v Sloveniji ureja zakonodaja Tudi Evropska komisija je marca 2007 odločila, da ustanovi javni register vseh zastopnikov interesov v institucijah Evropske skupnosti.

Pojem lobi pomeni "neformalno skupino ljudi, ki si prizadeva uveljaviti svoje (politične) interese «. ${ }^{34}$ Skupina ljudi navadno pooblasti predstavnika, ki neposredno zastopa njene interese v interakciji s tistimi, ki o nečem odločajo. Predstavnik skupine se imenuje lobist. Lobist je lahko član skupine, lahko pa tudi plačan agent, ki ni član neformalne skupine.

Bouwen (2009) pravi, da ima lobiranje v organih Evropske skupnosti naslednje funkcije:

- vplivanje na zakonodajo;

- vplivanje na izvršilno vejo oblasti;

- funkcijo varovanja interesov posameznih interesnih skupin.

Mnogi menijo, da je lobiranje element demokracije. Seveda se drugi s tem morda lahko ne strinjajo. Richardson in Coen (2009) navajata oceno, da je bilo leta 2009 v Evropskem parlamentu 5.039 akreditiranih interesnih skupin, od tega 70 odstotkov predstavnikov podjetij in gospodarskih interesnih združenj in 30 odstotkov predstavnikov nevladnih organizacij.

Motive organizacij za lobiranje je treba pojasniti v kontekstu opredelitve namena obstoja organizacije. Kot smo že večkrat navedli, neoliberalizem opredeljuje namen

\footnotetext{
${ }^{34}$ Slovar slovenskega knjižnega jezika.
} 
obstoja podjetij kot dobiček. Tako pojmovanje je seveda legitimno. Toda v zadnjih desetletjih se je izkazalo, da je vedno bolj pomembno:

- zadovoljstvo potrošnikov;

- družbeno-odgovorno ravnanje organizacij.

Že po naravnih zakonitostih je količina vseh dobrin v naravi omejena. To velja tako za naravne danosti, kot za ekonomske dobrine. Organizacije ne morejo doseči neomejeno visokega dobička za lastnike, hkrati pa zadovoljiti morda nerealnih pričakovanj potrošnikov in povrhu vsega še ravnati skladno z vsemi najvišjimi načeli družbene odgovornosti.

Tudi na zakonodajni ravni je torej treba najti neko sprejemljivo družbeno ravnovesje med različnimi interesi. Procesi, povezani z sprejemanjem pravnih norm, torej niso in ne morejo biti enosmerni procesi.

Lobiranje je torej treba gledati tudi kot proces usklajevanja interesov glede razporeditve in porabe naravnih in ekonomskih danosti ter porazdelitve družbene odgovornosti.

Ob lobiranju se vedno lahko postavljajo vprašanja glede:

- legitimnosti interesov;

- skladnosti stališč zakonodajalcev in lobistov z družbeno realnostjo;

- etičnosti uporabljenih metod lobiranja;

- meja med lobiranjem in korupcijo.

Po klasičnem pojmovanju lobiranja gre za vplivanje organizacij na odločitve državnih organov (ministrstev, vlade oziroma parlamenta) ter lokalnih organov oblasti (npr.: občinskih svetov). Glavna karakteristika lobija je torej, da poskuša vplivati na oblikovanje politike - da od državnih organov želi neko določeno aktivnost ali neaktivnost. Pomembno je, da politika lobiste in lobiranje sprejema. Lobiranje se je pogosto enačilo s korupcijo. Med pravim lobiranjem in podkupovanjem je seveda zelo velika razlika.

Pri proučevanju lobiranja pogosto naletimo na vprašanje, kdo je $\mathbf{v}$ praksi podvržen lobiranju. Gre za temeljno dilemo o:

- lobiranju pri politikih, kot atributih zakonodajne oblasti;

- lobiranju pri upravi kot izvršni oblasti;

- lobiranju pri administrativnem osebju v politiki in upravi.

Popolna ločitev državne uprave od politike je navadno zgolj ideal. Politika naj ne bi imela neposrednega vpliva na državno upravo, ima pa mnogo možnosti za posredno vplivanje. Zato v praksi lahko govorimo o lobiranju tako na politiko, kot na upravne organe države. 
Ne smemo pa zanemariti vpliva lobiranja na administracijo. Prav administracija je zelo pogosto tista, ki pripravlja podlage za odločanje in nemalokrat tudi predloge rešitev za odločevalce.

Lobira se:

- na ravni države;

- na ravni lokalnih skupnosti;

- na ravni evropske skupnosti.

Od srednjega veka se je lobiranje precej spremenilo. Še zlasti so se stvari spremenile po širitvi Evropske unije:

- Število interesnih skupin se je neprestano povečevalo.

- Akumulacija znanja v interesnih skupinah je postajala vedno večja.

- Prišlo je do decentralizacije oblasti in $\mathrm{s}$ tem do redistribucije moči.

- Število tistih, ki odločajo o javnih zadevah se je povečalo.

- Stopnja profesionalizacije državne in lokalne uprave je vedno večja.

- Prišlo je do sprememb v kulturi družbe.

V času srednjega veka je bilo za dosego cilja morda celo nujno potrebno posredovanje vplivne osebe pri vladarju. Seveda si nikakor ne moremo delati iluzij, da tak način lobiranja še danes tudi pri nas ni možen-včasih celo potreben. Vendar danes za dosego nekega cilja mnogokrat sploh ni nujno posredovanje vplivne osebe. Ob uporabi pravega znanja in osebnih talentov se stvari enostavno »zgodijo «. Nekateri niti besede »lobiranje« ne uporabljajo več, pač pa uporabljajo izraz »public affairs management« $(P A M)$.

Schendelen (2013) pravi, da se danes pri lobiranju mora uporabljati ogromno znanja, spremenile so se metode in taktike lobiranja, lobisti pa morajo biti izjemno talentirani. Viri znanja o lobiranju so:

- politične vede;

- vede o komuniciranju;

- vede o managementu;

- dobre prakse.

Proces lobiranja sestoji iz več faz. Faze so:

- odločanje o lobiranju;

- izbor lobista;

- analiza stanja;

- določanje dinamike lobiranja;

- izbor metod in taktik lobiranja;

- udejanjanje;

- vrednotenje učinkov lobiranja. 
PosLOVNO KOMUNICIRANJE

Lobiranje 


\section{ODLOČITEV O LOBIRANJU}

Lobira se zato, da bi prišli do rešitve, ki je moralna, etična, skratka, ki predstavlja "resnico«. Lobiramo pa tudi zato, da bi zadovoljili svoj interes. Organizacije navadno lobirajo zato, da bi dosegle interes, ki je neposredno povezan $\mathrm{z}$ opredelitvijo obstoja organizacije.

Lahko pa obstaja zgolj simbolni ali prestižni razlog za lobiranje. Lahko gre zgolj za demonstracijo moči. Moč je sposobnost uveljavljanja svoje volje tretjim osebam. Poznamo pa še:

- lobiranje za dosego konkretnih ciljev v zvezi s poslovanjem z državo (npr.: nakup, prodaja, koncesije, finančni posli, ...);

- lobiranje za dosego osebnih ciljev.

Preden se neka organizacija odloči za lobiranje, mora odločitev dobro pretehtati:

- kakšne posledice bodo za organizacijo (ali posameznika) nastale ob taki ali drugačni odločitvi zakonodajnega organa;

- kaj se bo zgodilo v primeru, če na odločitev ne bomo vplivali;

- katere so alternativne rešitve.

Schendelen (2013) kot abstrakten primer odločanja držav o lobiranju pri sprejemanju odločitev v Evropski skupnosti navaja primer sprejemanja standardov za cevi plinovodov. Cevi za plinovode proizvajajo v več državah: V združenem kraljestvu, Italiji, Nemčiji in na švedskem. Vsi trdijo, da imajo najboljše in vsak si želi povečati tržni delež. Vpletejo se še potrošniške organizacije, ki zahtevajo poceni plin. Okoljevarstveniki postavljajo svoje zahteve. Zadeva se začne politizirati. Teoretično gledano so alternativne rešitve nastale situacije lahko:

- Izstop iz Evropske unije: Stroški izstopa so lahko nižji, kot katerakoli druga rešitev.

- Toleranca: Neka država lahko pri reševanju kakega vprašanja tolerira druge, vendar v tem primeru pričakuje koncesijo na nekem drugem področju.

- Vojna: V Evropi je vojna že večkrat bila.

- Imitacija: Vlade in podjetja se lahko odločijo slediti najboljšim praksam in prilagodijo svoje prakse tako, da odpravijo medsebojne razlike.

- Pogajanja: Vlada ali podjetje lahko začne pogajanja z odgovornimi za razlike.

Če se samo malo ozremo v zgodovino Evrope, zlahka ugotovimo, da te rešitve niso niti abstraktne, niti teoretične, pač pa so bile v zgodovini povsem realne. Vsaka od rešitev se je v zgodovini Evrope že zgodila, zato nobene od njih nikoli ni mogoče popolnoma izključiti. 
Preden se neka organizacija ali posameznik odloči za lobiranje, mora vnaprej vedeti, da ob še tako skrbnem načrtovanju in planiranju ter tudi ob brezhibni izvedbi lobiranje ni nujno tudi uspešno. Zato je treba vnaprej predvideti možne omejitve lobiranja. Schendelen (2005) našteva naslednje omejitve:

Omejitve kompetenc in notranjega konsenza organizacije: $\mathrm{Ni}$ nujno, da vsaka organizacija razpolaga s kadri in znanjem za uspešno lobiranje. Tudi, če organizacija angažira zunanje lobiste, mora razpolagati $\mathrm{z}$ vsaj minimalnim lastnim znanjem o strukturi odločanja, o načinu funkcioniranja odločevalcev, ipd.

Duševne omejitve osebe, ki lobira (lobista) so:

- čustva;

- dogme in

- miti.

Prav čustva so tista, ki ločujejo zmagovalce od poražencev. Seznam čustev pa je neskončen.

Dogme so močna vnaprejšnja prepričanja o nečem. Dogme onemogočajo konstruktivno razpravo.

Miti so podobe realnosti. $\mathrm{V}$ resnici so fikcije in nimajo nobene podlage $\mathrm{v}$ realnosti. Izhajajo iz tradicije, propagande, tabloidov, socialnih kognicij in shem, ali celo iz lastne nesposobnosti posameznikov, ki se deklarirajo kot mnenjski voditelji. Tipični miti nesposobnih mnenjskih voditeljev so:

- $\quad \gg$ Jaz sem za. Ampak zakaj ravno zdaj?«

- $\quad$ To se ne da.«

- „Saj veš, da sem jaz vedno konstruktiven.«

\section{Organizacijske omejitve so:}

- pomanjkanje notranje kohezivnosti;

- občutek ogroženosti in

- slabo vodenje.

Pomanjkanje notranje kohezivnosti pomeni, da znotraj organizacije glede rešitve, za katero se lobira, ne obstaja konsenz. Kot smo omenili v enem od predhodnih poglavij, ima organizacija lahko več identitet. V najslabšem primeru se zgodi, da kakšna neformalna skupina znotraj organizacije aktivno lobira za drugačno rešitev, kot jo zagovarja vodstvo. Taka ravnanja so nepopravljiva in imajo dolgoročne posledice $\mathrm{v}$ izvrševanju namena obstoja organizacije. 
Občutek ogroženosti je lahko prednost ali slabost. Lahko povzroči še bolj skrbne priprave na lobiranje, kot sicer. Po drugi strani pa lahko povzroči paniko, strah, nagle in posledično povsem napačne odločitve.

Slabo vodenje ima lahko številne pojavne oblike. Najbolj se odraža v napačni oceni dejanskih kompetenc organizacije, v čustvenih in neracionalnih odzivih in v amaterskem pristopu k lobiranju.

Omejitve kanala, prek katerega se lobira imajo več razsežnosti. Kot bomo opisali v nadaljevanju, obstajajo številne metode lobiranja. V praksi:

- po eni strani ni nujno, da organizacija sploh ima resurse za izvedbo vseh možnih metod lobiranja;

- po drugi strani pa zaradi vsebine lobiranja uporaba vseh metod lobiranja za konkretni primer ni možna, tudi če organizacija razpolaga $\mathrm{z}$ resursi.

Omejitve »arene« v kateri se lobira so:

- pluralizem;

- kompleksnost in

- dinamika.

Pluralizem pomeni različnost mišljenj o isti zadevi. Glede iste zadeve morda lobirajo različne interesne skupine, seveda za različne rešitve.

Kompleksnost pomeni, da se posamezne rešitve lahko nanašajo na različne javnosti in na različne interesne skupine. Vsaka od interesnih skupin je v drugačnem položaju. Zato so pomembne tudi interakcije med različnimi interesnimi skupinami.

Dinamika pomeni, da se skozi čas spreminjajo informacije o ključnih dejstvih, prioritete in tudi vrednote.

\section{Omejitve osebe, pri kateri se lobira so:}

- nepozornost;

- zasičenost in nevtralizacija.

Nepozornost je lahko posledica dogem, mitov, utrujenosti, ipd. povzroči, da prejemnik sporočila ne percepira na način, kot si ga želi lobist. 
Lobiranje: Odločitev o lobiranju

Nevtralizacija je pojav, da se s številom sporočil o isti zadevi (z zasičenostjo) manjša vpliv vsakega od sporočil. To še posebej velja, če so si vsebine sporočil nasprotujoče. V praksi ima oseba, ki je podvržena lobiranju, možnost, da na koncu:

- naredi tisto, kar od njega pričakuje lobist;

- ravna nasprotno, kar pričakuje lobist;

- naredi nekaj tretjega;

- ne stori ničesar. 


\section{IZBOR LOBISTA}

Odločiti se je treba, ali za lobiranje angažirati notranjega člana, ali najeti zunanjega lobista. Obe možnosti imata vsaka svoje prednosti in slabosti. Prednosti angažiranja zunanjega lobista so:

- zunanji lobist je specialist in ima potrebna znanja in veščine;

- navezane ima svoje osebne kontakte;

- lahko je emocionalno povsem neodvisen od problema;

- uživa večje zaupanje in večji ugled med tistimi, ki odločajo;

- navadno si ne sme privoščiti zavajanja;

- izpade »profesionalno«;

- drugo.

Prednost notranjega lobista pa je, da bolje pozna problemsko stanje.

Lobist je poklic. V nekaterih državah je registriranih tudi več sto lobistov. Lobist je tisti, kdor od zunaj skuša vplivati na odločitve. Dela za znanega naročnika. Torej je posrednik med naročnikom in ljudmi v državnem aparatu (strokovni organi izvršilne oblasti države, zakonodajna telesa), ki o nečem odločajo. Ljudje, ki o nečem odločajo namreč ne morejo biti strokovnjaki vseh strokovnih področij, s katerih sprejemajo odločitve. O zadevah se morajo podučiti. V ta namen se poslužujejo različnih virov informacij. To jim vzame zelo veliko časa. Osnovna metoda dela lobista je torej informiranje in prepričevanje ljudi, ki sprejemajo odločitve. Naloga lobista je, da naveže kontakte z ljudmi, ki odločajo (npr.: s poslancem $\mathrm{v}$ parlamentu) in jim posredujejo dejstva in argumente. Za politika podvrženost lobiranju pomeni priložnost, da se seznani z mnenjem volivcev oziroma interesne skupine volivcev. Lobist politiku lahko predstavi argumente, do katerih bi se politik sam dokopal šele po dolgotrajnem raziskovanju.

Poznamo več tipov lobistov:

- Tradicionalni lobisti so vplivni bivši (ali še aktivni) člani večjih političnih strank. Ti lobisti lobirajo predvsem pri političnih strankah. Pripadnost stranki jih pogosto omejuje pri njihovem delu.

- Bivši državni uslužbenci se pri lobiranju poslužujejo poznanstev v administraciji in politiki. Politika jih manj omejuje, zato so lahko bolj učinkoviti.

- Svetovalci političnih strank delujejo podobno kot tradicionalni lobisti.

Agencij za odnose z javnostmi se poslužujemo pri indirektnih metodah lobiranja. 
Lobiranje 


\section{ANALIZA STANJA}

Preden se začne kakršnakoli akcija lobiranja, je potrebna temeljita analiza stanja. Ta mora pokazati realne možnosti za uspeh lobiranja. V analizi sodelujejo strokovnjaki različnih področij, pogosto tudi zunanji lobisti. Če je verjetnost za uspeh lobiranja majhna, mora lobist naročniku to jasno povedati.

Med procesom analize je treba ugotoviti:

- kdo so tisti, ki o nečem odločajo;

- kakšna so njihova predhodna stališča;

- kaj je motiv za taka stališča (npr.: ideologija, možnost kariere, ...);

- kateri dejavniki vplivajo na njihove odločitve.

Pri oblikovanju skupine, kateri bomo lobirali, gre za oblikovanje dveh glavnih skupin:

- Primarno skupino sestavljajo ljudje, za katere se ocenjuje, da bodo imeli odločujoč vpliv pri odločanju.

- Sekundarno skupino sestavljajo ljudje, za katere se ocenjuje, da bodo potencialno lahko vplivali na odločitve.

Primarna skupina je praviloma zelo ozka. Niti ni nujno, da so to vsi člani vlade oziroma parlamenta. Tudi znotraj primarne skupine poznamo različne stopnje vpliva na odločitev. Posameznik v primarni skupini ima lahko celo prevladujoč vpliv.

Nasprotno pa je sekundarna skupina zelo široka. Sestavljajo jo: vsi člani parlamenta in državnega sveta, zastopniki lokalnih interesov, direktorji najpomembnejših podjetij, uredniki največjih medijev, novinarji specializiranih rubrik in celo tuji diplomati.

Ob podeljevanju ene od koncesij v Sloveniji je kandidat za pridobitev koncesije razvrstil odločevalce v tri kroge:

- Širši krog so ljudje, ki jih problematika zanima.

- Ožji krog so ljudje iz širšega kroga, ki imajo vpliv na odločevalce.

- Najožji krog so tisti, ki dejansko odločijo.

V širšem krogu je bilo od 800 do 1000 oseb. V najožjem krogu odločevalcev naj bi bilo zgolj do 10 oseb.

Ko smo ugotovili, kdo bo o nečem odločal, moramo ugotoviti, kateri so elementi, ki bodo pri odločitvi posameznika ključni. Posamezniki sprejemajo odločitve na podlagi:

- pripadnosti politični stranki oziroma vodji stranke; 
- tako imenovanega "nacionalnega interesa";

- osebnih interesov, kot je npr.: možnost lastne kariere;

- pritiska javnega mnenja;

- poslovnih interesov oziroma ekonomskih kriterijev;

- načela resnice oziroma pravice;

- racionalnih argumentov za določeno opcijo;

- emocionalnih dejavnikov (npr.: ideologije);

- drugega.

Vsako lobiranje je potrebno prilagoditi vsakokratni javnosti posebej. Oceniti je treba:

- kakšno je predhodno stališče posameznika, pri katerem lobiramo (pomembni so morebitni stereotipi);

- ali posameznik morebiti pripada javnosti, ki nasprotuje našemu stališču;

- kakšen je njegov osebni interes;

- kakšen je njegov vpliv na odločitev (majhen, srednji, izrazit, odločujoč);

- kakšna je njegova predhodna stopnja informiranosti o problemu;

- drugo.

Schendelen (2013) pravi, da se za metodo in taktiko lobiranja odločimo na podlagi več dejavnikov.

Stališče odločevalca: Stališču organizacije je lahko naklonjeno ali pa tudi ne.

Odnos do deležnikov: Dilema je, ali nagraditi prijatelje in tiste, ki se predajo, ali kaznovati nasprotnike in prebežnike.

Relacije: Gre za vprašanje, ali uporabiti formalne kontakte, pol-formalne ali povsem neformalne. Drugo vprašanje pa je: ali uporabiti že obstoječe osebe in kanale komuniciranja ali vzpostaviti povsem nove.

Procedure sprejemanja odločitev: Lahko so zelo enostavne ali pa zelo kompleksne. Temu primerno je treba prilagoditi dinamiko in metode lobiranja.

Pozicije: Pomembno je vedeti, na kakšen način je konkretna oseba zasedla položaj odločevalca.

Vrednote: gre za vprašanja:

- Ali je iz vidika vrednot, ideologij oziroma delovanja političnih strank pomembna ali ne?

- Ali je neka zadeva »politična« ali »tehnična«?

- Ali zadevo »politizirati« ali »nepolitizirati«?

- Ali jo obravnavati »posamezno« ali »v paketu« z drugimi zadevami? 
Okviri imajo več razsežnosti:

- Interes je lahko parcialen, torej sebičen interes organizacije, ali pa je širši družbeni interes.

- Interes lahko predstavlja popolno novost, ali pa zahteva zgolj prilagoditev že obstoječih rešitev.

- Interes jelahko nesporen za vse, ali pa vsebuje eno ali več dimenzij, ki je iz vidika že obstoječih rešitev ali vrednot sporna. 
PosLOVNO KOMUNICIRANJE

Lobiranje 


\section{DOLOČANJE DINAMIKE LOBIRANJA}

Pravilno izbran čas lobiranja je ključen za uspeh. Če zamudimo najugodnejši trenutek, se lahko zgodi, da smo izgubili celo leta. Morda so posledice celo nepopravljive. Lobiranje je najbolj učinkovito:

- $\quad \mathrm{v}$ času pred volitvami;

- preden neka zadeva postane javna;

- $\quad$ c času, ko je neka zadeva na vrhuncu publicitete;

- preden gre neka zadeva v obravnavo v parlament;

- ko je zadeva v parlamentarni proceduri.

Zelo primeren čas za lobiranje je čas pred volitvami. V mesecih pred volitvami politiki zbirajo podporo in so dostopni bolj kot sicer. Radi prisluhnejo čemerkoli, za kar mislijo, da jim bo prineslo nekaj volilnih glasov. To velja izkoristiti za predstavitev svojih stališč in problemov. Nikakor ni pametno pretirano javno favorizirati samo enega kandidata na račun drugega. Še zlasti, če smo preveč podvrženi ideologiji, so rezultati volitev za nas lahko polni presenečenj in razočaranj. Zlasti neprimerno je, da o drugih kandidatih v javnosti slabo govorimo. Pogosto je, da se organizacije poslužujejo lobiranja pri več kandidatih hkrati; podpirajo lahko več kandidatov različnih političnih strank. Če pa je naše "ideja" oziroma zadeva v javnosti predhodno predstavljena kot nekaj, kar bi utegnilo imeti negativen predznak oziroma bi utegnila kandidatom celo škoditi na volitvah, je bolje, da z lobiranjem počakamo na čas po volitvah.

Pogosto se zgodi, da je nek problem pereč, vendar še ni predstavljen v javnosti, ker mediji zanj še niso izvedeli. Dobro je, da lobiramo, preden zadeva postane javna, skratka da smo prvi. To omogoča, da večji poudarek pri predstavitvi zadeve posvetimo vidikom, ki so za nas najbolj pomembni.

Ko neka zadeva postane javna, ji mediji namenijo več ali manj prostora. Za vsako zadevo oziroma novico velja, da ima svoj življenjski ciklus. V nekem trenutku se pojavi v medijih. Nato pozornost medijev narašča in v nekem trenutku pride do viška pozornosti. Ko je zadeva "na vrhuncu" pozornosti medijev, se zanjo najbolj zanimajo tudi politiki. To pravilo velja izkoristiti za lobiranje. Čez nekaj časa pa se pojavi nova zadeva, in prvotna izzveni ter počasi postane prepuščena pozabi. Ko mediji začno zadevi namenjati manj prostora, se tudi politiki zanjo ne zanimajo več.

Zelo ugodo obdobje za lobiranje je v času priprave zakonov. Takrat je največ možnosti za vplivanje na vsebino. Na vsebine veliko lažje vplivamo takrat, ko še niso dokončno izoblikovane. Zakone pripravlja vlada oziroma vladne službe. Za pisanje zakonov vlada pogosto najame zunanje izvajalce. Marsikje in marsikdaj se je vsaj zdelo, da je bilo lobiranje prisotno že pri odločanju o izbiri pripravljalca zakona ali predpisa. Možnost za 
Lobiranje: Določanje dinamike lobiranja

vplivanje na vsebino obstaja tudi v času parlamentarne procedure. Lobiranju so podvrženi politiki in njihovo osebje.

Seveda se lobira tudi, ko se ne dogaja nič od naštetega. To pa še ne pomeni, da lobiranje udi takrat ne bi moglo biti uspešno. 


\section{IZBOR METOD LOBIRANJA}

Schendelen (2013) pravi, da je pri izvajanju lobiranja v organih Evropske skupnosti možno opaziti troje:

- vnemo (oziroma gorečnost) in doslednost;

- vnemo, ne pa doslednosti;

- niti gorečnosti niti doslednosti.

Pravi, da je za uspeh najbolj pomembna doslednost, saj ta spodbuja gorečnost in končno zmago. Z drugimi besedami to pomeni, da je pri lobiranju treba biti dosleden in vztrajen.

Poznamo metode direktnega in indirektnega lobiranja (Schendelen, 2013):.

Direktno lobiranje je »mehko« lahko pa zelo »trdo« prepričevanje ljudi, ki o nečem odločajo. K direktnemu lobiranju štejemo:

- osebna srečanja;

- posredovanja po telefonu;

- vabilo na formalni obisk;

- pošiljanje pisem posameznikom;

- pošiljanje odprtih pisem (posameznikom ali ustanovam);

- pošiljanje pisem, katere podpiše več podpisnikov;

- "zasedbo" telefonske številke oziroma drugih elektronskih naslovov;

- peticije;

- izdajanje publikacij, video vsebin, ipd.;

- kazenske ovadbe in sprožanje zadev na sodiščih;

- drugo.

K indirektnemu lobiranju pa štejemo:

- lobiranje preko prijateljev znotraj skupine odločevalcev;

- članstvo v interesnih združenjih;

- lobiranje preko objav na družabnih omrežjih;

- kampanje v medijih;

- ciljno usmerjene politične kampanje;

- generiranje "zadev" v medijih;

- pritisk organizacij civilne družbe;

- pritisk "vzporednih" političnih organizacij;

- masovne demonstracije;

- stavke;

- ustanovitev lastne politične stranke;

- spletke. 
Osebno srečanje slej ko prej ostaja najučinkovitejši način za predstavitev stališč. Po drugi strani je lahko tudi problematično. Politiki so namreč dnevno izpostavljeni številnim zahtevam, prošnjam in pobudam. Zato $\mathrm{v}$ javnosti pogosto obstaja prepričanje, da politiki zlahka obljubijo in težko naredijo. Del resnice je v veliki komunikacijski obremenitvi politikov.

Če se z želenim politikom vendarle uspemo sestati, mu zadevo predstavimo čim bolj na kratko, brez zahajanj v podrobnosti, vendar celovito. Pripravimo se, da odgovorimo na morebitna vprašanja. Pustimo tudi kratek pisni opis zadeve. Ne zahtevajmo impulzivnih in naglih odločitev in dejanj. K osebnim srečanjem sodijo tudi povabila na obisk.

Posredovanja po telefonu so lahko prav tako pomembna, kot osebna srečanja. Telefonski klic traja krajši čas, kot osebno srečanje, zato je ta metoda dokaj priljubljena in pogosto tudi zelo učinkovita. Njihova slabost je $\mathrm{v}$ tem, da imajo ljudje mnogo več telefonskih klicev, kot osebnih srečanj. Zato na telefonske klice višjih uradnikov navadno odgovarjajo nižji uradniki. Pri tem obstaja nevarnost, da sporočilo ne prenesejo do želene osebe. Temeljno pravilo posredovanj po telefonu je, da pri klicanju nikoli ne smemo biti nevljudni. Če ugotovimo, da nekdo ne želi kontaktirati z nami, ga ne nadlegujemo in ga ne kličemo za vsako ceno.

Pisanje pisem in pošiljanje elektronske pošte je zelo pogosta metoda lobiranja. Je manj učinkovita od osebnih kontaktov. Mnogi raje berejo pisma in elektronsko pošto, kot se osebno srečujejo s pogosto nepoznanimi ljudmi. Po drugi strani pa mnogi dnevno prejemajo na desetine elektronskih sporočil in jih zato sploh ne utegnejo prebrati. Če se poslužujemo pisem, naj pismo ne bo daljše od dveh strani. V prvi fazi priložimo zgolj tiste priloge, ki so res nujno potrebne za razumevanje problema. Pisma lahko pošiljamo na enega ali na več naslovov. Če pismo pošiljamo na več naslovov moramo paziti, da so vsi poslani izvodi lastnoročno podpisani, tudi če je naslovnikov več. Vsako sporočilo mora biti naslovljeno osebno na prejemnika. Tako vsak naslovnik dobi občutek, da se obračamo ravno nanj. Izogibamo se pošiljanju fotokopij.

Tudi v Sloveniji so že bili primeri "zasedbe" telefonske številke in elektronskih naslovov. Gre za to, da člani določene skupine v nekem obdobju neprestano kličejo določeno telefonsko številko (določeno institucijo ali osebo) s ciljem doseči neko ravnanje. Tako ravnanje se pogosto šteje kot reakcija na frustracijo, oziroma kot reakcija na neko ravnanje. Praksa doma in $\mathrm{v}$ tujini kaže, da je tako ravnanje popolnoma kontraproduktivno. Pogosto povzroči še večja neskladja in celo sovražnost med dvema stranema.

Praksa kaže, da je pisanje peticij ena od manj učinkovitih metod. Navadno se tega lotevajo manj izkušeni. Politiki peticij zelo pogosto sploh ne preberejo.

Tako praksa, kot tudi teorija (Schendelen, 2013) kot eno od metod lobiranja prepozna tudi vlaganje zadev na sodišča. 
Tožbe so pravno sredstvo, vendar se jih organiazcije in posamezniki poslužujejo tudi v procesih lobiranja. Vlaganje tožb na sodišča v funkciji lobiranja ima namen:

- upočasnitve postopka političnega ali upravnega odločanja;

- spremembe politične ali upravne odločitve;

- ustrahovanja nosilcev političnih in upravnih odločtev.

Kazenske ovadbe so instrument pravne države. Čeprav je kriva ovadba kaznivo dejanje, se organizacije in posamezniki vlaganja kazenskih ovadb poslužujejo tudi v procesih lobiranja. Nenazadnje se to lahko stori tudi v anonimni obliki. Kazenske ovadbe v funkciji lobiranja so praviloma vložene malo pred odločanjem. Praviloma se sporočilo o vložitvi kazenske ovadbe še pred odločanjem na nek način posreduje do tistih, ki odločajo. Zaznava takega sporočila pri odločevalcih povzroči čustvo strahu, negotovosti in dvoma. $\mathrm{S}$ tem vpliva na odločitev. Funkcija vlaganja kazenskih ovadb je tudi v izločitvi in diskreditaciji neugodnih odločevalcev.

Od indirektnih metod lobiranja je zagotovo najpomembnejše delo z mediji. Politiki so zelo podvrženi vplivu medijev. Mediji imajo na politike neverjeten vpliv. Objave v medijih so zelo pogosta metoda lobiranja.

Lahko se zgodi, da je za dosego cilja organizacije potrebna zamenjava politične oblasti. $\mathrm{V}$ takih primerih se politik (ali stranka) in organizacija dogovorijo za skupen nastop pri ciljno usmerjeni politični kampanji. Gre za to, da opredelijo:

- načini medsebojnega podpiranja;

- vsebino in metode sodelovanja pred volitvami;

- vsebino in metode (ne)pojavljanja v javnosti;

- cilje delovanja v primeru zmage na volitvah;

- drugo.

Seveda dogovor navadno ostane največja poslovna skrivnost obeh partnerjev. Bistvo vsega je, da relativno majhna skupina volivcev lahko odločujoče vpliva na rezultate volitev. Posamezna organizacija lahko pomaga vplivati na odločitev te skupine volivcev.

Organizacije civilne družbe so združenja, ki so po statusu društva in klubi. Njihovo področje delovanja praviloma ni politično. Vendar politične stranke po potrebi tako obliko združevanja ljudi uporabijo za podporo svojemu delovanju. To storijo tako, da vplivajo na nastanek in delovanje novih ali že obstoječih organizacij civilne družbe. Pod fasado navidezne politične neodvisnosti in neopredeljenosti se promovira neka politična opcija. Podobno že obstoječe politične stranke lahko posredno ali neposredno podpirajo ustanavljanje vzporednih političnih strank.

Masovne demonstracije zelo redko nastanejo spontano. Navadno so organizacijsko, logistično in materialno podprte s strani interesnih skupin. Pred demonstracijami se običajno zgodi nek dogodek, ki predstavlja povod. Povod mora biti take narave, da ga ljudje zaznajo in da pri njih sproži čustva. Nastanek čustva je pogoj, da se bodo ljudje 
Lobiranje: Izbor metod lobiranja

demonstracij sploh udeležili. Sploh ni nujno, da je povod neposredno povezan s cilji demonstracij. Dejanski cilj demonstracij ni nujno identičen deklariranemu cilju demonstracij. 


\section{IZBOR TAKTIK LOBIRANJA}

Taktika $^{35}$ pomeni način ravnanja za dosego kakega cilja. Z ustrezno taktiko je treba poskusiti doseči pripravljenost tistega, ki o zadevi odloča, da bo ravnal na želen način. Izbor taktike pomeni izbiro in udejanjenje načina motiviranja tistega, ki o nečem odloča. Med procesom lobiranja lahko izberemo različne taktike, kot:

- dajanje komplimentov ravnanju politika;

- sklicevanje na ideologijo;

- sklicevanje na zakone, resnico in pravico;

- sklicevanje na ureditev v drugih državah;

- zadovoljevanje osebnih interesov posameznika;

- ponudba pomoči;

- grožnje;

- drugo.

Dajanje komplimentov ravnanju politika je vedno bolj ali manj učinkovito na začetku lobiranja. Pohvale stališčem in ravnanju politika so učinkovite, če želimo z njim sodelovati daljše časovno obdobje. Vsak politik sčasoma postane znotraj samega sebe prepričan, da poskuša zgraditi boljši svet. Prepričan je, da ravna etično in pošteno. To moramo pohvaliti. Zavedati pa se moramo, da ima politični proces svojo logiko in da za etiko v njem pogosto ni prostora.

Nekateri politiki so poznani po tem, da je primarni element pri sprejemanju odločitev ideologija. Ideologija je sistem idej, ki predstavlja vodilo za družbeno delovanje. Nekateri politiki ideologiji dajejo prednost pred racionalnimi elementi. Nikakor ni produktivno niti poskušati spremeniti ideologije takih ljudi. Če pa je možno, se je v takih primerih dobro sklicevati na ideološko utemeljenost posamezne rešitve.

Že Aristotel je ugotovil, da je v politiki pogosto sklicevanje na zakone. Pogosto se sklicujemo na urejenost v drugih državah.

Lobist je vedno razpet med resnico in interesom. Pomembno pravilo lobiranja pravi, naj se lobist izogiba laganju in zavajanju. Če argumenti niso najbolj ugodni je bolje, da argumentom pripisujemo različen pomen oziroma najdemo zase ugodne interpretacije.

Osebni interes vsakega politika je participacija pri oblasti. V demokratičnih državah do uveljavitve tega interesa pride z izvolitvijo. Na izvolitev vpliva javno mnenje. Ljudje na volitvah se odločajo na podlagi konkretnih stališč in ravnanj politikov. Zato ima vsaka volilna kampanja povsem vsebinske teme. Če je možno, predstavimo uporabnost

${ }^{35}$ Slovar slovenskega knjižnega jezika. 
določene ideje za oblikovanje javnega mnenja. To taktiko navadno uporabimo $\mathrm{v}$ kombinaciji s kako drugo (npr.: sklicevanje na resnico in pravico).

Med procesom lobiranja politikom (npr. kandidatu stranke ali stranki) lahko ponudimo pomoč pri izvedbi volilne kampanje. Če se odločimo za to taktiko, moramo predhodno proučiti velikost vložkov, tveganja in verjetnost, da bo podprta opcija dobila dovolj glasov na volitvah. Pogosto se dogaja, da organizacije podprejo več političnih strank. Te za dvojno ali trojno "igro" organizacije seveda ne smejo vedeti.

Pri lobiranju se organizacije in posamezniki poslužujejo tudi groženj. To storijo, kadar neka politika noče sodelovati oziroma odkrito deluje proti njihovim interesom. Lahko "obljubijo" kampanjo proti določeni politiki. Tako taktiko uporabi, kdor čuti, da ima na razpolago dovolj resursov in znanja, da grožnje tudi uresniči. Če grožnje v primeru potrebe ne uresniči, izpade neverodostojno. $V$ takem primeru je bolje, da svoj trud vloži $\mathrm{v}$ dosego drugačnih ciljev. 


\section{IMPLEMENTACIJA}

Brez ustreznega planiranja dejavnosti lobiranja, je uspeh zgolj naključje. Vse dejavnosti lobiranja morajo biti skrbno premišljene in planirane.

Schendelen (2013) tako pravi, da lobisti oziroma naročniki v procesu lobiranja reagirajo na različne načine:

- Refleksne reakcije so posledica čustev. Značilne so za amaterje.

- Formalne reakcije so posledica upoštevanja pravil in hierahije inštitucij ter odločevalcev.

- Reakcije prilagojene odzivom uradnikov in odločevalcev se lahko skozi proces lobiranja spreminjajo.

- Svetovane reakcije so ravnanja, ki jih svetujejo konzultanti.

- Situacijske reakcije so reakcije, ki jih prilagodimo trenutnim situacijskim dejavnikom. Lahko se zgodi, da koga, s katerim se želimo pogovoriti, naključno srečamo. Seveda je treba izkoristiti vsako priložnost, zato svoje ravnaje v takem primeru prilagodimo trenutnim okoliščinam.

Planirati pomeni predvsem opredeliti proces lobiranja, kakor smo ga opisali. Seveda vseh podrobnosti ne moremo planirati, še zlasti ne dinamike doseganja ciljev. Vsekakor pa lahko opredelimo določene kontrolne točke. Dobro je, da določimo vmesne cilje in jih kontroliramo.

V fazi udejanjanja je treba skrbeti za:

- logistiko (to je priskrbo potrebnih virov);

- kontaktiranje z lobisti (motiviranje, sodelovanje pri sprejemanju odločitev v zvezi z lobiranjem.

- kontaktiranje $\mathrm{z}$ lobisti $\mathrm{V}$ smislu dajanja povratnih informacij naročniku lobiranja;

- po potrebi kontaktiranje s politiki;

- izvajanje administrativno-tehničnih opravil;

- drugo. 
PoSLOVNO KOMUNICIRANJE

Lobiranje 


\section{VREDNOTENJE REZULTATOV}

Med procesom lobiranja je pomembna tudi funkcija kontrole. Dobro je spremljati doseganje vmesnih in končnih ciljev lobiranja. Kontrolno funkcijo je treba izvajati že med samim procesom lobiranja.

Ob koncu pa je pomembno ugotoviti:

- stroške in koristi lobiranja;

- katere metode so nam prinesle želene in katere neželene učinke;

- katere taktike so se najbolj obnesle.

Z lobistom ne glede na to, kakšen je rezultat lobiranja ohranimo kontakte tudi po koncu projekta. 
PoSLOVNO KOMUNICIRANJE

Lobiranje 


\section{LITERATURA}



Aakhus. M. DiDomenico, S. (2016). Language and interaction in new-media environments. objavljeno v: Rocci, A. De Saussure, L. (2016). Verbal Communication. De Gruyter. Mouton.

Adi. A. Grigorek, G. Crowtherk, D. (2015). Corporate Social Responsibility in the Digital Age. Emerald. Bingley.

Ahava, L. (2014). The Digital Crown: Winning at Content on the Web. Elsevier. Amsterdam.

Aldrich, H. (1979). Organizations and Environments. Prentice-Hall. Englewood.

Andreassen, T. W. Lindestadk, B. (1998). Customer loyalty and complex services: The impact of corporate image on quality. customer satisfaction and loyalty for customers with varying degrees of service expertise. International Journal of Service Industry Management. 9(1), 7-23.

Aronson, E. Wilson, T. Akert, R. M. (2010). Social Psychology 7th edition. Pearson. New York.

Avgar, A. C. Lee, E. K. (2014). Social Capital in Negotiation: Leveraging the Power of Relational Wealth. objavljeno v: Benoliel. M. (2014). Negotiation Excellence: Successful Deal Making (2nd Edition). World Scientific. Hackensack. NJ.

Awais-Dean. N. (2016). Redressing the balance: dress accessories of the non-elites in Early Modern England. objavljeno v: Martin, T. F. Weetch, R. (2016). Dress and Society: Contributions From Archaeology. Oxbow Books. Oxford.

Baker, M. J. Saren, M. (2016). Marketing Theory: A Student Text. Sage. London.

Balbi, G. John, R. J. (2015). Point-to-point: telecommunications. objavljeno v Cantoni, L. Danowski, J. A. (2015):. Communication and Technology. De Gruyter Mouton. Berlin.

Balmer, J. M. T. Greyser, A. S. (2013). Revealing the Corporation. Routledge. London.

Benoit, W. L. Pang, A. (2008). Crisis communication and image repair discourse. objavljeno v: Hansen-Horn, T. L. Neff, B. D. (2008). Public relations: From theory to practice. Pearson. New York.

Benoliel, M. (2014). Negotiation Excellence: Successful Deal Making (2nd Edition). World Scientific. Hackensack. NJ.

Berger, P. L. Luckmann, T. (1966). The social construction of reality. Freeman. New York.

Bickley, G. (2012). Perceptions. Proverse Hong Kong. Hong Kong.

Bourdieu, P. (1986). The forms of capital. objavljeno v: Richardson, J. (ed.) (1986). Handbook of Theory and Research for the Sociology of Education. Greenwood. New York. 
Bouwen, P. (2009). The European Commission. objavljeno v: Richardson, J. J. Coen, D. (2009). Lobbying the European Union: Institutions. Actors. and Issues. Oxford University Press. Oxford.

Brajša, P. (1994). Managerska komunikologija. Gospodarski vestnik. Ljubljana.

Brassington, F. Pettitt, S. (1997). Principles of Marketing. Pitman Publishing. London.

Brewer, B. (2011). Perception and Its Objects. Oxford University Press. Oxford.

Brinley, T. (1993). The Industrial Revolution and the Atlantic Economy: Selected Essays. Routledge. London.

Brower, A. M. Nurius, P. (1993). Social Cognition and Individual Change: Current Theory and Counseling Guidelines. Sage. London.

Calhoun, C. (1992). Habermass and the Public Sphere. MIT Press. Cambridge.

Campbell, N. (2007). How Speech Encodes Affect and Discourse Information. objavljeno v: Esposito, A. et al. (2007). Fundamentals of Verbal and Nonverbal Communication and the Biometric Issue. IOS Press. NATO Security Through Science Series. Amsterdam.

Cantoni, L. (2015). Communication and Technology. De Gruyter Mouton. Berlin.

Carroll, A. (2008). A history of corporate social responsibility: Concepts and practices. V : Crane, A. McWilliams, A. Matten, D. Moon, J. Siegel, D. S. (eds.). The Oxford handbook of corporate social responsibility. Oxford University Press. Oxford.

Carroll, A. (1979). Three-dimensional conceptual model of corporate performance? Academy of Management Review. 4(4), 497-505.

Carroll, A. B. Shabana, K. M. (2010). The business case for corporate social responsibility: A review of concepts. research and practice. International Journal of Management Reviews. 12(1), 85 -105

Castells, M. Aoyama, Y. (1994). Paths Toward the Information Society: Employment Structure in G7 Countries. International Labour Review. 133, 1.

Chai Lee Goi. (2009). A Review of Marketing Mix: 4Ps or More?. International Journal of Marketing Studies. 1(1).

Chaney, P. (2009). The Digital Handshak: Seven Proven Strategies to Grow Your Business Using Social Media. Wiley. Hoboken.

Ciot, M. G. (2014). Negotiation and Foreign Policy Decision Making. Cambridge Scholars Publishing. Newcastle.

Coombs, W. \& Holladay. S. J. (2010). The Handbook of Crissis Communication. Wiley. Blackwell.

Coombs, W. (2007). Protecting Organization Reputations During a Crisis: The Development and Application of Situational Crisis Communication Theory. Corporate Reputation Rev. 10(3), 163-176. 
Coombs, W. (2015). Ongoing Crissis Communication. Sage. London.

Corrigan, P. (2008). The Dressed Society : Clothing. the Body and Some Meanings of the World. Sage. London.

Crawford, W. (2014). Successful Social Networking in Public Libraries. ALA Editions. Chicago.

Craze, R. (1994). Graphology for beginers. Hodder\&Stoughton. London.

Däbritz, M. (2014). Pimp your Corporate Identity: Bewegtbildkommunikation im Internet für den besseren Auftritt. Diplomica Verlag. Hamburg.

Dahlsrud, A. (2008). How corporate social responsibility is defined: An analysis of 37 definitions. Corporate Social Responsibility and Environmental Management. 15(1), 1-13.

De Risio, A. (2014). Social Cognition . Everyday Problems and Working Capacity in Persons with Schizophrenia : Outcomes from the Real World. objavljeno v: Nasato, S. R. (2014). Advances in Social Cognition Research. Nova Science Publishers. New York.

Demmerling, T. (2015). Corporate Social Responsibility Overload? Intention. Abuse. Misinterpretation of CSR From the Companies ' and the Consumers 'Point of View. Anchor Academic Publishing. Hamburg.

Devetak, G. (1999). Temelji trženja in trženjska zasnova podjetja. Visoka šola za management v Kopru. Koper.

Elsbach, K. D. (2013). Organizational Perception Management. Routledge. New York.

Enkelmann, N. B. (1997). Moč retorike. Vernar consulting. Kranj.

Esposito, A. (2007). Fundamentals of Verbal and Nonverbal Communication and the Biometric Issue. NATO Public Diplomacy Division. Amsterdam.

Esposito, A. Marinaro, M. (2007). What Pauses Can Tell Us about Speech and Gesture Partnership. objavljeno v: Esposito, A. et al. (2007). Fundamentals of Verbal and Nonverbal Communication and the Biometric Issue. IOS Press. NATO Security Through Science Series. Amsterdam.

Evanschitzky, H. Groening, C. Mittal. V. (2011). How Employer and Employee Satisfaction Affect Customer Satisfaction: An Application to Franchise Services. Journal of Service Research. 14(29), 136-148.

Feryal, C. C. (2012). Personality Traits: Reflections in the Brain. objavljeno v: Arroyo, D. Delgadillo, E. (2012: Encyclopedia of Personality Research. Nova Science. New York.

Findlay, R. (et. al. - ed) (2006). Eli Heckscher. International Trade. and Economic Historyk. The MIT Press. Massachusetts.

Fortune magazine (izdaje letnika 1997. 1998. 1999. 2000). 
Friedman, M. (1970). The Social Responsibility of Business Is to Increase Its Profits. The New York Times Magazine. September 13th, 1970.

Fujun, L. Griffin, M. Babin, B. J. (2009). Journal of Business Research. 62 (10), 980986.

Gallman, R. E. Weiss, J. T. (1969). The Service Industries in the Nineteenth Century. In Production and Productivity in the Service Industries. ed. Victor, R. Fuchs,, 287352. Columbia University Press. New York.

Glozman, E. Barak-Corren, N. Yaniv, I. (2014). False Negotiations. The Art and Science of Not Reaching an Agreement. Journal of Conflict Resolution. 59(4), 671-697

Goldstein, E. B. (2009). Sensation and Perception. Cengage Learning.

Goldstein, E. B. (2010). Encyclopedia of Perception. SAGE. Thousand Oaks.

Grabnar, B. (1991). Retorika. Državna založba Slovenije. Ljubljana.

Gray, J. Laidlaw, H. (2004). Improving Measurement of Communication Satisfaction. Management Communication Quarterly. 17(3), 425-448.

Gruban, B. Verčič, D. Zavrl, J. (1997). Pristop $k$ odnosom z javnostmi. Pristop. Ljubljana.

Grunig, J. E. (2009). Paradigms of global public relations in an age of digitalisation. Retrieved March 9. 2017 from http://praxis.massey.ac.nz/prism_online_journ.html

Grunig, L. A. Grunig, J. E. Dozier, D. M. (2002). Excellent Public Relations and effective organizations: A study of communication management in three countries. Lawrence Erlbaum Associates, Inc. Mahwah. New York.

Guimard, A. (2008). Investor Relations. Macmillian. Hampshire.

Gülçlimen, Y. Gizem, K. Gungor, H. (2010). Buyer-Seller Negotiations: A Comparison of Domestic and International Conditions in a Pilot Study with International Business Students. Psychological Reports. 106 (3), 671-678.

Gunning, E. (2012). Public Relations: A Practical Approach. Gill\& Macmillan. Dublin.

Habermas, J. (1997). Between Facts and Norms: Contributions to a Discourse Theory of Law and Democracy. Polity. Cambridge.

Halford, G. S. Phillips, S. Andrews, G. Wilson, W. H. (2014). Categorizing Cognition: Toward Conceptual Coherence in the Foundations of Psychology. The MIT Press. Massachusetts.

Hall, J. A. Knapp, M. L. (2013). Welcome to the Handbook of Nonverbal Communication. objavljeno v: Knapp, M. L. Hall, J. A. (2013). Nonverbal Communication. De Gruyer. Boston.

Hallahan, K. (1999). Seven Models of Framing: Implications for Public Relations. Journal of public relations research. 11 (3), 205-242. 
Harrison, S. (1995). Public Relations. Routledge. London.

Harsh, V. (2010). Branding Demystified: Plans to Payoffs. Sage. New Delhi.

Härtel, C. E. J. Zerbe, W. J. Ashkanasy, N. M. (2015). New Ways of Studying Emotions in Organizations. Emerald. Bingley.

Hashim Zameer, Anam, Tara. Uzma Kausar. Aisha Mohsin. (2015). Impact of service quality. corporate image and customer satisfaction towards customers' perceived value in the banking sector in Pakistan. International Journal of Bank Marketing. 33(4), 442-456.

Heath, R. L. (2010). Crisis Communication: Defining the Beast and De-marginalizing Key Publics. objavljeno v: Coombs, T. W. Holladay, S. J. (2010). The Handbook of Crissis Communication. Wiley. Blackwell.

Hecht, M. L. (1978). Measures of communication satisfaction. Human communication research. 4(4), 350-368.

Heger, L. L. Jung, D. F. (2015). Negotiating with Rebels. The Effect of Rebel Service Provision on Conflict Negotiations. 61(6), 1203-1229.

Herbst, D. (2009). Corporate Identity. Cornelsen Verlag. Berlin.

Heskett, J. W. E. Sasser, J. Schlesinger, L. (1997). The Service Profit Chain: How Leading Companies Link Profit and Growth to Loyalty, Satisfaction and Value. Free Press. New York.

Heyman, B. (2009). Digital Engagement: Internet Marketing That Captures Customers and Builds Intense Brand Loyalty. American Management Association. New York.

Hofstede, G. (2001). Culture's Consequences: Comparing Values, Behaviors, Institutions and Organizations Across Nations. 2nd Edition. Sage. Thousand Oaks.

Hoss, S. (2016). The Roman military belt - a status symbol and object of fashion objavljeno v: Martin, T. F. Weetch, R. (2016). Dress and Society: Contributions From Archaeology. Oxbow Books. Oxford.

Huang, Y. H. (2004). PRSA. Scale development for exploring the impetus of Public Relations strategies. Journalism and Mass Communication Quarterly. 8(2), 307326.

Hunt, T. Grunig, J. E. (1994). Tehnike odnosov z javnostmi. DZS. Ljubljana.

Hwang, S. (2012). The strategic use of Twitter to manage personal public relations. Public Relations Review. 38(1), 159-161.

Ingram, R. (2015). Understanding Emotions in Social Work : Theory. Practice and Reflection. McGraw-Hill. Berkshire.

ISO 26000

Jablin, F. (1987). Handbook of Organizational Communication. Sage Publications Inv. Newbury Park. 
Jain, N. Sethi, A. Mukherji, S. (2009). Impact of Communication during Service Encounters on Customer's Perception of Organization Image. Paradigm. 13(1), 56-65.

Jalbert, T. Rao, R. Jalbert, M. (2002). Does School Matter? An Empirical Analysis Of CEO Education, Compensation And Firm Performance. International Business \& Economics Research Journal (IBER). 1(1), 83-98.

Jalbert, T. Rao, R. Jalbert, M. (2010). Does Educational Background Affect CEO Compensation and Firm Performance?. The Journal of Applied Business Research. 27(1), 15-40.

Jefkins, F. (1998). Public Relations. Financial Times Management. London.

Jubb, P. (1999). Whistleblowing: A Restrictive Definition and Interpretation. Journal of Business Ethics. 21(1), 77-94.

Kahn, W. A. (1990). Psychological conditions of personal engagement and disengagement, Academy of Management Journal. 33(4), 692-724.

Kandampully, J. Suhartanto, D. (2000). Customer loyalty in the hotel industry: the role of customer satisfaction and image. International Journal of Contemporary Hospitality Management. 12(6), 346-351.

Kendon, A. (2007). Some Topics in Gesture Studies. objavljeno v: Esposito, A. et al. (2007). Fundamentals of Verbal and Nonverbal Communication and the Biometric Issue. IOS Press. NATO Security Through Science Series. Amsterdam.

Kenny, J. (2016). Excellence Theory and its Critics: A literature rewiew critiquing Gruning's strategic mangement of public relations paradigm. Asia Pacific Public Relations Journal. 17(2), 78-91.

Kitchener, R. F. O'Donohue. W. T. (1999). Handbook of Behaviorism. Academic Press. San Diego.

Knapp, M. L. (2013). Establishing a domain for the study of nonverbal phenomena: $e$ pluribus unum. objavljeno v: Knapp, M. L. Hall, J. A. (2013). Nonverbal Communication. De Gruyer. Boston.

Knapp, M. L. Hall. J. A. (2013). Nonverbal Communication. De Gruyer. Boston.

Knox, A. (2016). Middle Anglo-Saxon dress accessories in life and death: expressions of a worldview. objavljeno v: Martin, T, F. Weetch, R. (2016). Dress and Society: Contributions From Archaeology. Oxbow Books. Oxford.

Kotler, P. (1989) : Upravljanje marketingom I. in II. Informator. Zagreb.

Kotler, P. (1996). Marketing management. Slovenska knjiga. Ljubljana.

Koys, D. J. (2001). The effects of employee satisfaction. organizational citizenship behavior, and turnover on organizational effectiveness: A unit-level longitudinal study. Personnel Psychology. 54(1), 101-114 
Kraus, J. (2014). Rhetoric in European Culture and Beyond. Karolinum Press-Charles University in Prague. Prague.

Kruse, K. (2012). What Is Employee Engagement. Forbes. 22.7.2012

LePla, F. J. Parker, L. M. (1999). Integrated Branding: Becoming Brand-driven Through Companywide Action. Greenwood Publishing Group. Westport.

Liu, A. Chua, R. Enns, J. T. (2007). Attention for perception and action: task interference for action, planning, but not for online control. Experimental Brain Research. 185(4), 709-717.

Liu, M. (2014). Planning and Preparation for Effective Negotiations. objavljeno v: Benoliel, M. (2014). Negotiation Excellence: Successful Deal Making (2nd Edition). World Scientific. Hackensack. NJ.

Machiavelli, N. (1966). Vladar. Mladinska knjiga. Ljubljana.

Manyikla, J. et. Al. (2012). Manufactoring the Future: The next era of global growth and innovation. McKinsey Global Institute.

Marcum, J. A. (2014). Theory of Everything Cognitive: from Neurons to Extended Cognition. objavljeno v: Rosenfield, E. P. (2014). New Developments in Cognitive Systems Research. Hauppauge. Nova Science Publishers. New York.

Mathieson, R. (2010). The On-Demand Brand: 10 Rules for Digital Marketing Success in an Anytime, Everywhere World. AMACOM. New York.

Mazzei, A. Ravazzani, S. (2015). Internal Crisis Communication Strategies to Protect Trust Relationships: A Study of Italian Companies. International Journal of Business Communication. 52(3), 319-337.

McDonald, P. Thompson, P. (2016). Social Media(tion) and the Reshaping of Public/Private Boundaries in Employment Relations. International Journal of Management Reviews. 18(1), 69-84.

McElhaney, K. A. (2008). Just Good Business: The Strategic Guide to Aligning Corporate Responsibility and Brand. Berrett-Koehler Publishers, Inc. San Francisco.

McKnight, D. A. (2013). The Zen of executive presence. DAMStyle. Cleveland.

McNeill, D. (2007). Gesture and Thought. objavljeno v: Esposito. A. et al. (2007). Fundamentals of Verbal and Nonverbal Communication and the Biometric Issue. IOS Press. NATO Security Through Science Series. Amsterdam.

Miletsky, J. (2009). How You Define a Brand. objavljeno v: Miletsky, J. I. Smith, G. (2009). Perspectives on Branding. Mass: Course PTR. Boston.

Miletsky, J. (2009a). Is There a Difference Between a Brand and a Company? What about a Brand and Product?. objavljeno v: Miletsky, J. I. Smith, G. (2009). Perspectives on Branding. Mass: Course PTR. Boston. 
Miller, K. (2003). Encyclopedia and Dictionary of Medicine, Nursing, and Allied Health, Saunders. Elsevier. Amsterdam.

Minkiewicz, J. Evaans, J. Bridson, K. and Mavondo, F. (2011). Corporate image in the leisure services sector. Journal of Services Marketing. 25(3), 190-201.

Mitkova, A. Drozdstoj, S: (2014). Prospective Fields of Applied Cognitive Systems Research. objavljeno v: Rosenfield, E. P. (2014). New Developments in Cognitive Systems Research. Hauppauge. Nova Science Publishers. New York.

Moshe, M. (2014). The Emotions Industry. Nova Science. New York.

Novak, B. (1999). Krizno komuniciranje. Gospodarski vestnik. Ljubljana.

Omilion-Hodges, L. M. McClain, K. L. (2016). University use of social media and the crisis lifecycle: Organizational mesSages. first information responders' reactions. reframed mesSages and dissemination patterns. Computers in Human Behavior. $54,630-638$.

Ottaviani, C. Shapiro, D. Goldstein, I. Gofman, V. (2012). Personality Traits and Daily Moods. objavljeno v: Arroyo, D. Delgadillo, E. (2012: Encyclopedia of Personality Research. Nova Science. New York.

Paddock, E. L. (2014). The Role of Gender in Negotiation. objavljeno v: Benoliel, M. (2014). Negotiation Excellence: Successful Deal Making (2nd Edition). World Scientific. Hackensack. NJ.

Palumbo, A. (2014). Modern Law of Sales in the United States. ELSEVIR. Hague.

Pashler, H. E. (2013). Encyclopedia of the Mind. Sage. Los Angeles.

Pennington, D. C. (2000). Social Cognition. Routledge. London.

Petrone, C. Perrier, P. Fuchs, S. Pape, D. (2016). Individual Differences in Speech Production and Perception. Peter Lang. Frankfurt am Main.

Podbregar, I. Mulej, M. Pečan, S. Podbregar,N. Ivanuša, T. (2010). Informacije kot »bojna" podpora kriznemu odločanju. krizni komunikaciji in delovanju. Zavod za varnostne strategije. Ljubljana.

Poizner, A. (2012). Clinical Graphology: An Interpretive Manual for Mental Health Practitioners. Charles Thomas Publisher. Springfield. Illinois.

Polić, V. (1976). Planiranje kadrova i obrazovanja. Školska knjiga. Zagreb

Price, C. (2010). Emotion. The Open University. Milton Keynes.

Prokopis, K. Theodoridis, K. Chatzipanagiotou, C. (2009). Store image attributes and customer satisfaction across different customer profiles within the supermarket sector in Greece. European Journal of Marketing. 43 (5/6), 708-734.

Redding, W. C. (1999). Communication research and the 'rhetorical environment. Communication Studies. 50(4), 337-351.

Regester, M. (1997). Risk issues and crisis management. Kogan Page. London. 
Rhee, Y. (2002). Global Public Relations: A Cross-Cultural Study of the Excellence Theory in South Korea. Journal of Public Relations Research. 14(3), 159-184.

Richardson, J. J. Coen, D. (2009). Lobbying the European Union: Institutions, Actors, and Issues. Oxford University Press. Oxford.

Robertson, E. (2005). Placing leaders at the heart of organizational communication. Strategic Communication Management. 9(5), 34.

Rocci, A. Saussure, L. (2016). Verbal Communication. De Gruyter. Berlin.

Rosario González-Rodrígueza, M. Carmen Díaz. F. Simonettib, B. (2015). The social. economic and environmental dimensions of corporate social responsibility: The role played by consumers and potential entrepreneurs. International Business Review. 24(5), 836-848

Rose, E. (2013). Access denied: Employee control of personal communications at work. Work, Employment and Society. Retrieved April 2. 2017 from http://journals.Sagepub.com/doi/abs/10.1177/0950017012460329

Rosenfield, E. P. (2014). New Developments in Cognitive Systems Research. Nova Science Publishers. New York.

Ryan, T. M. Jacobs, C. A. (2005). Using Investor Relations to Maximize Equity Valuation. Wiley. Hoboken. N.J.

Rybalko, S. Seltzer, T. (2010). Dialogic communication in 140 characters or less: How Fortune 500 companies engage stakeholders using Twitter. Public Relations Review. 36(4), 336-341.

Sabaté, F. (2015). Conditioned Identities: Wished-for and Unwished-for Identities. Peter Lang. Frankfurt am Main.

Saee, J. (2008). Best practice in global negotiation strategies for leaders and managers in the 21st century. Journal of Business Economics and Management. 9(4), 309318

SAZU (1975). Slovar slovenskega knjižnega jezika. SAZU. Ljubljana.

Schendelen, M. P. C. M. van. (2005). Machiavelli in Brussels: The Art of Lobbying the EU. Amsterdam University Press. Amsterdam.

Schendelen, M. P. C. M. van. (2013). The Art of Lobbying the EU: More Machiavelli in Brussels. Revised Edition. Amsterdam University Press. Amsterdam.

Sema Hande Ogutcu-Fu (2016). Outside the Battlefield: In-Group Political Dynamics of Civil Conflict Negotiations and Settlements. Political Research Quarterly. 69(3), 403-417.

Sha, B. L. (2009). Exploring the Connection Between Organizational Identity and Public Relations Behaviours: How Symmetry Trumps Conservation in Engendering Organizational Identification. Journal of Public Relations Research. 21(3), 295-317. 
Sha,. B. L. (2006). Cultural Identity in the Segmentation of Publics: An Emerging Theory of Intercultural Public Relations. Journal of Public Relations Research. $18(1), 45-65$.

Shapiro, D. L. (2014). The Emotional Underbelly of Collaboration: When Politics Collide with Need. objavljeno v: Benoliel, M. (2014). Negotiation Excellence: Successful Deal Making (2nd Edition). World Scientific. Hackensack. NJ.

Sherin, A. (2011). Design Elements. Color Fundamentals : A Graphic Style Manual for Understanding How Color Impacts Design. Rockport Publishers. Beverly. Mass.

Siitonen, M. (2015). Communication in video games: From players to player communities. objavljeno v Cantoni, L. Danowski, J. A. (2015):. Communication and Technology. De Gruyter Mouton. Berlin.

Slade, C. (2016). Creating a Brand Identity: A Guide for Designers. Laurence King Publishing. London.

Slatkin, A. A. (2015). Crisis Negotiation for Law Enforcement. Corrections. and Emergency Services: Crisis Intervention As Crisis Negotiation. Charles C. Thomas. Springfield. Illinois.

Slyter, S. (1995). Forensic Signature Examination. Charles Thomas Publisher. Springfield. Illinois.

Splichal, S. (1999). Public OPinion: Developments and Controversies in the Twentieh Century. Rowman\&Littlefield Publishers, Inc. Oxford.

Stearns, P. N. Matt, S. J. (2014). The History of Emotions. University of Illinois Press. Urbana.

Steinel, W. Abele, A. E. De Dreu, C. (2007). Effects of Experience and Advice on Process and Performance in Negotiations, Group Processes \& Intergroup Relations. 10(4), 533-550.

Stewart, M. C. \& Wilson B. G. (2016). The dynamic role of social media during Hurricane-Sandy: An introduction of the STREMII model to weather the storm of the crisis lifecycle. Computers in Human Behavior. 54, 639-646.

Storozhuk, A. (2010). Color: Ontological Status and Epistemic Role. Nova Science Publishers. New York.

Stuhlmacher, A. F. Adair, C. K. (2014). Personality and Negotiation., Benoliel. M. (2014). Negotiation Excellence: Successful Deal Making (2nd Edition). World Scientific. Hackensack. NJ.

Syme, C. (2014). Monitoring social media to prevent a crisis. Social Media Today. $\begin{array}{llll}\text { Retrieved } & \text { March } & 2017 & \text { from }\end{array}$ http://www.socialmediatoday.com/content/monitoring-social-media-preventcrisis

Tagiuri, R. (1968). The concepts of Organizational climate. Harward University Press. Boston. 
Tardini, S. Cantoni, L. (2015). Hypermedia. internet and the web. objavljeno v: Cantoni, L. (2015). Communication and Technology. De Gruyter Mouton. Berlin.

Tatham, M. Morton, K. (2011). A Guide to Speech Production and Perception. Edinburgh University Press. Edinburgh.

Tench, R. Carayol, V. Ordeix, E. (2015). Public Relations, Values and Cultural Identity. Peter Lang. Frankfurt am Main.

Trstenjak, A. (1971). Oris sodobne psihologije I.- Teoretična psihologija. Založba Obzorja. Maribor.

Trstenjak, A. (1971). Oris sodobne psihologije II. - Uporabna psihologija. Založba Obzorja. Maribor.

Trstenjak, A. (1976). Človek in barve. Dopisna delavska univerza Univerzum. Ljubljana.

Trstenjak, A. (1986). Človek in njegova pisava. Centralni zavod za napredek gospodinjstva. Ljubljana.

Trstenjak, A. (1996). Psihologija barv. Institut Antona Trstenjaka. Ljubljana.

Tukiainen, T. (2001). An agenda model of organisational communication. Corporate Communications. 6(1), 47.

Uredba o ratifikaciji madridskega aranžmaja o mednarodnem registriranju znamk z dne 14. aprila 1891. revidiranega 14. decembra $1900 \mathrm{v}$ Bruslju. 2. junija $1911 \mathrm{v}$ Washingtonu. Uradni list SFRJ številka 2/1974.

Usui, K. (2008). The Development of Marketing Management: The Case of the USA, C. 1910-1940. Ashgate Publishing Company. Hampshire.

Velasquez, G. M. (1992). Busines Ethics: Concepts and Case. New Jersey: Prentice-Hall. New York.

Verčič, D. Grunig, J. E. (1998). Izvori teorije odnosov z javnostmi v ekonomiji in strateškem managementu. Teorija in praksa. Ljubljana.

Verčič, D. Gruning, J. E. (1998). Izvori teorije odnosov z javnostmi v ekonomiji in strateškem managementu. Teorija in praksa. Ljubljana.

Vila, A. (1994). Organizacija in organiziranje. Moderna organizacija. Kranj.

Vukadinović, R. (1994). Diplomacija. Arah Consulting d.o.o. Zagreb.

Wallerstein, I. M. (2011). The Modern World-System II: Mercantilism and the Consolidation of the European World-Economy. 1600-1750 University of California Press. Berkeley.

Watts, D. (1997). Political communication today. Manchaster University Press. Manchaster/New York. (ameriška izdaja).

Weitz, B. A. Wensley, R. (2002). Handbook of Marketing. Sage. London.

Wilkin, N. (2016). Combination. composition and context: readdressing British Middle Bronze Age ornament hoards (c. 1400-1100 cal. BC). objavljeno v: Martin, T. F. 
Weetch, R. (2016). Dress and Society: Contributions From Archaeology. Oxbow Books. Oxford.

Williams, S. J. (2015). Panacea for the Public Sphere? The Use of Social Media in the Public Sector in the UK. objavljeno v: Tench, R. Carayol, V. Ordeix, E. (2015). Public Relations, Values and Cultural Identity. Peter Lang. Frankfurt am Main.

Winer, R. S. (ed.). Neslin. S. A. (ed.) (2014). The History of Marketing Science. World Scientific / Now Publishers. London

Winkler, I. (2013). Management Symbolism and Symbolic Action. objavljeno v: Kessler, E. H. (2013). Encyclopedia of Management Theory. Sage. Thousand Oaks. California.

Wymbs, C. (2011). Digital marketing: The time for a new "Academic Major" has arrived. Journal of Marketing Education. 33(1), 93-106.

Young, P. (2015). A History of the Future Concepts for Telling the Story of Online PR. objavljeno v: Tench, R. Carayol, V. (eds.). Public Relations. Values and Cultural Identity. Peter Lang. Brusseles.

Zetter, L. (2008). Lobbying: The Art of Political Persuasion. Harriman House. Petersfield. 


\section{ELEKTRONSKI VIRI}



http://data.worldbank.org

http://dictionary.cambridge.org

http://ec.europa.eu/eurostat

http://globeproject.com/

http://www.dialogos.si

http://www.efqm.org

http://www.fortune.com

http://www.gallup.com

http://www.jdpower.com

http://www.lek.si

http://www.luxottica.com/en

http://www.macmillandictionary.com

http://www.nato.int

http://www.nokia.com

http://www.reuters.com

http://www.samsung.com

http://www.swatchgroup.com/en/brands_and_companies/production

http://www.theacsi.org

http://www.zeta.org.au

https://www.fairtrade.net

https://www.fema.gov

https://www.iso.org/

https://www.unglobalcompact.org

https://www.volkswagenag.com/ 
Elektronski viri 
PoSLOVNO KOMUNICIRANJE

M. Ferjan

\section{STROKOVNE RECENZIJE}





\title{
STROKOVNA RECENZIJA
}

\author{
VLADO DIMOVSKI
}

\section{Splošni del recenzije}

Zaprošen sem bil, da izdelam recenzijo knjige Poslovno komuniciranje avtorja Marka Ferjana. V pregled sem dobil golo besedilo knjige $\mathrm{v}$ formatu »word« in tehnično oblikovano postavitev knjige Univerzitetne založbe Univerze v Mariboru.

Knjiga je strukturirano na poglavja:

- Predgovor

- Teoretične osnove komuniciranja

- Stopnje razvoja organizacij

- Komuniciranje percepcijskih organizacij

- Zaposleni in management

- Spletno komuniciranje organizacij

- Marketinško komuniciranje

- Odnosi z javnostmi

- Krizno komuniciranje

- Pogajanja

- Lobiranje

- Literatura

- Elektronski viri

Seznam literature obsega 193 bibliografskih enote in 24 elektronskih virov.

Vsebina knjige se nanaša na področje poslovnega komuniciranja.

$\mathrm{V}$ uvodnem poglavju je avtor pojasnil teoretične osnove komuniciranja. Izhajal je iz S-R (»stimulus-response«) teorije zaznavanja in percepcije.

Avtor je nato opisal razvoj petih tipov podjetij: proizvodnega podjetja, prodajnega podjetja, trženjsko (marketinško) naravnanega podjetja, družbeno koristnega podjetja in percepcijskega podjetja.

$\mathrm{V}$ nadaljevanju je avtor obravnaval pojavne oblike poslovnega komuniciranja: medosebno komuniciranje zaposlenih in managementa $\mathrm{z}$ ljudmi iz okolja, spletno

NASLOv STROKOvega ReCEnzorJa: dr. Vlado Dimovski, redni profesor, Univerza v Ljubljani, Ekonomska fakulteta, Kardeljeva ploščad 17, 1000 Ljubljana, Slovenija, e-pošta: vlado.dimovski@ef.uni-lj.si. 
komuniciranje, marketinško komuniciranje, odnose z javnostmi, krizno komuniciranje, pogajanja in lobiranje. Opisal je razvoj posameznih pojavnih poslovnega komuniciranja od začetkov pa do danes, nato pa je predstavil najnovejša spoznanja.

\section{Posebni del recenzije}

Avtor knjige meni, da je bilo še pred desetletji za ljudi pomembno zgolj to, da so bili kot kupci zadovoljni s produkti in da so se organizacije prikazovale v lepi luči.

$\mathrm{Z}$ razvojem informacijsko komunikacijske tehnologije in $\mathrm{z}$ napredkom družbe pa so se stvari spremenile. Internet je ljudem omogočil dostop do najrazličnejših informacij, zmanjšala se je možnost nadzora nad mediji, posledično pa se je spremenila tudi kultura družbe.

$\mathrm{V}$ današnjem času ljudje zaznavajo vse, kar je povezano $\mathrm{z}$ organizacijami. Ljudje zaznavajo odnos podjetij do odjemalcev, do zaposlenih in odnos do celotnega okolja nasploh. Na podlagi zaznav se oblikujejo percepcije, kognicije in čustva, prihaja pa tudi do nastanka socialnih shem. Od vsega tega pa je odvisno obnašanje ljudi.

Pri opisih pojavnih oblik poslovnega komuniciranja je avtor zato izhajal iz »percepcijskega podjetja« oziroma iz koncepta »identitete organizacije. Percepcijsko podjetje pri izvrševanju namena svojega obstoja sistematično upravlja s svojo identiteto, pri tem pa je v neprestanih interakcijah z okoljem.

Koncept identitete organizacije je področje študija v organizacijski teoriji, ki si prizadeva odgovoriti na vprašanje: »Kdo smo mi kot organizacija?«

Pri razvoju identitete organizacije treba odgovoriti na tri vprašanja:

- Katere so bistvene lastnosti organizacije?

- Katere lastnosti organizacijo ločujejo od drugih organizacij?

- V čem je organizacija skozi obdobje svojega obstoja bila unikatna?

Naloga poslovnega komuniciranja je, da ob upoštevanju namena obstoja organizacije in norm okolja zagotovi kontinuirano in uravnoteženo interakcijo med organizacijo in okoljem, da bi prišlo do medsebojne uskladitve. Organizacija se uskladi tako, da spreminja svojo identiteto.

Avtor je v knjigi izpostavil pomen dvosmernega simetričnega komuniciranja. Organizacija mora razumeti okolje, vendar tudi okolje mora razumeti organizacijo in njene omejitve.

\section{Zaključek in predlog recenzije}

Vsebina knjige je aktualna. Naslov knjige je ustrezen.

Vsebina poglavij sledi naslovom poglavij. 
Uporabljena literatura je aktualna. Način citiranja je ustrezen.

V knjigi je opazna tudi osebna nota avtorja. V knjigi so opisi avtorjevih spoznanj in rezultati lastnega raziskovalnega dela.

Univerzitetni založbi Univerze v Mariboru priporočam, da knjigo izda kot znanstveno monografijo. 
PoSLOVNO KOMUNICIRANJE

Strokovne recenzije 


\title{
STROKOVNA RECENZIJA
}

\author{
EVA JEREB
}

\section{Splošni del recenzije}

Tehnično urejeno besedilo publikacije obsega 314 strani.

Vključenih je 11 slik in 5 tabel.

Delo vključuje 10 glavnih poglavij, povzetek in literaturo.

Vsebina besedila se nanaša na področje poslovnega komuniciranja.

Publikacija sodi na področje znanstvene monografije.

Seznam literature obsega 193 bibliografskih enote in 24 elektronskih virov.

\section{Posebni del recenzije}

Naslov dela je ustrezen in skladen z vsebino.

Naslovi glavnih poglavij so sledeči in ustrezajo napovedani tematiki:

- Teoretične osnove komuniciranja

- Stopnje razvoja organizacij

- Komuniciranje percepcijskih organizacij

- Zaposleni in management

- Spletno komuniciranje organizacij

- Marketinško komuniciranje

- Odnosi z javnostmi

- Krizno komuniciranje

- Pogajanja

- Lobiranje

Slike in tabele so ustrezne in pojasnjujejo besedilo.

Uporabljen je ustrezen jezik in terminologija.

NASLOV STROKOVNE RECENZORKE: dr. Eva Jereb, redna profesorica, Univerza v Mariboru, Fakulteta za organizacijske vede, Kidričeva cesta 55A, 4000 Kranj, Slovenija, e-pošta: eva.jereb@fov.unimb.si. 
Delo je aktualno in dobro pokriva obravnavano področje poslovnega komuniciranja.

Avtor je uporabil zadostno število sodobnih in vsebinsko relevantnih bibliografskih enot ter ustrezno navajanje le teh sproti $\mathrm{v}$ tekstu.

\section{Zaključek in predlog recenzije}

Publikacija »Poslovno komuniciranje« je izvirno delo, v katerem je avtor analiziral najnovejšo znanstveno literaturo in ugotovitve ter na osnovi lastnih raziskovalnih izsledkov in managerskih izkušenj predstavil nova spoznanja. Delo je namenjeno managerjem, študentom, kot tudi širšemu krogu bralcev. Avtor v delu predstavlja najsodobnejše izzive in smernice na področju poslovnega komuniciranja. V začetku dela pojasnjuje teoretične osnove komuniciranja. Za razumevanje celotnega konteksta poslovnega komuniciranja opiše sistem komuniciranja, pomen simbolov in način njihovega zaznavanja. Izhaja iz Shannonovega modela komuniciranja. Pri pojasnjevanju procesov na strani sprejemnika medosebnega komuniciranja avtor izhaja iz spoznanj nevro-znanosti. Pojasni principe zaznavanja, mehanizem nastanka percepcije kot »mentalne podobe« zaznanega, nastanek čustev kot odziv celotnega človekovega telesa na zaznave in proces kognicije. Da bi bralec razumel pomen poslovnega komuniciranja, je avtor opisal tudi stopnje razvoja organizacije: proizvodno, prodajno, marketinško, družbeno odgovorno in percepcijsko organizacijo. Avtor izhaja iz percepcijske organizacije oziroma iz koncepta identitete organizacije. Poslovno komuniciranje organizacije je potrebno za udejanjanje poslanstva in izvrševanje namena obstoja organizacije. Avtor meni, da namen obstoja organizacije vključuje: poslovni izid, rezultate, povezane $\mathrm{z}$ odjemalci, rezultate povezane $\mathrm{z}$ zaposlenimi in rezultate povezane $\mathrm{z}$ okoljem. Naloga funkcije poslovnega komuniciranja je, da zagotovi kontinuirano in uravnoteženo interakcijo med organizacijo in okoljem $\mathrm{z}$ namenom medsebojne uskladitve. Organizacija se usklajuje $\mathrm{z}$ okoljem tako, da razvija svojo identiteto. Uskladitev organizacije $\mathrm{z}$ okoljem se kaže $\mathrm{v}$ zadovoljstvu odjemalcev in $\mathrm{v}$ ugledu organizacije. Poslovno komuniciranje organizacije avtor strukturira na medosebno komuniciranje zaposlenih in managementa, spletno komuniciranje organizacij, marketinško komuniciranje, odnose $\mathrm{z}$ javnostmi, krizno komuniciranje, pogajanja in lobiranje. Meni, da tako, kot pri človekovem komuniciranju sodeluje telo kot celota, tudi organizacija mora komunicirati kot celota. Omenjena vsebina dela je ustrezna, aktualna in pokriva v naslovu napovedano področje. Razdeljena je v smiselno zaokrožena poglavja in podpoglavja, ki pokrivajo napovedano vsebino.

Predloženo delo priporočam v objavo. 


\title{
STROKOVNA RECENZIJA
}

\author{
JANEZ STARE
}

\section{Splošni del recenzije}

V elektronski obliki $\mathrm{v}$ formatu Word sem $\mathrm{v}$ recenzijo dobil knjigo Poslovno komuniciranje. Avtor knjige je Marko Ferjan.

Gradivo je strukturirano na poglavja:

- Kazalo

- Zahvala

- Povzetek

- Teoretične osnove komuniciranja

- Stopnje razvoja organizacij

- Komuniciranje percepcijskih organizacij

- Zaposleni in management

- Spletno komuniciranje organizacij

- Marketinško komuniciranje

- Odnosi z javnostmi

- Krizno komuniciranje

- Pogajanja

- Lobiranje

- Literatura

- Elektronski viri

Vsebina besedila se nanaša na področje poslovnega komuniciranja. V uvodnem poglavju avtor pojasnjuje teoretične osnove komuniciranja. Izhaja iz S-R (»stimulus-response«) teorije zaznavanja in percepcije.

Vsebina glavnih poglavij se nanaša na posamezne pojavne oblike poslovnega komuniciranja. Avtor je $\mathrm{v}$ teh poglavjih najprej opisal razvoj posameznih pojavnih poslovnega komuniciranja od začetkov pa do danes, nato pa je predstavil najnovejša spoznanja.

NASLOV STROKOVEGa RECEnZORJA: dr. Janez Stare, izredni profesor, Univerza v Ljubljani, Fakulteta za upravo, Gosarjeva ulica 5, 1000 Ljubljana, Slovenija, e-pošta: dekan@fu.uni-lj.si. 


\section{Posebni del recenzije}

Poslovno komuniciranje je izmenjava sporočil med ljudmi znotraj in zunaj organizacije. Iz vsebine knjige je razvidno, da avtor zelo izpostavlja pomen dvosmernega simetričnega komuniciranja med organizacijo in okoljem. Izhaja iz stališča, da je naloga poslovnega komuniciranja, da ob upoštevanju namena obstoja organizacije in norm okolja zagotovi kontinuirano in uravnoteženo interakcijo med organizacijo in okoljem z namenom medsebojne uskladitve.

Avtor knjige zelo poudarja, da organizacija mora razumeti norme, omejitve, potrebe, želje in pričakovanja okolja ter, da okolje organizacijo prepozna, da razume njeno poslanstvo in namen njenega obstoja ter tudi omejitve organizacije.

Avtor $\mathrm{v}$ knjigi obravnava naslednje pojavne oblike poslovnega komuniciranja: medosebno komuniciranje zaposlenih in managementa, spletno komuniciranje organizacij, marketinško komuniciranje, odnose z javnostmi, krizno komuniciranje, pogajanja in lobiranje. Posameznih pojavnih oblik poslovnega komuniciranja avtor ne obravnava medsebojno ločeno, pač pa kot splet elementov, ki skupaj tvorijo identiteto.

Organizacija se po mnenju avtorja z okoljem usklajuje tako, da razvija svojo identiteto. Za organizacijo v 21. stoletju ne zadošča, da kupci zaznajo zgolj atribute marketinga, ter da organizacija zgolj skrbi za dobro podobo v javnostih. Pomembno je, da okolje zazna vse atribute identitete organizacije. Po mnenju avtorja namen obstoja organizacije vključuje poslovni izid, vendar tudi rezultate, povezane $\mathrm{z}$ odjemalci, rezultate povezane $\mathrm{z}$ zaposlenimi in rezultate povezane $\mathrm{z}$ okoljem.

Uskladitev organizacije $\mathrm{z}$ okoljem se kaže $\mathrm{v}$ zadovoljstvu odjemalcev in $\mathrm{v}$ ugledu organizacije. Pri obravnavi poslovnega komuniciranja je avtor torej izhajal iz koncepta identitete organizacije, ki je področje študija v organizacijski teoriji. Poudarja pa, da tudi okolje mora razumeti omejitve organizacije. $\mathrm{V}$ tem kontekstu opisuje tudi pogajanja in lobiranje.

\section{Zaključek in predlog recenzije}

Knjiga vsebuje pregled in analizo temeljne ter tudi najnovejše znanstvene literature. Uporabljena literatura je aktualna. Način citiranja je ustrezen.

Iz vsebine knjige je razvidna osebna nota avtorja. Avtor je v knjigo vključil številna svoja spoznanja in izkušnje ter rezultate svojega raziskovalnega dela.

Vsebina knjige je aktualna. Naslov knjige je ustrezen.

Knjiga je strukturirana na poglavja in podpoglavja. Vsebina poglavij in podpoglavij ustreza obravnavni tematiki.

Avtor je uporabil splošno uveljavljene strokovne izraze. 
Knjigo priporočam v objavo kot znanstveno monografijo. 
